Prepared in cooperation with the West Virginia Department of Environmental Protection Division of Water and Waste Management, Water Use Section

\title{
Correlations of Daily Flows at Streamgages in and near West Virginia, 1930-2011, and Streamflow Characteristics Relevant to the Use of Index Streamgages
}

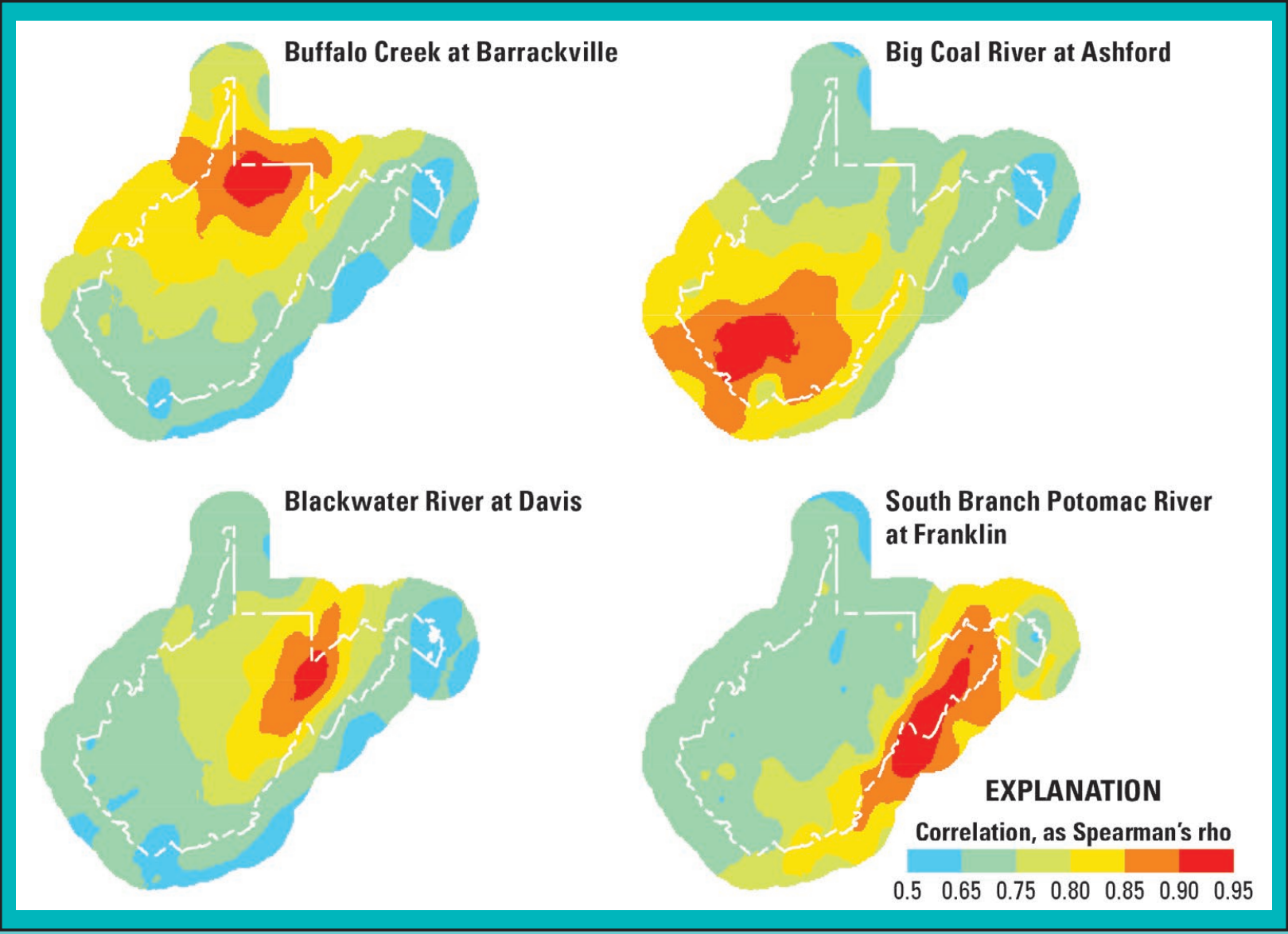

Scientific Investigations Report 2014-5061

Version 1.1, August 2014

U.S. Department of the Interior

U.S. Geological Survey 
Cover. Correlation of daily flows at unregulated streamgages with daily flows at four streams in West Virginia, as Spearman's rho, $1930-2011$. 


\section{Correlations of Daily Flows at Streamgages in and near West Virginia, 1930-2011, and Streamflow Characteristics Relevant to the Use of Index Streamgages}

By Terence Messinger and Katherine S. Paybins

Prepared in cooperation with the West Virginia Department of Environmental

Protection Division of Water and Waste Management, Water Use Section

Scientific Investigations Report 2014-5061

Version 1.1, August 2014 


\title{
U.S. Department of the Interior SALLY JEWELL, Secretary
}

\section{U.S. Geological Survey Suzette M. Kimball, Acting Director}

\author{
U.S. Geological Survey, Reston, Virginia: 2014 \\ First release: 2014 , online and in print \\ Revised: August 2014 (ver. 1.1)
}

\begin{abstract}
For more information on the USGS - the Federal source for science about the Earth, its natural and living resources, natural hazards, and the environment, visit http://Www.usgs.gov or call 1-888-ASK-USGS.

For an overview of USGS information products, including maps, imagery, and publications, visit $h t t p: / / W w w . u s g s . g o v / p u b p r o d$

To order this and other USGS information products, visit http://store.usgs.gov
\end{abstract}

Any use of trade, firm, or product names is for descriptive purposes only and does not imply endorsement by the U.S. Government.

Although this information product, for the most part, is in the public domain, it also may contain copyrighted materials as noted in the text. Permission to reproduce copyrighted items must be secured from the copyright owner.

Suggested citation:

Messinger, Terence, and Paybins, K.S., 2014, Correlations of daily flows at streamgages in and near West Virginia, 1930-2011, and streamflow characteristics relevant to the use of index streamgages (ver. 1.1, August 2014): U.S. Geological Survey Scientific Investigations Report 2014-5061, 83 p., . http://dx.doi.org/10.3133/sir20145061.

ISSN 2328-0328 (online) ISSN 2328-031X (print) 


\section{Contents}

Abstract

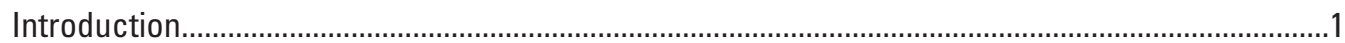

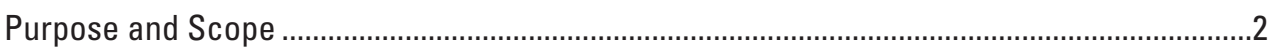

Description of Study Area ............................................................................................

The Streamgaging Network in West Virginia...........................................................................

History of the Streamgaging Network in West Virginia .........................................................

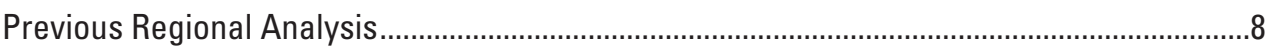

Previous Network Analyses for West Virginia .......................................................................

Previous Index-Streamgage Analysis ................................................................................

Streamflow and Basin Characteristics Relevant to the Use of Index Streamgages........................10

Effects of Basin and Channel Characteristics on Flow Timing .............................................15

Relation of Flow Duration, Timing, and Correlation to Hypothetical Seasonal and Annual

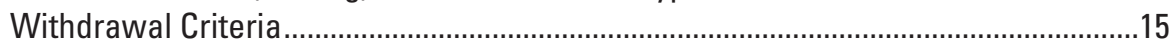

Correlation of Daily Flows at Streamgages ……..................................................................

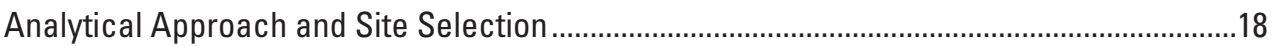

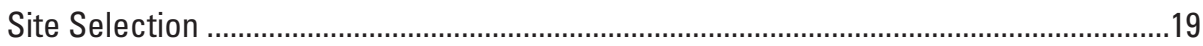

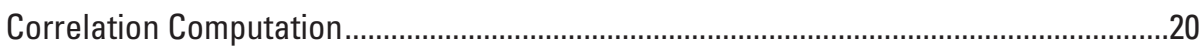

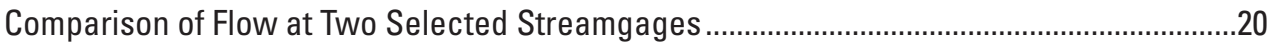

Relation of Correlation Coefficients to Flow Estimation ...........................................................22

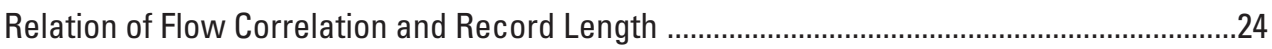

Relation between Flow Correlation and Distance....................................................................2

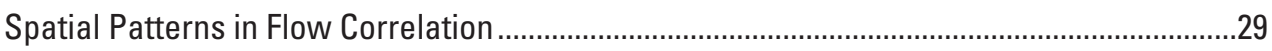

Seasonal Differences in Flow Correlation ..........................................................................

Decadal Differences in Flow Correlation.................................................................................

Map Correlation and Possible Expansion of the Present Streamgaging Network.................36

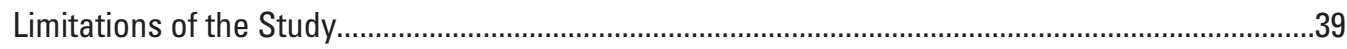

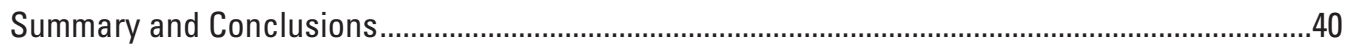

References Cited............................................................................................................... 4

Appendix 1. Flow correlation at all unregulated streamgages for full years,

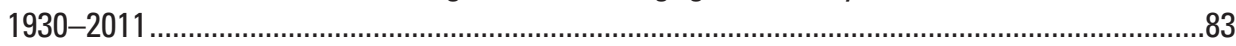

Appendix 2. Flow correlation at all unregulated streamgages for fall months only,

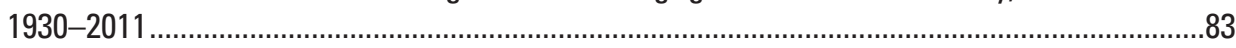

Appendix 3. Flow correlation at all unregulated streamgages for winter months only, 1930-2011

Appendix 4. Flow correlation at all unregulated streamgages for spring months only, 1930-2011

Appendix 5. Flow correlation at all unregulated streamgages for summer months only,

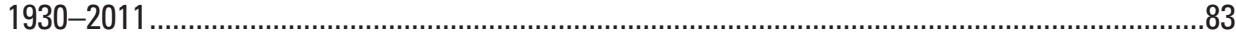

Appendix 6. Flow correlation at all unregulated streamgages for full years, 1963-1969 ...............83

Appendix 7. Flow correlation at all unregulated streamgages for full years, 1970-1979 ...............83

Appendix 8. Flow correlation at all unregulated streamgages for full years, 1992-2011 ...............83 


\section{Figures}

1. Maps showing $A$, selected towns, other locations, rivers, and major river basins in and near West Virginia, and $B$, physiography in and near West Virginia .....................3

2. Map showing elevation and mean annual precipitation in West Virginia, 1981-2010......4

3. Graph showing thirty-year normal monthly precipitation by physiographic setting, in West Virginia, 1981-2010.

4. Maps showing $A$, Thickness of the Marcellus Shale and horizontal gas wells completed in the Marcellus Shale, and $B$, all Marcellus Shale gas wells and the extent of the Utica Shale and gas-bearing Devonian siltstone formations in West Virginia

5. Map showing coal mine permit boundaries in West Virginia .8

6. Graph showing number of streamgages operated on unregulated streams in or within 50 miles of West Virginia, 1877-2011

7. Graphs showing flow duration of selected pairs of small and large streams with streamgages that are near each other.....

8. Map showing West Virginia Department of Environmental Protection WaterWithdrawal Guidance Tool map zones, 1981-2010 mean annual precipitation, and streamgages on unregulated streams in and near West Virginia

9. Graphs showing timing of rises and recessions of flow at $A$, Waites Run near Wardensville and Cacapon River near Great Cacapon, 2008, and B, Blackwater River at Davis and Dry Fork at Hendricks, 2011, in West Virginia

10. Graph showing daily flow and annual and seasonal 75-percent flow durations at Sand Run near Buckhannon, West Virginia, water years 2006-2010.

11. Annual and seasonal hydrographs, and scatterplots of daily flow at Dunkard Creek at Shannopin, Pennsylvania, in relation to Buffalo Creek at Barrackville, West Virginia, water year 2009.

12. Graphs showing proportion of days when flow at one site of a pair exceeded the $A, \mathrm{D} 75, B, \mathrm{D} 60$, and $C, \mathrm{D} 50$ and flow at the other site was less than the $\mathrm{D} 75$ in relation to Spearman's rho correlation coefficient for daily flows with line of regression and confidence interval for 15 selected streamgages in West Virginia, 1930-2011

13. Graphs showing relation of flow correlation for $A, 2$-year, $B, 5$-year, and $C, 10$-year subsets to flow correlation for the entire period of record for 15 selected streamgages in West Virginia, 1930-2011

14. Graph showing relation of distance between basin centroids to correlation coefficients of daily flow for pairs of streamgages in and near West Virginia, 1930-2011, with regression lines for the 99th, 50th, and 1st quantiles

15. Graph showing relation of distance between basin centroids to correlation coefficients of daily flow for pairs of streamgages with more than 40 years of record to pairs of streamgages with fewer than 2 years of record in and near West Virginia, 1930-2011, with regression lines for the 99th, 50th, and 1st quantiles.

16. Graphs showing relation of distance between basin centroids to correlation of daily flows among streamgages, with 10 or more years of concurrent records, on unregulated streams in the $A$, Atlantic Slope Basin, $B$, the Ohio River Basin, and $C$, one streamgage each in the Atlantic Slope and Ohio River Basins, in and near West Virginia, 1930-2011, and linear and 99th, 50th, and 1st quantile lines of regression 
17. Map showing correlation of daily flows at unregulated streamgages with daily flows at Buffalo Creek at Barrackville, West Virginia, as Spearman's rho, 1930-2011 ............30

18. Map showing correlation of daily flows at unregulated streamgages with daily flows at Big Coal River at Ashford, West Virginia, as Spearman's rho, 1930-2011 ...................30

19. Map showing correlation of daily flows at unregulated streamgages with daily flows at Blackwater River at Davis, West Virginia, as Spearman's rho, 1930-2011.................30

20. Map showing correlation of daily flows at unregulated streamgages with daily flows at South Branch Potomac River at Franklin, West Virginia, as Spearman's rho, 1930-2011

21. Map showing number of streamgages active in and near West Virginia during 2012 that correlated at Spearman's rho greater than 0.95 for daily flows during water years 1930-2011

22. Map showing number of streamgages active in and near West Virginia during 2012 that correlated at Spearman's rho greater than 0.90 for daily flows during water years 1930-2011

23. Map showing number of streamgages active in and near West Virginia during 2012 that correlated at Spearman's rho greater than 0.85 for daily flows during water years 1930-2011

24. Map showing number of streamgages active in and near West Virginia during 2012 that correlated at Spearman's rho greater than 0.90 for daily flows during fall months only, water years 1930-2011

25. Map showing number of streamgages active in and near West Virginia during 2012 that correlated at Spearman's rho greater than 0.90 for daily flows during winter months only, water years 1930-2011

26. Map showing number of streamgages active in and near West Virginia during 2012 that correlated at Spearman's rho greater than 0.90 for daily flows during spring months only, water years 1930-2011

27. Map showing number of streamgages active in and near West Virginia during 2012 that correlated at Spearman's rho greater than 0.90 for daily flows during summer months only, water years 1930-2011

28. Graphs showing relation of correlation coefficients of daily flow for the full year to that of $A$, fall, $B$, winter, $C$, spring, and $D$, summer at 391 selected streamgages in and near West Virginia, 1930-2011.

29. Map showing correlation of daily flows at unregulated streamgages with daily flows at Middle Island Creek at Little, West Virginia, as Spearman's rho, water years 1963-1969...

30. Map showing correlation of daily flows at unregulated streamgages with daily flows at Middle Island Creek at Little, West Virginia, as Spearman's rho, water years 1970-1979...

31. Map showing correlation of daily flows at unregulated streamgages with daily flows at Middle Island Creek at Little, West Virginia, as Spearman's rho, water years 1992-2011

32. Map showing number of streamgages active in and near West Virginia during 1963-1969 that correlated at Spearman's rho greater than 0.95 for daily flows during water years 1963-1969

33. Map showing number of streamgages active in and near West Virginia during 1970-1979 that correlated at Spearman's rho greater than 0.90 for daily flows during water years 1970-1979 
34. Map showing number of streamgages active in and near West Virginia during 1992-2011 that correlated at Spearman's rho greater than 0.90 for daily flows during water years 1992-2011

35. Map showing number of streamgages active in and near West Virginia during 2012 that correlated at Spearman's rho greater than 0.90 for daily flows during water years 1930-2011, historic correlation to two discontinued streamgages, and horizontal Marcellus Shale gas well completed through 2012

\section{Tables}

1. Description of unregulated streamgages in and near West Virginia, 1930-2011, and their coordinates, drainage areas, sources of basin centroid, regulation status, and length of record.

2. Number of times that instantaneous annual peak and annual daily minimum flow were recorded, by month, at 45 selected streamgages in and near West Virginia, 1930-2011

3. Annual water yield, drainage area, and mean annual precipitation for selected pairs of nested streamgages, 2006-2010.

4. Water-withdrawal tool map zones and associated index streamgages, and minimum, maximum, and mean annual precipitation, 1981-2010

5. Number of days exceeding the annual 75-percent flow duration for 15 selected streamgages in West Virginia, 1930-2011, and their average as a proportion

6. Number of days exceeding the relevant seasonal 75-percent flow duration at 15 selected streamgages in West Virginia, by season, water years 1930-2011, and their average as a proportion.

7. Maximum number of days between flows exceeding the annual 75-percent flow duration at 15 selected streamgages in West Virginia, water years 1930-2011.

8. Maximum number of days between flows exceeding the seasonal 75-percent flow duration at 15 selected streamgages in West Virginia, water years, 1930-2011 .............78

9. ArcGIS method report giving kriging parameters used to develop correlation maps ....19

10. Spearman's rho correlation coefficients for daily flow for unregulated streamgages within 50 miles of West Virginia and active during 1930-2011 available online

11. Number of concurrent days of flow record from full years for pairs of unregulated streamgages within 50 miles of West Virginia and active during 1930-2011 available online

12. Statistical significance of selected pairs of correlation coefficients at selected numbers of observations.

13. Average number of days when flow at one streamgage of a pair exceeded the indicated flow-duration interval, but flow at the other streamgage did not exceed the 75-percent flow duration, and Spearman's rho correlation coefficients for daily flow at 15 selected streamgages in West Virginia, 1930-2011...

14. Regression equations and diagnostics relating incorrect estimation of the 75-percent flow duration value at three selected index flows to correlation of daily flows for 15 selected streamgages in West Virginia, 1930-2011

15. Quantile regression equations and standard errors for the 25th, 50th, 75th, and 99th quantiles of the relation between distance and Spearman's rho correlation coefficient among pairs of streamgages for the Atlantic Slope and Ohio River Basins in and near West Virginia, 1930-2011. 
16. Spearman's rho correlation coefficients for daily flow during fall months only for unregulated streamgages within 50 miles of West Virginia and active during 1930-2011 available online

17. Spearman's rho correlation coefficients for daily flow during winter months only for unregulated streamgages within 50 miles of West Virginia and active during 1930-2011 available online

18. Spearman's rho correlation coefficients for daily flow during spring months only for unregulated streamgages within 50 miles of West Virginia and active during 1930-2011 available online

19. Spearman's rho correlation coefficients for daily flow during summer months only for unregulated streamgages within 50 miles of West Virginia and active during 1930-2011 available online

20. Spearman's rho correlation coefficients for daily flow for streamgages within 50 miles of West Virginia and active during 1963-1969 available online

21. Spearman's rho correlation coefficients for daily flow for streamgages within 50 miles of West Virginia and active during 1970-1979. available online

22. Spearman's rho correlation coefficients for daily flow for streamgages within 50 miles of West Virginia and active as of September 30, 2011 available online 


\section{Conversion Factors, Acronyms, and Abbreviations}

\begin{tabular}{|c|c|c|}
\hline Multiply & By & To obtain \\
\hline \multicolumn{3}{|c|}{ Length } \\
\hline inch (in.) & 2.54 & centimeter $(\mathrm{cm})$ \\
\hline inch (in.) & 25.4 & millimeter (mm) \\
\hline foot (ft) & 0.3048 & meter $(\mathrm{m})$ \\
\hline mile (mi) & 1.609 & kilometer $(\mathrm{km})$ \\
\hline \multicolumn{3}{|c|}{ Area } \\
\hline acre & 4,047 & square meter $\left(\mathrm{m}^{2}\right)$ \\
\hline square foot $\left(\mathrm{ft}^{2}\right)$ & 0.09290 & square meter $\left(\mathrm{m}^{2}\right)$ \\
\hline square mile $\left(\mathrm{mi}^{2}\right)$ & 2.590 & square kilometer $\left(\mathrm{km}^{2}\right)$ \\
\hline \multicolumn{3}{|c|}{ Volume } \\
\hline gallon (gal) & 3.785 & liter $(\mathrm{L})$ \\
\hline gallon (gal) & 0.003785 & cubic meter $\left(\mathrm{m}^{3}\right)$ \\
\hline cubic foot $\left(\mathrm{ft}^{3}\right)$ & 0.02832 & cubic meter $\left(\mathrm{m}^{3}\right)$ \\
\hline \multicolumn{3}{|c|}{ Flow rate } \\
\hline cubic foot per second $\left(\mathrm{ft}^{3} / \mathrm{s}\right)$ & 0.02832 & cubic meter per second $\left(\mathrm{m}^{3} / \mathrm{s}\right)$ \\
\hline \multicolumn{3}{|c|}{ Mass } \\
\hline pound, avoirdupois (lb) & 0.4536 & kilogram $(\mathrm{kg})$ \\
\hline
\end{tabular}

Vertical coordinate information is referenced to the North American Vertical Datum of 1988 (NAVD 88).

Horizontal coordinate information is referenced to the North American Datum of 1983 (NAD 83).

Elevation, as used in this report, refers to distance above the vertical datum. A water year is defined as the 12-month period from October 1 of any given year through September 30 of the following year. The water year is designated by the calendar year in which it ends and which includes 9 of the 12 months. 


\title{
Correlations of Daily Flows at Streamgages in and near West Virginia, 1930-2011, and Streamflow Characteristics Relevant to the Use of Index Streamgages
}

\author{
By Terence Messinger and Katherine S. Paybins
}

\section{Abstract}

Correlation of flows at pairs of streamgages were evaluated using a Spearman's rho correlation coefficient to better identify gages that can be used as index gages to estimate daily flow at ungaged stream sites in West Virginia. Much of West Virginia (77 percent) is within areas where Spearman's rho for daily streamflow between streamgages on unregulated streams (unregulated streamgages) is greater than 0.9; most withdrawals from ungaged streams for shale gas well hydraulic fracturing are being made in these areas. Most of West Virginia ( $>99$ percent) is within zones where Spearman's rho between streamgages on unregulated streams is greater than 0.85. Withdrawals for hydraulic fracturing are made from ungaged streams in areas where Spearman's rho between streamgages on unregulated streams is less than 0.9 , but because spatial correlation is partly a function of the density of the streamgaging network, adding or reactivating several streamgages would be likely to result in correlations of 0.90 or higher in these areas.

Seasonal differences in the strength and spatial extent of correlations of daily streamflows are great. The strongest correlations among streamgages are for fall, followed by spring, then winter. One possible explanation for the weak correlations for summer may be that precipitation and runoff associated with convective storms affect one basin and miss nearby basins. A comparison of correlation patterns during previously identified climatic periods shows that the strongest correlations occurred during 1963-69, a period of drought, and the weakest during 1970-79, a wet period. The apparent effect of frequent rain during 1970-79 overshadowed streamgagenetwork density, which was at its historic maximum in West Virginia at that time, so that the extent of areas with high correlation to at least one streamgage was smaller during 1970-79 than during 1963-69. Correlations for 1992 to 2011 were slightly weaker than those for 1963 to 1969 .

The relation between correlation and distance between basin centroids was determined to be stronger for streamgage pairs in the Ohio River Basin than for pairs in the Atlantic
Slope River Basins, which in turn was stronger than the relation between pairs of streamgages split between the two major basins. Quantile regression equations were developed for these three comparisons to estimate the Spearman's rho correlation coefficient for streamgage pairs using distance between basin centroids as a predictor variable. The equations can be used for streamgage network planning. For the Ohio River Basin, the distance between basin centroids at which 50 percent of streamgage pairs would exceed a Spearman's rho of 0.95 is 9 miles. The distance between basin centroids at which 50 percent of streamgage pairs would exceed a Spearman's rho of 0.90 is 25 miles, and the distance at which 50 percent of streamgage pairs would exceed a Spearman's rho of 0.85 is 48 miles. For the Atlantic Slope River Basins, the distance between basin centroids at which 50 percent of streamgage pairs would exceed a Spearman's rho of 0.95 is 1 mile. The distance between basin centroids at which 50 percent of streamgage pairs would exceed a Spearman's rho of 0.90 is 13 miles, and the distance at which 50 percent of streamgage pairs would exceed a Spearman's rho of 0.85 is 41 miles. For pairs of streamgages split between the two major basins, the regression equation gives a value of 0.84 for the correlation coefficient at zero miles. On maps of correlations, the shape of strongly correlated areas for streamgages in the Ohio River Basin is generally round. In the Valley and Ridge Physiographic Province, which generally coincides with the Atlantic Slope River Basins within the study area, areas strongly correlated with streamgages generally coincide with major valleys.

\section{Introduction}

West Virginia has traditionally enjoyed an abundant supply of, and a fairly moderate demand for, water. Statewide water demand has remained generally consistent (Carr, 2013). However, localized water demands, especially from small streams, increased when the development of horizontal drilling and hydraulic fracturing led to the development of the Marcellus Shale gas field beginning about 2007. Hydraulic 
fracturing of a horizontal well in the Marcellus Shale requires large amounts of water. Typically, about 1 to 5 million gallons of water are used for each horizontal well, although the amount of water varies in relation to factors such as the length of the well and the condition and composition of the rock to be fractured.

The natural gas industry differs from municipal water suppliers, the electrical generation industry, and other major water users in the region in that water demands are large but intermittent and widely dispersed. Shale gas wells are commonly developed long distances from large streams but close to small, ungaged streams. Natural gas production and management companies that had worked in the region prior to the development of hydraulic fracturing had long histories of obtaining the modest amounts of water needed for development or reclamation of conventional gas wells and well sites from nearby small streams. As the volume of water withdrawn from small, ungaged streams increased during development of the Marcellus Shale, concern grew that withdrawals could adversely affect aquatic life, and so the West Virginia Department of Environmental Protection (WVDEP) developed first voluntary guidance and then permitting requirements under an emergency rule. The Natural Gas Horizontal Well Control Act, enacted by the West Virginia Legislature in 2011, required WVDEP to review Water Management Plans that include the source of water to be used for hydraulic fracturing.

The initial voluntary guidance was based on use of an online Water-Withdrawal Guidance Tool (WWGT; West Virginia Department of Environmental Protection, 2013c; http:// www.dep.wv.gov/WWE/wateruse/Pages/WaterWithdrawal. aspx). Criteria were established to identify flow conditions under which withdrawals would be appropriate. Map zones were developed that referred to real-time index streamgages in the U.S. Geological Survey (USGS) streamgaging network, and potential water users were advised by the tool if streams in that zone, on that day, were expected to be too low to support water withdrawals.

The WWGT uses all active streamgages on unregulated streams (referred to in this report as "unregulated streamgages") to refer to map zones that were delineated using best professional judgment, principally considering regulation status, location and drainage area (M.I. Stratton, West Virginia Department of Environmental Protection, oral commun., 2010). Only unregulated streams are used for index streamgages, although information from streamgages on regulated streams is used to issue guidance for regulated stream reaches. The smallest streams available were preferred for the WWGT because flows (or more precisely, a proportion of mean annual flow) were to be estimated using a drainage-area ratio for the index streamgage to the ungaged site. A principal concern was that small streams typically rise and recede more quickly than large streams.

The WWGT is a convenient web-based tool that can be used to obtain streamflow information for ungaged stream sites using streamflow data from index streamgages.
However, the streamgaging network in and near West Virginia has not been specifically designed for the purpose of estimating near real-time flow at ungaged stream sites. Currently, little information is available on when and where in West Virginia flows on ungaged streams could reasonably be estimated in near-real time on the basis of flow conditions at index streamgages. Coverage of index streamgages could presumably be improved by expanding the streamgaging network, but the number and locations of the additional streamgages would be required data for determining whether that expansion was more cost-effective than other available methods of obtaining flow information needed to assess water withdrawals.

To obtain this information, the USGS, in cooperation with the WVDEP Division of Water and Waste Management, assessed conventional and map correlations among streamgages. Spatial patterns of correlation of daily flows at paired streamgages have been determined, as have seasonal and long-term differences in flow correlation at paired streamgages. Differences in long-term flow correlation result from the effects of climate variation, land-use change, and streamgaging network density.

\section{Purpose and Scope}

The purpose of this report is to provide additional insight for the selection of index gages to estimate near real-time daily streamflow at ungaged stream sites. Correlation analysis is used to assess the representativeness of the streamgaging network in and near West Virginia for making near-real-time estimates of flow at ungaged streams. Seasonal, long-term, and spatial variations in streamflow correlations among streamgages are discussed. Aspects of stream hydrology that are relevant to the use of index streamgages for estimating flows in real time are discussed. Correlations of daily flows in unregulated streams during water years 1930-2011 as Spearman's rho are shown in illustrations. Predicted correlations for various periods of record also are shown. Correlation coefficients of Spearman's rho are listed in tables.

\section{Description of Study Area}

Most of West Virginia is within the Appalachian Plateaus [19,960 square miles $\left.\left(\mathrm{mi}^{2}\right)\right]$ and Valley and Ridge $\left(4,220 \mathrm{mi}^{2}\right)$ Physiographic Provinces, although a small area $\left(20 \mathrm{mi}^{2}\right)$ at the easternmost tip of West Virginia is within the Blue Ridge Physiographic Province (fig. 1). The Appalachian Plateaus Physiographic Province is an area of flat-lying or gently folded rocks that formed when a peneplain was uplifted during the Appalachian Orogeny and then was dissected by stream erosion in the ensuing 300 million years (Fenneman, 1938). Elevation is highest in the east, where some peaks are higher than 4,000 ft (NAVD 88), and lowest in the west near the Ohio River, where the valley is lower than $600 \mathrm{ft}$ (fig. 2). Relief is generally greatest at highest elevations. Most of the Appalachian Plateaus Physiographic Province within West Virginia is 


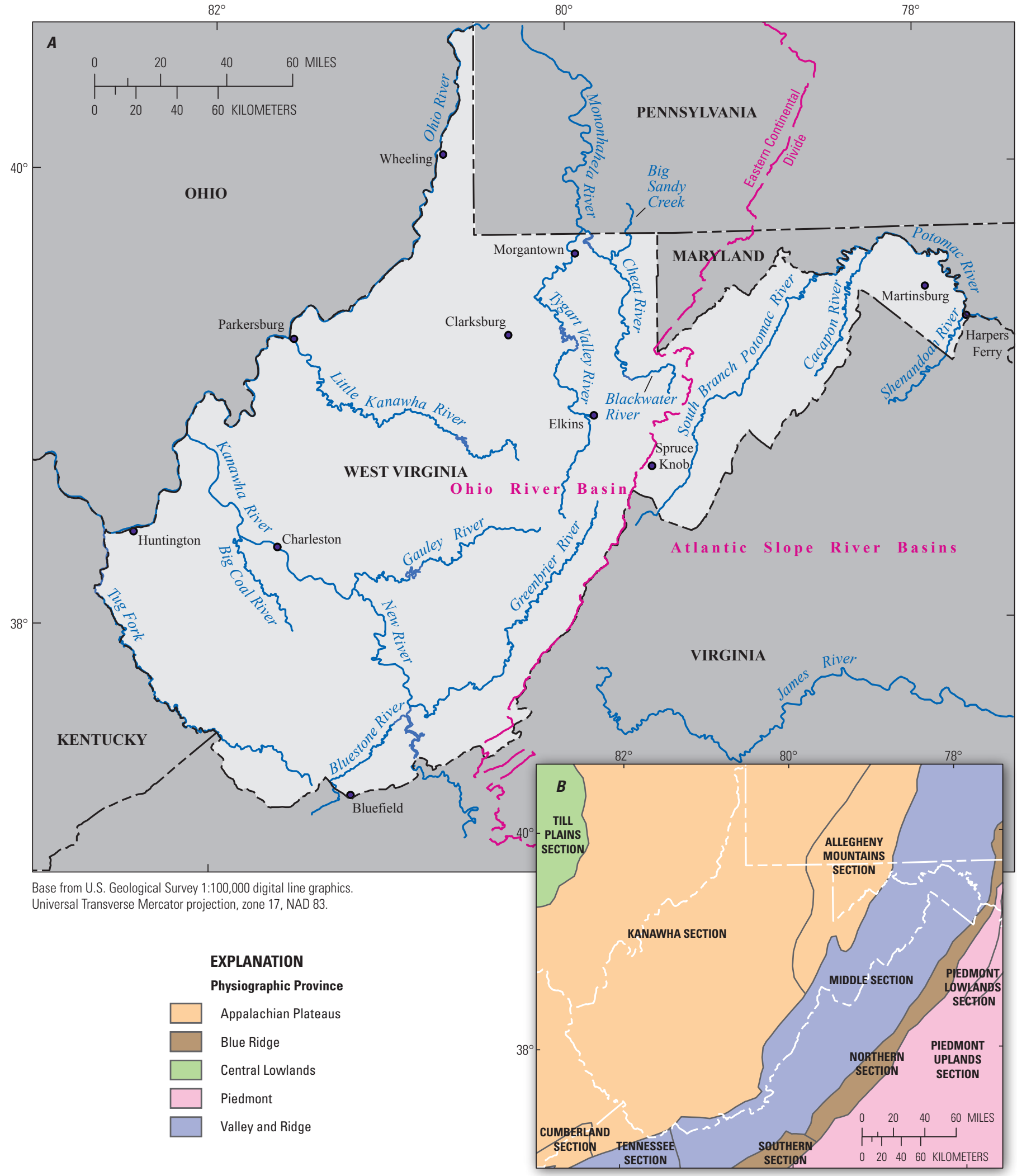

Figure 1. A, Selected towns, other locations, rivers, and major river basins in and near West Virginia, and $B$, physiography in and near West Virginia. 


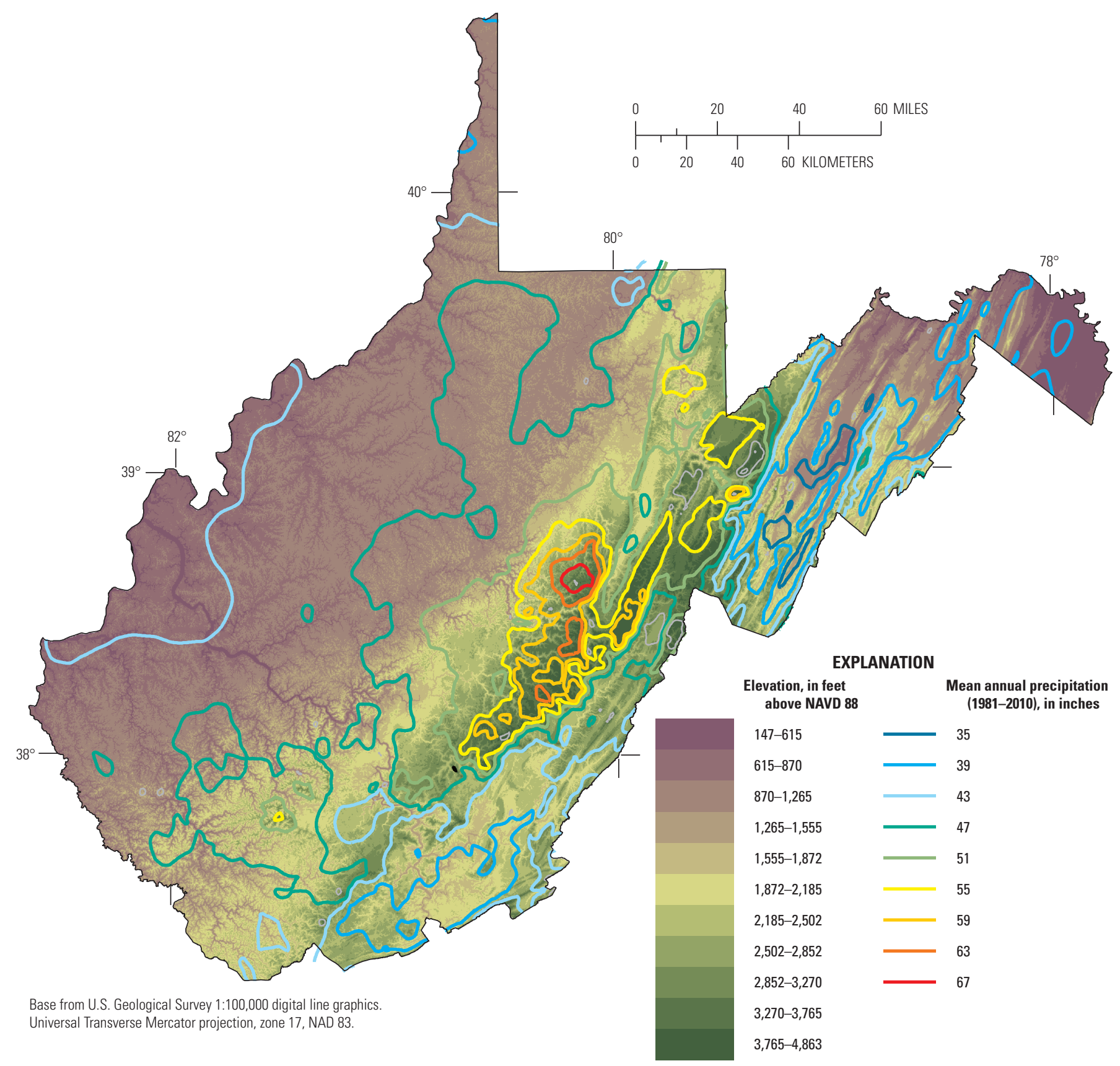

Figure 2. Elevation and mean annual precipitation in West Virginia, 1981-2010. 
drained by the Ohio River $\left(19,631 \mathrm{mi}^{2}\right)$, and the rest $\left(329 \mathrm{mi}^{2}\right)$ is drained by the Potomac River.

In West Virginia, the Valley and Ridge Physiographic Province consists of layers of folded and faulted sedimentary rocks that are of Mississippian age or older (Cardwell and others, 1968). Rocks of the Valley and Ridge province were folded in the Appalachian Orogeny, the same event that uplifted the Appalachian Plateaus. Linear ridges that run from southwest to northeast alternate with valleys. Ridges are generally underlain by harder, more erosion-resistant rock than the rock underlying the valleys. Streams in this province drain in a trellised pattern. Generally, lithology in the Valley and Ridge is more complex than in the Appalachian Plateaus. Some of the valleys, predominantly near the eastern edge of the province, are underlain by karst developed in limestone and dolomite rocks.

Mean annual precipitation and maximum storm precipitation are not closely correlated. Maximum storm precipitation, as measured by any of several frequencies for storm intensity, is greatest in the southern and eastern parts of the study area and least in the northern and western parts of the study area (Hydrometeorological Design Studies Center, 2006a, 2006b). The eastern part of West Virginia is more frequently affected by Atlantic Ocean hurricanes than is the west, which accounts, in part, for the difference. Mean annual precipitation ranged from about 35 to 67 inches during 1980-2010 (PRISM Climate Group, 2012). Distribution of mean annual precipitation is closely related to elevation, and the greatest annual precipitation is received in the highest parts of the study area. The lowest mean annual precipitation in West Virginia is in the Valley and Ridge province and the southern Greenbrier River Basin in the southeastern part of the study area, which are affected by a pronounced rain shadow, and in the Northern Panhandle (fig. 1, fig. 2).

Precipitation varies seasonally throughout the three principal physiographic regions in West Virginia (fig. 3). Maximum precipitation is received in all areas during May-July. Minimum precipitation is received in the Allegheny Mountain and the Kanawha (Unglaciated) sections of the Appalachian Plateaus in October, with only slightly more precipitation in February. In the Valley and Ridge, precipitation is generally low during October and December through February. Normal monthly precipitation in the Allegheny Mountain section in the study area is greater than in the Kanawha section and the Valley and Ridge province during every month of the year. Normal monthly precipitation in the Kanawha section of the Appalachian Plateaus exceeds that of the Valley and Ridge during every month except September, a month when the Valley and Ridge is sometimes affected by Atlantic Ocean hurricanes.

Land use, surface geology, and soils all vary with elevation within the study area (Messinger and Hughes, 2000). Generally, the highest population density and concentration of urban land is in river valleys in the northern and western parts and in the eastern tip of West Virginia. Commercial agriculture is limited in scope, and most commercial farms are near the

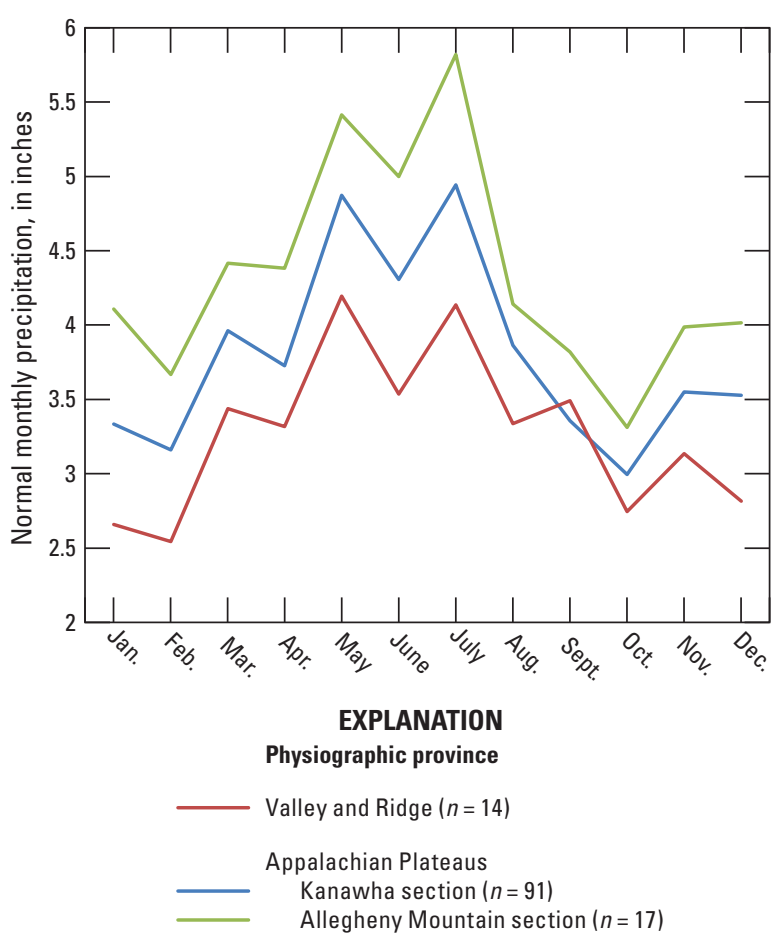

Figure 3. Thirty-year normal monthly precipitation by physiographic setting, in West Virginia, 1981-2010.

Ohio and Kanawha Rivers and throughout the Potomac and Greenbrier River Basins (fig. 1). Forest cover is most dense in the mountains in central West Virginia. The largest cities in the study area, all with populations less than 52,000, are Charleston, on the Kanawha River; Huntington, Parkersburg, and Wheeling, on the Ohio River; and Morgantown, on the Monongahela River (U.S. Census Bureau, 2009). Because the largest urban areas in the study area are in the valleys of major rivers, increases in peak storm runoff caused by impervious urban lands are generally localized and most pronounced on a few small streams.

Principal economic activities include coal mining, forestry, and oil and gas production, which are widespread throughout most of the study area; manufacturing, which is most common in areas near the Monongahela, Ohio, and Kanawha Rivers; and agriculture, which is most important commercially near the Ohio and Kanawha Rivers and in the Greenbrier River Basin (Messinger and Hughes, 2000). Of these, forestry is nearly ubiquitous throughout West Virginia, the exception being urban areas. Some activities associated with timber harvesting may have strong effects on storm hydrographs and peak flows but smaller effects on medium and low flows.

Oil and gas have been produced in West Virginia since 1859 (Eggleston, 1996). As of 2013, records exist for 55,000 active and 12,000 abandoned oil and gas wells, many of them decades old, in 53 of West Virginia's 55 counties (West Virginia Department of Environmental Protection, 2013a). 
Development of hydraulic fracturing and horizontal drilling technology led to extensive development of shale gas beginning about 2007, principally in the Marcellus Shale (fig. $4 A$; Soeder and Kappel, 2009). Shale gas wells that have been drilled to the Marcellus Shale in West Virginia include many vertical wells that were not hydraulically fractured; some of these wells were principally targeted at a different formation. Most horizontally drilled, hydraulically fractured wells in the Marcellus Shale are in northern West Virginia (fig. 4A). Horizontal wells have also been drilled in Devonian siltstone and shales, particularly in the Huron Member of the Ohio Shale (informally referred to as the Lower Huron), although because those wells are typically air-fractured, they require much less water than Marcellus Shale wells. The Utica Shale (fig. $4 B$ ), which underlies much of West Virginia and is being developed extensively in Ohio, has been the target for only one well in West Virginia through 2013 (West Virginia Department of Environmental Protection, 2013b).

Surface and underground coal mining are widespread throughout much of the study area (fig. 5). Coal mines alter flow in a complex way. Surface mines increase water yield and low and medium flows (Messinger and Paybins, 2003). Runoff from intense storms is increased by some, but not necessarily all, surface mines, although runoff from moderate storms, including long, sustained storms, is reduced (Messinger, 2003). Small basins and streams may either gain water from, or lose water to, underground mines, depending on the stratigraphic position of the mine relative to the stream or aquifer, dip of the bedrock, and other factors (Hobba, 1981; Kozar and others, 2013). In general, large streams (drainage area $>\sim 50 \mathrm{mi}^{2}$ ) underlain by underground coal mines usually have increased base flow and water yield compared to streams draining unmined areas.

\section{The Streamgaging Network in West Virginia}

The streamgaging network, both nationally and within West Virginia, was developed over decades to meet a variety of goals and serve multiple stakeholders. As technology, knowledge of hydrology, and societal priorities have changed, new uses for streamgages have emerged. The addition of streamgages to the network has largely been opportunistic, and the existing network represents the needs both of the USGS and of other stakeholders.

The goal of the USGS streamgaging program is to provide hydrologic information needed to define, use, and manage the Nation's water resources (Wahl and others, 1995). The program provides a continuous, well-documented, wellarchived, unbiased, and broad-based source of reliable and consistent water data. Streamflow information is used for flood warnings; current and short-term (days to months) operational decision making for withdrawals, hydropower production, and navigation; assessing and mitigating flood risks and determining floodplains; planning and designing water infrastructure; managing and improving water quality and assessing stream habitat; monitoring legal agreements on the allocation of water resources; recreational uses; and improving the scientific understanding of the environment and how it is changing over time (Bales and others, 2004). Streams that are important for water supply, flood warning, or other critical operational needs are directly gaged; these include most major rivers. For many smaller streams, streamflow information is provided in the form of regional equations for selected flow characteristics. To provide the information needed to develop, maintain, and refine these equations, streamgages are operated on small streams draining basins that represent larger areas. Understanding regional hydrology requires information on the variability of streamflow regionally, as well as over time. Because many critical streamflow events are infrequent, such as major droughts and floods, streams must be continuously gaged for long periods in order to reliably measure trends. Currently, streamflow is measured continuously at 85 stations. The maximum number of stations, 115, was operated in 1969 and 1977. Historic data, including that for discontinued stations, is critically important for developing regional equations, and streamgages with extended periods of record are among the most valuable because they provide baseline information for detecting future changes (National Hydrologic Warning Council, 2006).

\section{History of the Streamgaging Network in West Virginia}

The first streamgage in West Virginia, Kanawha River at Kanawha Falls (streamgage 03193000), was established in 1877 , and the second through fifth were established in 1895 (fig. 6). The streamgaging network was expanded to 47 streamgages by 1930, following the development of stripchart recorders that enabled collection of continuous-stage data. The number of streamgages operated in West Virginia has not dropped below 40 since 1930, and 15 streamgages have been in continuous or near-continuous operation on still-unregulated streams since the 1930s. To be useful for regional analysis, a streamgage must be on an unregulated stream. Among the unregulated streamgages lost for regional analysis since the 1930s are those on streams that became regulated, such as Kanawha River at Kanawha Falls in 1939, with the completion of Claytor Dam on the New River in Virginia. However, the unregulated period of record for such streamgages remains available for analysis and comparison with records from other unregulated streamgages that were operated contemporaneously.

The number of active unregulated streamgages operated in West Virginia increased to 77 in 1947, remained generally stable until 1968, and then increased to 94 . West Virginia had the greatest coverage of unregulated streams from 1968 through about 1980. Beginning in 1980, Federal program cuts, including the end of the Coal Hydrology Program, led to the 

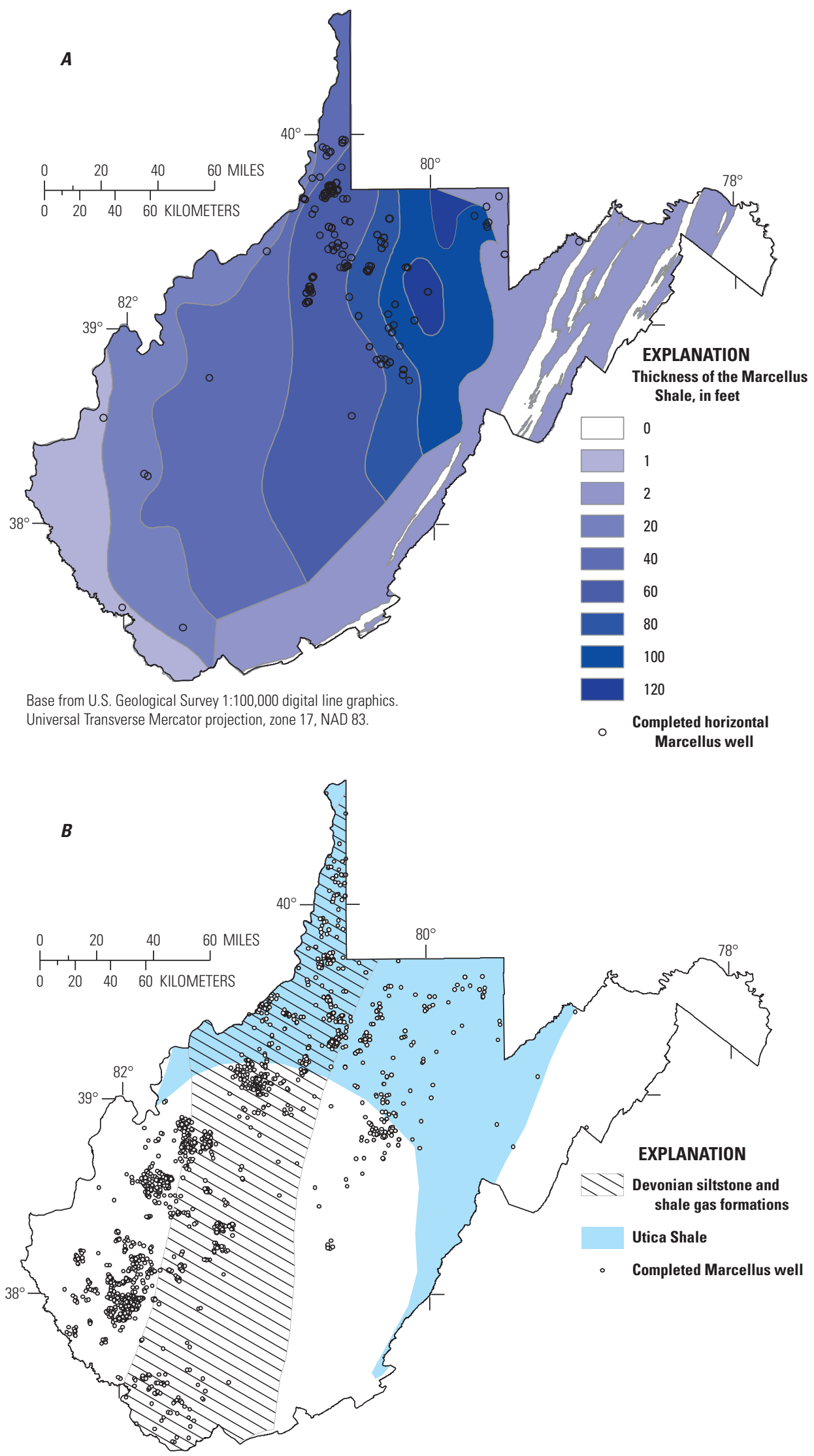

Base from U.S. Geological Survey 1:100,000 digital line graphics. Universal Transverse Mercator projection, zone 17, NAD 83.

Figure 4. A, Thickness of the Marcellus Shale and horizontal gas wells completed in the Marcellus Shale, and $B$, all Marcellus Shale gas wells and the extent of the Utica Shale and gas-bearing Devonian siltstone formations in West Virginia. 


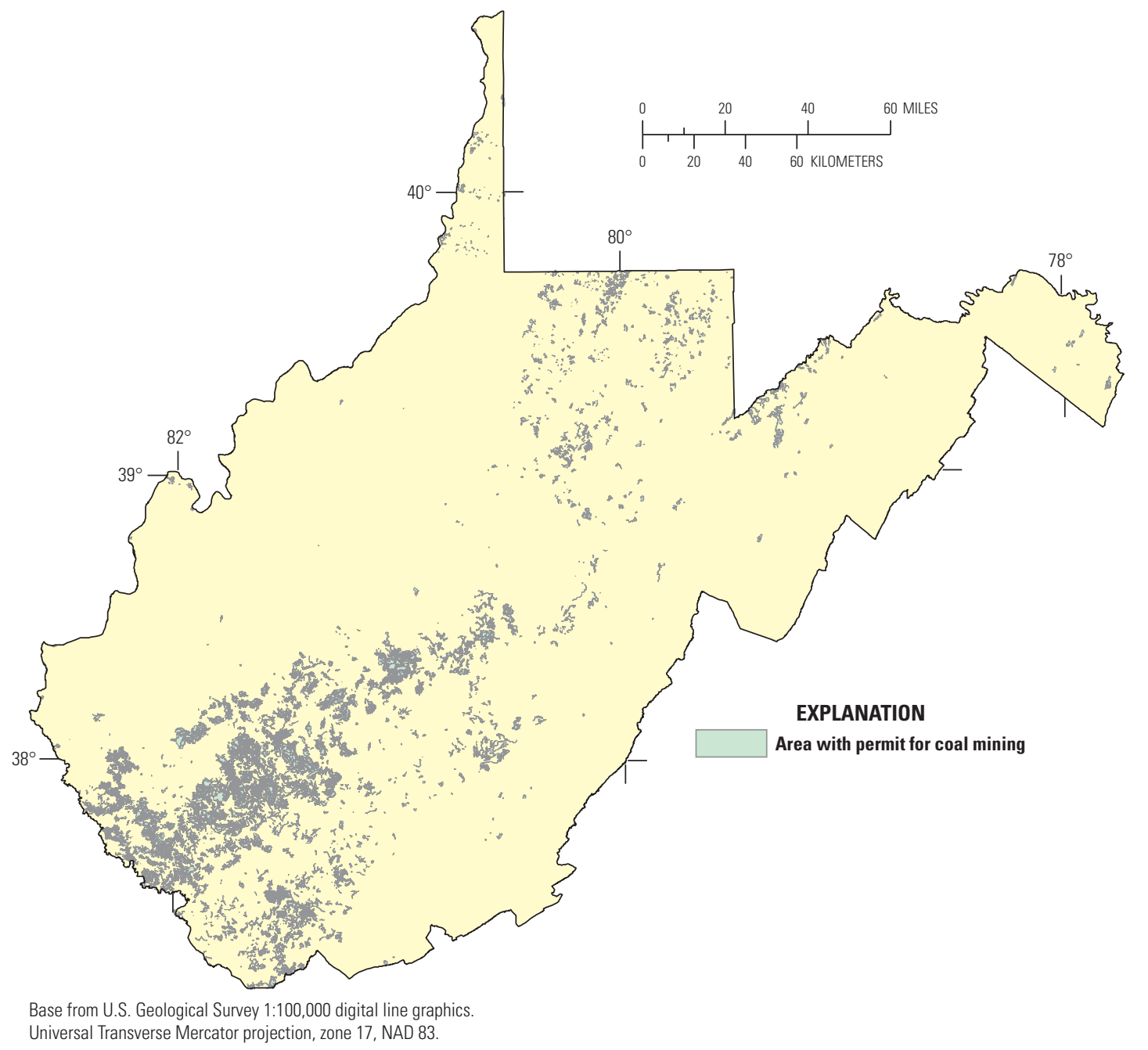

Figure 5. Coal mine permit boundaries in West Virginia.

loss of 41 unregulated streamgages in West Virginia by 1984. The number of unregulated streamgages fluctuated between 43 and 57 until 2003 and was fairly stable at about 60 unregulated streamgages between 2003 and 2010. Thirteen unregulated streamgages were added to West Virginia's network between 2011 and 2013, although not all are intended to be long-term streamgages.

\section{Previous Regional Analysis}

The USGS uses records from the streamgaging network to develop regional regression equations for selected flow characteristics. For many small streams, typical needs for streamflow information are satisfied by these regional equations. For West Virginia, regional equations have been developed for flood frequency discharges (Wiley and Atkins, 2010a), annual and seasonal low-flow statistics (Wiley, 2006; Wiley, 2008; Wiley and Atkins, 2010b), and bankfull channel characteristics (Wiley and others, 2002; Keaton and others,
2005; Messinger, 2009). To provide the information needed to develop and refine these equations as more data become available, streamgages are operated on small streams draining basins that represent larger areas.

Understanding regional hydrology requires information on the variability of streamflow over time, as well as spatially. Because many of the critical streamflow events are infrequent, such as major droughts and floods, streams must be continuously gaged for long periods in order to reliably define trends. Developing and refining regional equations is among the most important uses for streamgaging information, and insight gained from regional analyses is used to make decisions about the allocation of resources among potential streamgaging sites.

Of the various regional equations that have been developed for West Virginia, those pertaining to low-flow magnitude and frequency are the most relevant for managing water withdrawals. Equations have been published for a variety of statistics, including selected flow-duration quantiles (Wiley, 2008). For the equations, West Virginia was separated into 


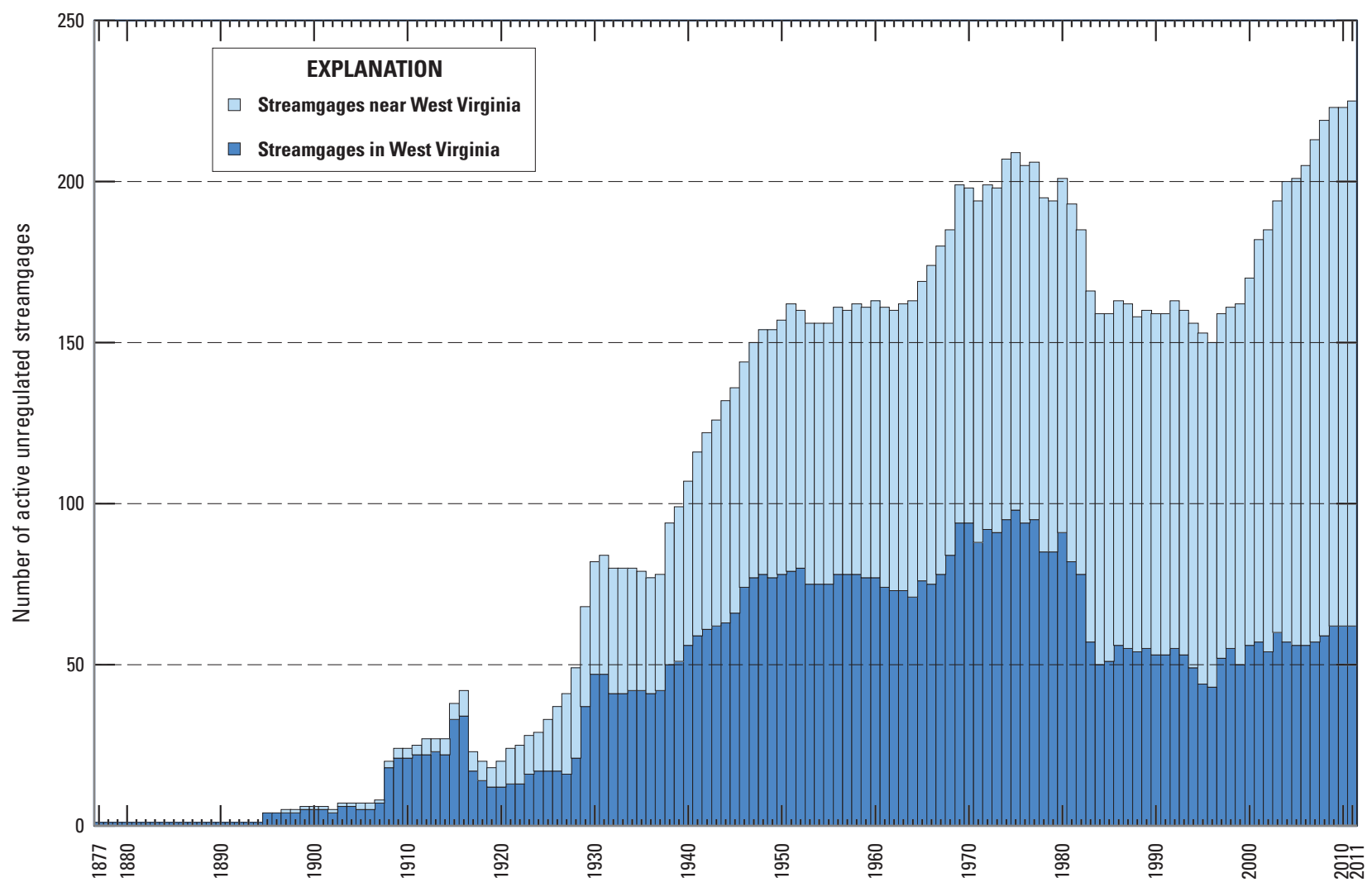

Figure 6. Number of streamgages operated on unregulated streams in or within 50 miles of West Virginia, 1877-2011.

three low-flow regions - North, South, and East. The East Region generally coincides with the part of West Virginia in the Valley and Ridge Physiographic Province and is separated from the North and South Regions by a boundary that is close, but not identical, to the rain shadow along the Allegheny Front.

The low-flow regional study evaluated patterns in the annual minimum daily mean flows and low-flow statistics for streamgages in or near West Virginia (Wiley, 2006). Five periods consisting of similar patterns in minimum flows between 1930 and 2002 were identified: 1930-1942, a period of drought; 1943-1962, which included both dry and wet years; 1963-1969, a period of drought; 1970-1979, a 10-year period when every year had an annual low-flow value greater than the long-term average; and 1980-2002, which included both wet and dry years. The period 1970-1979 is important for efforts to analyze historic flow records because it is the historic period with both the most extensive coverage of unregulated streamgages and the wettest period on record.

\section{Previous Network Analyses for West Virginia}

Several streamgaging network analyses have been performed since 1970. Frye and Runner (1970) analyzed the West Virginia streamgaging network when it was near its maximum number of stations and cuts to the program were anticipated. All streamgages were classified according to their purpose. Four categories were designated: gages operated (1) for current uses, such as managing day-to-day operations of a dam or another specific facility, (2) for planning and design or to provide statistical estimates of streamflow characteristics to be used on ungaged streams, (3) to determine long-term trends for 11 designated streams, and (4) to monitor stream environments or to describe the hydrologic environment of stream channels or drainage basins. Categories 2 and 4 seem to overlap; the principal difference is that specific analytical goals were set for category 2. For the planning and design category, eight statistics (mean annual flow, standard deviation of annual flow, mean monthly flow, standard deviation 
of monthly flow, 50-year flood, 7-day 2-year low flow, 7-day 20-year low flow, and 7-day 50-year high flow) and their accuracy goals were designated (standard errors of prediction equal to those achieved by 10 years of record on streams draining less than $500 \mathrm{mi}^{2}$ and 25 years of record on streams draining more than $500 \mathrm{mi}^{2}$ ).

Runner and others (1989) applied optimization algorithms for two goals, (1) to minimize the total error in estimating values for various streamflow characteristics for all streamgages then in operation in West Virginia, and (2) to reduce operational costs. The study is part of a series of studies intended to optimize the national streamgaging network. The study concluded that none of the 60 streamgages, including regulated streamgages, still in operation in 1985 could be discontinued without increasing total error. The principal consideration in minimizing total error was compensating for instrument failure at a time when few streamgages had telemetry and instrument failure shortly after a site was visited could result in weeks or months of lost record. The compensation principally took the form of providing enough redundancy in the network that missing records could be estimated effectively. Now that continuous streamgages in the West Virginia network are routinely equipped with telemetry so that instrument failure is known in near-real time, the risk of extensive lost record resulting from instrument failure has decreased greatly.

Straub (1998) evaluated the streamgaging network for effectiveness in providing regional flow information for Ohio. Regression equations were developed for selected streamflow characteristics. The contribution from each station to the predictive power of the equations was determined, and stations were ranked on the basis of a cost-weighted reduction of the mean square error associated with each equation. Typically, continuing data collection at unregulated streamgages with less than 11 years of record and drainage areas of less than $200 \mathrm{mi}^{2}$ contributed the largest cost-weighted reduction to the average sampling-error variance of the regional estimating equations. The greatest spatial gap was in southern Ohio, along the border with West Virginia, owing to sparse coverage of streamgages both in Ohio and nearby parts of West Virginia.

The various plans to redesign or streamline the streamgaging network for West Virginia have not been implemented. Of the 11 long-term trend stations recommended by Frye and Runner (1970), one became regulated in 1973, five were discontinued by 1984 , and one was discontinued in 1995. In contrast, 8 of the 15 streamgages that Frye and Runner (1970) indicated could be discontinued have remained in continuous operation through 2013. Runner and others (1989) identified a need for streamflow data for minor tributaries of the Ohio and Kanawha Rivers, a gap that Straub (1998) documented again and that remains unfilled in 2012. The failure to implement these plans resulted partly from technological, analytical, or environmental changes that made the recommendations obsolete and partly from changes in the manner that water data are used, which was difficult to anticipate.

\section{Previous Index-Streamgage Analysis}

Although index streamgages have long been used to estimate or infer flow conditions at ungaged streams, most systematic approaches to their use have traditionally concentrated on transferring flow statistics to ungaged sites (Stedinger and Thomas, 1985). In West Virginia, Wiley (2008) determined that, for ungaged locations on gaged streams, better estimates of low-flow statistics can be obtained for ungaged sites within specified ranges of drainage area by transferring the flow statistics to the ungaged site from a gaged site upstream or downstream by using a drainage-area ratio than by using regional equations. For low-flow statistics, the drainage-area ratio ranges from 0.5 to 2.0 for the drainage area of the streamgage, and for high-flow statistics, the drainage-area ratio ranges from 0.21 to 4.76 for the drainage area of the streamgage.

American Whitewater (2013) operates an Internet application intended for whitewater boaters that relates water levels of various streams that are deemed suitable for kayaking, canoeing, or rafting, to water levels at USGS streamgages (http://www.americanwhitewater.org/content/River/statesummary/state/WV/). Reaches of most streams of a stream order of 3 or more in West Virginia are described and related to an index gage. Volunteer commenters, including anonymous and pseudonymous commenters, have verified the relations between flow at streamgages and flow at many ungaged reaches. This application has limitations. Comments on and corrections to the stream descriptions for this application are informal. The number of comments is related to the popularity of the reach so that most discussion is of the most popular stream reaches among boaters. Little or no information is available for many streams of regulatory interest, especially for flatwater streams. The relations between favorable boating conditions on small streams and threshold conditions for withdrawal are likely to be imprecise. However, the application represents an extensive collection of observations on common relations between flows at index streamgages and those in ungaged streams made by interested, experienced observers.

\section{Streamflow and Basin Characteristics Relevant to the Use of Index Streamgages}

The WWGT was developed by WVDEP to allow potential water users to know whether a proposed water withdrawal was environmentally safe. The WWGT uses an index streamgage to estimate flow for an ungaged stream site. Flow estimates for ungaged sites that are derived from flow at index streamgages will always be imperfect. Understanding the differences in flow characteristics among sites is necessary to make the most of the streamflow data that are available. Nearly all flow characteristics are affected by the size of 
the basin, even when they are normalized by drainage area. Nearby large and small streams with basins having similar basin characteristics and the same weather patterns will have different flow characteristics, such as the magnitude, timing, and duration of flow.

Streamflow in and near West Virginia varies throughout the year. At the 45 long-term unregulated streamgages in and near West Virginia with continuous or nearly continuous daily record since 1930 (nearly continuous defined as fewer than 3 years of missing record; tables 1 (at end of report) and 2), the annual minimum daily flow was most frequently recorded in September and October. For more than 82 years, the annual minimum daily flow was recorded only 10 times in January, twice in February, and never during March, April, or May. Floods can occur during any month of the year. Instantaneous annual peaks have been recorded in every month, although substantially more have been recorded during January through April than during the rest of the year. Typically, the highest sustained flows occur during late winter or early spring, following the season of maximum recharge, and the lowest sustained flows occur during late summer and early fall.

Many differences in flow characteristics can be summarized using flow duration curves and unit flow (flow per unit drainage area; fig. 7). Even when flow is normalized by drainage area, the duration of flow differs between large and small basins. Flow-duration values representative of 1930 to 2002 were compared for three pairs of adjacent streamgages (Wiley, 2006). For all three pairs, unit flows for most or all of the flow-duration values were smaller for the small stream than for the nearby large stream; only one value of unit flow for the

Table 2. Number of times that instantaneous annual peak and annual daily minimum flow were recorded, by month, at 45 selected streamgages in and near West Virginia, 1930-2011.

[Annual peaks were computed by water year, October 1-September 30, and annual minima were computed by climatic year, April 1-March 31]

\begin{tabular}{|lcc|}
\hline Month & $\begin{array}{c}\text { Instantaneous } \\
\text { annual peak flow }\end{array}$ & $\begin{array}{c}\text { Annual daily } \\
\text { minimum flow }\end{array}$ \\
\hline January & 135 & 10 \\
\hline February & 150 & 2 \\
\hline March & 249 & 0 \\
\hline April & 140 & 0 \\
\hline May & 94 & 0 \\
\hline June & 69 & 35 \\
\hline July & 29 & 125 \\
\hline August & 40 & 312 \\
\hline September & 24 & 786 \\
\hline October & 60 & 639 \\
\hline November & 50 & 76 \\
\hline December & 103 & 32 \\
\hline
\end{tabular}

5-percent flow duration at one site, Panther Creek near Panther (streamgage 03213500), exceeded unit flow for the adjacent larger stream, Tug Fork at Litwar (streamgage 03213000).

Flow characteristics for six pairs of nested streamgages from 2006 to 2010 were evaluated. Drainage areas of the smaller stream of the pair ranged from 1.9 to 16 percent of the drainage area of the larger site (table 3). Although mean annual precipitation was clearly related to water yield (total annual flow normalized by drainage area), basin size or other characteristics also affected flow. Differences in flows between large and small streams within the same basin are not always consistent, especially when the basin is heterogeneous. Five of the six pairs of nested streamgages had a higher water yield at the upstream basin (smaller stream) than at the downstream basin (larger stream). In the Cheat River Basin, water yield from Shavers Fork near Cheat Bridge (streamgage 03067510; drainage area, $60.2 \mathrm{mi}^{2}$ ) slightly exceeded water

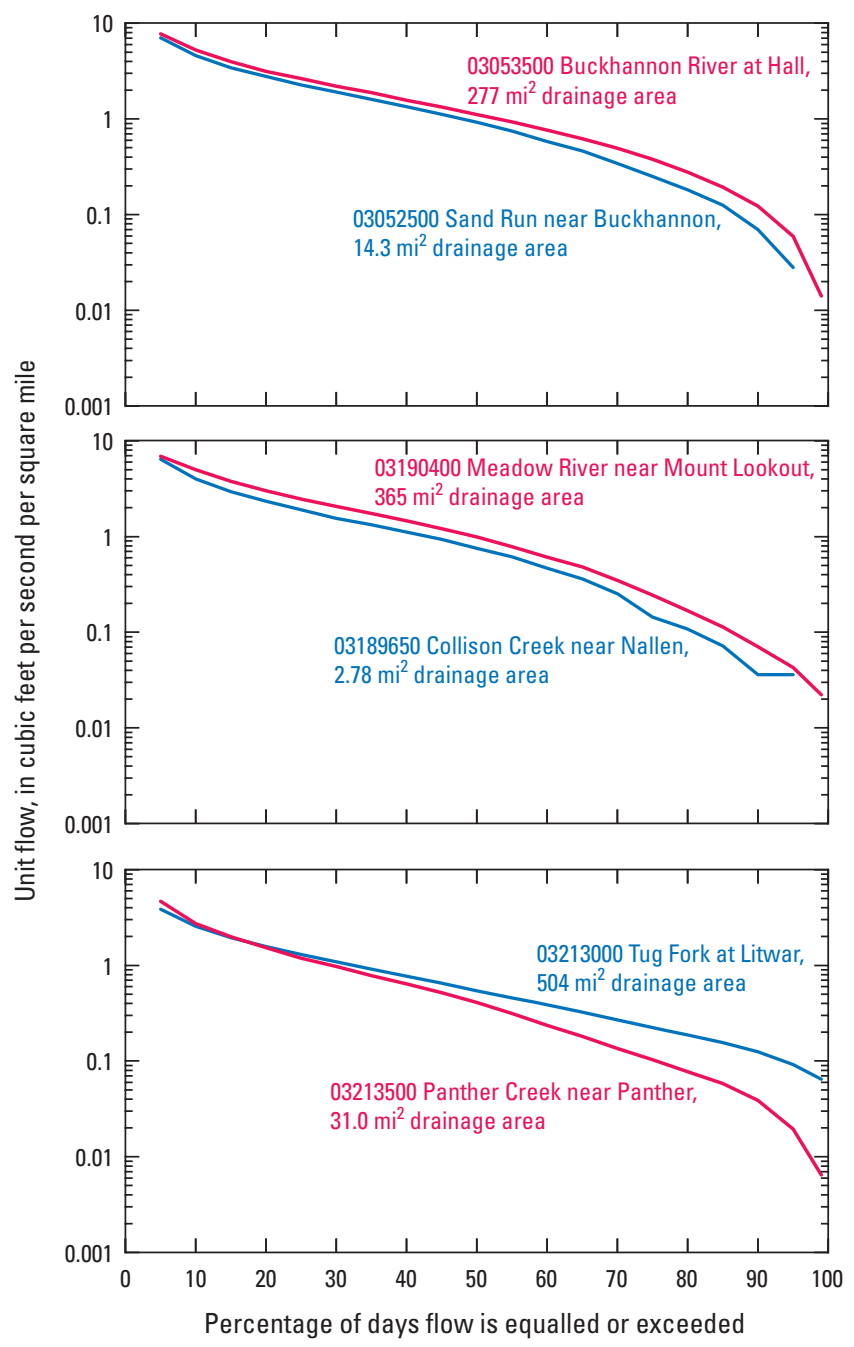

Figure 7. Flow duration of selected pairs of small and large streams with streamgages that are near each other. (Data from Wiley, 2006; $\mathrm{mi}^{2}$, square miles) 
Table 3. Annual water yield, drainage area, and mean annual precipitation for selected pairs of nested streamgages, 2006-2010.

[mi² ${ }^{2}$ square miles; NA, Not available. Precipitation data from PRISM Climate Group, 2012]

\begin{tabular}{|c|c|c|c|c|c|c|c|c|c|}
\hline \multirow{2}{*}{$\begin{array}{l}\text { Station } \\
\text { number }\end{array}$} & \multirow{2}{*}{ Streamgage name } & \multirow{2}{*}{$\begin{array}{c}\text { Drainage } \\
\text { area } \\
\left(\mathbf{m i}^{2}\right)\end{array}$} & \multirow{2}{*}{$\begin{array}{c}\text { Mean } \\
\text { annual } \\
\text { precipitation, } \\
\text { in inches }\end{array}$} & \multicolumn{6}{|c|}{$\begin{array}{l}\text { Annual water yield, in cubic feet per second } \\
\text { per square mile }\end{array}$} \\
\hline & & & & 2006 & 2007 & 2008 & 2009 & 2010 & Average \\
\hline 03052500 & Sand Run near Buckhannon, WV & 14.3 & 51.0 & 2.01 & 1.55 & 2.23 & 1.99 & 1.78 & 1.91 \\
\hline 03053500 & Buckhannon River at Hall, WV & 277 & 54.9 & 2.16 & 1.88 & 2.44 & 2.19 & 1.91 & 2.12 \\
\hline 03067510 & Shavers Fork near Cheat Bridge, WV & 60.2 & 58.8 & 2.61 & 2.97 & 2.95 & 2.54 & 2.92 & 2.80 \\
\hline 03069500 & Cheat River near Parsons, WV & 722 & 54.5 & 2.28 & 2.53 & 2.98 & 2.31 & 2.11 & 2.44 \\
\hline 03213500 & Panther Creek near Panther, WV & 31 & 43.8 & 0.59 & 1.00 & 0.65 & 1.55 & 1.74 & 1.10 \\
\hline 03214500 & Tug Fork at Kermit, WV & 1,280 & 44.7 & 0.71 & 1.00 & 0.68 & 1.38 & 1.26 & 1.01 \\
\hline 03198350 & Clear Fork at Whitesville, WV & 62.8 & 48.3 & NA & 1.18 & 1.01 & 1.25 & 1.62 & 1.26 \\
\hline 03198500 & Big Coal River at Ashford, WV & 391 & 47.3 & 0.89 & 1.19 & 1.05 & 1.43 & 1.60 & 1.23 \\
\hline 01610400 & Waites Run near Wardensville, WV & 12.6 & 43.8 & 0.87 & 1.20 & 0.87 & 0.75 & 1.25 & 0.99 \\
\hline 01611500 & Cacapon River near Great Cacapon, WV & 675 & 39.3 & 0.56 & 0.81 & 0.76 & 0.72 & 0.95 & 0.76 \\
\hline 03177710 & Bluestone River at Falls Mills, VA & 44.3 & 43.3 & 1.15 & 1.10 & 0.98 & 1.21 & 1.85 & 1.26 \\
\hline 03179000 & Bluestone River near Pipestem, WV & 395 & 40.6 & 0.89 & 1.02 & 0.85 & 1.20 & 1.59 & 1.11 \\
\hline
\end{tabular}

yield from Cheat River near Parsons (streamgage 03069500, drainage area $722 \mathrm{mi}^{2}$, table 3). At the two Bluestone River streamgages, Falls Mills (streamgage 03177710, drainage area $44.3 \mathrm{mi}^{2}$ ) and Pipestem (streamgage $03179000,395 \mathrm{mi}^{2}$ ), the headwater stream showed substantially greater water yield. In both of these examples, mean annual precipitation was greater in the headwater basin than in the main stem basin. For the pair of basins at which water yield was greater in the larger basin, mean annual precipitation in the larger basin was nearly 4 inches per year greater than in the smaller basin.

Mean annual precipitation was determined for the 86 map zones in the WWGT (fig. 8). Five map zones are referenced to index streamgages in basins that receive at least 10 percent more mean annual precipitation than the map zone, and three map zones are referenced to index streamgages in basins that receive at least 10 percent less mean annual precipitation than the map zone. These zones include areas with extensive Marcellus Shale development. One streamgage used in the WWGT as an index for drier areas with extensive Marcellus Shale development is Little Kanawha River near Wildcat (streamgage 03151400, map zone 31); this basin receives a mean precipitation of 53 inches per year (in/yr) (table 4). Map zones representing drier parts of the Little Kanawha River Basin (map zone 31, 48 in/yr) and the West Fork Basin (map zone 50, $48 \mathrm{in} / \mathrm{yr}$ ) are referenced to the Wildcat streamgage, resulting in an overestimation of available water. Map zones 27 and 48, referenced to Sand Run near Buckhannon, WV (streamgage 03052500), and Wheeling Creek below Blaine,
OH (streamgage 03111548), respectively, receive at least 10 percent more mean annual precipitation than the index basins; in these map zones, available water is likely to be underestimated.

Heterogeneous areas can also lead to problematic flow estimates. Estimating flows on an ungaged stream using a basin that receives precipitation more frequently than the ungaged basin could lead to inaccurate flow estimates. WWGT map zones were drawn along basin boundaries, and heterogeneity among index streamgage basins was generally comparable to that among map zones. As a result of this, 36 of 86 map zones include areas in which mean annual precipitation differs by $10 \mathrm{in} / \mathrm{yr}$ or more. Seven map zones (map zones 7 , $23,27,54,56,57$, and 67) include areas in which mean annual precipitation differs by $20 \mathrm{in} / \mathrm{yr}$ or more (table 4 ). Because mean annual precipitation generally increases with elevation, the greatest differences in precipitation among nearby areas tend to be in mountainous areas. Among the map zones with large differences in mean annual precipitation are some in areas with Marcellus Shale development (map zones 27, 30, $36,42,43$, and 50). The most uncertainty in flow estimates exists in areas where the precipitation distribution is uneven across the designated map zones. Incorrect estimates of flow are likely when flows have risen at an index streamgage draining a relatively large basin from an event in the headwaters of that basin, but estimates are being made for an ungaged stream near the streamgage that did not receive precipitation in the same event. 


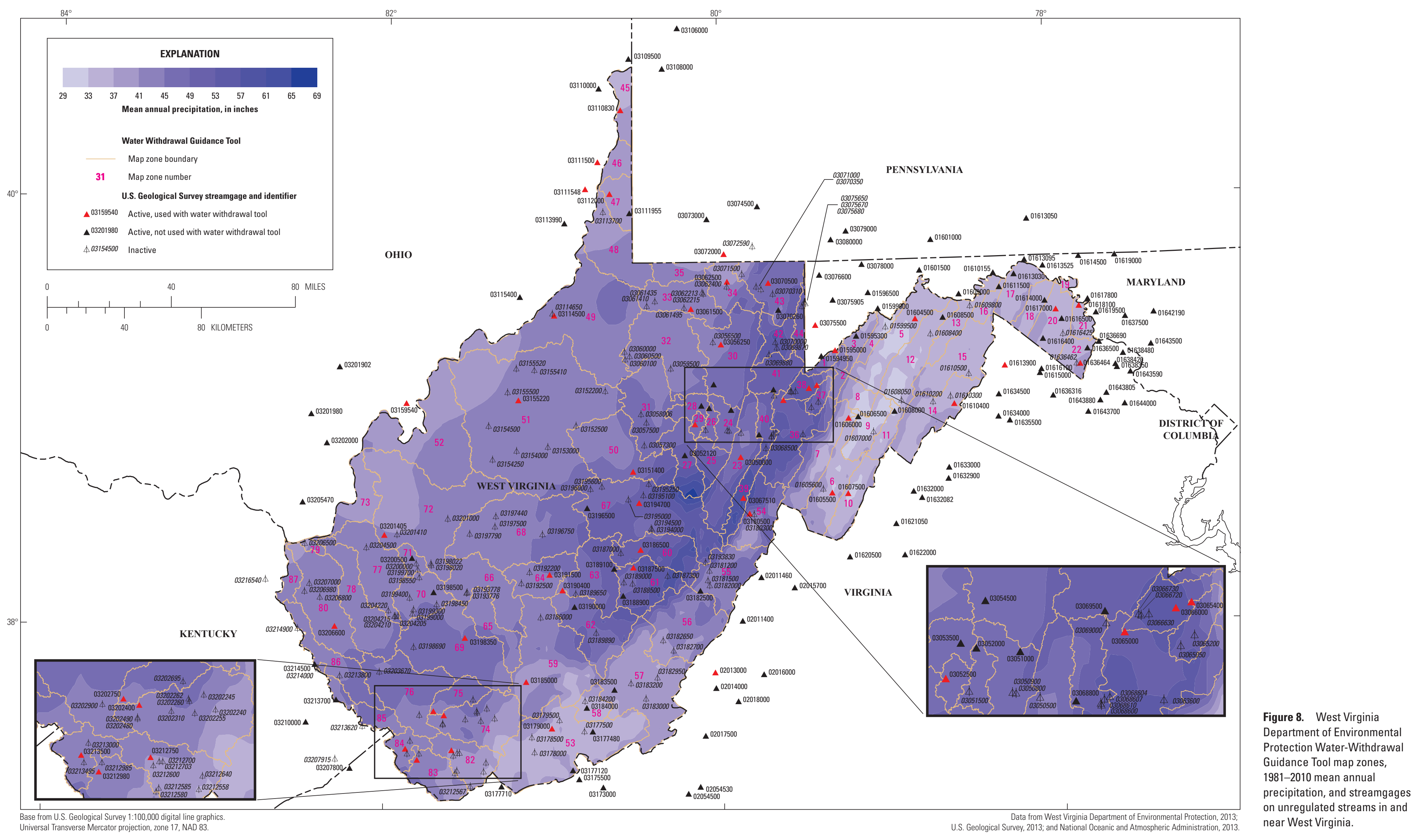


Table 4. Water-withdrawal tool map zones and associated index streamgages, and minimum, maximum, and mean annual precipitation, 1981-2010.

[Percentage difference mean precipitation; difference between index basin and map zone, as a percentage of the index basin. Data from PRISM Climate Group,

\section{Annual precipitation
for indicated map zone \\ in inches
indicated map zone,}

Min Max Range Mean

$\begin{array}{ll}\text { Annual precipitation } & \text { Percentage } \\ \text { difference }\end{array}$ basin, in inches
mean Min Max Range Mean precipitation \begin{tabular}{lllllllllll}
1 & 45 & 56 & 12 & 51 & North Branch Potomac River at Steyer, MD & 46 & 56 & 10 & 51 & -1 \\
\hline
\end{tabular} $\begin{array}{rrrrrrrrrrr}2 & 43 & 56 & 12 & 48 & \text { North Branch Potomac River at Steyer, MD } & 46 & 56 & 10 & 51 & 6 \\ 3 & 37 & 46 & 9 & 43 & \text { North Branch Potomac River at Steyer, MD } & 46 & 56 & 10 & 51 & 14\end{array}$ \begin{tabular}{lllllllllll}
5 & 36 & 46 & 10 & 37 & Patterson Creek near Headsville, WV & 36 & 46 & 10 & 37 & -6 \\
\hline
\end{tabular} $\begin{array}{lllllll}6 & 31 & 47 & 17 & 39 & \text { South Branch Potomac River at Franklin, WV }\end{array}$ $\begin{array}{lllll}35 & 47 & 12 & 42 & 7 \\ 35 & 63 & 28 & 43 & 1\end{array}$ $\begin{array}{llllll}7 & 35 & 63 & 28 & 42 & \text { North Fork South Branch Potomac River at Cabins, WV }\end{array}$ $\begin{array}{lllllll}8 & 33 & 48 & 14 & 38 & \text { North Fork South Branch Potomac River at Cabins, }\end{array}$ $\begin{array}{lllll}35 & 47 & 12 & 42 & 14\end{array}$ $\begin{array}{rrrrrrrrrrr}11 & 33 & 49 & 16 & 39 & \text { South Fork South Branch Potomac River at Brandywine, WV } & 34 & 49 & 15 & 40 & 4 \\ 11 & 33 & 46 & 13 & 39 & \text { South Fork South Branch Potomac River at Brandywine, WV } & 34 & 49 & 15 & 40 & 3\end{array}$ $\begin{array}{rrrrrlrrrrr}12 & 33 & 49 & 16 & 37 & \text { Patterson Creek near Headsville, WV } & 36 & 46 & 10 & 37 & 1 \\ 13 & 37 & 42 & 5 & 38 & \text { Patterson Creek near Headsville, WV } & 36 & 46 & 10 & 37 & -2\end{array}$ $\begin{array}{rrrrrlrrrrr}14 & 35 & 49 & 14 & 40 & \text { Waites Run near Wardensville, WV } & 39 & 47 & 8 & 44 & 8\end{array}$ $\begin{array}{rrrrrllllll}14 & 35 & 49 & 14 & 40 & \text { Waites Run near Wardensville, WV } & 39 & 47 & 8 & 44 & 8 \\ 15 & 36 & 46 & 9 & 39 & \text { Hogue Creek near Hayfield, VA } & 38 & 41 & 2 & 39 & 1\end{array}$ $\begin{array}{llllll}16 & 35 & 41 & 6 & 37 & \text { Hogue Creek near Hayfield, VA } \\ 17 & 37 & 41 & 4 & 39 & \text { Hogue Creek near Hayfeld, VA }\end{array}$ $\begin{array}{llllll}17 & 37 & 41 & 4 & 39 & \text { Hogue Creek near Hayfield, VA } \\ 18 & 39 & 41 & 3 & 39 & \text { Hogl C }\end{array}$ $\begin{array}{llllll}18 & 39 & 41 & 3 & 39 & \text { Hogue Creek near Hayfield, } \mathrm{VA} \\ 19 & 39 & 41 & 2 & 40 & \text { Tuscarora Creek above Martinsburg, WV }\end{array}$ $\begin{array}{llllll}20 & 38 & 40 & 1 & 39 & \text { Tuscarora Creek above Martinsburg, WV }\end{array}$ $\begin{array}{llllll}21 & 39 & 40 & 1 & 39 & \text { Rockymarsh Run at Scrabble, WV }\end{array}$ $\begin{array}{rrrrrr}22 & 39 & 41 & 2 & 39 & \text { Bullskin Run below Kabletown, WV }\end{array}$ $\begin{array}{llllll}23 & 45 & 67 & 23 & 51 & \text { Tygart Valley River near Dailey, WV }\end{array}$ $\begin{array}{rrrrrl}24 & 48 & 53 & 5 & 50 & \text { Sand Run near Buckhannon, WV } \\ 25 & 52 & 66 & 14 & 55 & \text { Sall Rar }\end{array}$ $\begin{array}{llllll}25 & 52 & 66 & 14 & 55 & \text { Sand Run near Buckhannon, WV }\end{array}$ $\begin{array}{rrrrrrr}26 & 50 & 52 & 2 & 51 & \text { Sand Run near Buckhannon, WV }\end{array}$ $\begin{array}{llllll}27 & 48 & 70 & 22 & 57 & \text { Sand Run near Buckhannon, WV }\end{array}$ $\begin{array}{lllllll}28 & 48 & 51 & 3 & 49 & \text { Sand Run near Buckhannon, WV } \\ 29 & 49 & 52 & 3 & 5 & \text { S }\end{array}$ $\begin{array}{llllll}29 & 49 & 52 & 3 & 51 & \text { Sand Run near Buckhannon, WV }\end{array}$ $\begin{array}{llllll}30 & 45 & 56 & 11 & 49 & \text { Three Fork Creek near Grafton, WV }\end{array}$

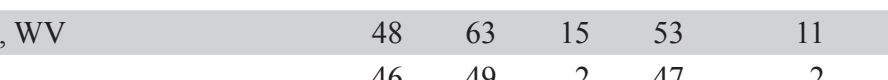
$\begin{array}{lllllllllll}33 & 44 & 49 & 5 & 47 & \text { Buffalo Creek at Barrackville, WV } & 46 & 49 & 2 & 47 & 2 \\ 3 & 42 & 5 & & 45 & \text { Deflo } & 2 & 47 & 1\end{array}$ $\begin{array}{rrrrrlrrrrr}33 & 44 & 49 & 5 & 47 & \text { Buffalo Creek at Barrackville, WV } & 46 & 49 & 2 & 47 & 1 \\ 34 & 42 & 51 & 9 & 45 & \text { Deckers Creek at Morgantown, WV } & 42 & 51 & 9 & 48 & 5 \\ 35 & 43 & 47 & 4 & 45 & \text { Dunkard Creek at Shannopin, PA } & 42 & 47 & 5 & 44 & -2\end{array}$ $\begin{array}{llllll}35 & 43 & 47\end{array}$ \begin{tabular}{|rrrrrll}
36 & 45 & 63 & 18 & 54 & Dry Fork at Hendricks, WV \\
\hline 37 & 52 & 59 & 7 & 54 & Blackwater River near Davis, WV
\end{tabular} $\begin{array}{llllll}38 & 50 & 58 & 8 & 56 & \text { Blackwater River at Davis, WV }\end{array}$ $\begin{array}{lllllll}39 & 53 & 63 & 9 & 58 & \text { Shavers Fork near Cheat Bridge, WV }\end{array}$ $\begin{array}{lllllll}40 & 50 & 57 & 8 & 52 & \text { Shavers Fork near Cheat Bridge, WV }\end{array}$ $\begin{array}{lllllll}41 & 50 & 57 & 7 & 52 & \text { Three Fork Creek near Grafton, WV }\end{array}$ \begin{tabular}{|llllll}
42 & 45 & 57 & 12 & 53 & Three Fork Creek near Grafton, WV \\
\hline 43 & 42 & 54 & 12 & 48 & Big Sandy Creek at Rockville, WV
\end{tabular} $\begin{array}{lllll}38 & 41 & 2 & 39 & 4 \\ 38 & 41 & 2 & 39 & 1\end{array}$ $\begin{array}{lllll}38 & 41 & 2 & 39 & -0\end{array}$ $\begin{array}{lllll}39 & 39 & 1 & 39 & -1\end{array}$ $\begin{array}{lllll}39 & 39 & 0 & 39 & -0\end{array}$ $\begin{array}{rrrrr}39 & 40 & 1 & 39 & -1 \\ 45 & 67 & 23 & 52 & 2\end{array}$ $\begin{array}{lllll}50 & 52 & 3 & 51 & 1\end{array}$ $\begin{array}{lllll}50 & 52 & 3 & 51 & -9\end{array}$ $\begin{array}{rrrrr}50 & 52 & 3 & 51 & -12\end{array}$ $\begin{array}{lllll}50 & 52 & 3 & 51 & 1\end{array}$ $\begin{array}{lllll}45 & 63 & 5 & 44 & -2\end{array}$ \begin{tabular}{rrrrr}
52 & 59 & 7 & 54 & 0 \\
\hline 5 & 59 & 9 & 55 & -2
\end{tabular} $\begin{array}{rrrrr}53 & 63 & 9 & 59 & -2\end{array}$ $\begin{array}{rrrrr}53 & 63 & 9 & 59 & 11\end{array}$ $\begin{array}{lllll}48 & 53 & 5 & 49 & -6 \\ 48 & 53 & 5 & 49 & -9\end{array}$

Table 4. Water-withdrawal tool map zones and associated index streamgages, and minimum, maximum, and mean annual precipitation, 1981-2010.-Continued

[Percentage difference mean precipitation; difference between index basin and map zone, as a percentage of the index basin. Data from PRISM Climate Group,

\section{Annual precipitation}

indicated map zo
in inches

Min Max Range Mean

\section{$49 \quad 54 \quad 5 \quad 52$ Yo}

Youghiogheny River near Oakland, MD

$\begin{array}{llllll}4 & 38 & 40 & 2 & 39 & \text { Short Creek near Dillonvale, OH } \\ 47 & 39 & 43 & 4 & 41 & \text { Wheeling Creek at Elm Grove, WV }\end{array}$

$\begin{array}{lllllll}48 & 40 & 48 & 9 & 45 & \text { Whelling Crek below Blaine, } \mathrm{OH}\end{array}$

$\begin{array}{rrrrrr}48 & 40 & 48 & 9 & 45 & \text { Wheeling Creek below Blaine, OH } \\ 49 & 42 & 50 & 8 & 46 & \text { Middle Island Creek at Little, WV }\end{array}$

$\begin{array}{lllllll}50 & 45 & 62 & 17 & 48 & \text { Little Kanawha River near Wildcat, WV }\end{array}$

$\begin{array}{lllllll}51 & 42 & 49 & 7 & 46 & \text { South Fork Hughes River below Macfarlan, WV }\end{array}$

$\begin{array}{llllll}52 & 40 & 45 & 5 & 43 & \text { Shade River near Chester, } \mathrm{OH}\end{array}$

$\begin{array}{lll}14 & 39 & \text { Bluestone River near Pipestem, W }\end{array}$

$\begin{array}{rrrrrrl}54 & 40 & 62 & 22 & 49 & \text { Greenbrier River at Durbin, WV } \\ 55 & 41 & 60 & 19 & 47 & \text { Greenbrier River at Durbin, WV }\end{array}$

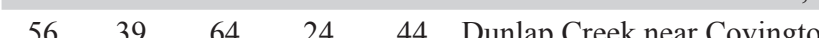

\begin{tabular}{llllll}
57 & 37 & 59 & 22 & 41 & Dunlap Creek near Covington, VA \\
\hline
\end{tabular}

$\begin{array}{rrrrrr}58 & 37 & 45 & 8 & 39 & \text { Piney Creek at Raleigh, WV }\end{array}$

$\begin{array}{llllllll}59 & 39 & 53 & 15 & 45 & \text { Piney Creek at Raleigh, WV }\end{array}$

$\begin{array}{llllll}60 & 51 & 65 & 13 & 58 & \text { Williams River at Dyer, WV } \\ 61 & 49 & 65 & 16 & 57 & \text { Cranberry River near Richwood, WV }\end{array}$

$\begin{array}{lllllll}62 & 43 & 61 & 18 & 50 & \text { Meadow River near Mount Lookout, WV }\end{array}$

$\begin{array}{lllllll}62 & 43 & 61 & 18 & 50 & \text { Meadow River near Mount Lookor, } \\ 63 & 46 & 60 & 14 & 51 & \text { Peters Creek at Lockwood, WV }\end{array}$

$\begin{array}{lllrrr}64 & 44 & 50 & 5 & 46 & \text { Peters Creek at Lockwood, WV }\end{array}$

$\begin{array}{llllll}65 & 42 & 50 & 7 & 46 & \text { Clear Fork at Whitesville, WV }\end{array}$

$\begin{array}{llllll}66 & 43 & 48 & 5 & 45 & \text { Peters Creek at Lockwood, WV } \\ 67 & 48 & 71 & 23 & 55 & \text {. }\end{array}$

$\begin{array}{llllll}67 & 48 & 71 & 23 & 55 & \text { Elk River below Webster Springs, WV }\end{array}$

$\begin{array}{rrrrrl}68 & 43 & 53 & 9 & 47 & \text { Peters Creek at Lockwood, WV } \\ 69 & 42 & 55 & 14 & 47 & \text { Clear Fork at Whitesville, WV }\end{array}$

$\begin{array}{lllllll}70 & 45 & 48 & 3 & 47 & \text { Hurricane Creek at Hurricane, WV }\end{array}$

$\begin{array}{llllll}71 & 43 & 46 & 3 & 45 & \text { Hurricane Creek at Hurricane, WV }\end{array}$

$\begin{array}{llllll}72 & 40 & 46 & 6 & 43 & \text { Hurricane Creek at Hurricane, WV } \\ 73 & 41 & 42 & 2 & 42 & \text {. }\end{array}$

$\begin{array}{llllll}73 & 41 & 42 & 2 & 42 & \text { Hurricane Creek at Hurricane, WV }\end{array}$

$\begin{array}{lllllll}74 & 41 & 52 & 10 & 47 & \text { Guyandotte River near Baileysville, WV }\end{array}$

$\begin{array}{llllll}75 & 46 & 56 & 10 & 49 & \text { Clear Fork at Clear Fork, WV }\end{array}$

$\begin{array}{llllll}76 & 44 & 52 & 7 & 47 & \text { Clear Fork at Clear Fork, WV } \\ 77 & 42 & 48 & 6 & 44 & \text { Hurricane Creek at Hurricane, WV }\end{array}$

$\begin{array}{llllll}78 & 42 & 48 & 5 & 45 & \text { East Fork Twelvepole Creek near Dunlow, W }\end{array}$

$\begin{array}{llllll}79 & 42 & 43 & 1 & 42 & \text { Hurricane Creek at Hurricane, WV }\end{array}$

$\begin{array}{llllll}80 & 42 & 47 & 5 & 45 & \text { East Fork Twelvepole Creek near Dunlow, WV }\end{array}$

$\begin{array}{lllllll}82 & 41 & 48 & 6 & 44 & \text { Tug Fork at Welch, WV }\end{array}$

\begin{tabular}{llllll}
83 & 42 & 45 & 3 & 44 & Dry Fork at Beartown, WV \\
\hline 84 & 43 & 46 & 2 & 44 & Panther Creek near Panther, WV
\end{tabular}

$\begin{array}{llllll}85 & 43 & 47 & 4 & 46 & \text { Panther Creek near Panther WV }\end{array}$

$\begin{array}{llllll}86 & 44 & 47 & 4 & 45 & \text { East Fork Twelvepole Creek near Dunlow, WV }\end{array}$

$\begin{array}{llllll}87 & 43 & 44 & 1 & 43 & \text { East Fork Twelvepole Creek near Dunlow, WV }\end{array}$
Annual precipitation Percentage A the index streamgage difference,
basin, in inches Max Range Mean precipitation 54 $\begin{array}{lllll}39 & 41 & 1 & 40 & 1\end{array}$ $\begin{array}{lllll}39 & 45 & 5 & 41 & 2\end{array}$ \begin{tabular}{rrrrr}
40 & 41 & 1 & 41 & -10 \\
\hline & 49 & 5 & 46 & 0
\end{tabular} $\begin{array}{lllll}44 & 49 & 5 & 46 & 0\end{array}$ $\begin{array}{lllll}45 & 47 & 1 & 46 & 1\end{array}$ $\begin{array}{rrrrr}37 & 53 & 15 & 41 & -4 \\ 43\end{array}$ $\begin{array}{lllll}43 & 57 & 14 & 50 & 2\end{array}$ $\begin{array}{lllll}43 & 57 & 14 & 50 & 7\end{array}$ $\begin{array}{rrrrr}37 & 48 & 10 & 41 & -8 \\ 37 & 48 & 10 & 41 & 0\end{array}$ $40-47$ $\begin{array}{ccccc}40 & 47 & 7 & 43 & 9 \\ 40 & 47 & 7 & 43 & -4\end{array}$ $\begin{array}{lllll}1 & 65 & 13 & 60 & 2\end{array}$ $\begin{array}{lllll}4 & 65 & 16 & 60 & 5 \\ 43 & 61 & 18 & 50 & -0\end{array}$ $\begin{array}{rrrrr}43 & 61 & 18 & 50 & -0 \\ 46 & 49 & 3 & 47 & -8\end{array}$ $\begin{array}{lllll}46 & 49 & 3 & 47 & 2 \\ 46 & 52 & 6 & 48 & 5\end{array}$ $\begin{array}{lllll}46 & 52 & 6 & 48 & 5 \\ 49 & 79 & 3 & 47 & 4\end{array}$ $\begin{array}{lllll}49 & 71 & 21 & 58 & 6\end{array}$ $\begin{array}{lllll}46 & 49 & 3 & 47 & 1 \\ 46 & 52 & 6 & 48 & 2\end{array}$ $\begin{array}{lllll}4 & 43 & 2 & 42 & -10 \\ 4 & 43 & 2 & 42 & -5\end{array}$ $\begin{array}{lllll}41 & 43 & 2 & 42 & -5\end{array}$ $\begin{array}{rrrrr}41 & 43 & 2 & 42 & -2 \\ 4 & 52 & 10 & 47 & 2\end{array}$ $\begin{array}{lllll}41 & 52 & 10 & 47 & 0\end{array}$ $\begin{array}{lllll}46 & 56 & 10 & 49 & 0\end{array}$ $\begin{array}{lllll}41 & 43 & 2 & 42 & -5\end{array}$ $\begin{array}{lllll}41 & 43 & 2 & 42 & -0\end{array}$ $\begin{array}{lllll}41 & 48 & 6 & 44 & -0\end{array}$ $\begin{array}{lllll}42 & 47 & 5 & 44 & 0\end{array}$ $\begin{array}{lllll}43 & 44 & 1 & 44 & -1\end{array}$ $\begin{array}{rrrrr}43 & 44 & 1 & 44 & -4 \\ 46 & 47 & 1 & 47 & 2\end{array}$ $\begin{array}{lllll}46 & 47 & 1 & 47 & 7\end{array}$ 


\section{Effects of Basin and Channel Characteristics on Flow Timing}

Estimating flow by use of index streamgages is also complicated by the effects of the channel size and the basin shape on the timing of flows. Smaller basins rise and fall more quickly in response to precipitation than do large basins. Basin shape also affects timing of rises and recessions, in that distances along a stream within a compact basin are shorter than distances within a long, narrow basin. Within a compact basin, large and small streams are likely to rise and recede at the same times (fig. 9). As an example, rises and recessions, shown by hourly (or more frequent) observations, on the Blackwater River at Davis (streamgage 03066000) and Dry Fork at Hendricks (streamgage 03065000 , fig. $9 B$ ) are nearly simultaneous, despite the difference in basin areas $\left(85.9 \mathrm{mi}^{2}\right.$ for Blackwater River and $349 \mathrm{mi}^{2}$ for Dry Fork). These streams, tributaries to the Black Fork of the Cheat River, are in a mountainous part of the Appalachian Plateaus. The drainage pattern is dendritic, the basins are compact, and the distance between the basin centroids is small. The centroids of the basins are 17.4 miles apart, and the streamgages themselves are 9.12 miles apart.

In contrast, Waites Run at Wardensville, a tributary of the Cacapon River, typically recedes many hours before the Cacapon River rises at the streamgage near Great Cacapon. The centroids of these two basins are 10.6 miles apart, but the gages are 40.3 miles apart. The Cacapon River is in the Valley and Ridge Physiographic Province, drainage is trellised, and the basin is long and narrow. Distribution of precipitation during a storm is among the factors affecting flow timing. During rain events, precipitation distribution within basins is likely to cause the greatest variation in flow timing in large basins. Differences in the timing of runoff from the same storms, among and within basins, are among the aspects of streamflow that are reflected in correlation of daily flows.

\section{Relation of Flow Duration, Timing, and Correlation to Hypothetical Seasonal and Annual Withdrawal Criteria}

Annual, seasonal, and monthly flow statistics have been proposed as criteria for thresholds for withdrawing water from streams (Poff and others, 2010; Richter and others, 2011; New York Department of Environmental Conservation, 2011). Assessing the effects of flow magnitude and alteration on aquatic life is outside the scope of this report. However, the coverage and resolution of the streamgaging network may influence the practicality of selecting among an annual, seasonal, or monthly flow statistic for withdrawal criteria. As an example, annual and seasonal 75-percent flow-duration values (D75) are compared; annual and seasonal statistics representative of 1930 to 2002, as determined by Wiley (2006), were used for these comparisons.
The D75 is the daily flow, in cubic feet per second, which is equaled or exceeded on 75 percent of the days. Over the long term, the same average number of days per year, 91, have flows that are less than either the annual or seasonal D75. The distribution of those days is different; few years have exactly 91 days with flows less than either the annual or monthly D75 (fig. 10). Commonly in West Virginia, flow is greater than the annual D75 for several months in winter and spring, even during dry years, but falls below the annual D75 for most of the late summer and fall, even during wet years. At Sand Run near Buckhannon during water years 2006-10, flow was less than the annual D75 for several months every year, but flow on many days during those months exceeded the seasonal D75. During 2007, 2009, and 2010, spring flows exceeded the annual D75 but were less than the seasonal D75.

In addition to when water may be withdrawn under different scenarios, the length of time between withdrawal opportunities is of potential interest to water users. The maximum numbers of days between exceedances of the 75-percent flow durations are listed in tables 5-8 (at end of report) for 15 streamgages in West Virginia with nearly continuous, unregulated record during the 1930-2011 water years. There is a difference in the number of days per year that annual and seasonal flow-duration values of the same nominal value are exceeded. In some years, the seasonal 75-percent flow durations are exceeded on more days, and in some years, the annual statistics are exceeded on more days.

During water years 1930-2011, the average number of days per water year that the 15 streamgages exceeded the annual D75 ranged from 178 in 1999 to 346 in 2003 (table 5). The average number of days per water year that flow at 15 streamgages exceeded the seasonal D75 ranged from 164 in 1966 to 353 in 1974 (table 6). The annual D75 value was exceeded on more days than the seasonal D75 value in 37 of 82 years. For the annual averages at the 15 streamgages, the number of days when flow exceeded annual and seasonal D75 values differed by 7 or fewer days during 30 of 82 years and 14 or fewer days during 57 of 82 years. The maximum difference was 42 days in 1930, when the annual D75 value was exceeded on an average of 238 days, but seasonal D75 values were exceeded on only 196 days.

For individual streamgages, the annual D75 was exceeded the fewest days (91) during any water year at Shenandoah River at Millville (01636500) in 2002; annual D75 was exceeded the second fewest days (127) at the same streamgage in 1966. Flow at three streamgages was greater than the annual D75 for entire water years: Shenandoah River at Millville in 1949 and 1973, and Big Coal River at Ashford (03198500) and Tug Fork near Kermit (03214000), both in 2004. The seasonal D75 was exceeded the fewest (51) and second fewest (89) days during any water year at Shenandoah River near Millville in 2002 and 1966, respectively; in 1966, seasonal D75 was exceeded on only 3 more days at Cacapon River near Great Cacapon (01611500) than at Shenandoah River near Millville. The seasonal D75 value was exceeded 

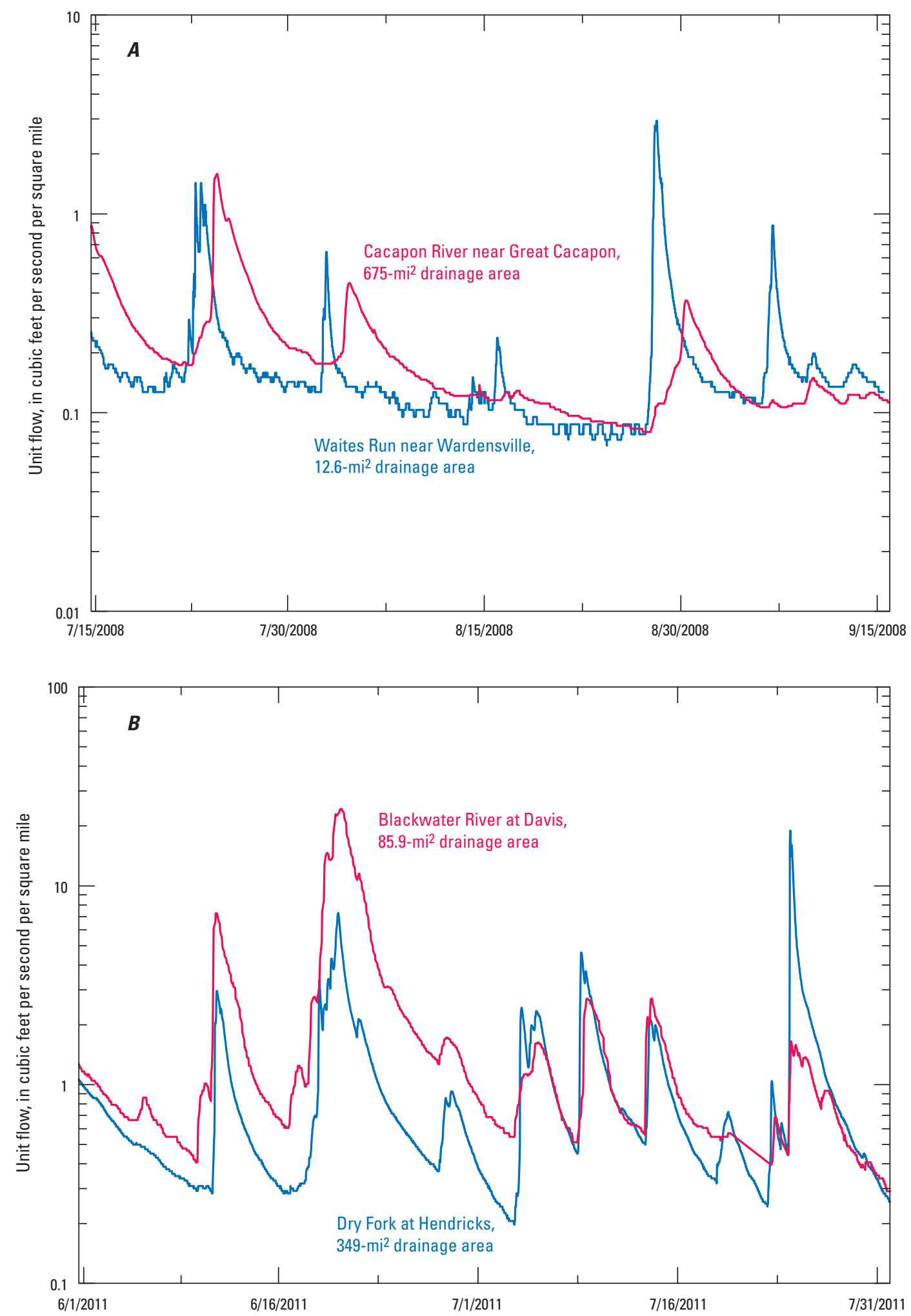

Figure 9. Timing of rises and recessions of flow at $A$, Waites Run near Wardensville and Cacapon River near Great Cacapon, 2008, and $B$, Blackwater River at Davis and Dry Fork at Hendricks, 2011, in West Virginia. (mi², square miles) 


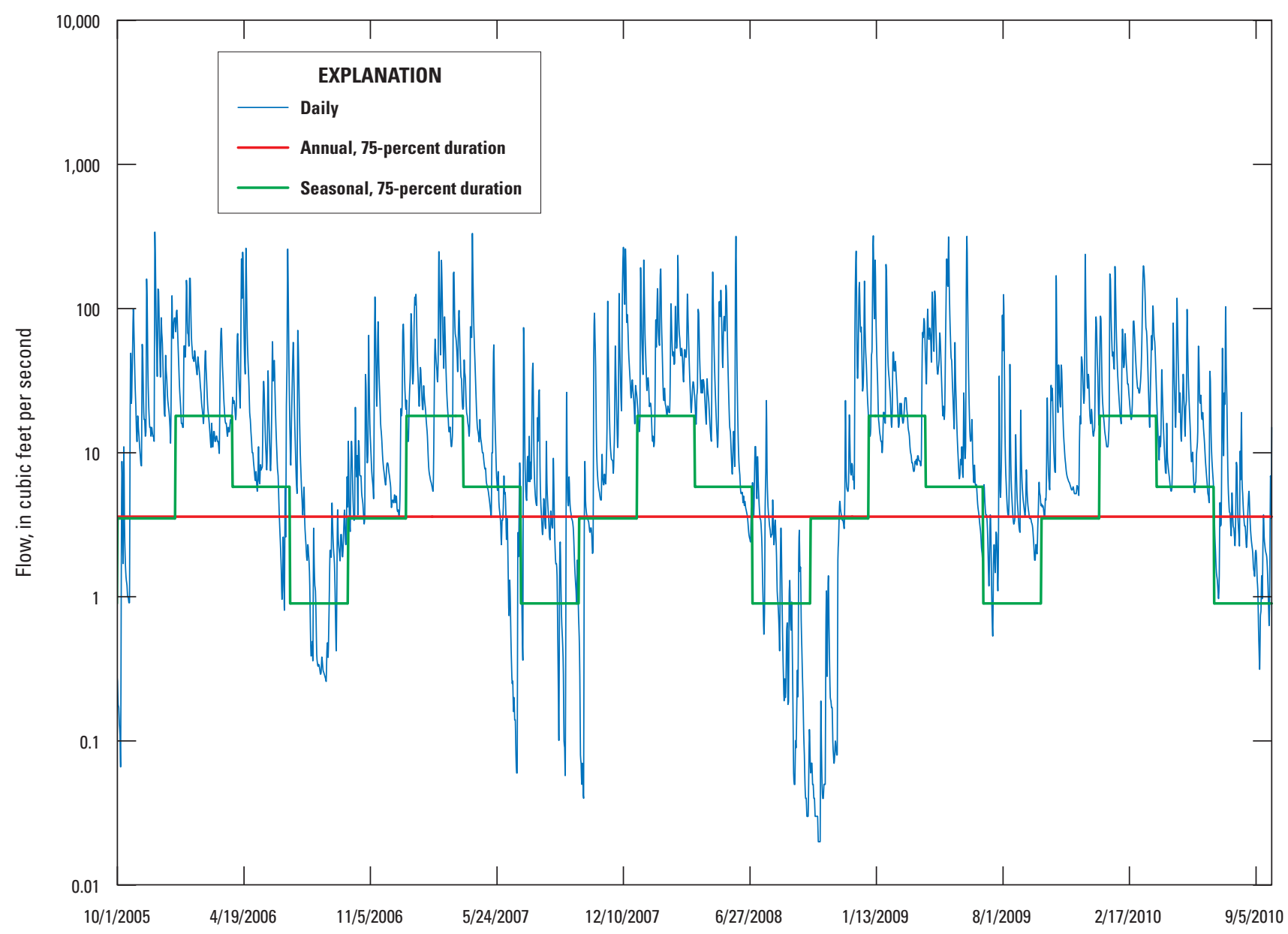

Figure 10. Daily flow and annual and seasonal 75-percent flow durations at Sand Run near Buckhannon, West Virginia, water years 2006-2010. 
for entire water years at four streamgages: Cacapon River near Great Cacapon (01611500 in 1964 and 2004), Shenandoah River near Millville (01636500 in 1973, 1996, and 1997), Williams River at Dyer (03186500 in 1950), and Tug Fork near Kermit (03214000 in 1974).

In contrast to the inconsistent numbers of days when the annual and seasonal D75 were exceeded, the interval between exceedance of annual D75 values was consistently greater than the interval between exceedance of seasonal D75 values. For individual streamgages, the maximum interval between exceedances of annual D75 values was 222 days at Big Coal River at Ashford (03198500) in 1931 (table 7). All 15 of the streamgages had an interval of at least 130 days between exceedances of annual D75 values during the 1930-2011 water years. At four streamgages (South Branch Potomac River near Springfield, 01608500; Shenandoah River at Millville, 01636500; Big Sandy Creek at Rockville, 03070500; and Big Coal River at Ashford, 03198500) the interval between exceedances of the annual D75 values was greater than 180 days at least once. The maximum interval between exceedances of seasonal D75 values was longer than 180 days at only one streamgage during only one year (Big Sandy Creek at Rockville, 03070500, in 1954; table 8). The minimum interval between exceedances of annual and seasonal D75 values, zero days, occurred at the streamgages where flow remained above the annual and seasonal D75 for entire years.

For averages of the 15 streamgages, the maximum number of days between exceedances of annual D75 values was greater than or equal to the maximum number of days between exceedances of seasonal D75 values in 79 of 82 years. The three exceptions are 1977, 1994, and 2003. Averages were equal in 1978 and 1980. Differences in the number of days between exceedances of annual and seasonal D75 values were 7 or fewer during 15 of 82 years and 14 or fewer during 42 of 82 years. The maximum difference was 32 days, in 1999.

Use of monthly or seasonal flow statistics may require greater accuracy and precision from the streamgaging network than the use of annual flow statistics. Because the magnitudes of many monthly or seasonal values for D75 are less than those for the annual D75, precision of the stage-discharge relations (the rating) for low flows at index streamgages is of great importance. Small changes in the stage-flow rating resulting from intermittent scour, and especially from annual leaf accumulation in the fall, are common and would be of consequence in assessing the data used to estimate flows at ungaged sites in real-time. The relatively weak correlations of daily flows in summer compared to fall, winter, and spring are relevant in determining how flows are to be estimated, particularly if frequent decisions are to be made concerning flows close to the threshold. Management options that would not require the use of index streamgages during times when they are unlikely to provide accurate estimates include the use of off-stream storage and direct measurement of flow at the time of proposed withdrawal.

\section{Correlation of Daily Flows at Streamgages}

Index streamgages typically have been selected by location or by best professional judgment. If index streamgages are to be used for withdrawal-management purposes, a systematic method is desirable.

\section{Analytical Approach and Site Selection}

A systematic method, the Map Correlation Method, for determining appropriate index streamgages to be used for estimating daily flows has been developed and applied in Massachusetts (Archfield and others, 2010; Archfield and Vogel, 2010), the Connecticut River Basin (Archfield and others, 2013), Iowa (Linhart and others, 2012), and Pennsylvania (Stuckey and others, 2012). The Map Correlation Method relies on spatial patterns in the correlation of daily flows among streamgages. Correlations of daily flows are computed among a group of streamgages, and spatial patterns in correlation are determined by ordinary kriging. A set of correlation maps is produced that depict the predicted correlation of daily flows for each streamgage that was included in the analysis. Index streamgages are selected using map correlation and flow-duration exceedance probability regression equations to estimate daily mean flow for an ungaged location. The streamgage for which daily flows are most likely to be correlated with those at any ungaged stream location of interest can be determined by referring to the maps. Previous applications of the Map Correlation Method have been used to estimate time series of daily flows for ungaged stream locations.

Stuckey and others (2012) tested several modifications to the Map Correlation method and reported two that generally improved results. The first modification was in the metric used to describe the location of the streamgage. Areas of predicted correlation with the index streamgages are determined by ordinary kriging of the correlation coefficients. Stuckey and others (2012) compared, for two basins, the use of the coordinates of the centroid of the gaged basin to the use of coordinates of the gage location at the basin outlet for kriging; centroid distance made little difference in one basin, but improved results in the other.

The second modification, which made less difference to the final results, was the selection of a correlation coefficient. Archfield and others (2010) determined correlation by using Pearson's $r$ for log-transformed daily flows. Stuckey and others (2012) compared the accuracy of synthesizing flows in two basins by using Spearman's rho, a rank-based correlation coefficient, to that achieved by using Pearson's $r$ on log-transformed daily flows. Spearman's rho is computed by ranking the observations from smallest to largest, and then performing the same computation as used for Pearson's $r$ on 
the pairs of ranks instead of the pairs of observations. Both correlation coefficients can range from -1 for a perfect negative correlation to 1 for a perfect positive correlation, and both equal zero for a perfectly uncorrelated dataset. In 10 tests, five scenarios tested in two basins, Nash-Sutcliffe efficiency values of flows synthesized using Spearman's rho were the same as those synthesized using Pearson's $r$ for five tests, were greater for three tests, and were less for two tests. Although the results achieved by Stuckey and others (2012) were generally similar using either correlation coefficient, Spearman's rho offers several logical advantages over Pearson's r. Spearman's rho, unlike Pearson's $r$, does not rely on the assumption that a relation between two sets of observations is linear. A major advantage of Spearman's rho relative to Pearson's r performed on log-transformed daily flow values is that days with zero flow may be analyzed using a rank transformation, but days with zero flow are excluded from analysis that uses a logarithmic transformation.

For this study, correlations were determined using Spearman's rho. Kriging was done from basin centroids. Several different groups of index streamgages with different periods of record were used (table 1). Details of site and period selection are included in the discussion of analyses. Kriging was done using the ArcGIS 10.1 Geostatistical Analyst (Esri, 2012). Using ordinary kriging, a spherical semivariogram model was optimized for a target index streamgage and its correlations with other streamgages for a target period (Buffalo Creek at Barrackville, WV, 03161500, for 1992-2011). To ensure consistency among sites, the kriging parameters of the nugget, lag size, and partial sill determined for this streamgage were applied to all subsequent correlation maps (table 9). Root mean square error for the semivariogram model was 5.1 percent, and average standard error was 6.8 percent. Sensitivity testing was done for the dataset used to develop the semivariogram model; the nugget was varied by 10 percent and recomputed three times for each of the 222 points in the model. Standard errors for predictions generated during the sensitivity testing ranged from 2.0 percent to 5.0 percent.

In general, previous studies have not examined changes in the correlation of daily flows over time. Because managing withdrawals during summer and fall was an important consideration in this study, a comparison was made of seasonal differences in flow correlations and the manner in which those differences might affect the expected spatial correlation patterns. Comparisons also were made of flow correlations at long-term sites during periods previously identified as representing climatic variation in West Virginia (Wiley, 2006).

\section{Site Selection}

Flow data from streamgages operated in or near West Virginia were retrieved from the USGS National Water Information System: Web Interface (NWIS-Web) for 1930-2011. Data and coordinates for streamgages with a year or more of approved data were retrieved. Data were retrieved for all streamgages operated in West Virginia, and the parts of
Table 9. ArcGIS method report giving kriging parameters used to develop correlation maps.

$[\%$, percent $]$

\begin{tabular}{ll}
\hline Method: & Kriging \\
Type: & Ordinary \\
Output type: & Prediction \\
Trend type: & None \\
Searching neighborhood: & Standard \\
Neighbors to include: & 5 \\
Include at least: & 2 \\
Sector type: & Four and 45 degree \\
Major semiaxis: & 2.491609 \\
Minor semiaxis: & 2.491609 \\
Angle: & 0 \\
Number of lags: & 12 \\
Lag size: & 0.235945 \\
Variogram type: & Semivariogram \\
Nugget: & 0.002273 \\
Measurement error \%: & 100 \\
Model type: & Spherical \\
Range: & 2.491609 \\
Anisotropy: & false \\
Partial sill: & 0.016786 \\
\hline
\end{tabular}

Kentucky, Ohio, and Pennsylvania within 50 miles of West Virginia. Data were retrieved for streamgages in Virginia and Maryland within 50 miles of West Virginia that have been active during the 20 years prior to this study (1992-2011).

Information on regulation status was compiled from state low-flow frequency reports (Ruhl and Martin, 1991; Straub, 2001; Stuckey, 2006; Wiley, 2006; Roland and Stuckey, 2008; Doheny and Banks, 2010; Martin and Arihood, 2010; Austin and others, 2011; Koltun and Kula, 2013). Additional information on regulation status was compiled from Annual WaterData Reports and NWIS-Web pages and to determine periods of unregulated record (U.S. Geological Survey, 2013a, 2013b). Regulated periods that could be identified were removed from the database, although data were retained for unregulated periods at these streamgages. Streamgages at sites in basins altered by coal mining, urbanization, or other land uses known to affect flow characteristics were included so that their correlations could be explored, as were sites with basins that drain karst areas or urban areas.

Basin polygons were needed in order to obtain basin centroids. Basin polygons were obtained from Krstolic (2006), Falcone and others (2010), and the U.S. Environmental Protection Agency and USGS National Hydrologic Dataset Plus, version 2 (McKay and others, 2013). Basins were digitized for the streamgages in West Virginia that are not included in those reports. The six non-West Virginia basins were digitized for 
this study using the USGS web application StreamStats (U.S. Geological Survey, 2013c). Basins that are smaller than $2 \mathrm{mi}^{2}$ were not digitized, and the coordinates of their streamgages were substituted for the centroid coordinates. Basins without a published drainage area were excluded from analysis; these basins drain karst areas where the contributing drainage area is believed to differ from the surface drainage area. Basin polygons were available for most unregulated streamgages in West Virginia (table 1; Paybins, 2008).

\section{Correlation Computation}

Spearman's rho was determined using R, version 2.15.1 (R Core Team, 2012; table 10, available for download at http://dx.doi.org/10.3133/sir20145061). There were 55,737 pairs of sites with 365 or more days of concurrent record during 1930-2011 (table 11, available for download at http://dx.doi.org/10.3133/sir20145061). Values of rho range from 0.9977 to -0.02849 , and the overall median is 0.7066 . Although the correlations of all but 3 of the 55,737 pairs of sites were significantly different from $0(\mathrm{p}<0.05)$, differences between correlations are of greater interest.

The significance of differences between correlation coefficients is closely linked to the number of observations (table 12). In general, the stronger the correlations are, the more likely that differences between them are to be statistically significant. For instance, with 365 observations, correlation coefficients of 0.90 and 0.85 are significantly different ( $p<0.01$ ), as are correlation coefficients of 0.85 and 0.80 $(\mathrm{p}=0.03)$, but correlation coefficients of 0.80 and 0.75 are not significantly different $(p=0.09)$. With greater numbers of observations, even small differences between weak correlations may be significantly different; with 3,652 observations (10 years of daily flows), the difference between correlation coefficients of 0.25 and 0.20 is significant $(\mathrm{p}=0.02)$.

Table 12. Statistical significance of selected pairs of correlation coefficients at selected numbers of observations.

[n, number of observations; $<$, less than $]$

\begin{tabular}{ccccccc}
\hline \multicolumn{2}{c}{$\begin{array}{c}\text { Correlation } \\
\text { coefficient }\end{array}$} & & \multicolumn{5}{c}{ P value } \\
\cline { 1 - 4 } \cline { 5 - 7 } $\mathbf{r 1}$ & $\mathbf{r 2}$ & & $\mathbf{n = 9 0}$ & $\mathbf{n = 1 8 0}$ & $\mathbf{n = 3 6 5}$ & $\boldsymbol{n = 7 3 0}$ \\
\hline 0.95 & 0.90 & & 0.02 & $<0.001$ & $<0.001$ & $<0.001$ \\
0.95 & 0.85 & & $<0.001$ & $<0.001$ & $<0.001$ & $<0.001$ \\
0.90 & 0.85 & & 0.15 & 0.04 & $<0.001$ & $<0.001$ \\
0.90 & 0.80 & & 0.01 & $<0.001$ & $<0.001$ & $<0.001$ \\
0.90 & 0.75 & & $<0.001$ & $<0.001$ & $<0.001$ & $<0.001$ \\
0.85 & 0.80 & & 0.30 & 0.14 & 0.03 & $<0.001$ \\
0.85 & 0.75 & & 0.06 & 0.01 & $<0.001$ & $<0.001$ \\
0.85 & 0.70 & & 0.01 & $<0.001$ & $<0.001$ & $<0.001$ \\
0.80 & 0.75 & & 0.41 & 0.24 & 0.09 & 0.02 \\
\hline
\end{tabular}

Uncertainty associated with correlations decreases with the strength of the correlation, and the spatial extent of areas depicted at a given level of correlation is strongly influenced by the uncertainty of that underlying correlation. Because the strong correlations are more precise than the weak correlations, smaller differences between strong correlations are more meaningful than they would be between weak correlations. Maps in this report show strong correlations with finer resolution than weak correlations.

Spatial coverage of flow correlation would be limited if analysis were limited to streamgages with complete or nearly complete records for the entire period of interest; one of the principal questions of the study is "Which new or discontinued streamgages might be useful for filling spatial gaps in the existing network?" As the discussion of statistical power in relation to the number of observations indicates, minimum thresholds exist for a period of record to be significant. Because land use, climate, and other factors likely to affect flow correlation have changed over time, flow data obtained for a short period may not represent long-term flow characteristics; however, land-use and climate changes may cause long-term flow characteristics to be unrepresentative of present conditions.

\section{Comparison of Flow at Two Selected Streamgages}

Daily flows at nearby streamgages are often strongly correlated, although the correlation between a given pair of streamgages is likely to vary over time (fig. 11). As an example, daily flows in the 2009 water year for Buffalo Creek at Barrackville, WV (streamgage 03061500), and Dunkard Creek at Shannopin, Pennsylvania, generally compare well.

The basins are adjacent and of similar sizes (table 1). The Dunkard Creek Basin received an average of $44.2 \mathrm{in} / \mathrm{yr}$ of precipitation during 1980-2010, whereas the Buffalo Creek Basin received $47.3 \mathrm{in} / \mathrm{yr}$ of precipitation (table 4 ). The basin centroids are 13.7 miles apart, and the streamgages are 20.6 miles apart. Both basins have been, and continue to be, extensively mined for coal.

Unit flow at Dunkard Creek was generally slightly greater than that at Buffalo Creek (fig. 11). By mid-November, after evapotranspiration had decreased, unit flows at the two streamgages began to match closely. Throughout the rest of the fall, winter, and early spring, nearly every rise or recession on one stream was accompanied by a similar rise or recession on the other, although sometimes the magnitudes were slightly different. Several times, one stream rose when the other did not, apparently, because one received precipitation when the other did not. This pattern is common in West Virginia. During fall, winter, and early spring, precipitation usually results from frontal events that are evenly distributed throughout large areas, but during late spring and summer, scattered thunderstorms or differences in thunderstorm intensities result in greatly different amounts of rain in nearby areas. 

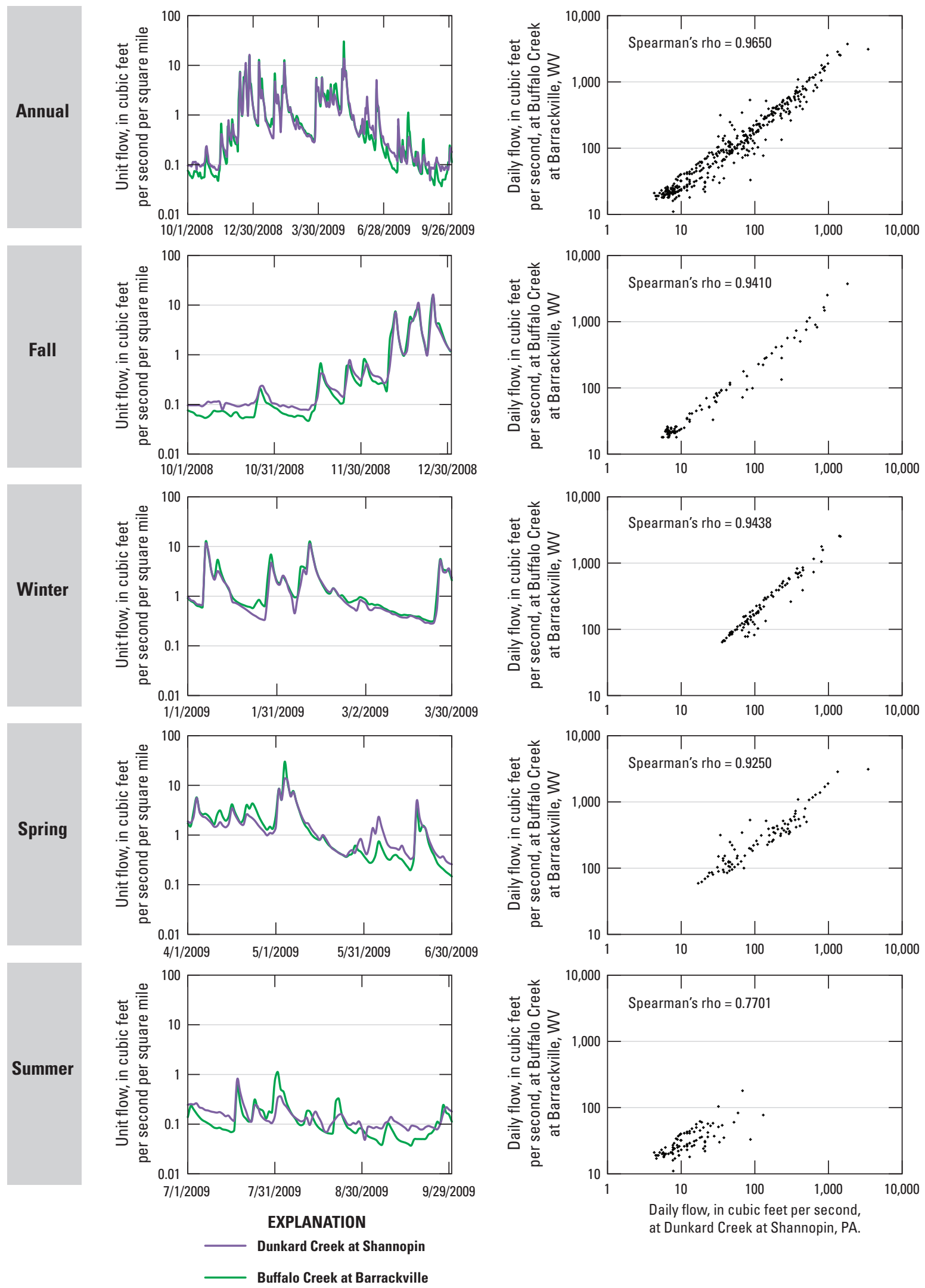

Figure 11. Annual and seasonal hydrographs, and scatterplots of daily flow at Dunkard Creek at Shannopin, Pennsylvania, in relation to Buffalo Creek at Barrackville, West Virginia, water year 2009. 
The strength of correlation of the daily flows could be measured by any of several statistics, but for comparison to a flow-duration value, which is based on the ranks of daily flows, a rank-based correlation coefficient such as Spearman's rho is appropriate. Spearman's rho values are shown in figure 11 with scatterplots of daily flow during water year 2009 for Buffalo Creek at Barrackville, WV, and Dunkard Creek at Shannopin, PA, for the entire year and for each of the four seasons.

At the beginning of water year 2009, flows were low at both streamgages. This condition began to change in late May, and during June 3-6, unit flow for Dunkard Creek was about three times that of Buffalo Creek. Throughout the rest of the spring and the summer, flows on the two streams were sometimes similar. Correlation between the two sites for the entire year $(0.9650)$ is slightly stronger than for any of the seasons because the seasonal differences in precipitation and base flow overshadow some of the smaller day-to-day fluctuations. Correlations between the two sites during fall (0.9410), winter (0.9438), and spring (0.9250) were generally strong and similar to each other, and correlation was weaker during the summer (0.7701). Inspection of the scatterplot for summer shows substantial differences in all flows with the greatest differences associated with the manner in which storms moved through the region.

\section{Relation of Correlation Coefficients to Flow Estimation}

To assess the relevance of different correlations, a comparison was made for the same 15 streamgages in West Virginia with nearly continuous unregulated records for 1930 to 2011 that were used to assess low-flow trends by Wiley (2006). The analysis was limited to streamgages from West Virginia because low-flow statistics were developed for West Virginia to be representative of 1930 to 2002 and are not directly comparable to statistics developed for a different period (Wiley, 2006).

Correlation coefficients were determined for each pair of streamgages for those 82 years of record and compared to the average number of days when flow at one streamgage of the pair (the estimator streamgage) exceeded one of three selected flow duration values-D75, D60, or D50 (the index flow) - but flow at the other streamgage of the pair (the estimated streamgage) did not exceed the D75 (table 13, at end of report). This tests how frequently an incorrect estimate would be made of whether D75 was exceeded if one streamgage of each pair was to be used as an index for the other. For this comparison, published annual values of D50, D60, and D75 representative of 1930 to 2002 were used (Wiley, 2006).

Incorrect estimates of flow would have been made even between pairs of streamgages with the strongest correlations (fig. 12). Numbers of incorrect estimates differed depending on which streamgage of the pair was the estimator streamgage and which was the estimated streamgage. Incorrect estimates were made less frequently by using the D60 as an index flow rather than the D75 and, in turn, by using the D50 as the index flow rather than the D60. Variances between Spearman's rho and incorrect estimates were generally less at relatively high levels of Spearman's rho ( $>0.85)$. The most accurate 82-year average estimates based on exceedances of the D75 were 7.7 and 9.2 days per year with incorrect estimates for a pair of streamgages with a correlation coefficient of 0.9696 (table 13). The most accurate 82-year average based on exceedances of the D60 were 0.1 and 1.2 days per year with incorrect estimates for the same pair of sites, and the most accurate 82-year average based on exceedances of the D50 was 0.1 day for two pairs of sites - the previously mentioned pair of sites and a second pair of sites with a correlation coefficient of 0.9601 . For selected threshold values of rho of $0.95,0.90$, and 0.85 , the least accurate estimates were, respectively, 11.4, 19.8, and 25.4 days per year, or 3.1, 5.4, and 6.9 percent, for estimates made from exceedances of the D75; 2.0, 4.8, and 9.5 days per year, or $0.6,1.3$, and 2.6 percent, for estimates made from exceedances of the D60; and 1.0, 2.64, and 5.7 days per year, or $0.3,0.7$, and 1.6 percent, for estimates made from exceedances of the D50.

Linear regression equations were developed to relate rho and days of incorrect estimates using each of the three flow duration values (table 14; fig. 12). These equations can be used to estimate the frequency of incorrect estimates of flow using the three flow duration values as index flows among stream sites with known or estimated levels of correlation. For selected threshold values of rho of $0.95,0.90$, and 0.85 , the rates of incorrect estimation of flow exceeding the annual D75 predicted from the regression equations were 3.9, 4.9, and 5.9 percent, respectively, when using the D75 as the index flow; $0.4,1.2$, and 1.9 percent when using the D60 as the index flow; and $0.02,0.5$, and 1.0 percent when using the D50 as the index flow.

At the highest flow correlation levels that were observed $(>0.95)$, estimates from the regression equation for the D50 index flow are less than the observations. However, the error rate predicted by the regression equation using the D60 as the index flow for a correlation of rho of 0.95 is 0.4 percent, which may be conservative enough for many purposes.

Table 14. Regression equations and diagnostics relating incorrect estimation of the 75-percent flow duration value at three selected index flows to correlation of daily flows for 15 selected streamgages in West Virginia, 1930-2011.

$\left[\mathrm{R}^{2}\right.$, coefficient of determination; $\mathrm{P}$, probability value; $\mathrm{D} 75,75$-percent flow duration; D60, 60-percent flow duration; D50, 50 percent flow duration; rho, Spearman's rho; <, less than]

\begin{tabular}{cccc}
\hline Index flow & Regression equation & $\mathbf{R}^{2}$ & $\mathbf{P}$ \\
\hline D75 & $y=-0.206551($ rho $)+0.234892$ & 0.9325 & $<0.001$ \\
D60 & $y=-0.153122($ rho $)+0.149549$ & 0.9010 & $<0.001$ \\
D50 & $y=-0.097988($ rho $)+0.093265$ & 0.7789 & $<0.001$ \\
\hline
\end{tabular}



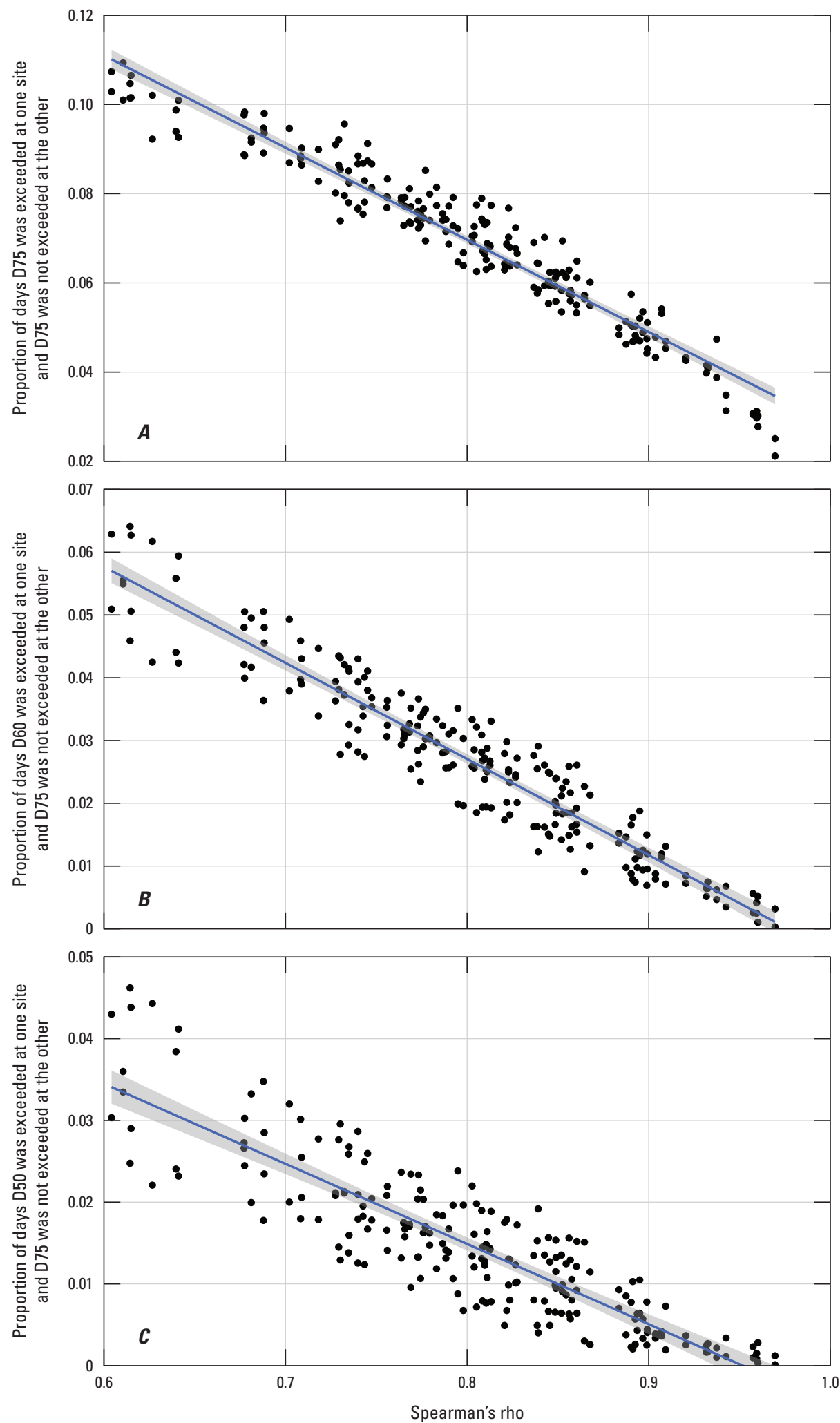

Figure 12. Proportion of days when flow at one site of a pair exceeded the $A, D 75, B, D 60$, and $C$, D50 and flow at the other site was less than the D75 in relation to Spearman's rho correlation coefficient for daily flows with line of regression and confidence interval for 15 selected streamgages in West Virginia, 1930-2011. 


\section{Relation of Flow Correlation and Record Length}

Annual flow correlations were computed for all pairs of sites from the set of 45 streamgages in and near West Virginia with nearly complete flow records for water years 1930-2011. Correlations were computed for the entire 82-year period and for all possible subsets of 1-, 2-, 5-, 10-, 20-, and 40-year periods. For the 1-year subset, a correlation matrix was generated for all pairs of sites for all 82 years, 1930-2011. For the 2-year subset, a correlation matrix was generated for all 42 2 -year periods beginning with an even-numbered year. For the 5 -year subsets, a correlation matrix was generated for the 16 5-year periods during 1930-2009, beginning with 1930-1934. For the 10 -year subsets, 8 correlation matrices were generated for the 10-year periods during 1930-2009, beginning with 1930-1939; 4 correlation matrices were generated for 20 -year subsets in the same way, as were 2 correlation matrices for 40-year subsets.

Simple linear regression between correlations of the subsets and 82-year correlations for all pairs of streamgages in this group showed decreasing variability with increasing length of the subset period. The coefficients of determination $\left(\mathrm{R}^{2}\right)$ for the relations of the 1-, 2-, 5-, 10-, 20-, and 40-year subset correlations to the 82-year correlations were 0.431 , $0.627,0.782,0.891,0.945$, and 0.980 , respectively. The relations of the 2-, 5-, and 10-year subset correlations to the 82-year correlations (fig. 13) show that subsets are different from each other even with increasing record length. Variation among time periods is generally greater in the range of values representing pairs of sites with weak correlations, but variation is substantial even at rho greater than (>) 0.90 .

These relations indicate that substantial uncertainty exists as to whether correlations determined between streamgages with relatively short $(<5$ years) periods of concurrent record represent long-term correlation. However, because relations among streamgages change over time, it is unclear that the longest-term periods of record are representative of present conditions.

In an attempt to balance spatial resolution and temporal variability, streamflow records of different lengths are used in this report for different purposes. Correlation coefficients for flow for entire years, as opposed to seasons, are presented for all pairs of streamgages with at least 1 year of concurrent record during 1930-2011, as is the number of days of concurrent record between each pair (tables 10-11). For delineation of the extent of expected correlations of flow at ungaged stream sites with flow at active streamgages and for evaluation of discontinued streamgages as candidates for reactivation to fill spatial gaps in the present streamgaging network, spatial resolution of historic correlation is critical. Short-term streamgages are included in map correlation analysis to maximize spatial resolution, even though the correlations to other streamgages might not be representative of long-term correlations. For analyses intended to identify patterns, exploratory analysis was done with pairs of streamgages with different lengths of record to determine whether including or excluding short-term streamgages clarified patterns; some of the analyses included in this report excluded short-term streamgages. Record lengths of streamgages included in different analyses are given with the discussion of those analyses.

\section{Relation between Flow Correlation and Distance}

Spearman's rho for all pairs of streamgages with at least one concurrent year of record was plotted as a function of the distance between basin centroids (fig. 14). Distance between centroids was square-root transformed because the relation between the highest values of rho and distance was linear after transformation. Quantile regression equations were developed for the 25th, 50th, 75th and 99th quantiles, (which are functionally equivalent to percentiles) using the $\mathrm{R}$ package quantreg (Koenker, 2013) and plotted to clarify patterns. Variance was greater among pairs of sites with correlations less than the 50th percentile (the median) relative to distance than among those with correlations greater than the median relative to distance.

Factors possibly affecting the relation between correlation and distance that were explored include length of record, streamgage location, basin size, and differences between distance between basin outlets (streamgage locations) and centroids. Effects of differences in distance between centroids and outlets are not shown but were negligible.

Variation in the relation between correlation and distance was greater among pairs of streamgages with short concurrent periods of record than among pairs of streamgages with long concurrent periods of record (fig. 15). For pairs of streamgages with 2 or fewer concurrent years of record $(n=9,684)$, correlations were both stronger and weaker relative to distance than for pairs of sites with 40 or more concurrent years of record $(n=9,326)$; although not shown, the variation in the relation between distance and correlation for pairs of sites with intermediate periods of concurrent record generally decreased as record increased. Much of the difference in variation between short-term and long-term streamgages is likely related to year-to-year differences in flow correlation, as shown with the subsets of long-term record at 15 selected streamgages (fig. 13). However, the populations of short-term and longterm streamgages are different. Long-term streamgages may be operated for many purposes, but among them is characterization of regional hydrology (Bales and others, 2004). In contrast, many short-term streamgages were operated as part of an interpretive study designed to characterize the effects of landuse change, management practices, or unique conditions, so that they were selected specifically because they were unrepresentative of regional conditions. Some of the streamgages with one or no correlations with any other streamgage exceeding 0.90 , though they were near other streamgages, were identified as having been operated during a short-term interpretive study. Among these are Robinson Run near Petroleum (0315520; Ward and others, 1991), Trace Fork at Ruth (03198020) 

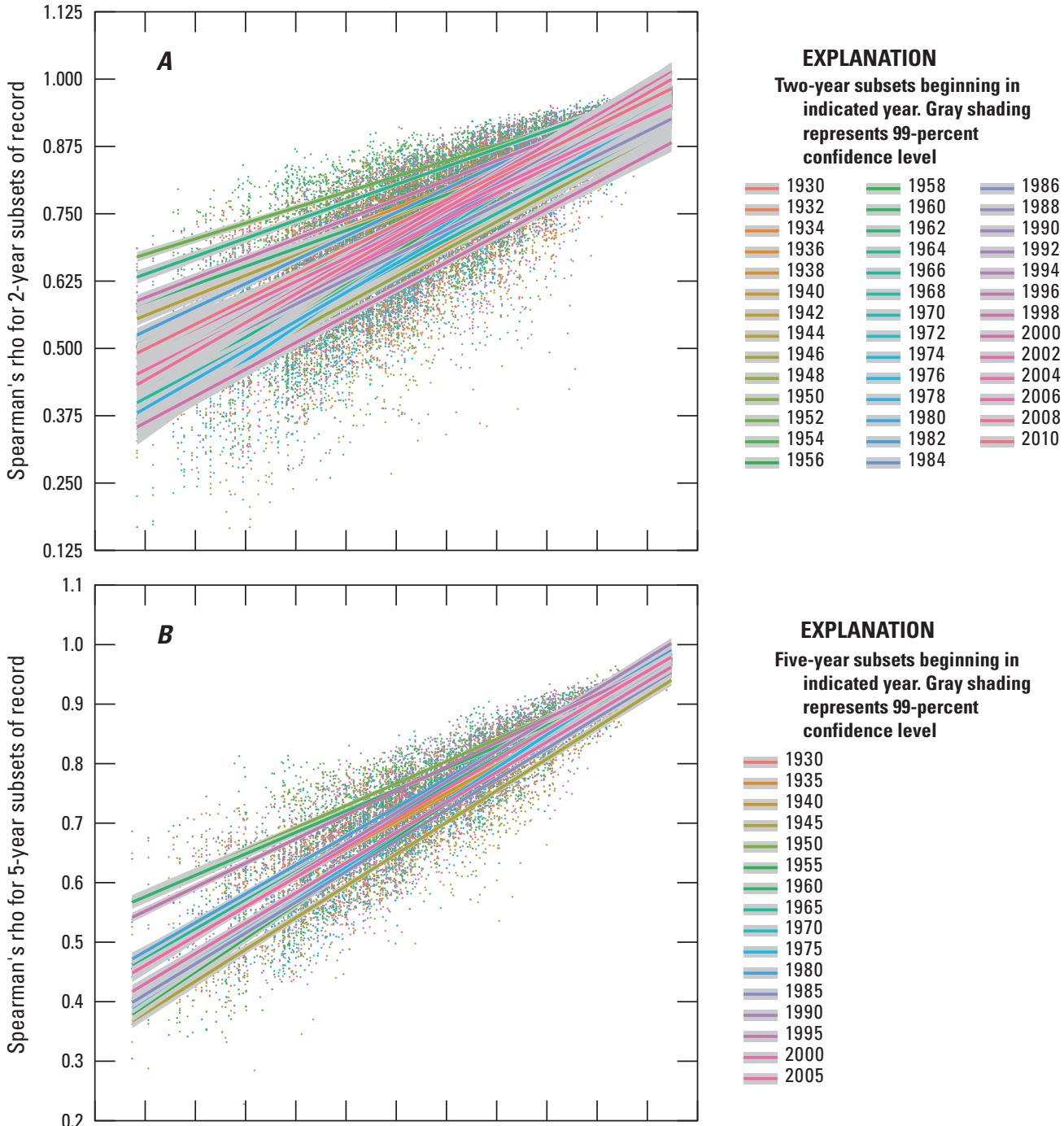

\section{EXPLANATION \\ Five-year subsets beginning in indicated year. Gray shading represents 99-percent} confidence level

$$
\begin{aligned}
& 1930 \\
& 1935 \\
& -1940 \\
& 1945 \\
& 1950 \\
& \text { - } 1955 \\
& -1960 \\
& \begin{array}{r}
-1965 \\
\hline-1970
\end{array} \\
& 1970 \\
& 1975 \\
& \text { - } 1980 \\
& 1985 \\
& 1990 \\
& 1995 \\
& 2000 \\
& 2005
\end{aligned}
$$

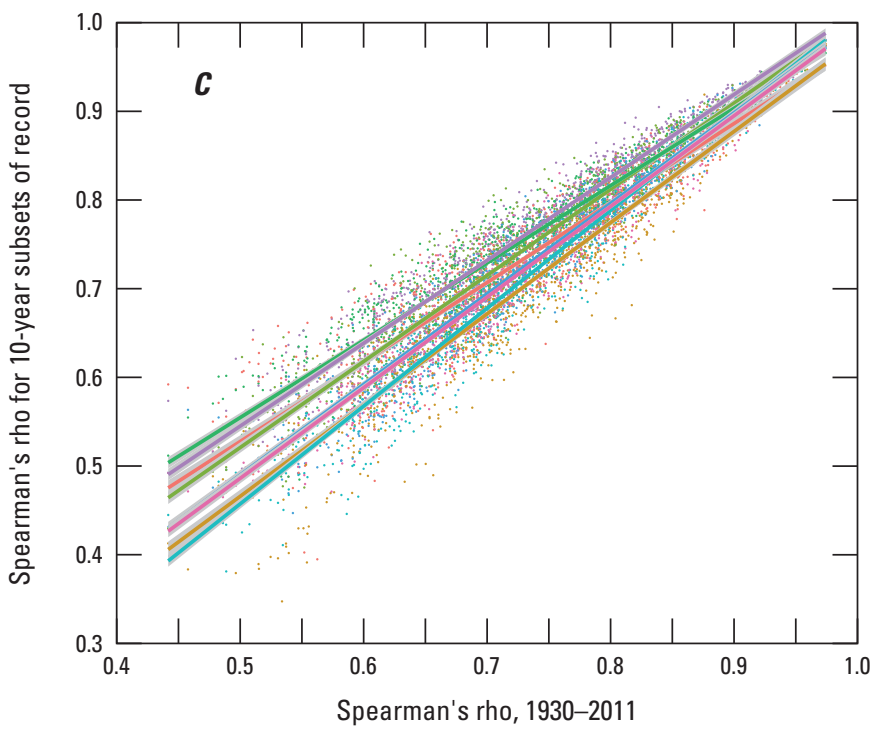

EXPLANATION

Ten-year subsets beginning in indicated year. Gray shading represents 99-percent confidence level

Figure 13. Relation of flow correlation for A, 2-year, B, 5-year, and C, 10-year subsets to flow correlation for the entire period of record for 15 selected streamgages in West Virginia, 1930-2011. 


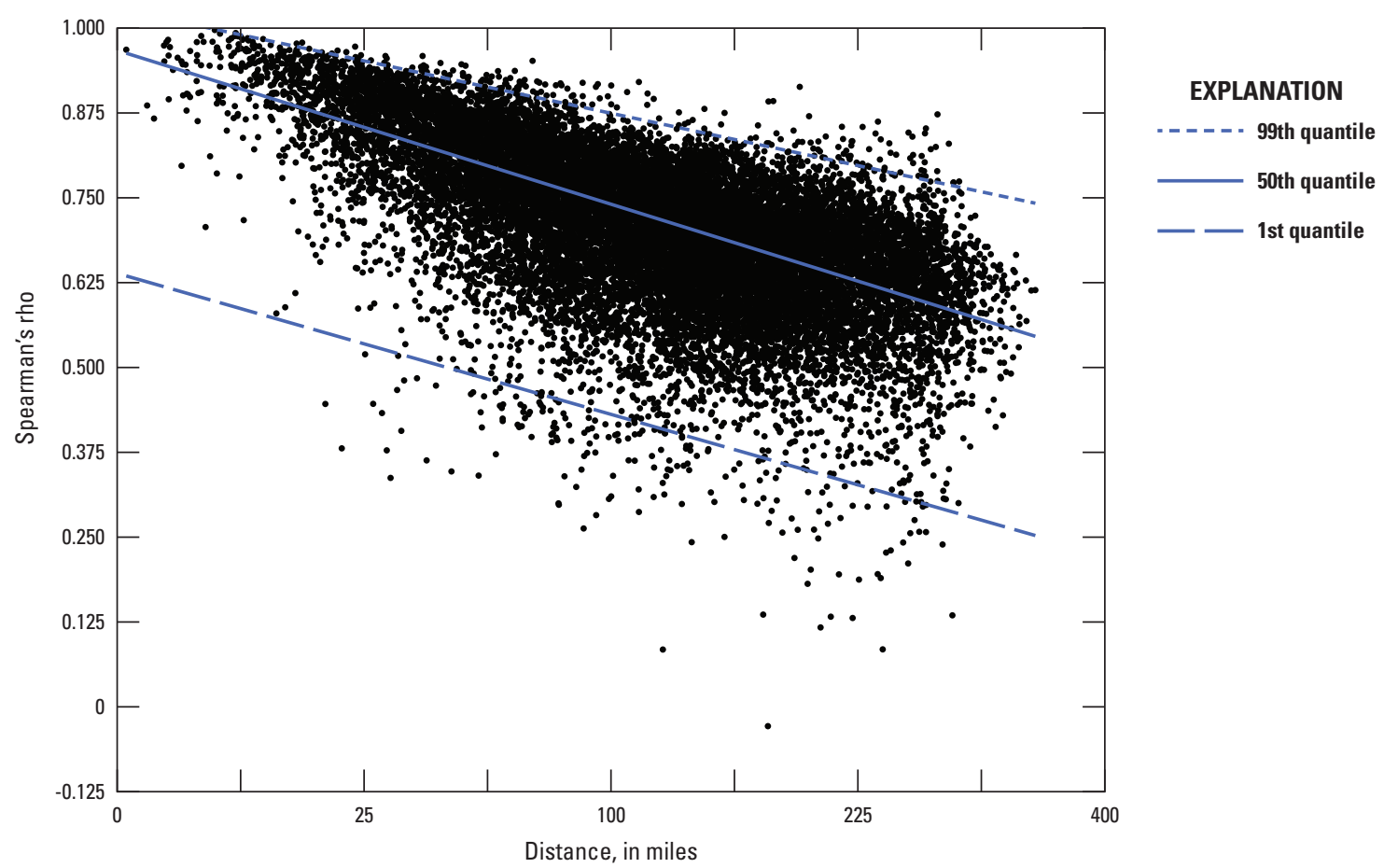

Figure 14. Relation of distance between basin centroids to correlation coefficients of daily flow for pairs of streamgages in and near West Virginia, 1930-2011, with regression lines for the 99th, 50th, and 1st quantiles.

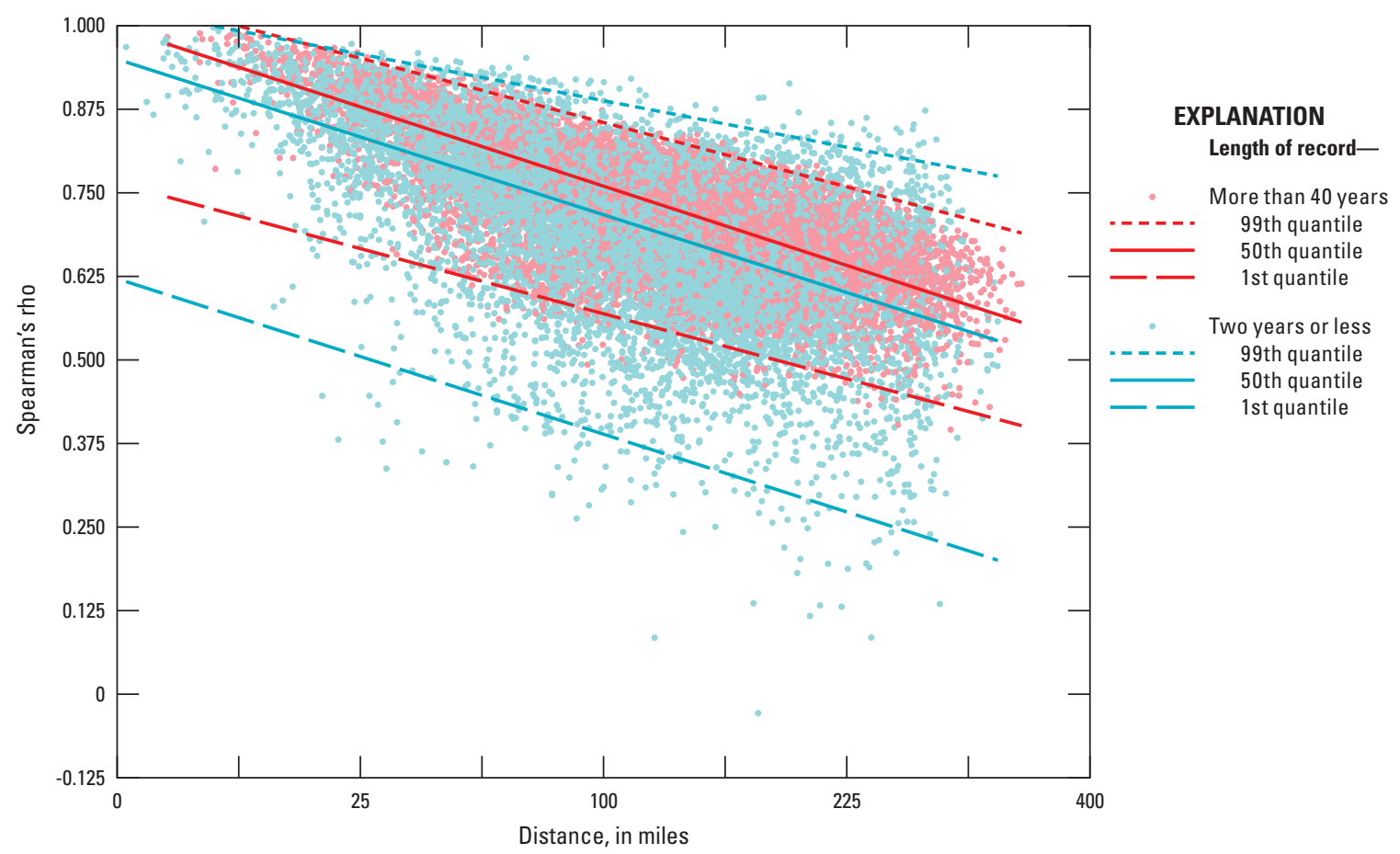

Figure 15. Relation of distance between basin centroids to correlation coefficients of daily flow for pairs of streamgages with more than 40 years of record to pairs of streamgages with fewer than 2 years of record in and near West Virginia, 1930-2011, with regression lines for the 99th, 50th, and 1st quantiles. 
and Trace Fork downstream from Dryden Hollow at Ruth (03198022; Downs and Appel, 1986), Unnamed Tributary of Ballard Fork near Mud (03204205; Messinger and Paybins, 2003), Johns Knob Branch near Elkhorn (03212640; Kozar and others, 2013), and Elkhorn Creek Tributary at Welch (03212703; Scott, 1984), all in West Virginia.

The relation between location and correlation was analyzed for pairs of streamgages with 10 or more years of concurrent record following exploratory analysis that included pairs of streamgages with shorter concurrent records. This length of record was selected because it is the shortest period of record for which patterns were evident when relations among all pairs of streamgages were compared; pairs of streamgages with 1, 2, 5, 10, and 20 years of record were compared.

The relation between correlation and centroid distance was stronger for pairs of streamgages in the Ohio River Basin $\left(R^{2}=0.6758, n=9,148\right)$ than in the Atlantic Slope River Basins $\left(R^{2}=0.3162, n=4,813\right)$ or for pairs of streamgages in which one streamgage was in one basin but the other streamgage was in the other basin $\left(R^{2}=0.2221, n=13,109\right.$; fig.16; referred to as "streamgages compared across major basins"). Although the overall relation did not fit a linear model well, linear regression was used to estimate variance among the three pairs of streamgages. Quantile regressions for the 99th, 50th, and 1st quantiles were developed for each set of data. Median quantile regressions for the Ohio River Basin and Atlantic Slope River Basin were outside the 99-percent confidence interval for their respective linear regression, although this was not the case for the streamgages compared across major basins.

The differences in the relations between correlation and distance for major basins are likely related to physiography. Within the study area, the Ohio River Basin is predominantly in the Appalachian Plateaus Physiographic Province, and the
Atlantic Slope River Basins are predominantly within the Valley and Ridge Physiographic Province. Streams in the Appalachian Plateaus are characterized by dendritic drainage patterns. Weather systems tend to cross the area from west to east, and though they are affected by orographic uplift, weather systems generally face few barriers until they cross the mountains. In the Valley and Ridge province, stream drainages are trellised. Precipitation from individual weather systems often varies more between valleys than within valleys. Streamgages compared across major basins likely have the weakest relation among the three groups that were compared because of the pronounced rain shadow that, for the most part, coincides with the division between the Atlantic Slope and Ohio Basins and the division between physiographic provinces.

Quantile regression equations were developed for the 99th, 75th, 50th, and 25th quantiles to determine the relation between distance and correlation for the Atlantic Slope and Ohio River Basins and for the relation between the two major basins; all equations are significant ( $\mathrm{p}<0.000001$; table 15$)$. These equations can be used to estimate typical, excellent, or poor relations that could be expected between pairs of streams at various distances within the study area for the purpose of streamgage network analysis.

For a distance of 50 miles between basin centroids, the 99th quantile of Spearman's rho of 0.9128 for the Ohio River Basin represents the strongest correlation seen among sites, and only 1 percent of ungaged sites would be expected to relate to an index streamgage this strongly. The Spearman's rho predicted by quantile regression for the 50th quantile, or median, 0.8472 , is typical of the correlation among sites at this distance, and the Spearman's rho predicted by quantile regression for the 25 th percentile, 0.8140 , represents the correlation likely to be observed between at least 75 percent of paired sites with centroids 50 miles apart. For the Ohio River Basin, the distance between centroids at which 50 percent

Table 15. Quantile regression equations and standard errors for the 25th, 50th, 75th, and 99th quantiles of the relation between distance and Spearman's rho correlation coefficient among pairs of streamgages for the Atlantic Slope and Ohio River Basins in and near West Virginia, 1930-2011.

[All equations are significant at $\mathrm{P}<0.00001 ; \mathrm{SE}$, standard error; $\mathrm{D}$, distance in miles; $<$, less than]

\begin{tabular}{|c|c|c|c|c|c|c|}
\hline \multirow{2}{*}{ Streamgage pair } & \multicolumn{3}{|c|}{ 25th quantile } & \multicolumn{3}{|c|}{ 50th quantile } \\
\hline & Equation & SE, intercept & SE, slope & Equation & SE, intercept & SE, slope \\
\hline Ohio River Basin & $1.006-0.0271\left(\mathrm{D}^{-0.5}\right)$ & 0.0028 & 0.0003 & $1.028-0.0256\left(\mathrm{D}^{-0.5}\right)$ & 0.0019 & 0.0002 \\
\hline Atlantic Slope River Basins & $0.91-0.0176\left(\mathrm{D}^{-0.5}\right)$ & 0.0069 & 0.0007 & $0.968-0.0185\left(\mathrm{D}^{-0.5}\right)$ & 0.0031 & 0.0004 \\
\hline Cross-basin pairs & $0.763-0.0114\left(\mathrm{D}^{-0.5}\right)$ & 0.0045 & 0.0003 & $0.841-0.0134\left(\mathrm{D}^{-0.5}\right)$ & 0.0038 & 0.0003 \\
\hline \multirow{2}{*}{ Streamgage pair } & \multicolumn{3}{|c|}{ 75th quantile } & \multicolumn{3}{|c|}{ 99th quantile } \\
\hline & Equation & SE, intercept & SE, slope & Equation & SE, intercept & SE, slope \\
\hline Ohio River Basin & $1.044-0.0244\left(\mathrm{D}^{-0.5}\right)$ & 0.0015 & 0.0002 & $1.057-0.0204\left(D^{-0.5}\right)$ & 0.0022 & 0.0003 \\
\hline Atlantic Slope River Basins & $0.987-0.0167\left(\mathrm{D}^{-0.5}\right)$ & 0.0029 & 0.0003 & $1.017-0.014\left(\mathrm{D}^{-0.5}\right)$ & 0.0041 & 0.0005 \\
\hline Cross-basin pairs & $0.907-0.0147\left(\mathrm{D}^{-0.5}\right)$ & 0.0038 & 0.0003 & $1.012-0.0163\left(\mathrm{D}^{-0.5}\right)$ & 0.0141 & 0.0011 \\
\hline
\end{tabular}



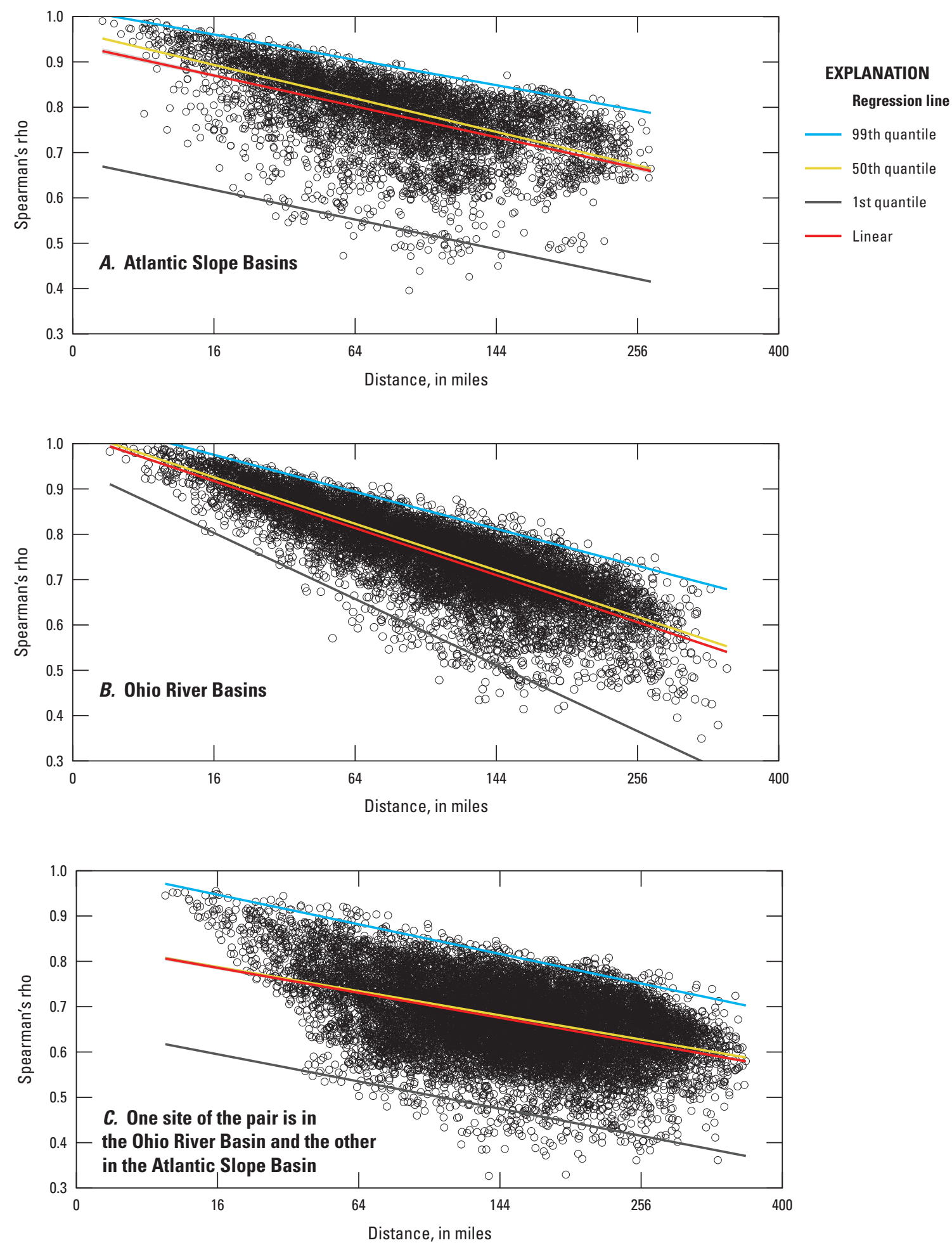

Figure 16. Relation of distance between basin centroids to correlation of daily flows among streamgages, with 10 or more years of concurrent records, on unregulated streams in the $A$, Atlantic Slope Basin, $B$, the Ohio River Basin, and $C$, one streamgage each in the Atlantic Slope and Ohio River Basins, in and near West Virginia, 1930-2011, and linear and 99th, 50th, and 1st quantile lines of regression. 
of streamgage pairs would exceed a Spearman's rho of 0.95 is 9 miles. The distance at which 50 percent of streamgages would exceed a Spearman's rho of 0.90 is 25 miles, and the distance at which 50 percent of streamgage pairs would exceed a Spearman's rho of 0.85 is 48 miles. For the Atlantic Slope River Basins, the distance between centroids at which 50 percent of streamgage pairs would exceed a Spearman's rho of 0.95 is 1 mile. The distance at which 50 percent of streamgages would exceed a Spearman's rho of 0.90 is 13 miles, and the distance at which 50 percent of streamgage pairs would exceed a Spearman's rho of 0.85 is 41 miles. For streamgages compared across major basins, the median quantile regression line crosses the $y$-axis at a value of 0.84 , indicating that less than one-half of streamgage pairs compared across major basins at any distance would be expected to have correlation coefficients of about 0.84 ; the plot in figure 16 shows that this regression is strongly affected by a preponderance of streamgage pairs with basin centroids separated by 25 miles or more and that, if the analysis were restricted to streamgage pairs closer to each other, a relation could be developed among the handful of adjacent, strongly correlated streamgage pairs.

\section{Spatial Patterns in Flow Correlation}

The difference in the relation between correlation and distance is reflected in correlation maps of daily flows, the maps that were developed by using ordinary kriging of correlation coefficients between basin centroids (figs. 17-20). The correlation maps were clipped to a polygon created by buffering the outline of West Virginia plus 25 miles so that all the correlation zones depicted on the maps are fully defined. A correlation map was developed for each unregulated streamgage within 50 miles of West Virginia that was active as of September 2012 and had more than 1 full year of flow data during 1930-2011. The maps show full-year correlations with all unregulated streamgages within 50 miles of West Virginia with which the selected stream shares at least 1 year of concurrent record during 1930-2011 (appendix 1, available for download at http://dx.doi.org/10.3133/sir20145061). This approach allows the areas of historic flow correlation to recently reactivated streamgages, including one that was reactivated in water year 2012, to be determined to evaluate them for use as index streamgages. The inclusion of short-term streamgages resulted in the inclusion of more areas of weak correlation than of strong correlation because the relation between correlation and distance is weaker for the short-term streamgages than for the long-term streamgages (fig. 15).

Spatial correlation patterns for streamgages in the Appalachian Plateaus appear to be generally related to elevation and mean annual precipitation (fig. 19). For Buffalo Creek at Barrackville (streamgage 03061500), the zone of strongest correlation (rho $>0.90$ ) was approximately circular with the streamgage centroid near the center of the zone; the zone of second strongest correlation (rho $>0.85$ ), although not round in shape, encompasses areas with generally similar ranges of elevation (fig. 2). For Big Coal River at Ashford (streamgage 03198500; fig. 18) in southern West Virginia and in the Appalachian Plateaus, spatial correlation patterns are generally similar to those for Buffalo Creek. The zone of strongest correlation is approximately circular, and the basin centroid for the streamgage is near the center of the zone. The zone of correlation between rho 0.85 and 0.90 for Big Coal River is generally centered at the basin centroid, although there is an area of low correlation to the south.

In comparison, the zone of strongest correlation for Blackwater River at Davis (streamgage 03066000; fig. 19) located in the Appalachian Plateaus province but near the border with the Valley and Ridge province, and in some of the highest elevations of the study area, conforms to areas similar in elevation and precipitation as the Blackwater River Basin. Zones of strongest correlation trend from southwest to northeast, as do the Allegheny Mountains. The areas of stronger correlation to this streamgage extend farther to the west into the Appalachian Plateaus province and within the Ohio River Basin than to the east and into the Valley and Ridge province. The zone of strongest correlation for Blackwater River includes streamgages on two tributaries to the North Branch Potomac River Basin within the Appalachian Plateaus.

The zones of strongest correlation to South Branch Potomac River at Franklin (streamgage 01605500) are oblong and, like those for Blackwater River, trend southwest to northeast (fig. 20). The zone of strongest correlation for this streamgage on the South Branch Potomac River extends farther to the north, along the river, than to the south, across the basin divide into the James River Basin and to some eastern tributaries of the Greenbrier River; it extends farther to the east, into the Valley and Ridge province and the South Fork South Branch Potomac River Basin, than to the west across the basin and physiographic divides.

A set of summary maps was developed that depict the number of active streamgages with correlation zones at each grid point in the study area that have a correlation value greater than thresholds of rho of $0.95,0.90$, and 0.85 (figs. 21-23). Little of West Virginia (6 percent) is within zones correlated with any streamgage above the threshold of rho 0.95; these areas are generally in river basins in which several streamgages have been operated along the same stream. Most of West Virginia (77 percent) is within zones correlated with at least one active streamgage at greater than the threshold of rho of 0.90 , and much of West Virginia (32 percent) is within zones correlated at greater than this threshold with five or more active streamgages. Only a small area within West Virginia ( $<1$ percent) is outside areas correlated with any active streamgage at greater than the threshold of rho of 0.85 , and most of West Virginia (88 percent) is within areas correlated with five or more streamgages at greater than rho of 0.85 .

Two areas with the weakest correlations are in western West Virginia and the eastern tip of West Virginia (fig. 23). The eastern area contains several active streamgages that are weakly correlated with each other (table 10). This area is underlain by karst, which probably affects flow timing and 

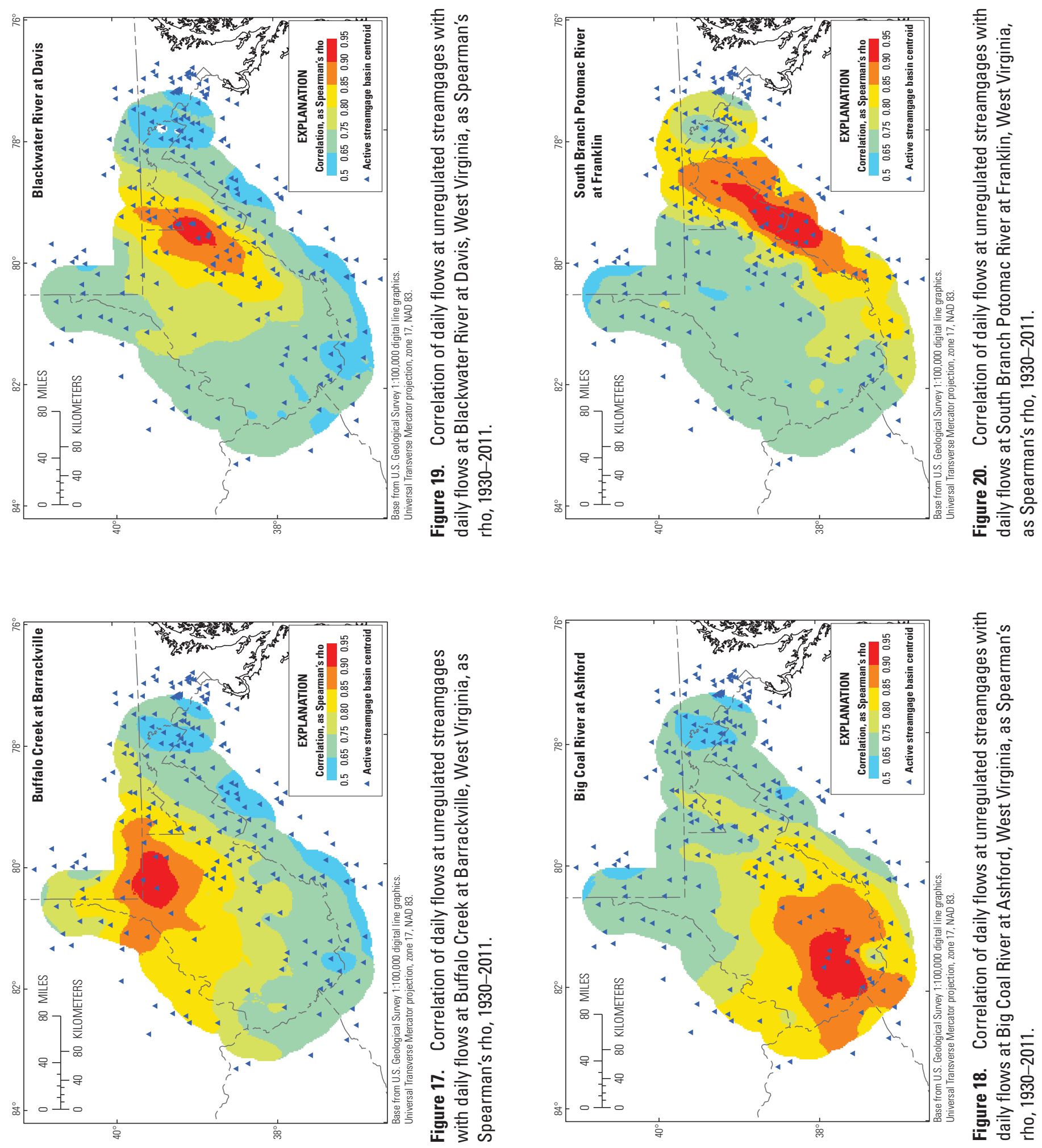

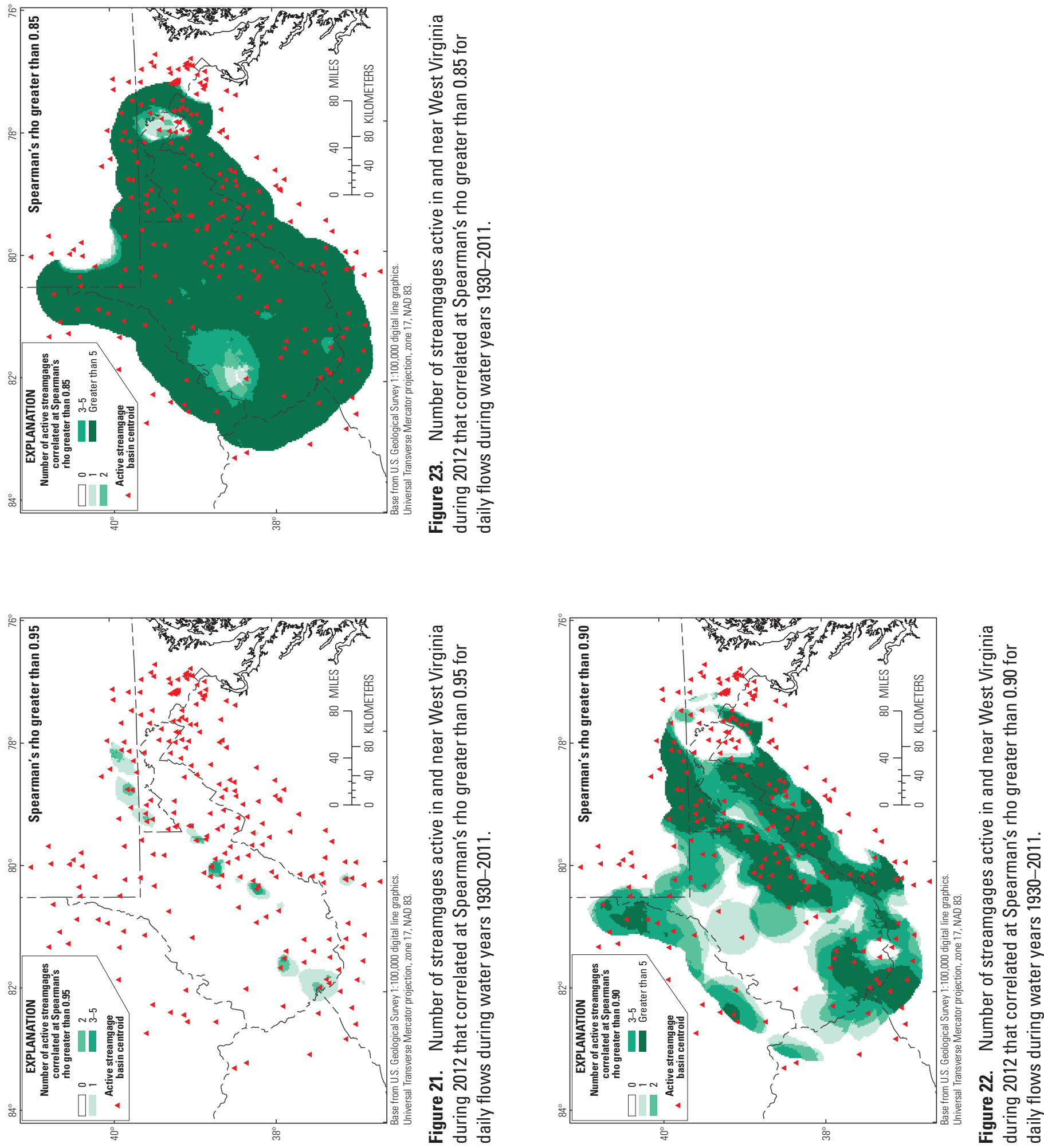
magnitude, and streamgages in this area, although near other streamgages, generally are poorly correlated among each other. The weak correlations depicted on correlation maps for the western area are likely an artifact of streamgage distribution. This area contains one active streamgage, Hurricane Creek near Hurricane (streamgage 03201405), which began operating in 1998. During 1998-2012, it was among the most spatially isolated streamgages in the West Virginia network. One historical streamgage, Poplar Fork at Teays (streamgage 03201410), was operated near this area during the 1970s; it was correlated at values of rho $>0.85$ with three now discontinued streamgages and had correlation coefficients generally similar to those for Hurricane Creek with those streamgages that were in operation during both the 1970s and 1998-2012 (table 10).

Two areas in southern West Virginia are outside correlation zones where rho is greater than 0.90 with any active streamgage (fig. 22). One area is approximately bisected by the New River and represents an area where few streamgages have ever been operated. The other area, near the southern tip of West Virginia, was the location of several historical streamgages, including Johns Knob Branch near Elkhorn (streamgage 03212640; Kozar and others, 2013) and Elkhorn Creek Tributary at Welch (streamgage 03212703; Scott, 1984), previously identified as short-term streamgages operated to characterize hydrologic alteration, in this case, alteration resulting from coal mining. Although the hydrology of this area may be unique because it represents the southernmost and most updip limit of coal mining in West Virginia (Kozar and others, 2013), it may instead be an example of a cluster of small streams affected by a land use, coal mining, in ways that are different from the effects on large streams.

\section{Seasonal Differences in Flow Correlation}

The strength and extent of correlation varies with season (tables 16-19, available for download at $h t t p: / / d x . d o i$. $\operatorname{org} / 10.3133 / \mathrm{sir} 20145061)$. The extent of correlation at a threshold of rho $>0.90$ is less in each season than for a full year (figs. 24-27; appendixes 2-5, available for download at http://dx.doi.org/10.3133/sir20145061). The strongest and most extensive correlations are for fall (October 1-December 31) when 72 percent of West Virginia is within a zone with correlation of rho $>0.90$ to one or more active streamgages (fig. 24). Flows are generally at their lowest during late summer and early fall. Precipitation is dominated by frontal systems, and large areas receive similar amounts of rain at about the same time. Slow, soaking rain events with a broad extent cause generally similar streamflow responses from large and small basins (Black, 1991).

Correlation strength and extent are the next strongest during winter. Most (62 percent) of West Virginia is within correlation zones where at least one streamgage had a correlation greater than rho of 0.90 (fig. 25). Areas of correlation are different during winter than during fall. Precipitation type often varies greatly with elevation, with the same storm system producing rain in the lowlands but snow in the mountains. Timing of snowmelt also varies greatly with elevation, as does the freezing of streams and soil. Correlations for spring generally are weaker and less extensive than are correlations for winter. Less than one-half (42 percent) of West Virginia is within correlation zones where at least one streamgage had a correlation $>0.90$ (fig. 26). During spring, dominant precipitation patterns shift from frontal systems to convective events. Within areas with generally similar elevation and temperature, convective storms cause uneven precipitation distribution. For summer, correlations between pairs of streamgages were found to be $>0.90$ in very little of West Virginia ( 3 percent; fig. 27). By summer, precipitation is dominated by convective thunderstorms. Rainfall is frequently scattered or isolated. A moderate rise on a medium-size stream may be caused by rain received in a tributary basin and is frequently not accompanied by rises on nearby streams. Once convective storms have begun, runoff from different streams may vary greatly even during large frontal systems that produce generally uniform amounts of rain throughout the region because antecedent conditions may differ according to which areas received prior rain from thunderstorms. These phenomena result in correlations for summer being the weakest and least extensive among correlations for all seasons.

Not only does the strength of correlation vary among seasons, but the relative ranking of correlations among sites also varies by season. As shown by the summary maps, the specific areas with strong correlations for active streamgages change seasonally in response to weather patterns (figs. 24-27).

Because correlations among streamgages change greatly with season, selection of index streamgages made on the basis of seasonal correlations could be more accurate than selection made on the basis of annual correlation, particularly if predictions regarding seasonal statistics are desired.

Seasonal and annual correlations computed from all full years of data for the 391 unregulated streamgages operated in and near West Virginia during 1930-2011 were compared for their concurrent periods of record (fig. 28). Correlations between the annual and each of the four seasonal correlation coefficients were weak but were especially so for those pairs of streamgages with less than 5 years of concurrent record. Comparison of the 99th and 1st quantile regression lines computed for the relation between the seasonal and annual correlations for the pairs of sites with 5 or more years of concurrent record and those computed for sites with less than 5 years of concurrent record shows much more variation for the pairs of streamgages with shorter records. Many of the correlation coefficients for short-term streamgages were higher than those determined among pairs of streamgages with long periods of record; the 50th quantile (median) regression line for the pairs of short-term streamgages plotted higher than that for the pairs of long-term streamgages for the entire range of values for fall and all but the highest annual correlations for winter and summer but slightly lower for spring. Variation in the relation between seasonal and annual correlations 

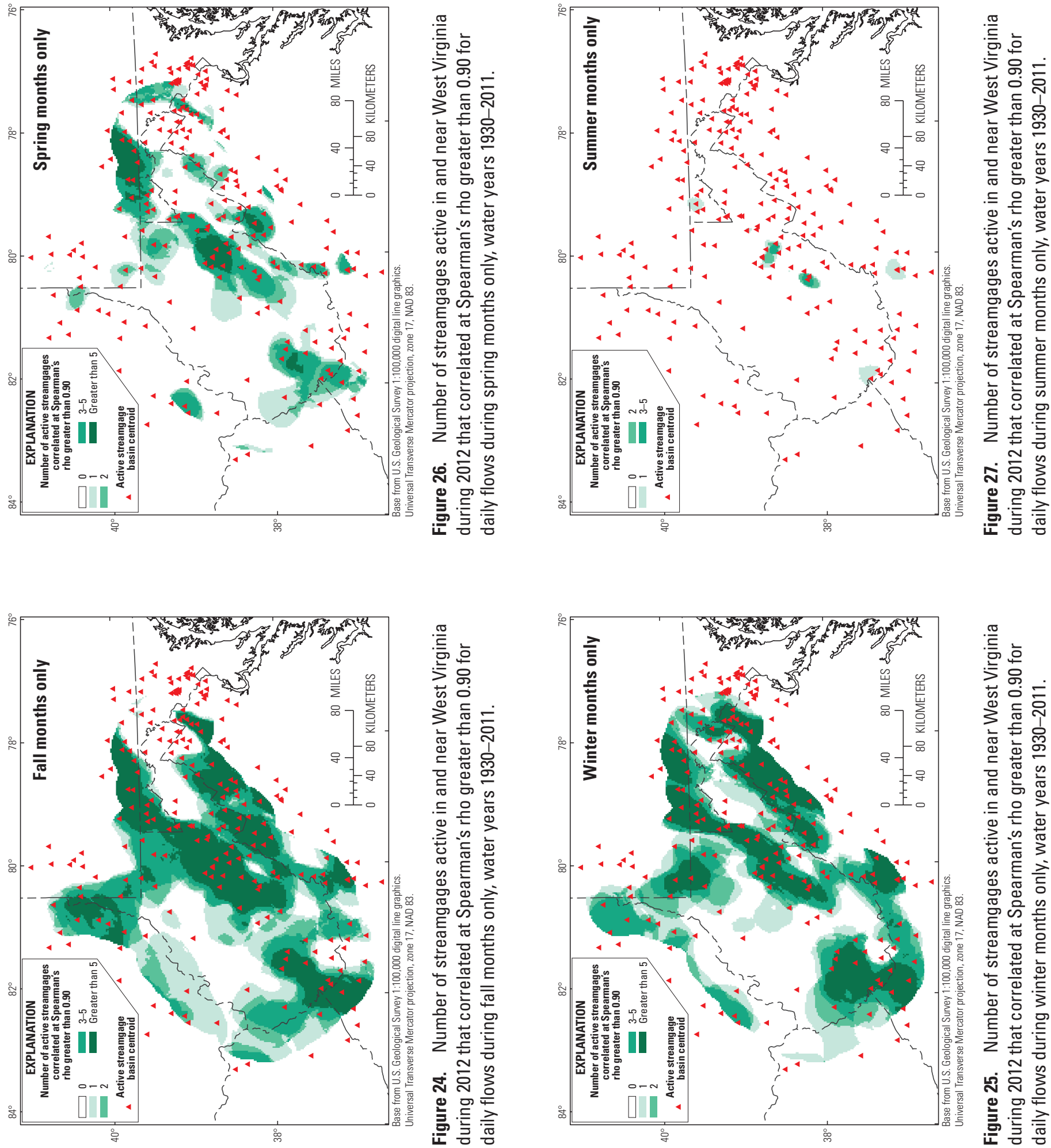

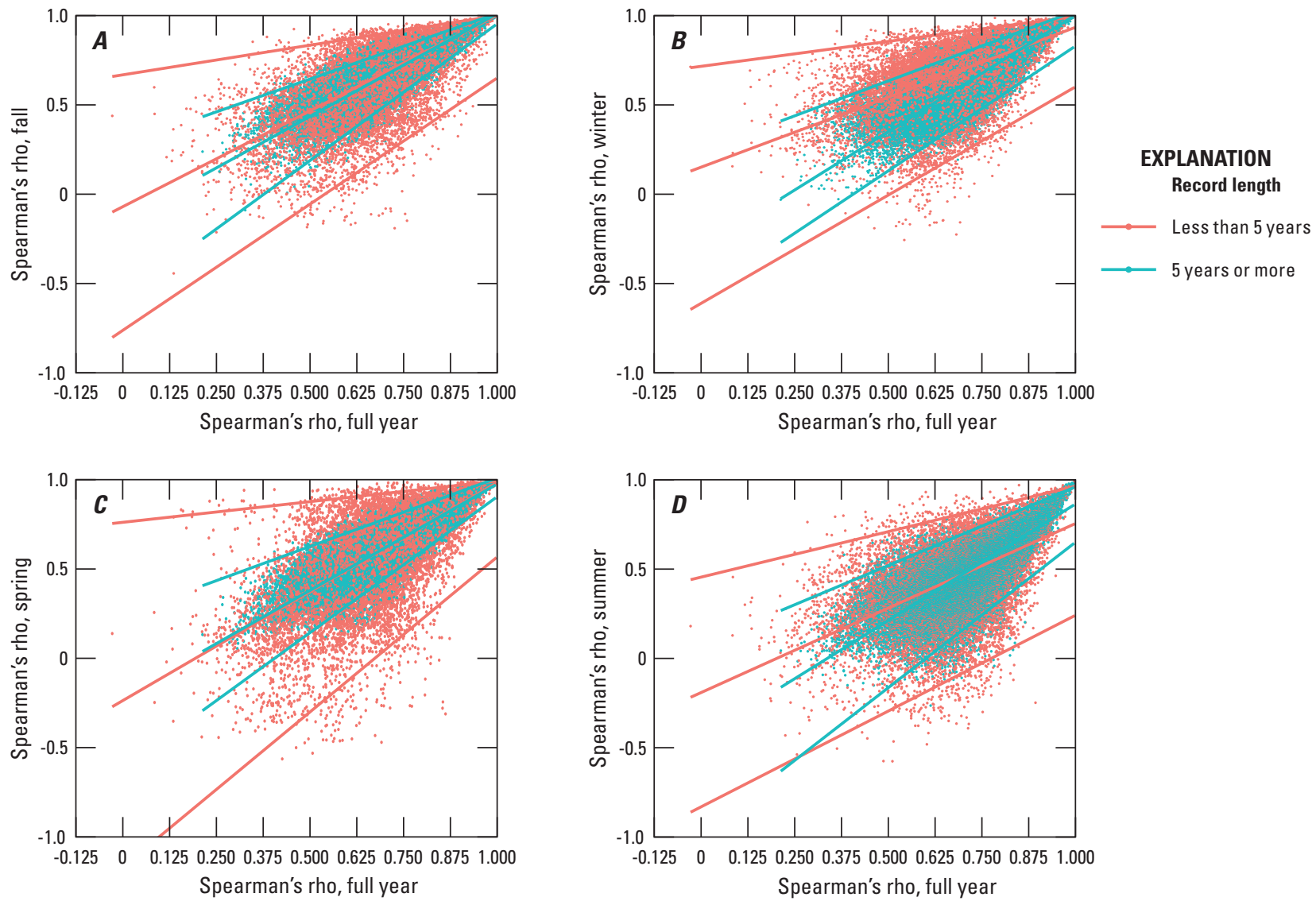

Figure 28. Relation of correlation coefficients of daily flow for the full year to that of $A$, fall, $B$, winter, $C$, spring, and $D$, summer at 391 selected streamgages in and near West Virginia, 1930-2011.

among the pairs of short-term (less than 5 years of concurrent record) streamgages, however, was much greater than among the pairs of long-term streamgages; $\mathrm{R}^{2}$ values for short-term and long-term pairs of streamgages, respectively, were 0.4538 and 0.8092 for fall, 0.2920 and 0.7218 for winter, 0.4181 and 0.7778 for spring, and 0.2714 and 0.6097 for summer.

\section{Decadal Differences in Flow Correlation}

A comparison was made among correlation maps for the 1963-1969, 1970-1979, and 1992-2011 groups of streamgages (appendixes 6-8, available for download at $h t t p: / /$ $d x$.doi.org/10.3133/sir20145061). The overall period of about 1960-1980 was of interest because the streamgaging network in West Virginia was at or near its maximum number of streamgages, and analysis of this period could provide information on the spatial extent of flow correlation that might be expected if a streamgage were to be reactivated. Because the periods 1963-1969 and 1970-1979 were climatically distinct, they were analyzed separately from each other. The 20 -year period preceding the study, 1992-2011, was selected to represent recent conditions. Correlation values for streamgage pairs with 1 year or more of concurrent record were determined for the period of interest. Spearman's rho matrices for each of the three periods (tables 20-22) were prepared; cross-correlation was determined for each pair of streamgages. Correlation maps for the three time periods were prepared and summarized as described previously. Examples of predicted correlations of daily streamflow at selected streamgages with flow at Middle Island Creek at Little, WV, are shown in figures 29-31 for each period.

Long-term differences in the strength, extent, and pattern of streamflow correlations are related to long-term climate variation and changes in the streamgaging network. The strongest and most extensive correlation patterns found in this study were for 1963 to 1969 , a period of historic drought, rather than 1970 to 1979 , the wettest extended period on record for West Virginia, but the 1963-1969 period overlapped with the 1970-1979 period when the greatest number of streamgages was active on unregulated streams in West Virginia (figs. 32 and 33). The 10-year running average for the number of unregulated streamgages in West Virginia was slightly greater for 1969-1978, 92.6, and 1968-1977, 92.5, than for 1970-1979, 91.7 (fig. 6). The numbers of streamgages operated outside West Virginia, but within the 50-mile buffer, 

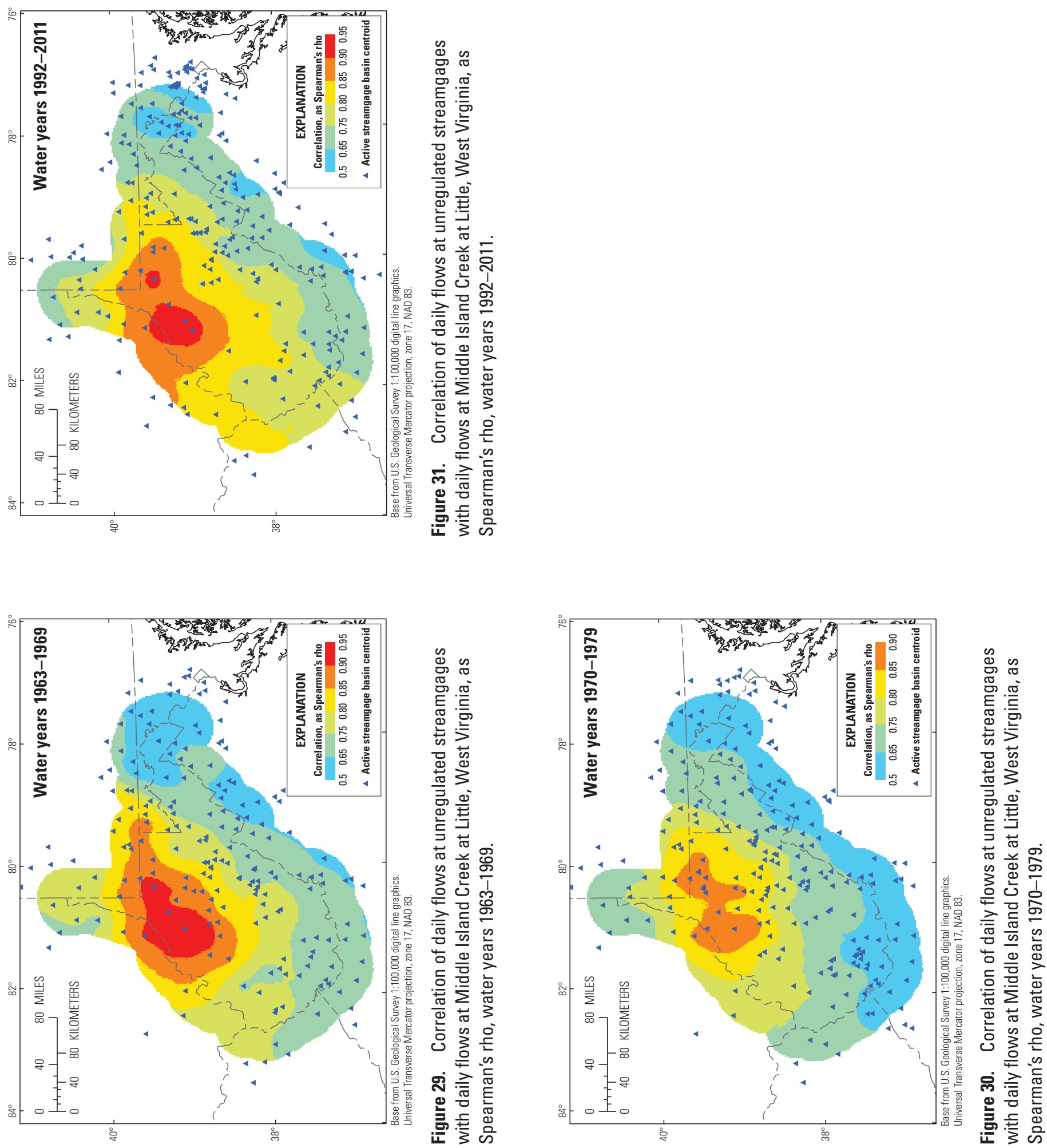
did not track the numbers operated inside West Virginia; overall numbers of streamgages included in the analysis were 198 for 1963-1969, 244 for 1970-1979, and 223 for 1992-2011.

As indicated by the correlation maps for 1963-1969, 1970-1979, and 1992-2011, patterns are related to the specific streamgages in operation at that time (figs. 32-34). Strength and spatial extent of flow correlation were greater during the 1963-1969 period, a time of drought, than during 1992-2011, a period when flows were more variable. Flow correlations for periods 1963-1969 and 1992-2011 were stronger and more extensive than flow correlations for the period 1970-1979.

During the 1963-1969 period, most (89 percent) of West Virginia was within zones correlated with at least one streamgage above a threshold of rho $>0.90$, and much $(29$ percent) of West Virginia was within zones correlated above that threshold with 10 or more streamgages. During the 1970-1979 period, less of West Virginia was within zones correlated with at least one streamgage above a threshold of rho $>0.90$ (68 percent) than during 1963-1969, and less of West Virginia (21 percent) was within zones correlated above that threshold with 10 or more streamgages. During the 1992-2011 period, about the same amount (29 percent) of West Virginia was within zones correlated with one or more streamgages above a threshold of rho $>0.90$ as during the 1970-1979 period, but slightly less (17 percent) of West Virginia was within zones correlated above that threshold with 10 or more streamgages.

Generally, the areas with the strongest correlations (Spearman's rho $\geq 0.95$ ) are in places with the greatest density of streamgages, in parts of the Cheat, Tygart Valley, Gauley, Coal, and Tug Fork River Basins. The parts of West Virginia where correlations are weaker (Spearman's rho $<0.90$ and $>0.85$ ) coincide with areas in western and west-central West Virginia and near the Kanawha River, where few streamgages are operated on unregulated streams. However, differences in correlation among sites throughout the year, and in response to climatic conditions, affect correlations among streamgages and therefore the extent of predicted correlation.

Even during 1970-1979, when West Virginia's streamgaging network included nearly double the number of unregulated streamgages that were active in 2011, large parts of West Virginia were likely to be only weakly correlated with one or more of the streamgages in the network at that time. This weak correlation could be caused by several factors. Climatic conditions seem likely to affect flow correlation. Although exploratory analysis relating various summaries of correlation to flow statistics found no relation, this might change if improved summary metrics for correlations were available.

Flow correlation is strongly related to the location and other characteristics of sites in the streamgaging network. Adding streamgages that are redundant with existing streamgages seems unlikely to do much to extend areas of flow correlation, as is evidenced by the large areas during the 1963-1969 period where 10 or more streamgages were strongly correlated. Adding streamgages in areas with few streamgages would be more likely to extend the range of flow correlation. Also, adding streamgages to disturbed or unusual areas, or at least understanding their flow characteristics, would be important because, if unaccounted for, small-scale local variability may result in poor flow estimates even if correlation maps indicate a homogeneous, strongly correlated area.

\section{Map Correlation and Possible Expansion of the Present Streamgaging Network}

The decadal-scale analysis was intended to take advantage of the greater density of unregulated streamgages during the period 1970-1979 than during any other time in the history of the West Virginia streamgaging network with the anticipation that correlations to the inactive or now-regulated streamgages would prove to be a convenient method to assess the manner in which their reactivation might enhance the existing network.

The summary correlation map for 1992-2011 shows correlation exceeding 0.90 for much of West Virginia (fig. 34). The average number of active, unregulated streamgages within West Virginia was 55 during 1992-2011 and increased to 62 during 2009-2011. Three streamgages were established or reactivated in parts of West Virginia with predicted correlations less than 0.90; Birch River at Herold (streamgage 03196500; figs. 18-19) in central West Virginia and new USGS streamgages East River at Willowton (streamgage 03177120) and Indian Creek at Red Sulfur Springs (streamgage 03177480) in southern West Virginia are located in these areas, although they are recent enough so that no final data were available for the present analysis. The largest remaining area with relatively low correlation is in western and west-central West Virginia.

Correlations maps are shown for West Fork Little Kanawha River at Rocksdale (streamgage 03154000), 1970 to 1979, and for Elk Creek near Quiet Dell (streamgage 03059500), 1963 to 1969 (fig. 35). Both are in or near an area where active streamgages are absent. The contemporary correlation map shows generally weak correlation to active streamgages. Gas wells have been completed in the Marcellus Shale. Elk Creek at Quiet Dell is in an area with extensive shale-gas development. West Fork at Little Kanawha River at Rocksdale is in an area with shale-gas development, although its strongest zones of correlation include areas where many vertical but few horizontal gas wells have been completed in the Marcellus Shale.

The streamgage West Fork Little Kanawha River at Rocksdale (03154000) showed historically strong correlations with several presently discontinued or currently regulated streamgages in central West Virginia (tables 10, 16-22). The discontinued streamgages at Pocatalico River at Sissonville and Reedy Creek near Reedy (streamgages 03201000 and 03154500, respectively) were near the West Fork Little Kanawha River at Rocksdale, are strongly correlated with it, and have similar correlation maps. If reactivated, any of these 

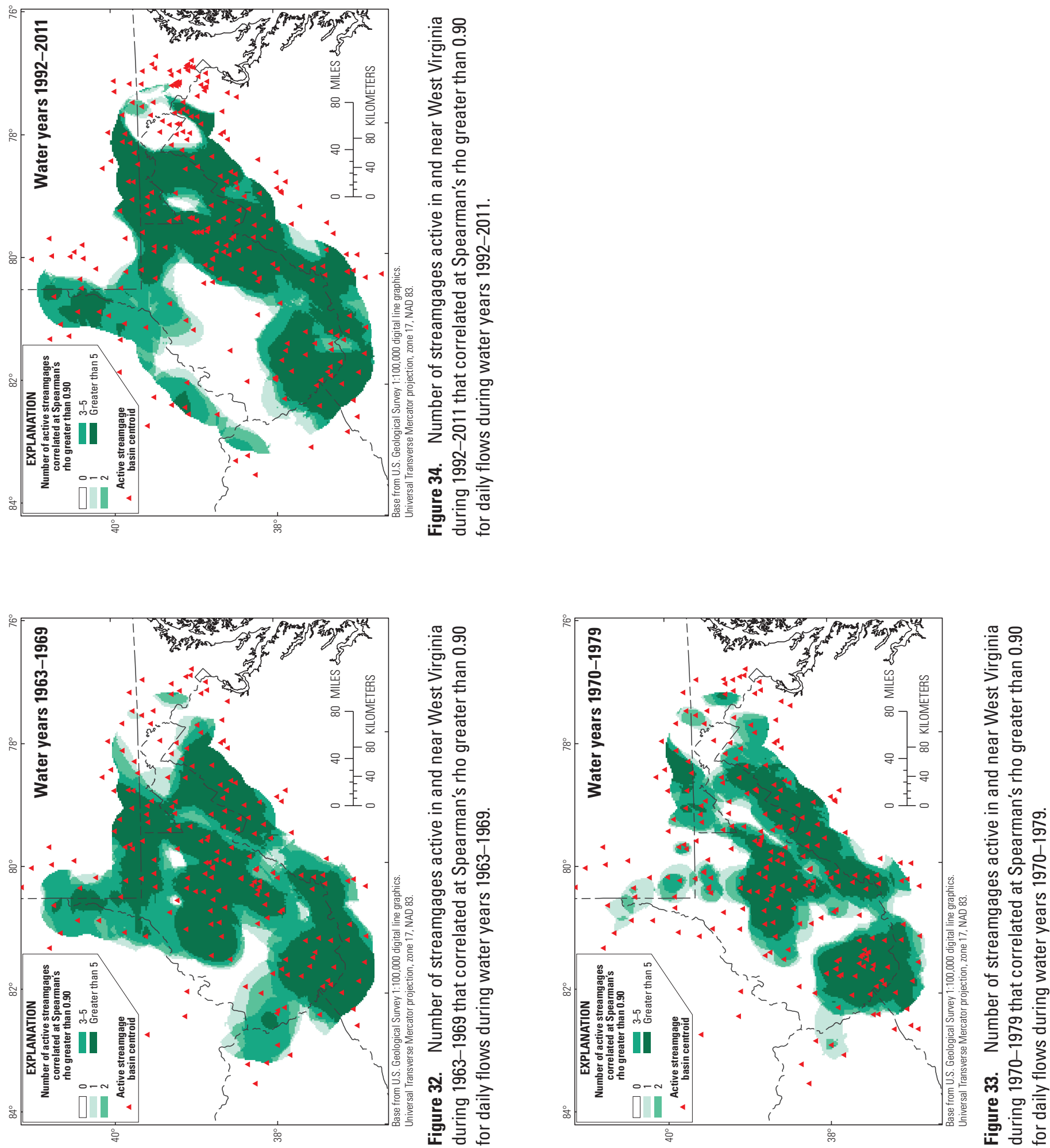


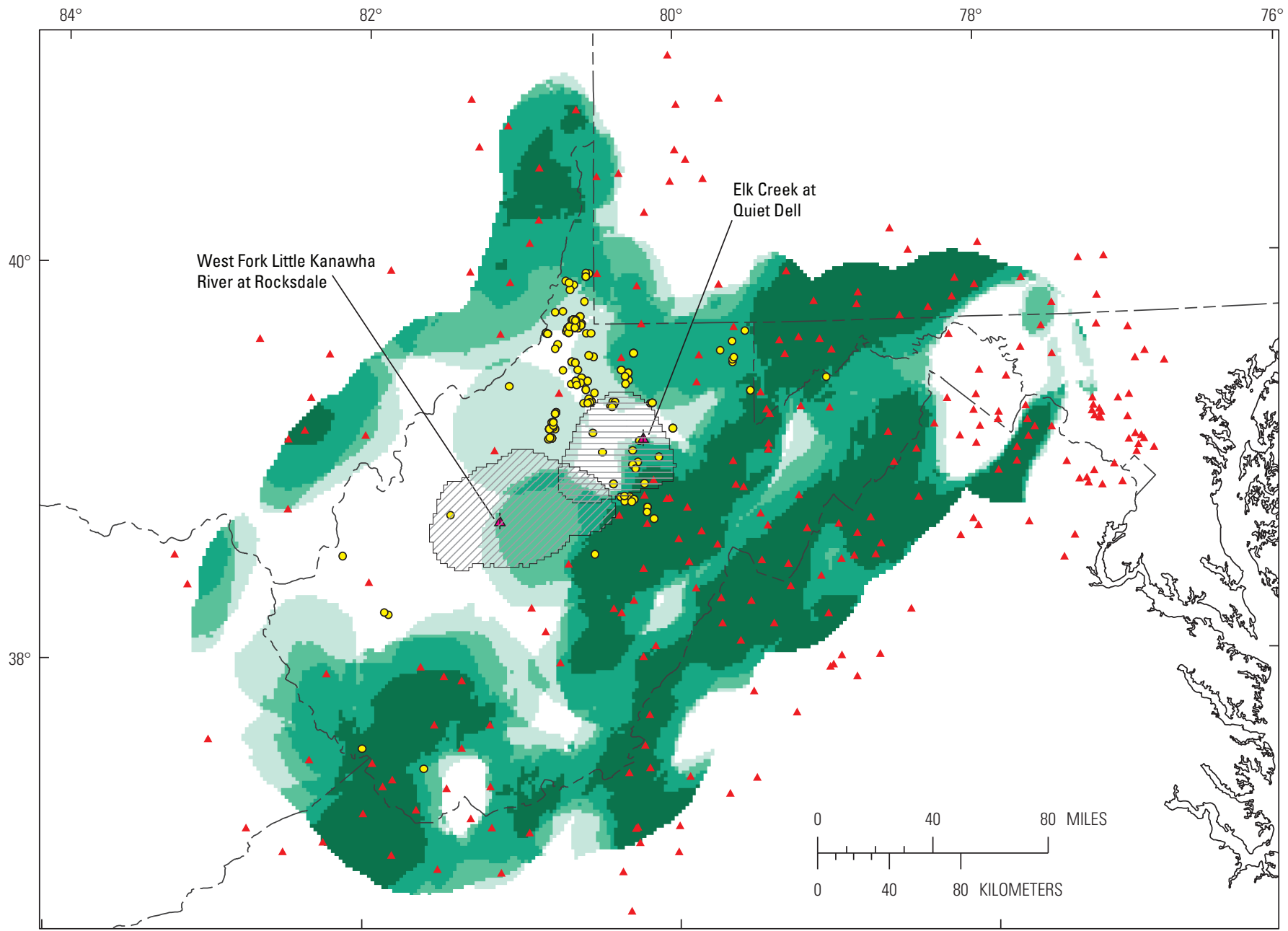

Base from U.S. Geological Survey 1:100,000 digital line graphics. Universal Transverse Mercator projection, zone 17, NAD 83.

\section{EXPLANATION}

Correlation with Elk Creek at Quiet Dell at Spearman's rho greater than 0.90

\begin{tabular}{|c|c|}
\hline WIII & $\begin{array}{l}\text { Correlation with West Fork Little Kanawha } \\
\text { River at Rocksdale at Spearman's rho } \\
\text { greater than } 0.90\end{array}$ \\
\hline & $\begin{array}{l}\text { Number of active streamages correlated } \\
\text { at Spearman's rho greater than } 0.90\end{array}$ \\
\hline & 0 \\
\hline & 1 \\
\hline & 2 \\
\hline & $3-5$ \\
\hline & Greater than 5 \\
\hline$\Delta$ & Active streamgage basin centroid \\
\hline 4 & $\begin{array}{l}\text { Basin centroid of discontinued streamgage } \\
\text { considered for reactivation }\end{array}$ \\
\hline 0 & Completed horizontal Marcellus Shale gas \\
\hline
\end{tabular}

Figure 35. Number of streamgages active in and near West Virginia during 2012 that correlated at Spearman's rho greater than 0.90 for daily flows during water years 1930-2011, historic correlation to two discontinued streamgages, and horizontal Marcellus Shale gas well completed through 2012. 
streamgages could fill a gap in the network. The historic correlation maps for West Fork Little Kanawha River at Rocksdale shows slightly better agreement with the areas where the 1992-2011 summary map shows no areas of predicted high correlation. Additionally, continuous stage data are already being collected there (as of 2013), so that the West Fork Little Kanawha River at Rocksdale streamgage could be reactivated at less expense than other streamgages.

If an additional index streamgage is needed specifically for managing withdrawals for hydraulic fracturing in the area undergoing Marcellus Shale development, Elk Creek near Quiet Dell (streamgage 03059500) would be a strong candidate for reactivation. It is within map zone 50 , one of the map zones discussed previously that refers to an unrepresentative streamgage (table 4). Although it is probably less suitable than West Fork Little Kanawha River at Rocksdale for filling a spatial gap in the overall network, Elk Creek near Quiet Dell, discontinued in 1969, had correlations of rho greater than or equal to $(\geq) 0.90$ with several other streamgages in the West Fork Basin that are now regulated or discontinued. Among active streamgages, it had correlations near rho of 0.90 with two unregulated streamgages, Tygart Valley River at Belington (streamgage 03051000) and Buffalo Creek at Barrackville (streamgage 03061500). Other discontinued streamgages in the general area had lower maximum correlations or were closer to presently active streamgages.

An area in northwestern West Virginia has heavy shalegas development but demonstrated neither correlation greater than rho 0.90 to active streamgages nor a promising discontinued streamgage to evaluate for reactivation. A discontinued streamgage on the fringes of the area, Buffalo Run near Little (streamgage 03114650), did not have strong correlations with any other streamgages (maximum rho 0.8603). Part of this area is in WWGT map zone 48, which was previously identified as a map zone that receives 10 percent more annual precipitation than the basin of its index streamgage (table 4). Withdrawals in this area could be managed by requiring a conservative index flow, directly measuring flows when appropriate, a combination of these, or establishing a new streamgage and determining areas to which it is correlated.

Outside the area of active shale-gas development, with little demand for water from small ungaged streams, flow estimates derived from an index streamgage with average daily flow correlations of rho $\geq 0.85$ might meet most needs. If additional spatial resolution in the streamgaging network is desired, however, western West Virginia includes areas with relatively low correlations. Hurricane Creek near Hurricane (streamgage 03201405; table 1) is the most isolated streamgage in the network; its two nearest neighbors, both with centroids 35 miles away from the Hurricane Creek centroid, are East Fork Twelvepole Creek near Dunlow (streamgage 03206600) and Coal River at Tornado (streamgage 03200500). The Hurricane Creek streamgage has a maximum correlation of Spearman's rho 0.85 with East Fork Twelvepole Creek near Dunlow; Mud River near Milton (streamgage 03204500) is roughly halfway between these two streams. Mud River near Milton has been regulated since 1980, and the streamgage would not be a good candidate for reactivation. A streamgage on a different stream in this area would increase spatial resolution.

South Fork Hughes River below MacFarlane (03155220) is the second most isolated streamgage in the network; its nearest neighbor, among presently unregulated streamgages, is Middle Island Creek at Little (03114500). Their centroids are 30 miles apart, and Spearman's rho is 0.9445 . If West Fork Little Kanawha River at Rocksdale is reactivated, it would become the nearest neighbor for the South Fork Hughes River streamgage with basin centroids 24 miles apart. The area northwest of West Fork Little Kanawha River at Rocksdale and between South Fork Hughes River below MacFarlane and Hurricane Creek at Hurricane (03201405) has a limited number of historic streamgages. A new streamgage about 20 miles southwest of South Fork Hughes River near MacFarlane and a new streamgage about 20 miles north or northeast of Hurricane Creek at Hurricane would be useful additions to fill spatial gaps in the streamgaging network. These areas were previously identified (Runner and others, 1989; Straub, 1998) as being in need of additional streamgages on small streams for regional analysis, particularly for low flows.

The correlation maps for 1970 to 1979 frequently show more detailed, and in some cases different, patterns than the maps for the other periods (fig. 30, appendix 7). These correlation maps could prove to be valuable in future regional regression analyses of streamflow characteristics or for designing networks of partial-record sampling or measurement sites.

\section{Limitations of the Study}

Correlations of daily flows for summer are much weaker than for the rest of the year, and accurate estimates of flow for ungaged sites using index streamgages are unlikely. Direct measurement of streamflow, including by reference to a stage-discharge rating, is likely to be necessary to determine flow accurately on an ungaged stream during summer in West Virginia.

Map correlation provides little if any insight into managing regulated streams. The effects of basin alterations, other than dams and diversions, on map correlations may be great. As an example, summary correlation maps for active streamgages show a zone of decreased correlation in southern West Virginia (figs. 18, 22, 24, 25) that centers around Johns Knob Branch near Elkhorn (03212640), a small stream receiving a large interbasin transfer through an underground coal mine (Kozar and others, 2013). As another example, correlation maps displayed throughout this report show a decreased zone of correlation in the eastern tip of West Virginia (figs. 20, $22,23,25,32-34)$; this zone results from weak correlations for small streams in that area, including March Run at Grimes, MD (01617800), and Tuscarora Creek above Martinsburg, WV (01617000), that drain an area of karst (table 10). Other 
special conditions likely exist in which streams within an area of a certain predicted correlation do not conform to regional expectations. Because these conditions exist in many areas where streams have not been gaged, correlation maps cannot incorporate them, and accurate flow estimates are likely to be made in such areas only if users account for these conditions.

The present analysis is intended to identify spatial gaps or redundancies in the streamgaging network but only for the specific use of estimating streamflow in real time. Correlation of daily flows, and its spatial distribution, provides information relevant to the selection of regionally representative index streamgages, but it does not provide all information relevant to designing a streamgaging network that meets the other needs of the streamgaging program. Other purposes of the streamgaging network are, to varying degrees, independent of this use. This study has not considered correlation of extreme high- and low-flow values, which may not conform to the correlation of daily values and are the most important flow characteristics for many regulatory, design, and planning purposes. Other approaches exist to evaluate the streamgaging network for these purposes (Kiang and others, 2013). Although index streamgages on relatively large streams appear to provide accurate estimates of flow in real time for small, ungaged streams, the need remains for streamgages on small (drainage area $<20 \mathrm{mi}^{2}$ ) streams in order to determine low-flow characteristics identified by Runner and others (1989). The present study does not address the use of streamgages for operation of dams, intakes, or other facilities, and it provides little, if any, information to address regional flood characteristics. Highly correlated streamgages may meet important operational or other needs for the USGS and its partner agencies and, therefore, do not necessarily become lower priorities for inclusion in the streamgaging network.

\section{Summary and Conclusions}

To provide information needed to manage water withdrawals from ungaged streams, the U.S. Geological Survey (USGS), in cooperation with the West Virginia Department of Environmental Protection, has evaluated correlations of daily flow among active and discontinued streamgages and the spatial distribution of those correlations. Correlations of daily flows among unregulated streamgages were determined using Spearman's rho. Correlation coefficients between pairs of streamgages were determined for 82 years of record and compared to the average number of days when flow at one streamgage of the pair (the estimator streamgage) exceeded one of three selected flow duration values, the 75 percent (D75), 60 percent (D60), and 50 percent (D50; the index flow), but the other streamgage of the pair (the estimated streamgage) did not exceed the D75. Regression equations were developed to relate Spearman's rho values and number of days of incorrect estimates using each of the three flow durations. For selected threshold values of rho of 0.95, 0.90, and 0.85 , the respective rates of incorrect estimation of the number of days flow exceeded the annual D75, predicted from the regression equations, were $3.9,4.9$, and 5.9 percent when using the D75 as the index flow; $0.4,1.2$, and 1.9 percent when using the D60 as the index flow; and 0.02, 0.5, and 1.0 percent when using the D50 as the index flow.

Relations between correlation and distance between basin centroids differed between the Ohio River Basin and the Atlantic Slope River Basins. For the Atlantic Slope River Basins, the relation between distance and correlation was weaker and more variable than for the Ohio River Basin. In the Ohio River Basin, the highest correlation that might be expected between streamgages with basin centroids 50 miles apart, determined by a regression of the 99th quantile, was a Spearman's rho of 0.9128. In the Ohio River Basin, onehalf of streamgages with basin centroids 50 miles apart have Spearman's rho values of 0.8472 or more, and 75 percent of streamgages with basin centroids 50 miles apart have Spearman's rho values of 0.8140 or more. For the Ohio River Basin, the distance between centroids at which 50 percent of streamgage pairs would exceed a Spearman's rho of 0.95 is 9 miles. The distance at which 50 percent of streamgage pairs would exceed a Spearman's rho of 0.90 is 25 miles, and the distance at which 50 percent of streamgage pairs would exceed a Spearman's rho of 0.85 is 48 miles. For the Atlantic Slope River Basins, the distance between centroids at which 50 percent of streamgage pairs would exceed a Spearman's rho of 0.95 is 1 mile. The distance at which 50 percent of streamgages would exceed a Spearman's rho of 0.90 is 13 miles, and the distance at which 50 percent of streamgage pairs would exceed a Spearman's rho of 0.85 is 41 miles. For pairs of streamgages in which one of the pair is in the Ohio River Basin and the other is in the Atlantic Slope River Basins, the relation between correlation and distance is weaker than for streamgages within either major basin, and the 50th quantile regression equation predicts a correlation of 0.84 at a distance of zero.

In the Appalachian Plateaus province outside the Allegheny Mountains, zones of strongest correlation to streamgages are generally round and approximately centered at the basin centroid. In the Allegheny Mountains, zones of strongest correlation are related to patterns in elevation and annual precipitation, and follow the trend of the mountain range. In the Valley and Ridge province, zones of strongest correlation follow valleys. Correlation across the crest of the mountains is generally weak. Most of West Virginia (77 percent) is within map zones where Spearman's rho for daily streamflow to at least one existing unregulated streamgage is greater than 0.9, and most withdrawals from ungaged streams for hydraulic fracturing are being made in these areas. Most of the rest of West Virginia ( $>99$ percent, cumulatively) is within zones where Spearman's rho to existing unregulated streamgages is greater than 0.85 . Regulated withdrawals were made from ungaged streams in the latter areas, but assuming spatial correlation in these areas is similar to that in the rest of West Virginia, expected correlations could be increased to 0.90 or 
higher with several new or reactivated streamgages. Seasonal differences in the strength and extent of correlation in daily streamflow are great. The strongest correlations among streamgages occur during the fall, followed by winter, then spring, and correlations in summer are weak. One possible explanation for the weaker correlation in summer may be the differences in precipitation and runoff associated with convective storms. Because convective storms generally are frequent and localized to small geographical areas, nearby basins often are not affected by the same storms. Field observations are likely to be necessary to confirm which streams rise in response to localized storms. A comparison of correlation patterns during previously identified climatic periods showed that the strongest correlations were found during 1963-69, a period of drought, and the weakest during 1970-79, a wet period. The apparent effect of frequent rain during 1970-79 overshadowed gaging network density, which was at its historic maximum in West Virginia. The extent of areas with high correlation to at least one streamgage was less during 1970-79 than during 1963-69. Correlations for the 1992-2011 period were slightly weaker than those for the 1963-1969 period.

Inclusion of some streamgages in areas where flow is known to be altered or regionally unrepresentative produced low correlations, and in turn, local zones of low correlation on the correlation maps. Because not all such areas include streams that have been gaged, correlation maps do not account for them. Highly correlated streamgages may meet different operational or other needs for the USGS and its partner agencies and do not automatically become lower priorities for inclusion in the streamgaging network.

\section{References Cited}

American Whitewater, 2013, West Virginia state rivers, accessed April 2, 2014, at http://www.americanwhitewater. org/content/River/state-summary/state/WV/.

Archfield, S.A., and Vogel, R.M., 2010, Map correlation method: Selection of a reference streamgage to estimate daily streamflow at ungaged catchments: Water Resources Research, no. 46, W10513, doi:10.1029/2009WR008481.

Archfield, S.A., Steeves, P.A., Guthrie, J.D., and Ries III, K.G., 2013, Towards a publicly available, map-based regional software tool to estimate unregulated daily streamflow at ungauged rivers: Geoscience Model Development, no. 6, p. 101-115, doi:10.5194/gmd-6-101-2013.

Archfield, S.A., Vogel, R.M., Steeves, P.A., Brandt, S.L., Weiskel, P.K., and Garabedian, S.P., 2010, The Massachusetts Sustainable-Yield Estimator: A decision-support tool to assess water availability at ungaged stream locations in Massachusetts: U.S. Geological Survey Scientific Investigations Report 2009-5227, 41 p., plus CD-ROM.
Austin, S.H., Krstolic, J.L., and Wiegand, Ute, 2011, Lowflow characteristics of Virginia streams: U.S. Geological Survey Scientific Investigations Report 2011-5143, 122 p., 9 tables on $\mathrm{CD}$.

Bales, J.D., Costa, J.E., Holtschlag, D.J., Lanfear, K.J., Lipscomb, S., Milly, P.C.D., Viger, R., and Wolock, D.M., 2004, Design of a National Streamflow Information Program-Report with recommendations of a committee: Reston, Va.: U.S. Geological Survey Open-File Report 2004-1263, $42 \mathrm{p}$.

Black, P.E., 1991, Watershed hydrology: Englewood Cliffs, N.J., Prentice Hall, 408 p.

Cardwell, D.H., Erwin, R.B., and Woodward, H.P., and Lotz, C.W., comps., 1968, Geologic map of West Virginia: West Virginia Geological and Economic Survey, 2 sheets, scale 1:250,000.

Carr, B.A., 2013, Annual progress report to the WV Joint Legislative Oversight Commission on State Water Resources: West Virginia Department of Environmental Protection Water-Use Section, accessed April 2, 2014, at http://www. dep.wv.gov/WWE/wateruse/Pages/WaterReourcesManagem entActProgressReports.aspx.

Doheny, E.J., and Banks, W.S.L., 2010, Selected low-flow frequency statistics for continuous-record streamgage locations in Maryland, 2010: U.S. Geological Survey Open-File Report 2010-1310, 22 p.

Downs, S.C., and Appel, D.H., 1986, Progress report on the effects of highway construction on suspended-sediment discharge in the Coal River and Trace Fork, West Virginia, 1975-81: U.S. Geological Survey Water-Resources Investigations Report 84-4275, $20 \mathrm{p}$.

Eggelston, J., 1996, History of WV mineral industries - oil and gas, accessed April 2, 2014, at http://www.wvgs.wvnet.edu/ www/geology/geoldvog.htm.

Esri, 2012, ArcGIS 10.1, build 3143, accessed April 2, 2014, at $h$ ttp://www.esri.com/software/arcgis/arcgis-for-desktop.

Falcone, J.A., Carlisle, D.M., Wolock, D.M., and Meador, M.A., 2010, GAGES-A stream gage database for evaluating natural and altered flow conditions in the conterminous United States: Ecology, no. 91, p. 621, accessed April 2, 2014, at http://esapubs.org/archive/ecol/E091/045/.

Fenneman, N.M., 1938, Physiography of Eastern United States: New York, McGraw-Hill, 714 p.

Fenneman, N.M., and Johnson, D.W., 1946, Physical divisions of the United States: U.S. Geological Survey Physiography Committee Special Map, scale 1:7,000,000. 
Frye, P.M., and Runner, G.S., 1970, A proposed streamflow data program for West Virginia: U.S. Geological Survey Open-File Report, unnumbered, 38 p.

Hobba, W.A., Jr., 1981, Effects of underground mining and mine collapse on the hydrology of selected basins in West Virginia: West Virginia Geological and Economic Survey Report of Investigation RI-33, 84 p.

Hydrometeorological Design Studies Center, 2006a, Isopluvials of 60 minute precipitation (inches) with average recurrence interval of 2 years, Delaware, District of Columbia, Maryland, New Jersey, Ohio, Pennsylvania, West Virginia: National Oceanic and Atmospheric Administration Atlas 14, volume 2, version 3, Ohio River Basin and Surrounding States, accessed April 2, 2014, at http://hdsc.nws.noaa.gov/ $h d s c / p f d s / p f d s \_m a p s . h t m l$.

Hydrometeorological Design Studies Center, 2006b, Isopluvials of 60 minute precipitation (inches) with average recurrence interval of 2 years, Illinois, Indiana, Ohio: National Oceanic and Atmospheric Administration Atlas 14, volume 2, version 3, Ohio River Basin and Surrounding States, accessed April 2, 2014, at http://hdsc.nws.noaa.gov/hdsc/ pfds/pfds_maps.html.

Jobson, H.E., 2001, Predicting river travel time from hydraulic characteristics: Journal of Hydraulic Engineering, v. 127, no. 11, p. 911-918.

Keaton, J.N., Messinger, T., and Doheny, E.J., 2005, Development and analysis of regional curves for streams in the non-urban Valley and Ridge Physiographic Province, Maryland, Virginia, and West Virginia: U.S. Geological Survey Scientific Investigations Report 2005-5076, 116 p.

Kiang, J.E., Stewart, D., Archfield, S.A., Osborne, E.B., and Eng, K., 2013, A National Streamflow Network Gap Analysis: U.S. Geological Survey Scientific Investigations Report 2013-5013, 79 p., 1 appendix as a separate file.

Koenker, Roger, 2013, Quantreg-Quantile Regression: R package version 4.98, accessed April 2, 2014 at http:// CRAN.R-project.org $/$ package $=$ quantreg.

Koltun, G.F., and Kula, S.P., 2013, Methods for estimating selected low-flow statistics and development of annual flow-duration statistics for Ohio: U.S. Geological Survey Scientific Investigations Report 2012-5138, 195 p.

Kozar, M.D., McCoy, K.J., Britton, J.Q., and Blake, B.M. Jr., 2013, Hydrogeology, groundwater flow, and groundwater quality of an abandoned underground coal-mine aquifer, Elkhorn Area, West Virginia: Morgantown, WV, West Virginia Geological and Economic Survey, Bulletin Number B-46.
Krstolic, J.L., 2006, Drainage basins for Virginia and surrounding areas: U.S. Geological Survey Digital Spatial Data Set, accessed April 2, 2014, at http://water.usgs.gov/GIS/ metadata/usgswrd/XML/ofr2006-1308_Drainage_Basin. $x m l$.

Linhart, S.M., Nania, J.F., Sanders, C.L., Jr., and Archfield, S.A., 2012, Computing daily mean streamflow at ungaged locations in Iowa by using the Flow Anywhere and Flow Duration Curve Transfer statistical methods: U.S. Geological Survey Scientific Investigations Report 2012-5232, $50 \mathrm{p}$.

Martin, G.R., and Arihood, L.D., 2010, Methods for estimating selected low-flow frequency statistics for unregulated streams in Kentucky: U.S. Geological Survey Scientific Investigations Report 2010-5217, 83 p.

McKay, L., Bondelid, T., Dewald, T., Rea, A., Johnston, C., and Moore, R., 2013, NHDPlus Version 2: User Guide (Data Model 2.1), accessed April 2, 2014, at http:// www.horizon-systems.com/NHDPlus/NHDPlusV2_ documentation.php.

Messinger, Terence, 2003, Comparison of storm response in streams in small, unmined and valley-filled watersheds, 1999-2001, Ballard Fork, West Virginia: U.S. Geological Survey Water-Resources Investigations Report 02-4303, $22 \mathrm{p}$.

Messinger, Terence, 2009, Regional curves for bankfull channel characteristics in the Appalachian Plateaus, West Virginia: U.S. Geological Survey Scientific Investigations Report 2009-5242, 43 p.

Messinger, Terence, and Hughes, C.A., 2000, Environmental setting and its effects on water quality, Kanawha-New River Basin-West Virginia, Virginia, North Carolina: National Water-Quality Assessment Program: U S. Geological Survey Water-Resources Investigation Report 00-4020, 75 p.

Messinger, Terence, and Paybins, K.S., 2003, Comparison of stream characteristics in small gaged, unmined and valleyfilled watersheds, 1999-2001, Ballard Fork, West Virginia: U.S. Geological Survey Water-Resources Investigations Report 03-4133, 56 p.

National Hydrologic Warning Council, 2006, Benefits of USGS streamgaging program - users and uses of streamflow data, accessed March 19, 2013, online at http://water. usgs.gov/osw/pubs/nhwc_report.pdf.

National Oceanic and Atmospheric Administrations, 2011, 1981-2010 Normals Data Access, accessed April 2, 2014, at http://www.ncdc.noaa.gov/data-access/land-based-stationdata/land-based-datasets/climate-normals/1981-2010normals-data. 
New York Department of Environmental Conservation, 2011, Revised draft SGEIS on the Oil, Gas and Solution Mining Regulatory Program (September 2011) - Well Permit Issuance for Horizontal Drilling and High-Volume Hydraulic Fracturing in the Marcellus Shale and Other Low-Permeability Gas Reservoirs, accessed April 2, 2014, at http://www. dec.ny.gov/energy/75370.html.

Paybins, K.S., 2008, Basin characteristics for selected streamflow-gaging stations in and near West Virginia: U.S. Geological Survey Open-File Report 2008-1087, 9 p., http:// pubs.usgs.gov/of/2008/1087.

Poff, N.L., Richter, B.D., Arthington, A.H., Bunn, S.E., Naiman, R.J., Kendy, E., Acreman, M., Apse, C., Bledsoe, B.P., Freeman, M.C., Henriksen, J., Jacobson, R.B., Kennen, J.G., Merritt, D.M., O'Keeffe, J.H., Olden, J.D., Rogers, K., Tharme, R.E., and Warner, A., 2010, The ecological limits of hydrologic alteration (ELOHA) - a new framework for developing regional environmental flow standards: Freshwater Biology, no. 55, p. 147-170.

PRISM Climate Group, 2012, Precipitation - annual climatology (1981-2010), accessed April 2, 2014, at http://www. prism.oregonstate.edu/normals/.

R Core Team, 2012, R-a language and environment for statistical computing: R Foundation for Statistical Computing, Vienna, Austria, ISBN 3-900051-07-0, accessed April 2, 2014, at http://www.R-project.org/.

Richter, B.D., Davis, M.M., Apse, C., and Konrad, C., 2011, A presumptive standard for environmental flow protection: River Research and Applications 2011, 10 p.

Roland, M.A., and Stuckey, M.H., 2008, Regression equations for estimating flood flows at selected recurrence intervals for ungaged streams in Pennsylvania: U.S. Geological Survey Scientific Investigations Report 2008-5102, 57 p.

Ruhl, K.J., and Martin, G.R., 1991, Low-flow characteristics of Kentucky streams: U.S. Geological Survey WaterResources Investigations Report 91-4097, 50 p.

Runner, G.S., Bragg, R.L., and Atkins, J.T., 1989, Cost effectiveness of the stream-gaging program in West Virginia: U.S. Geological Survey Water-Resources Investigations Report 87-4089, $57 \mathrm{p}$.

Schwietering, J.F., and Bocan, J.M., 2011, Thickness Contours, Polygons (Plate_7, Augmented), Marcellus Shale, West Virginia digital dataset; WV Geologic and Economic Survey Open File Report 8608, accessed April 2, 2014, at http://www.wvgs.wvnet.edu/www/datastat/devshales.htm.
Scott, A.G., 1984, Analysis of characteristics of simulated flows from small surface-mined and undisturbed Appalachian watersheds in the Tug Fork Basin of Kentucky, Virginia, and West Virginia: U.S. Geological Survey WaterResources Investigations Report 84-4151, 169 p., accessed April 2, 2014, at http://pubs.usgs.gov/wri/1984/4151/report. $p d f$.

Soeder, D.J., and Kappel, W.M., 2009, Water resources and natural gas production from the Marcellus Shale: U.S. Geological Survey Fact Sheet 2009-3032, 6 p.

Stedinger, J.R., and Thomas, W.O., Jr., 1985, Low-flow frequency estimation using base-flow measurements: U.S. Geological Survey Open-File Report 85-95, 22 p.

Straub, D.E., 1998, Analysis of the streamflow-gaging station network in Ohio for effectiveness in providing regional streamflow information: U.S. Geological Survey WaterResources Investigations Report 98-4043,

Straub, D.E., 2001, Low-flow characteristics of streams in Ohio through Water Year 1997: U.S. Geological Survey Water-Resources Investigations Report 01-4140, 415 p.

Stuckey, M.H., 2006, Low-flow, base-flow, and mean-flow regression equations for Pennsylvania streams: U.S. Geological Survey Scientific Investigations Report 2006-5130, $84 \mathrm{p}$.

Stuckey, M.H., Koerkle, E.H., and Ulrich, J.E., 2012, Estimation of baseline daily mean streamflows for ungaged locations on Pennsylvania streams, water years 1960-2008: U.S. Geological Survey Scientific Investigations Report 2012-5142, $61 \mathrm{p}$.

U.S. Census Bureau, 2009, West Virginia quick facts, accessed April 2, 2014, at http://quickfacts.census.gov/qfd/ states $/ 54000 . h t m l$.

U.S. Environmental Protection Agency and U.S. Geological Survey, 2012, National Hydrography Dataset PlusNHDPlus version 2, accessed April 2, 2104, at http://www. horizon-systems.com/NHDPlus/NHDPlusV2_home.php.

U.S. Geological Survey, 2005a, Hydrologic units (watersheds), two-million scale, accessed April 2, 2014, at http:// nationalatlas.gov/atlasftp.html.

U.S. Geological Survey, 2005b, Streams and waterbodies, two-million scale, accessed April 2, 2104, at http:// nationalatlas.gov/atlasftp.html.

U.S. Geological Survey, 2005c, State boundaries, two-million scale, accessed April 2, 2014, at http://nationalatlas.gov/ atlasftp.html.

U.S. Geological Survey, 2007, National Elevation Dataset 1 arc-second, accessed April 2, 2014, at http:/viewer. nationalmap.gov/viewer/. 
U.S. Geological Survey, 2013a, Annual Water Data Reports, accessed April 2, 2014, at http://wdr.water.usgs.gov/.

U.S. Geological Survey, 2013b, National Water Information System: Web Interface, Current Water Data for the Nation, accessed April 2, 2014, at http://waterdata.usgs.gov/usa/ nwis/rt.

U.S. Geological Survey, 2013c, StreamStats state applications, accessed April 2, 2014, at http://streamstats.usgs.gov/ ssonline.html.

U.S. Geological Survey National Assessment of Oil and Gas Resources Team, and Biewick, L.R.H., compiler, 2013, Map of assessed shale gas in the United States, 2012: U.S. Geological Survey Digital Data Series 69-Z, 16 p., 1 pl., GIS data package, accessed April 2, 2014, at http://pubs.usgs. gov/dds/dds-069/dds-069-z/.

Wahl, K.L., Thomas, W.O., Jr., and Hirsch, R.M., 1995, The stream-gaging program of the U.S. Geological Survey: U.S. Geological Survey Circular 1123, 22 p.

Ward, S.M., Topalanchik, A.R., Milliman, G.R., and Wigal, R.A., 1991, Sediment loads in an undisturbed basin and a basin disturbed by gas-well drilling, Ritchie County, West Virginia, 1985-1987: U.S. Geological Survey WaterResources Investigations Report 90-4100, 28 p, accessed April 2, 2014, at http://pubs.usgs.gov/wri/1990/4100/report. $p d f$.

West Virginia Department of Environmental Protection, 2013a, Office of Oil and Gas, accessed April 2, 2014, at http://www.dep.wv.gov/oil-and-gas/Pages/default.aspx.

West Virginia Department of Environmental Protection, 2013b, Resource extraction data viewer, accessed April 2, 2014, at http://tagis.dep.wv.gov/fogm/.

West Virginia Department of Environmental Protection, 2013, Water Withdrawal Guidance Tool, accessed April 2, 2014, at http://www.dep.wv.gov/WWE/wateruse/Pages/ WaterWithdrawal.aspx.

Wiley, J.B., Atkins, J.T., Jr., and Newell, D.A., 2002, Estimating the magnitude of annual peak discharges with recurrence intervals between 1.1 and 3.0 years for rural, unregulated streams in West Virginia: U.S. Geological Survey Water-Resources Investigations Report 02-4164, 73 p.

Wiley, J.B., 2006, Low-flow analysis and selected flow statistics representative of the period 1930-2002 for streamflowgaging stations in or near West Virginia: U.S. Geological Survey Scientific Investigations Report 2006-5002, 190 p.

Wiley, J.B., 2008, Estimating selected streamflow statistics representative of 1930-2002 in West Virginia: U.S. Geological Survey Scientific Investigations Report 2008-5105, $24 \mathrm{p}$.
Wiley, J.B., and Atkins, J.T., Jr., 2010a, Estimation of floodfrequency discharges for rural, unregulated streams in West Virginia: U.S. Geological Survey Scientific Investigations Report 2010-5033, 78 p.

Wiley, J.B., and Atkins, J.T., Jr., 2010b, Estimation of selected seasonal streamflow statistics representative of 1930-2002 in West Virginia: U.S. Geological Survey Scientific Investigations Report 2010-5185, 20 p. 


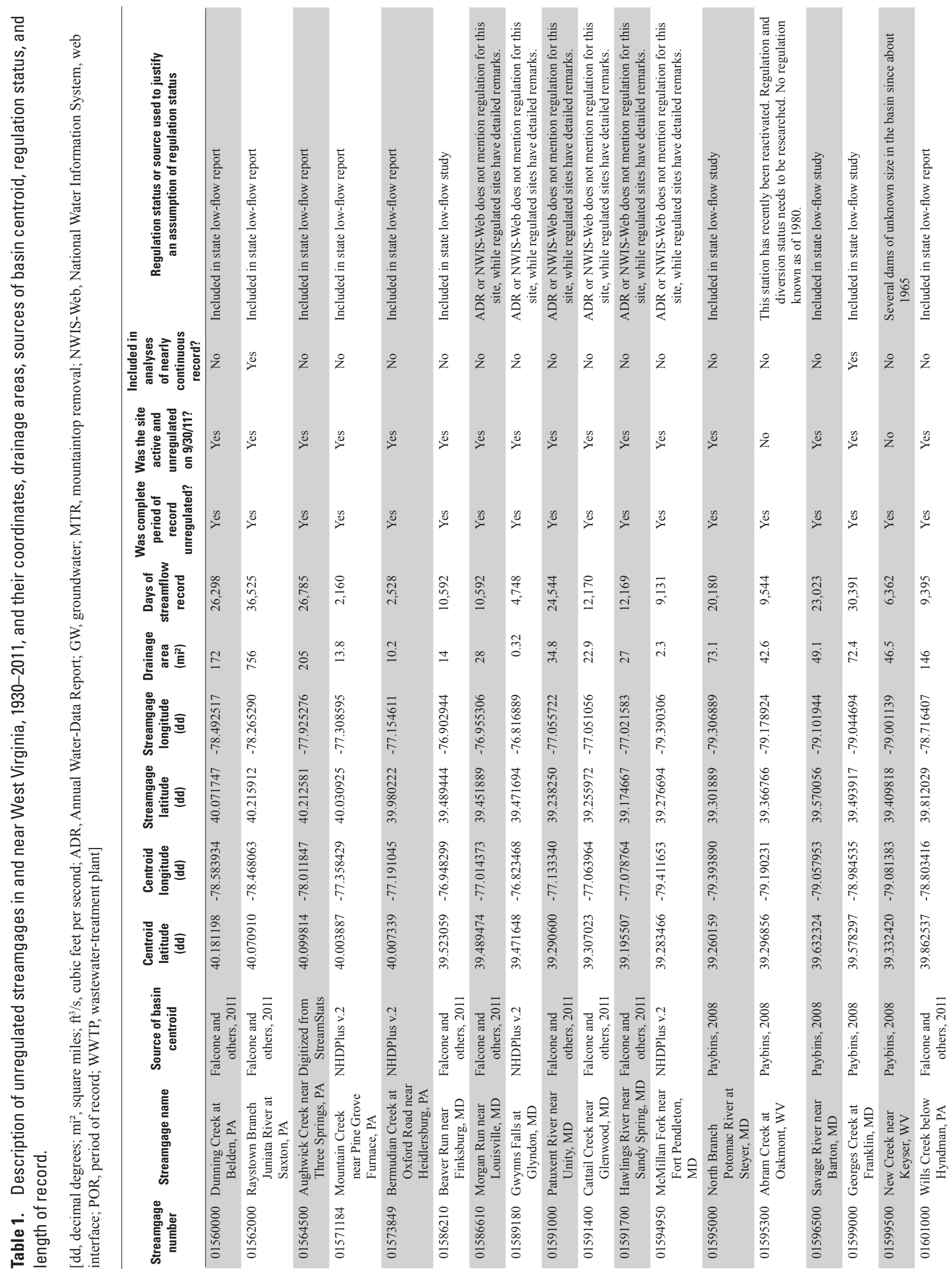




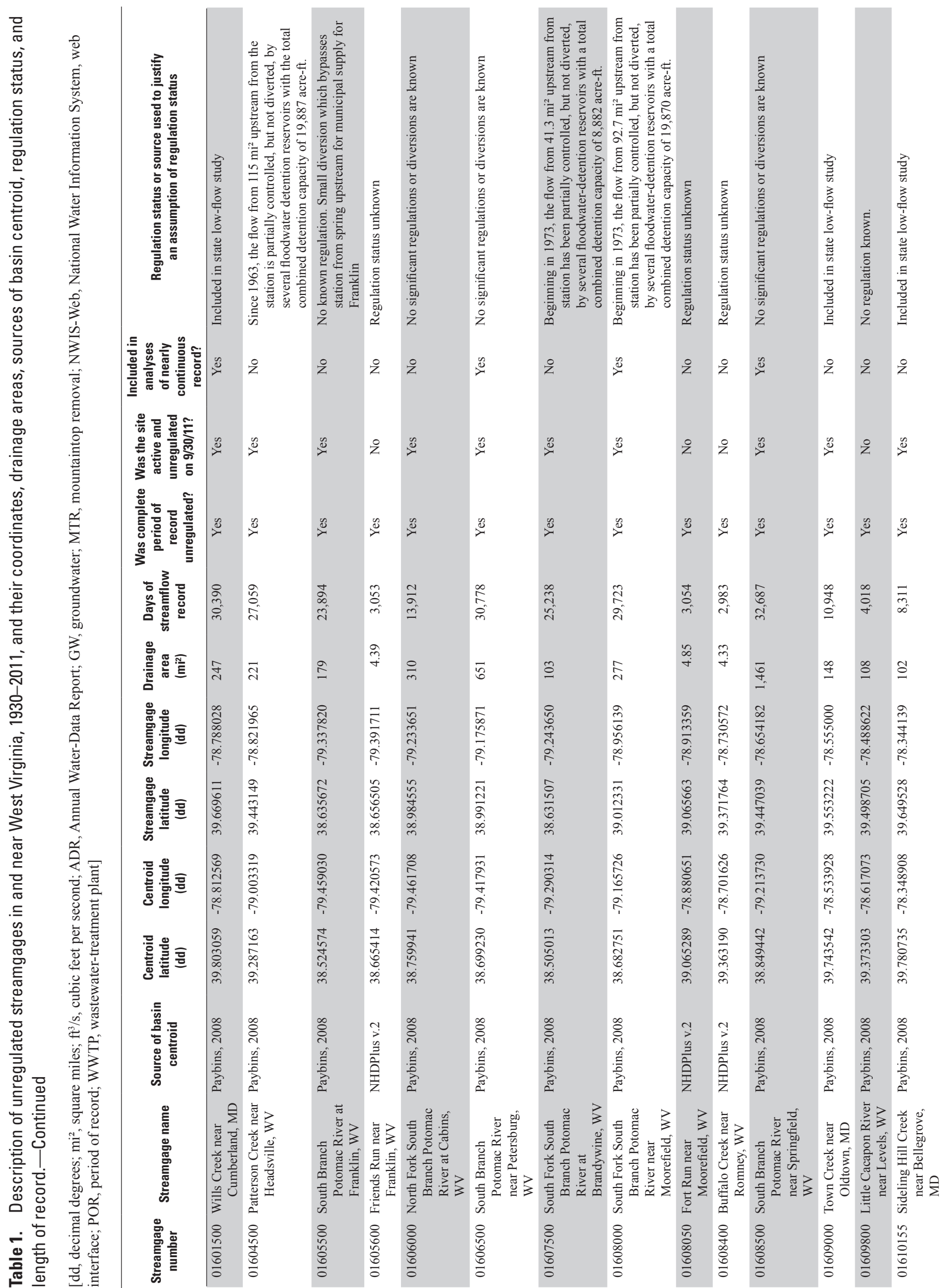


Tables $\quad 47$

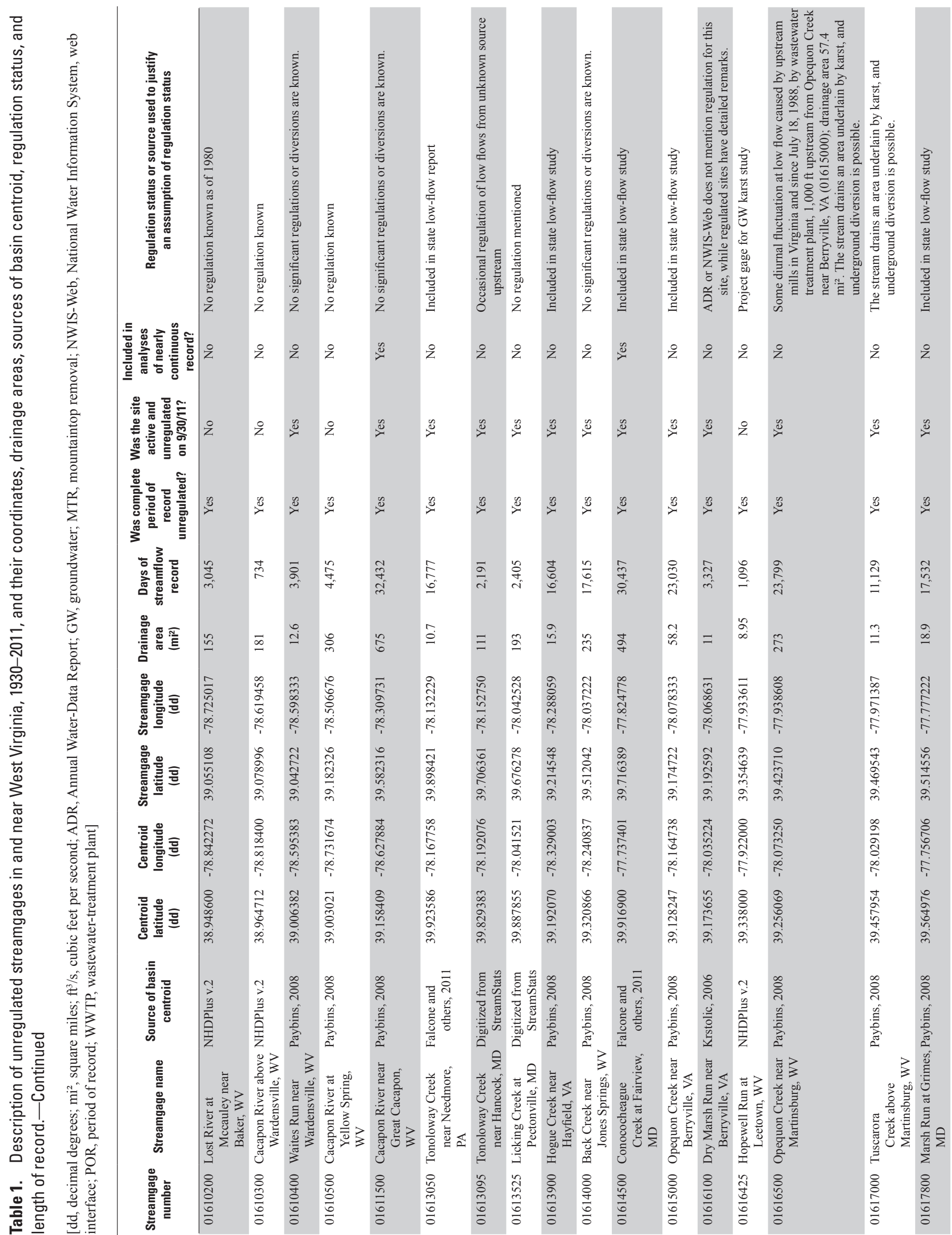




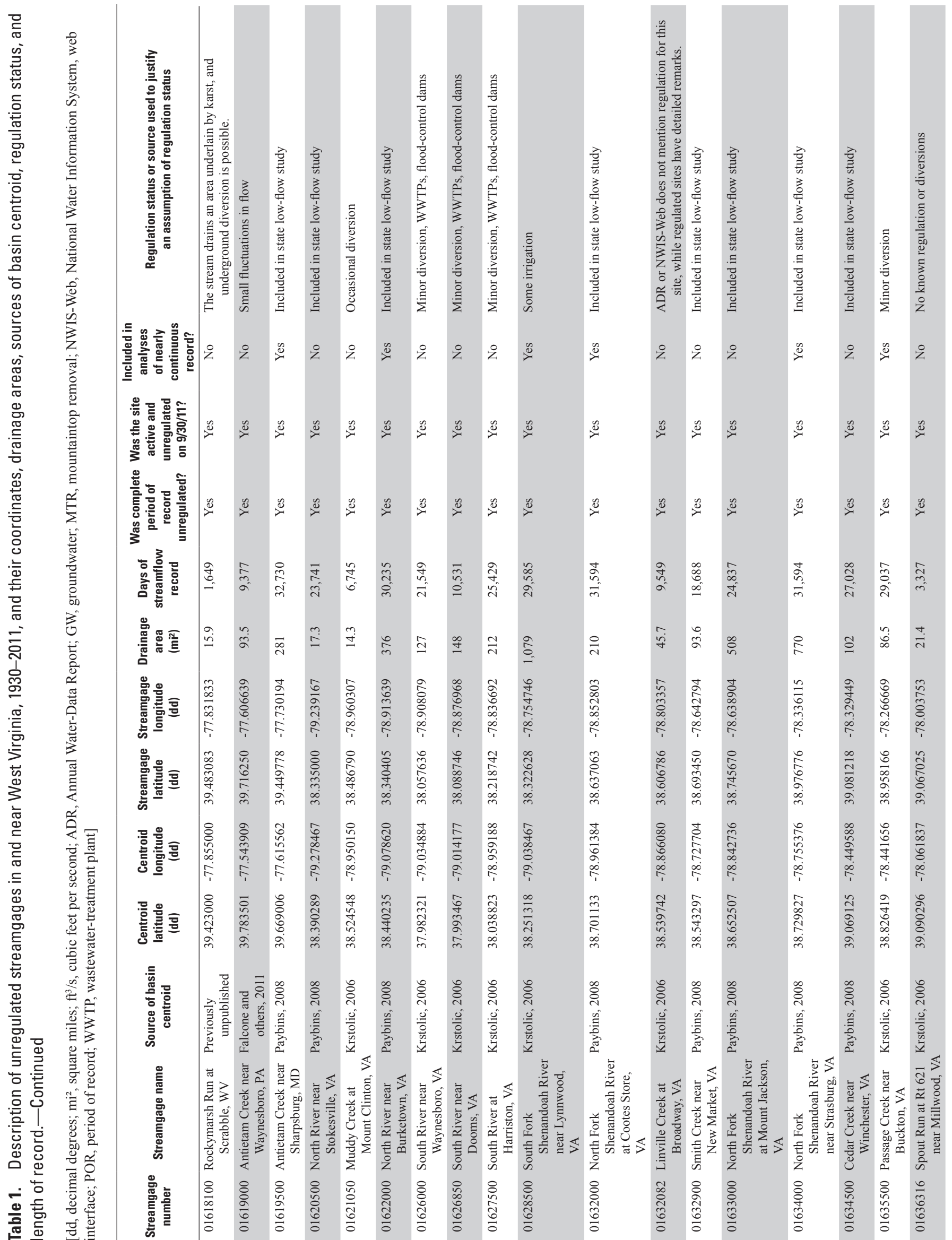




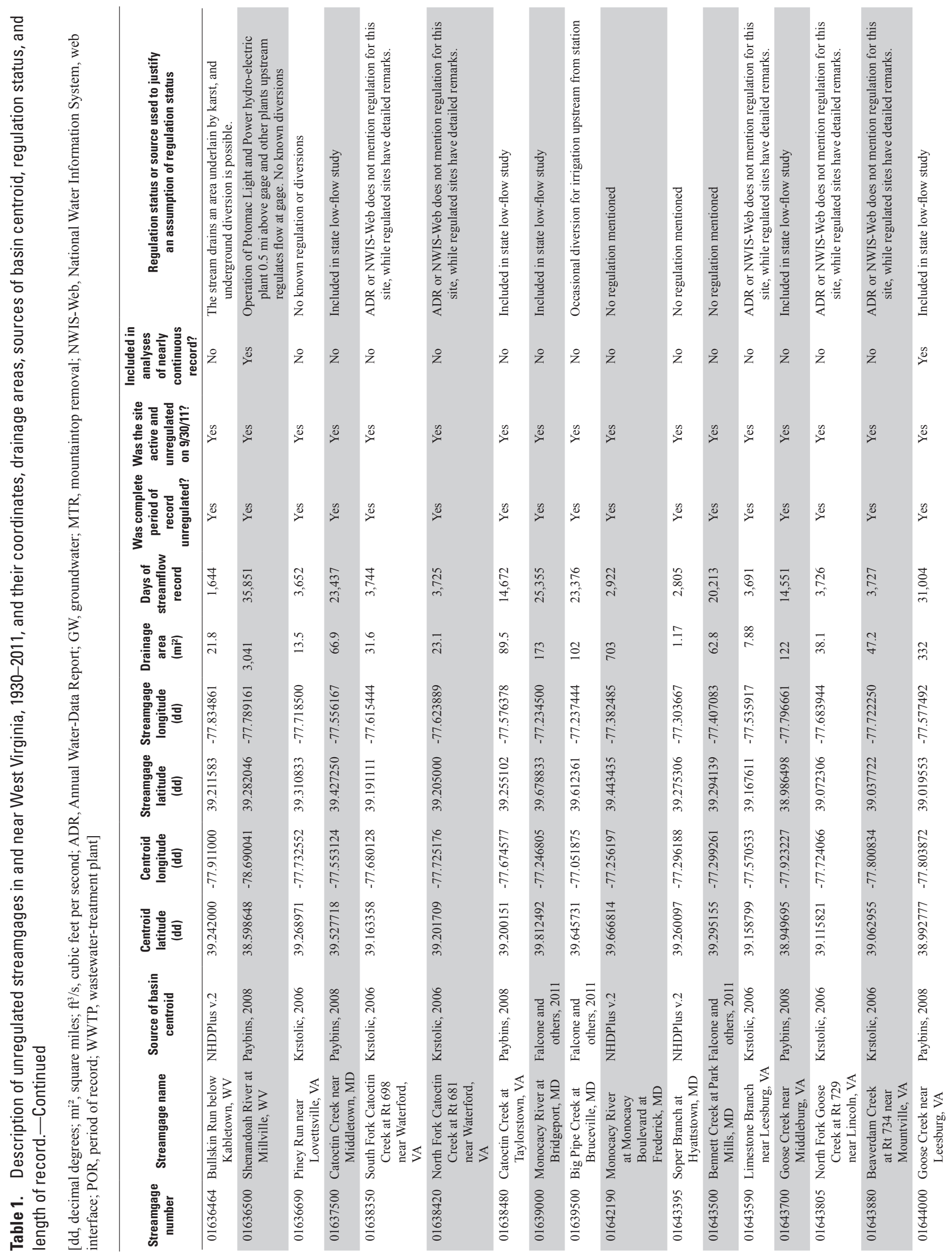




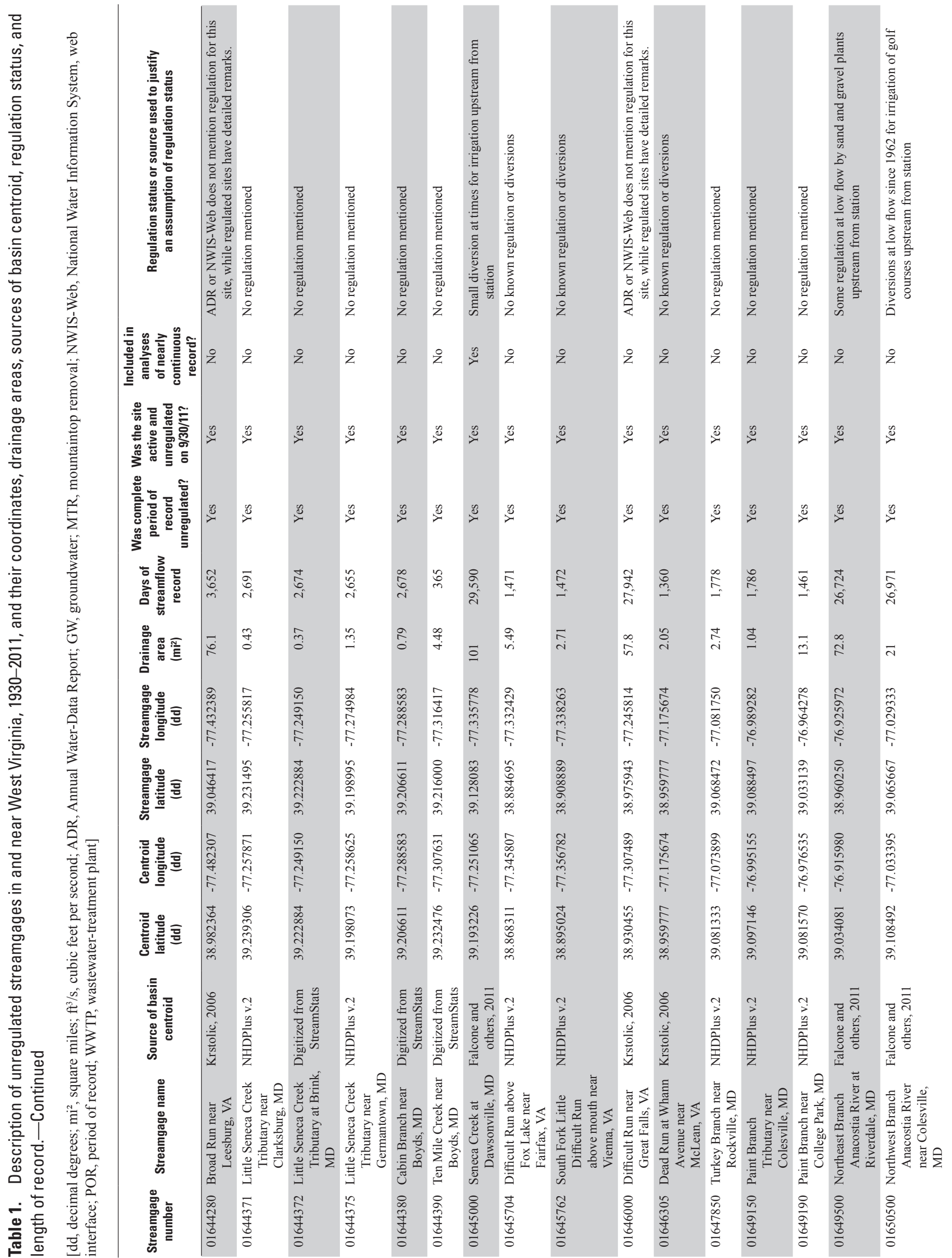


Tables

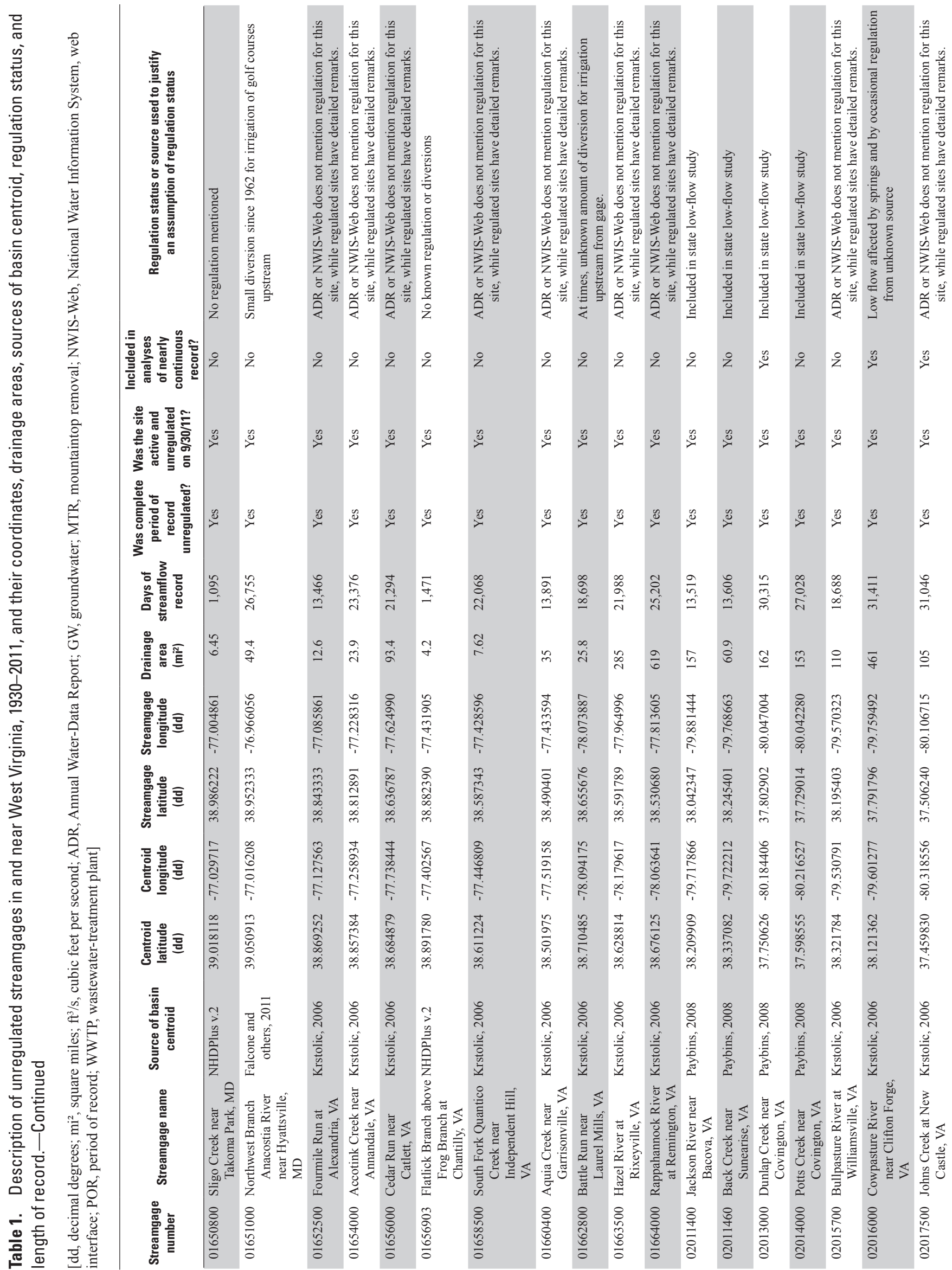




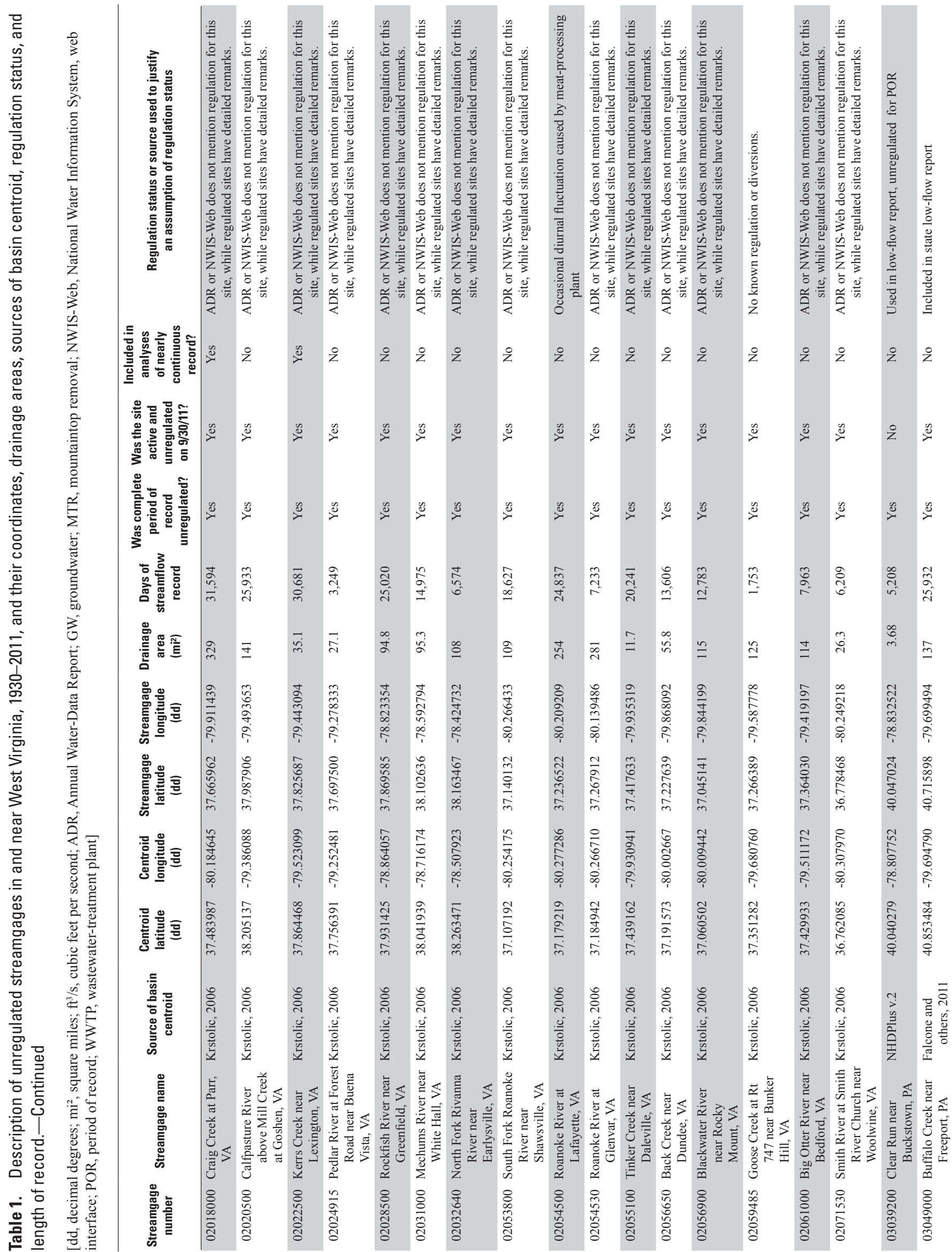




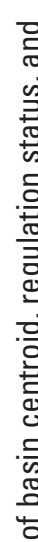

흠

言

$$
\text { (2) }
$$$$
\text { (1) }
$$

.
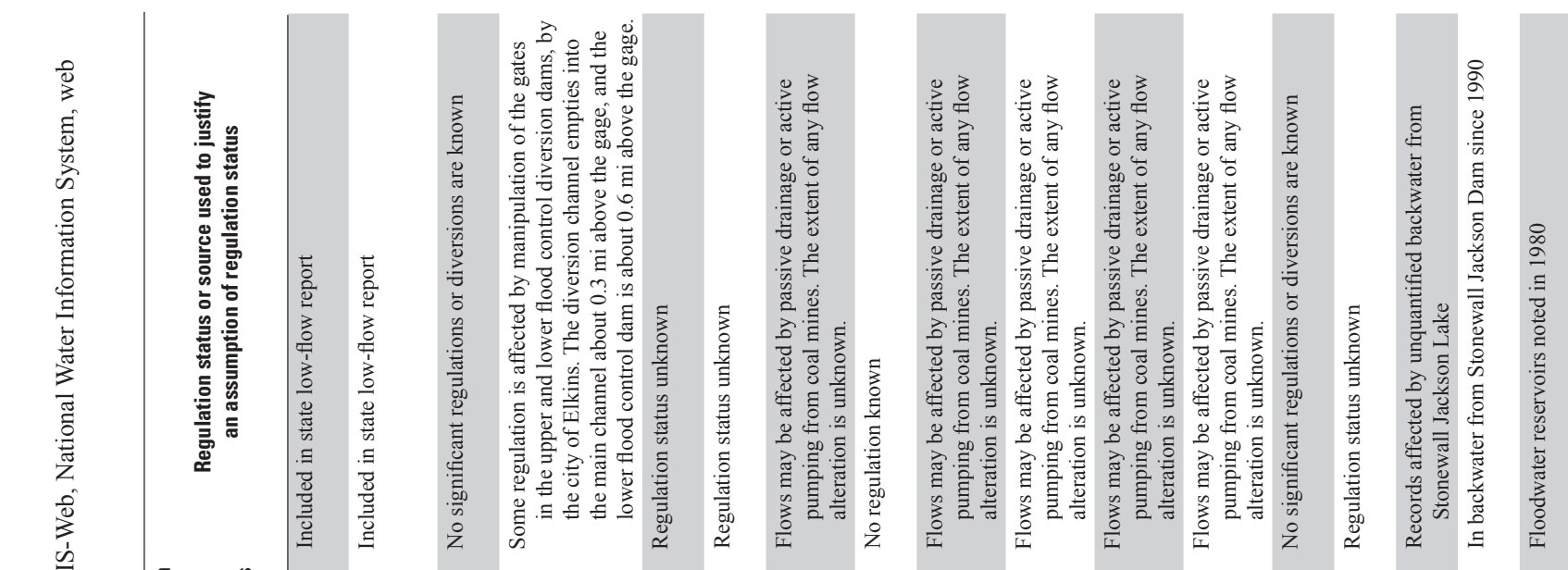

IIIn:
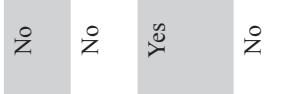

$\gtrless$

ż ஜ

$\stackrel{\infty}{2}$

$\stackrel{0}{\circ}$

$\mathscr{0}$

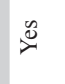

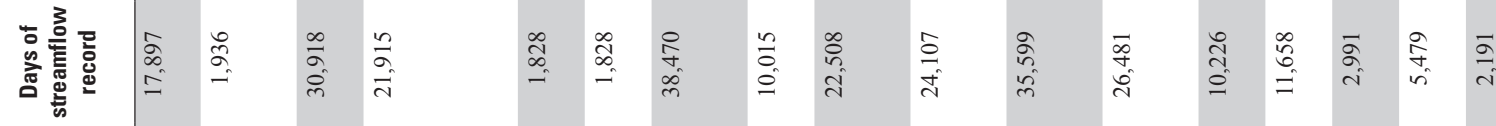

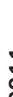

ลั.

空

举

要 苟

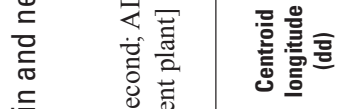

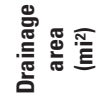

$\underset{\infty}{\infty} \stackrel{2}{\infty}$

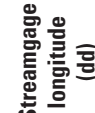

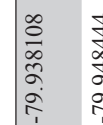

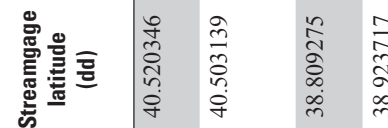

รั)

京

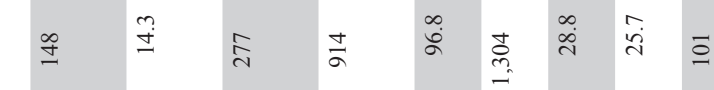

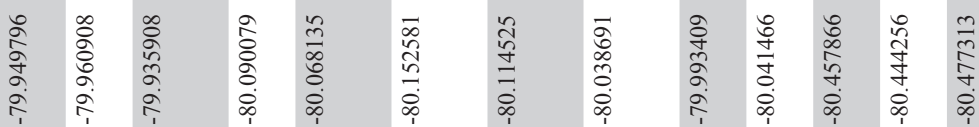

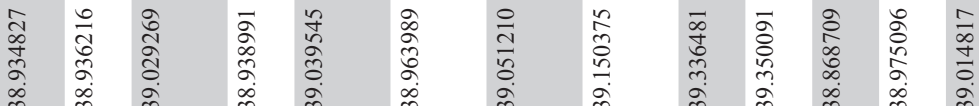

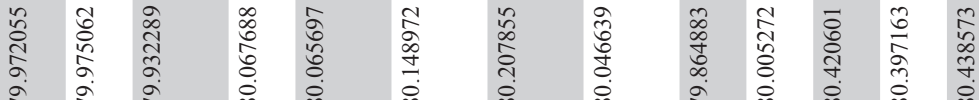

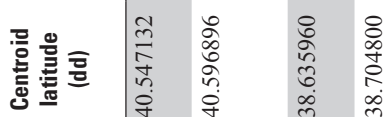

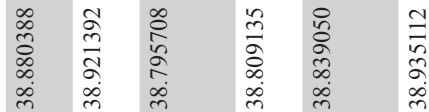

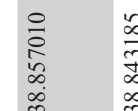

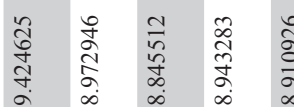

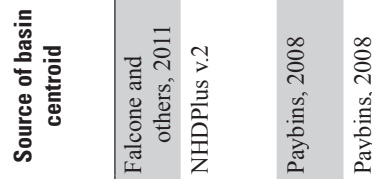

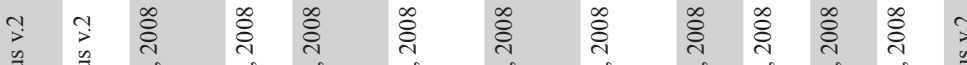

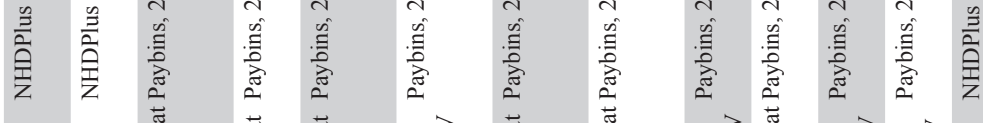

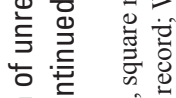

등 管

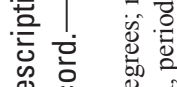

造哭

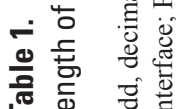

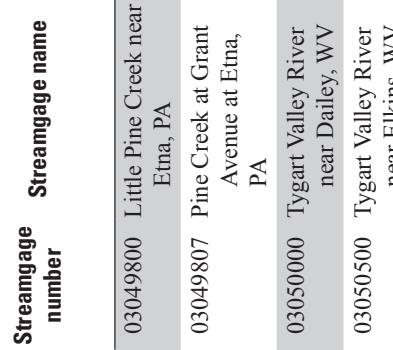

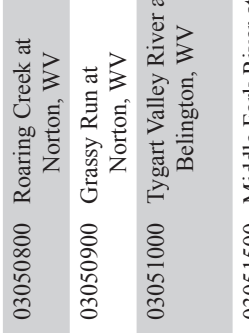

(⿻)

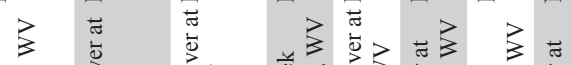

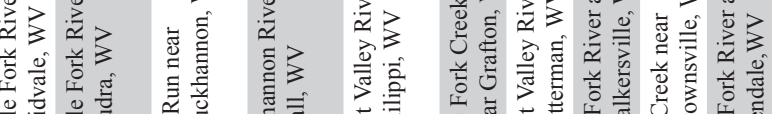

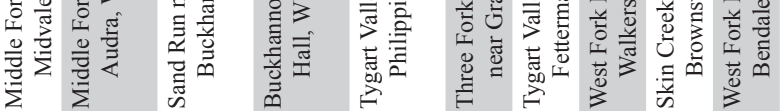




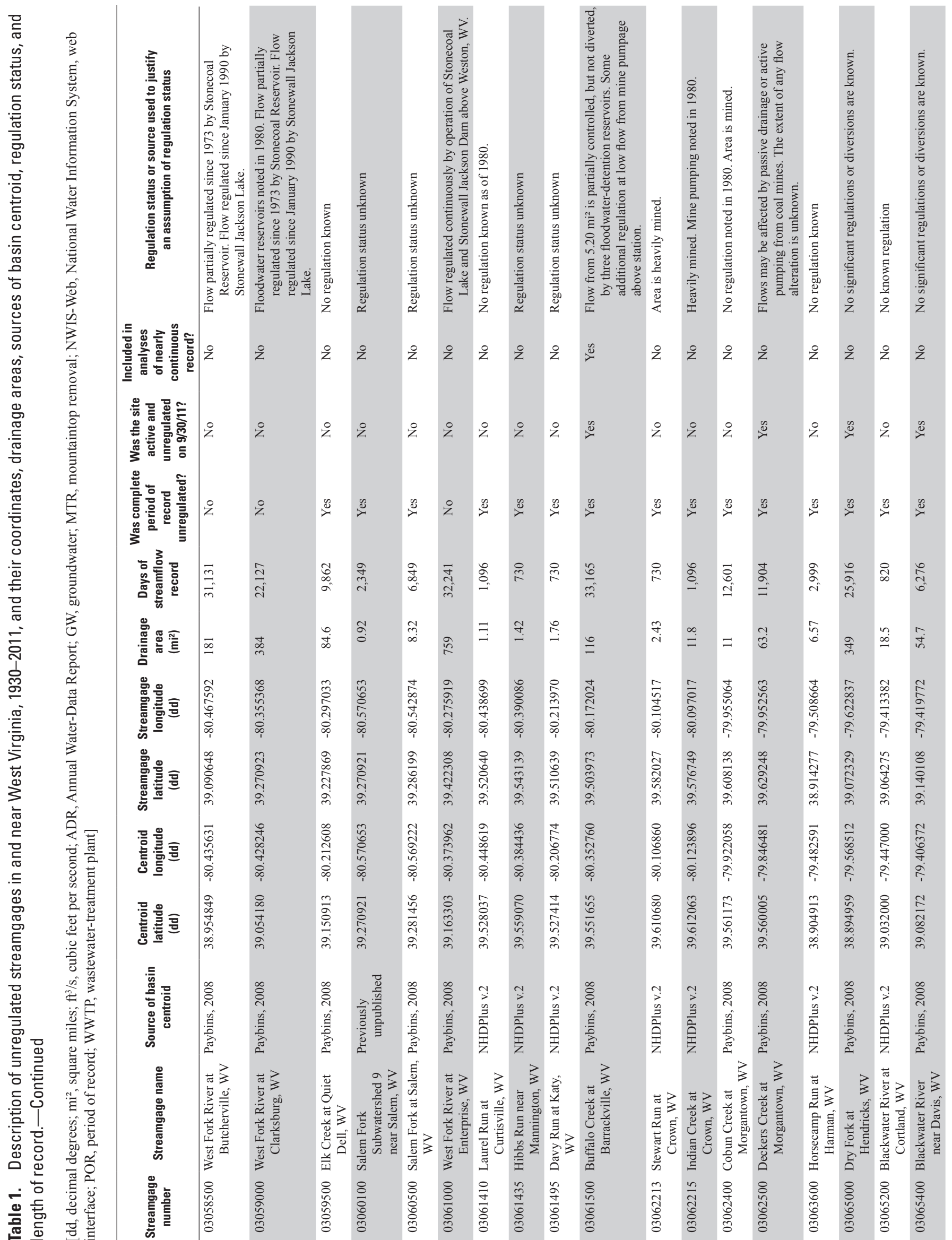




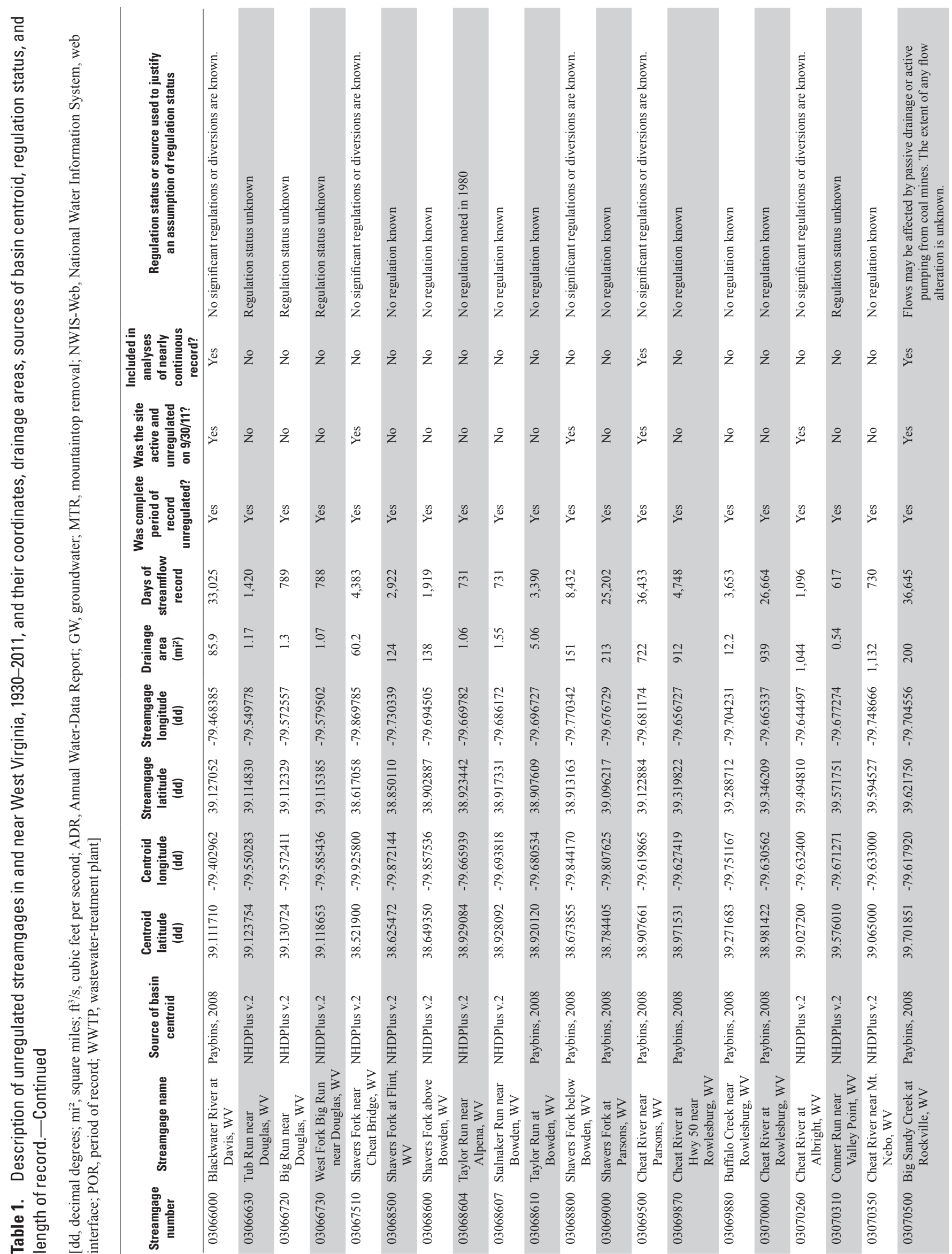




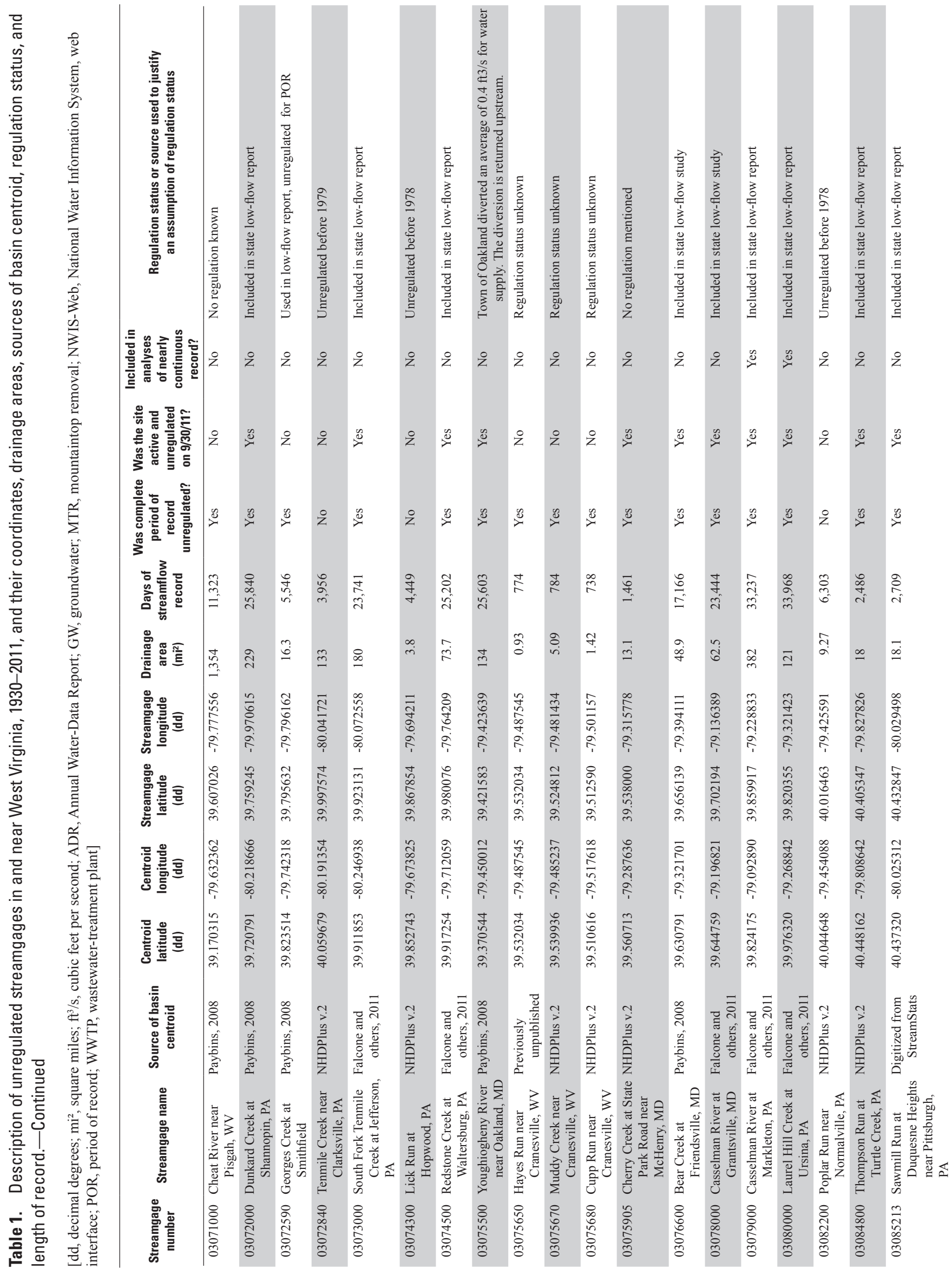




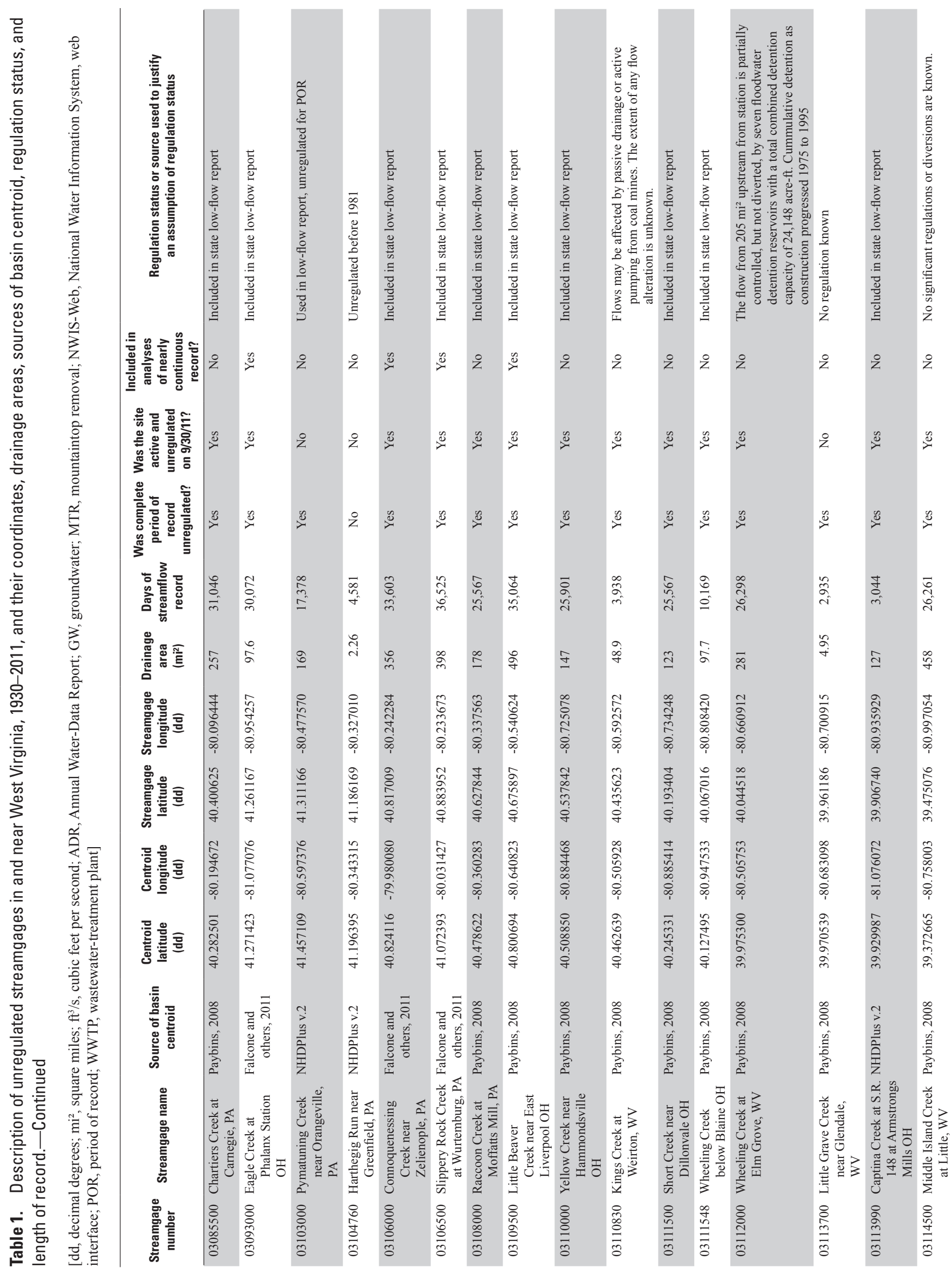




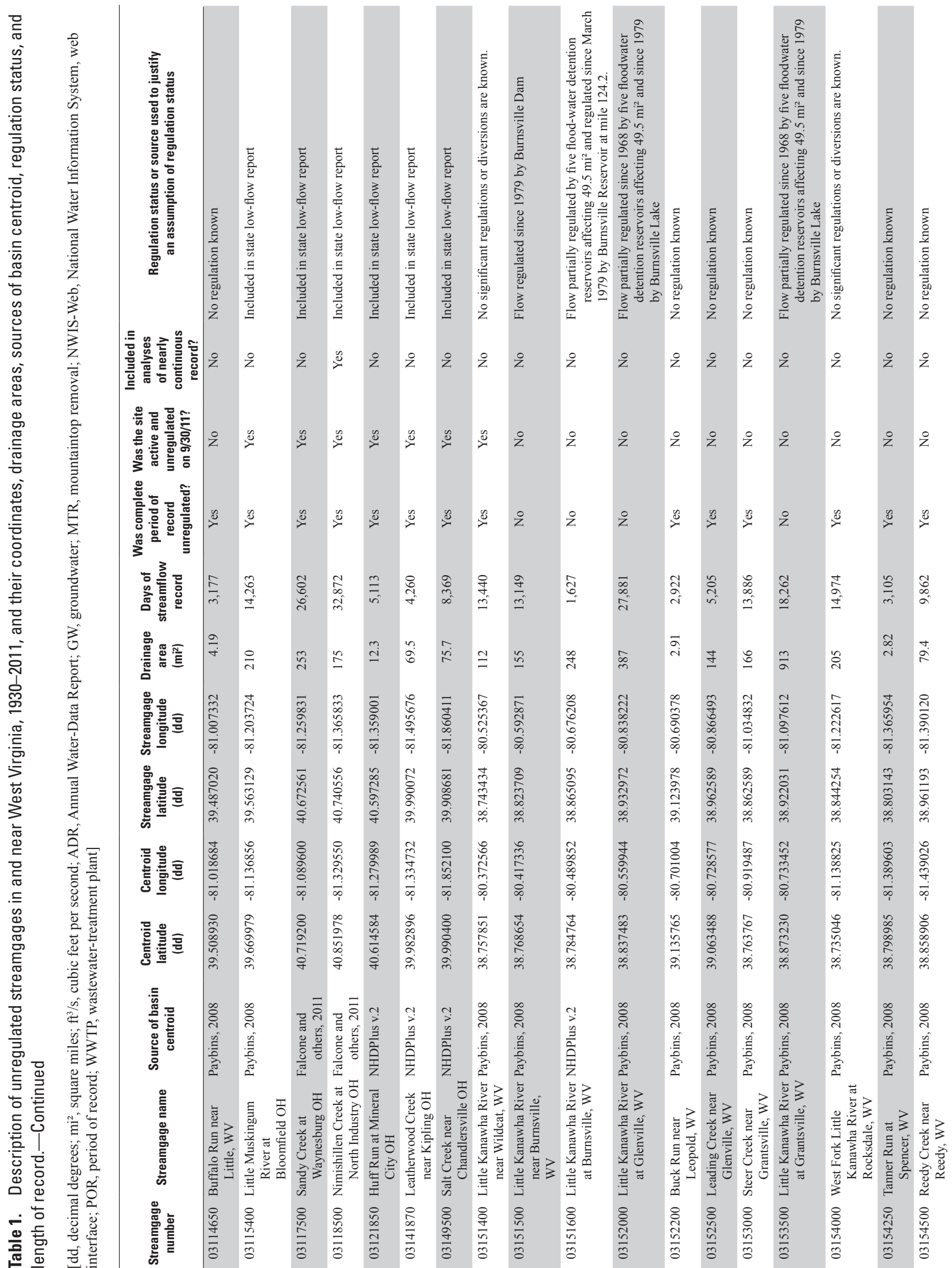




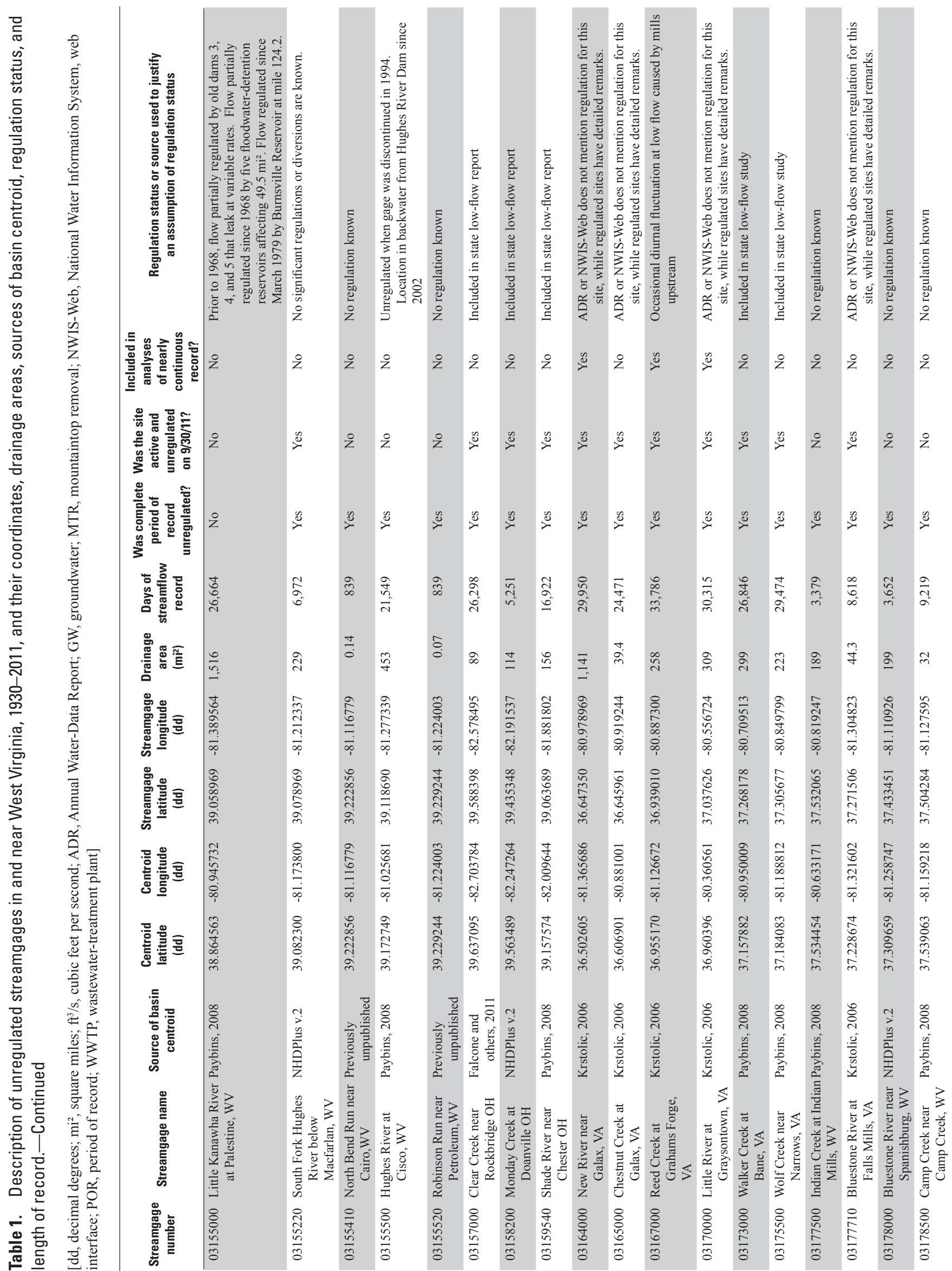




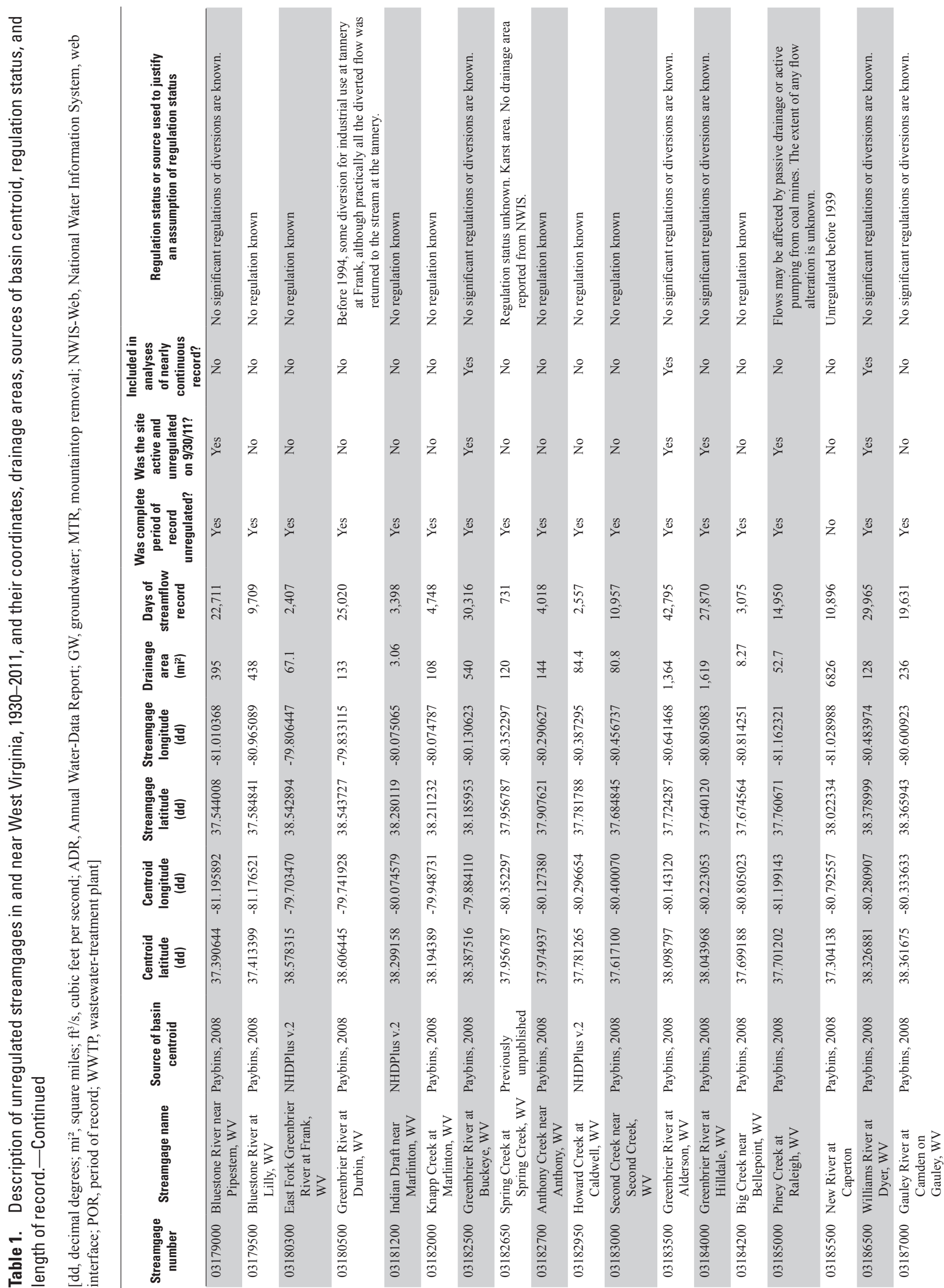




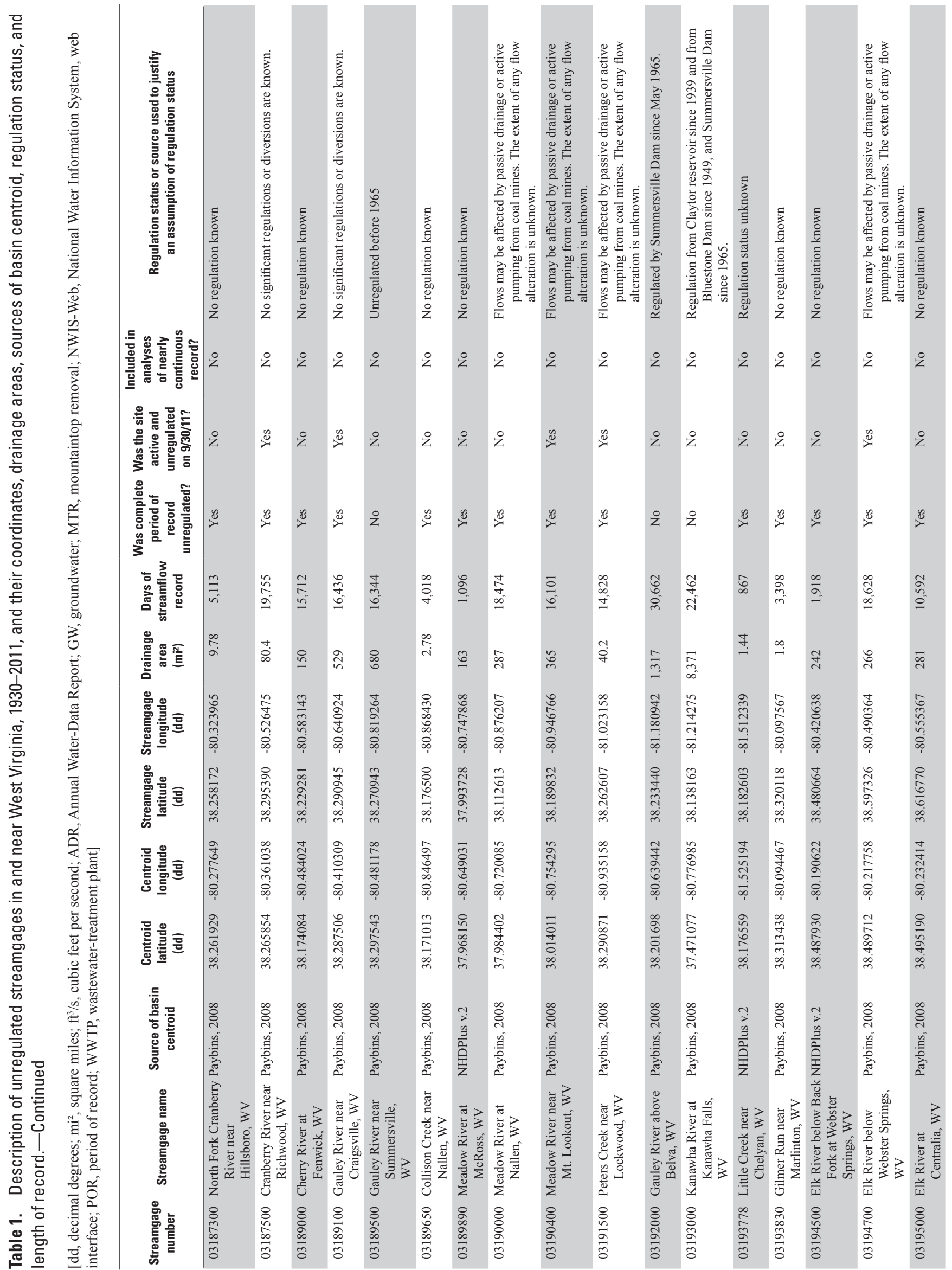




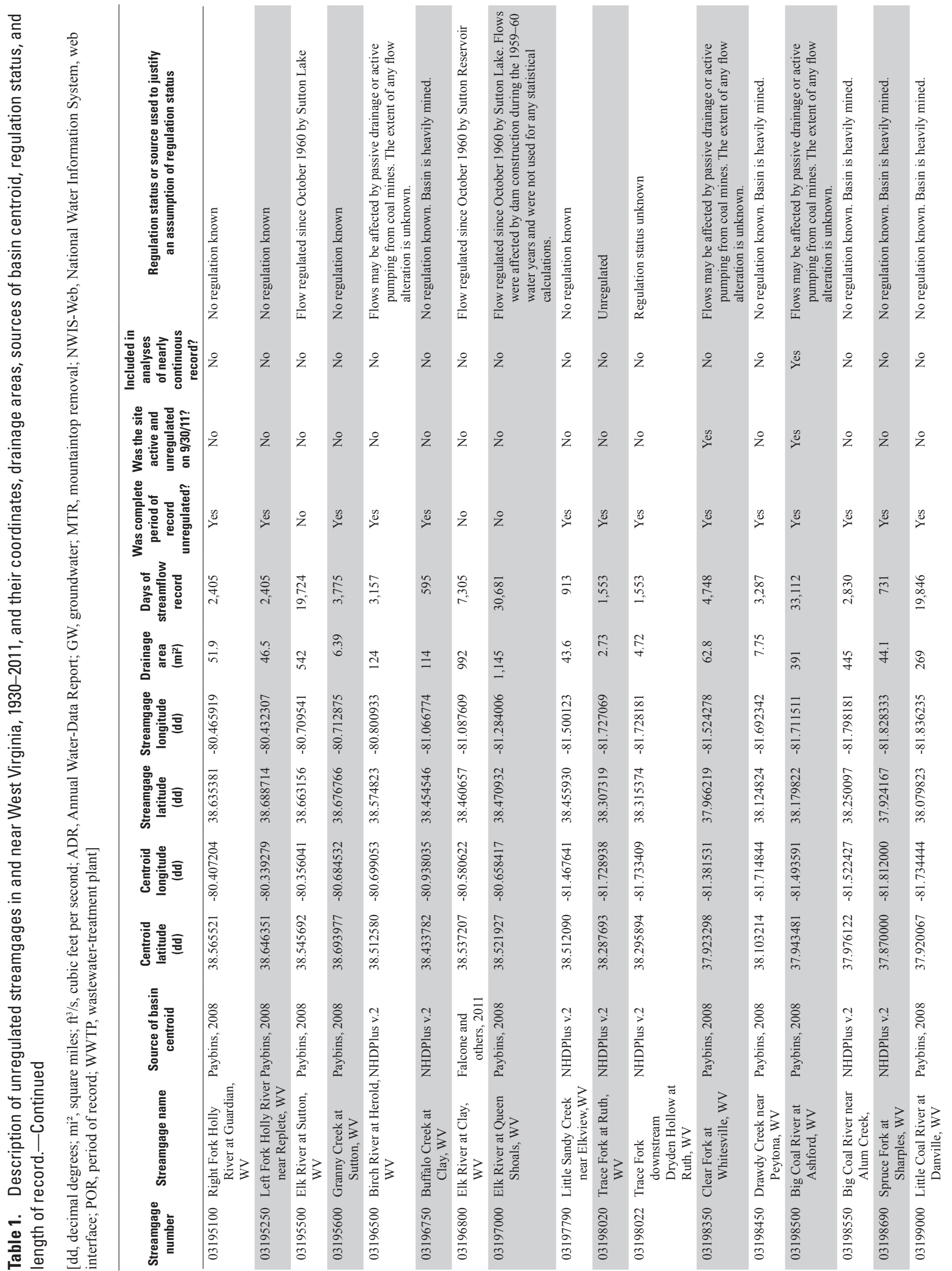




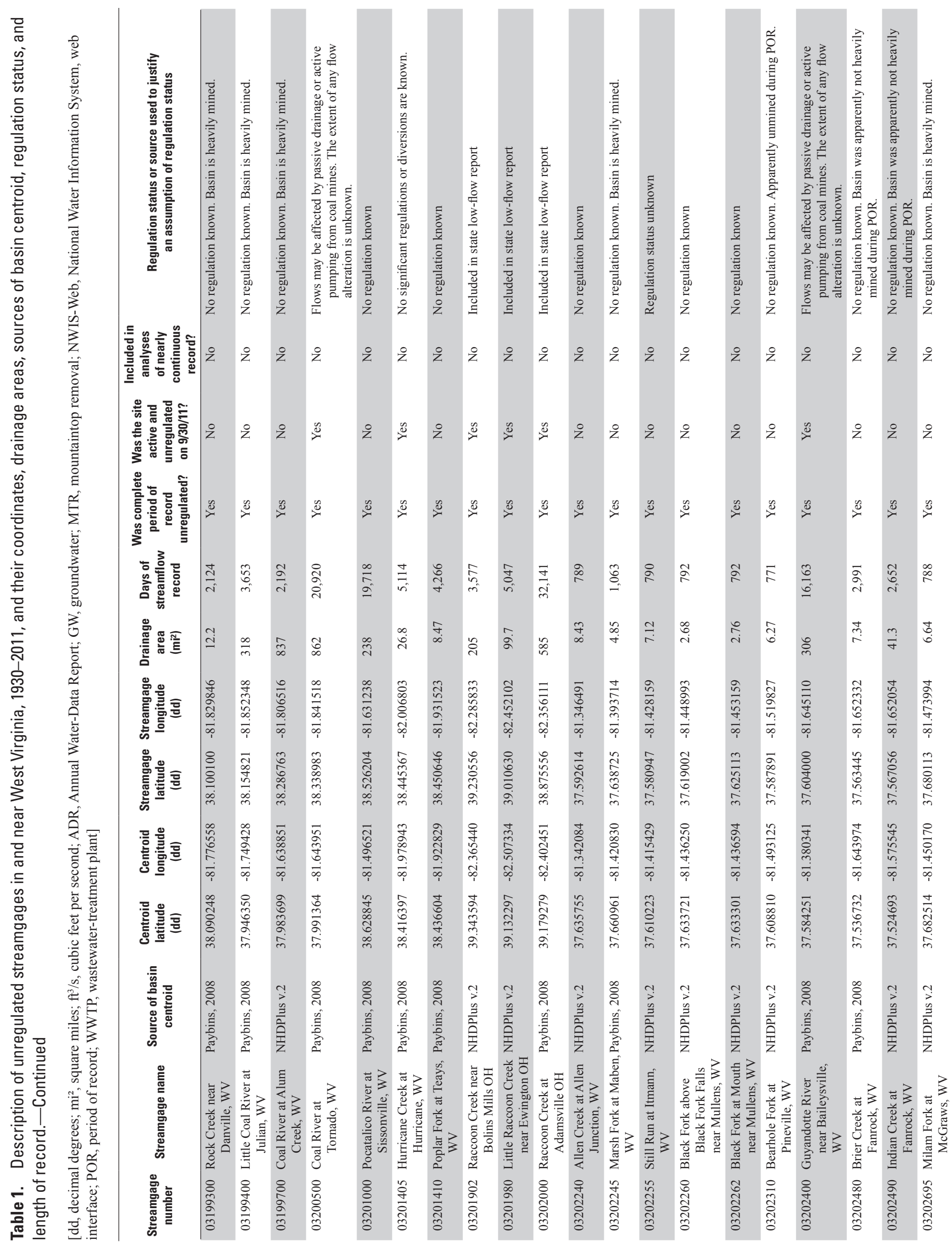



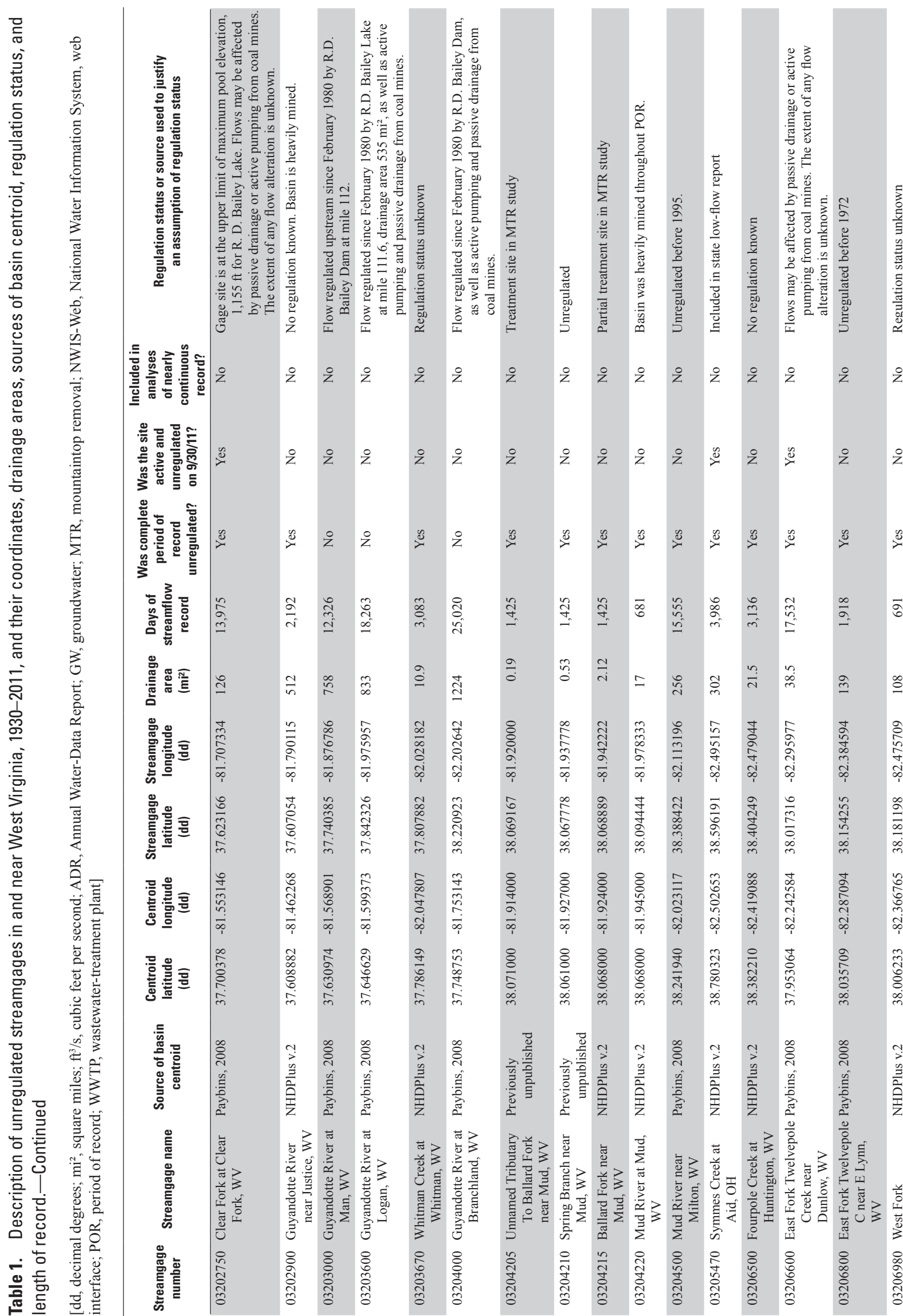

IIIn:
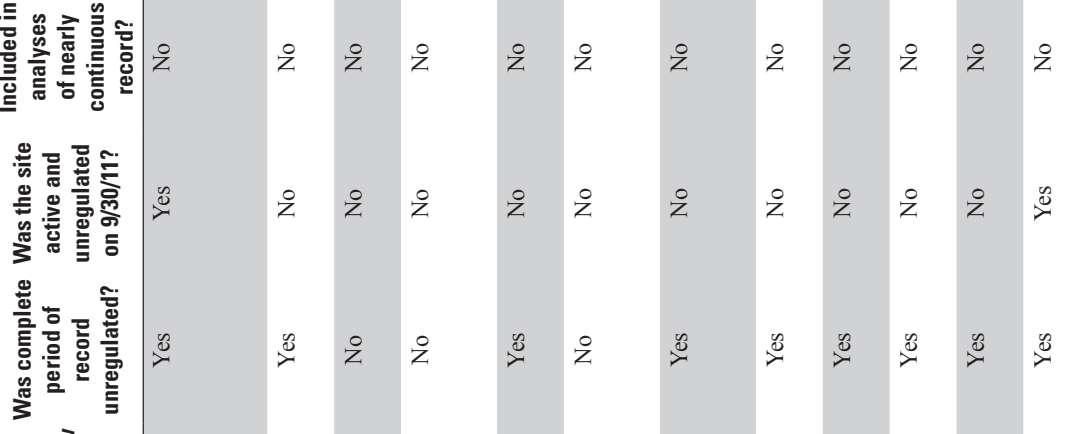

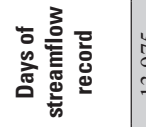
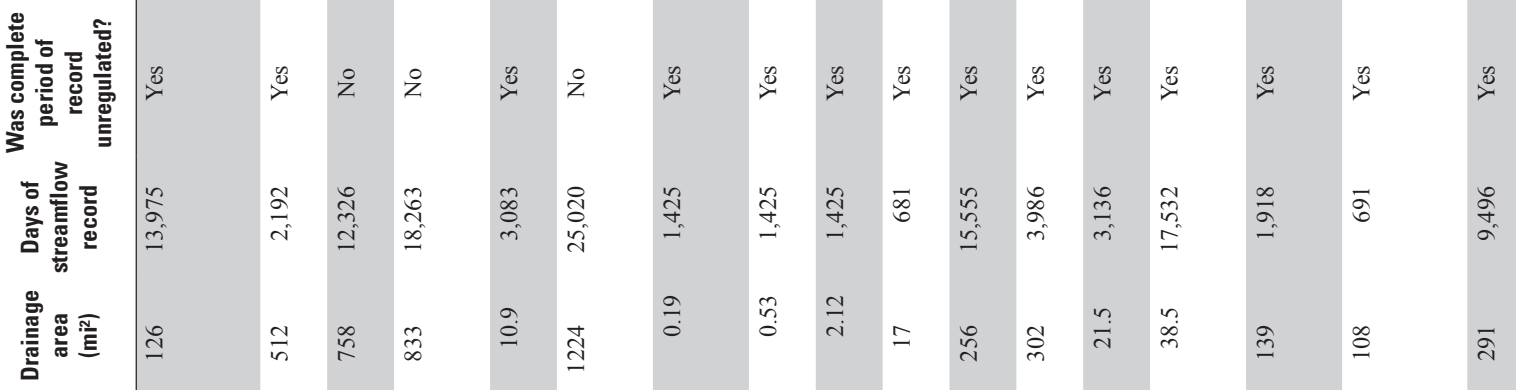

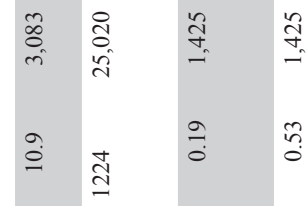

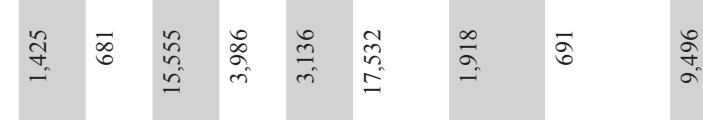

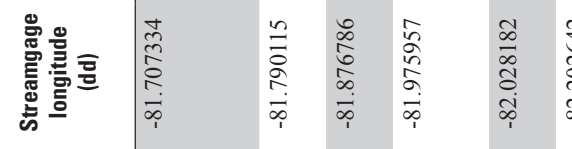

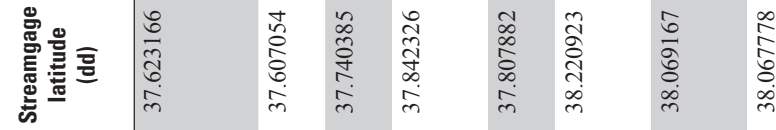

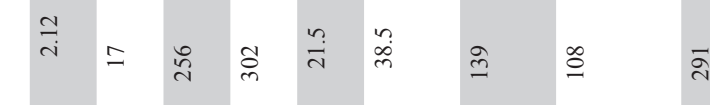

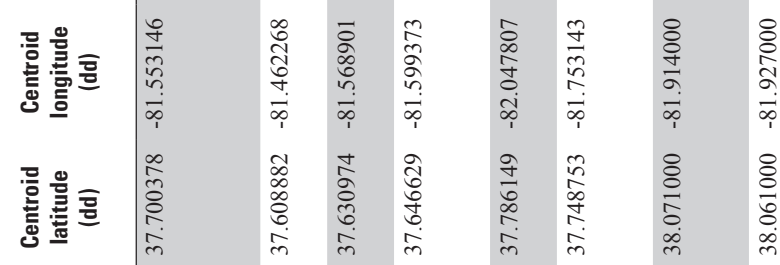

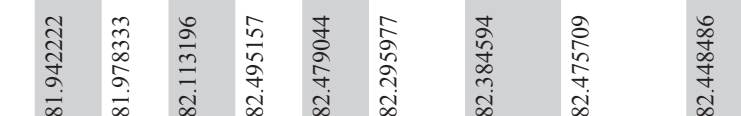

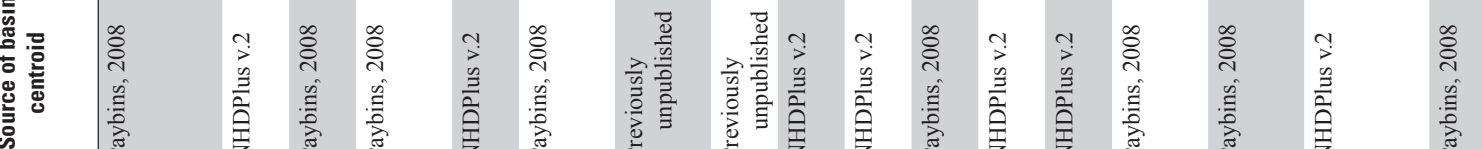

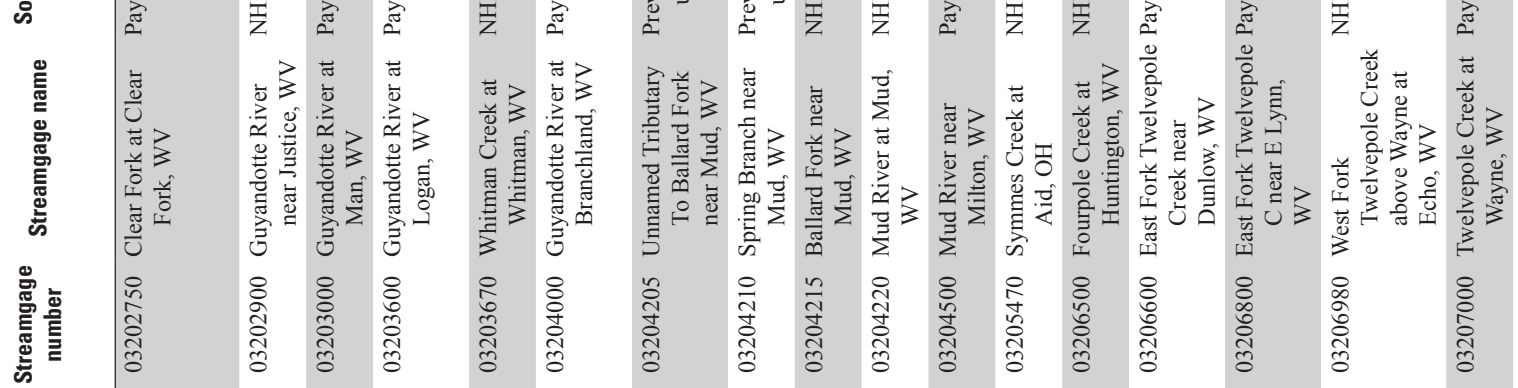




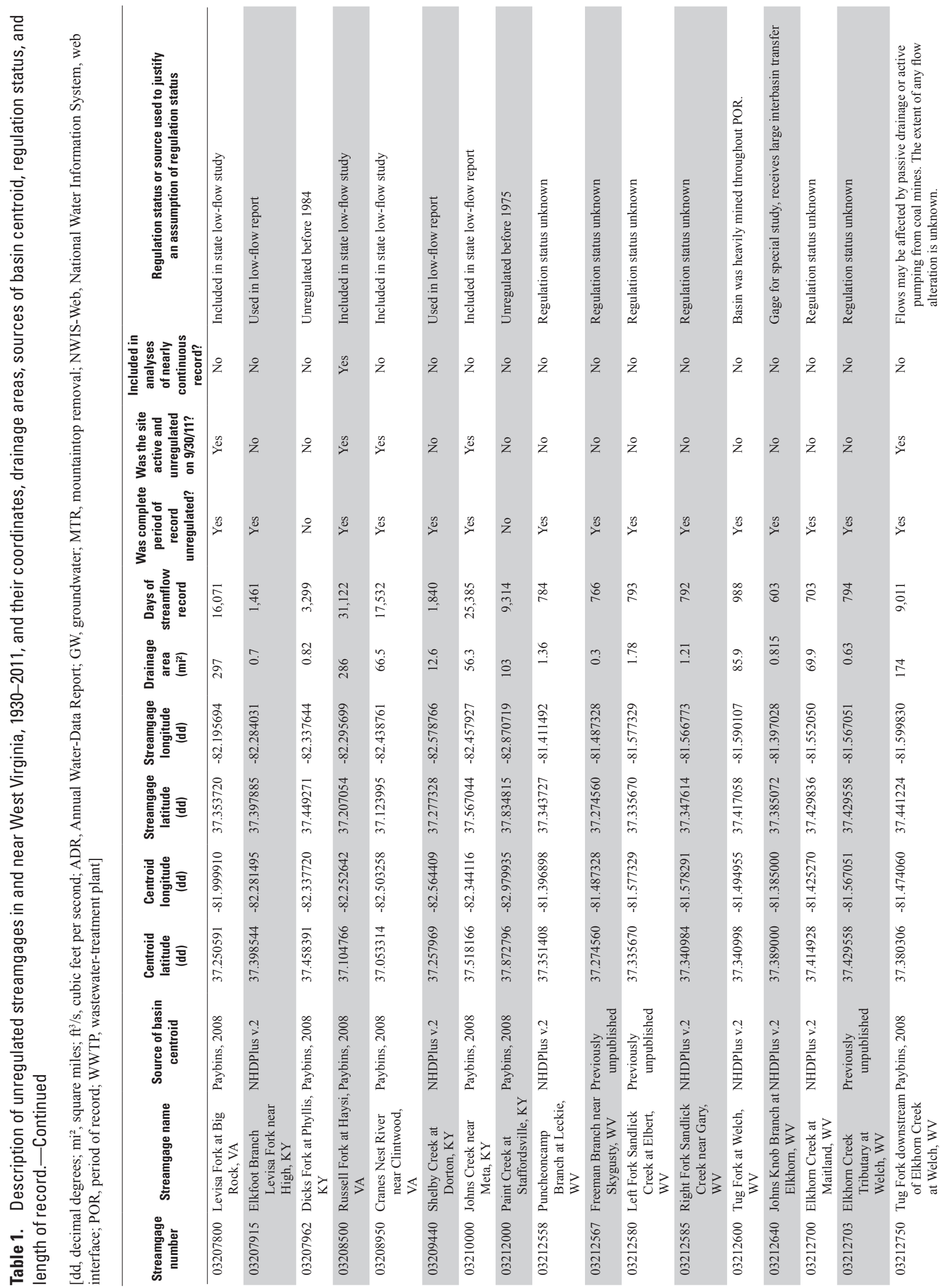




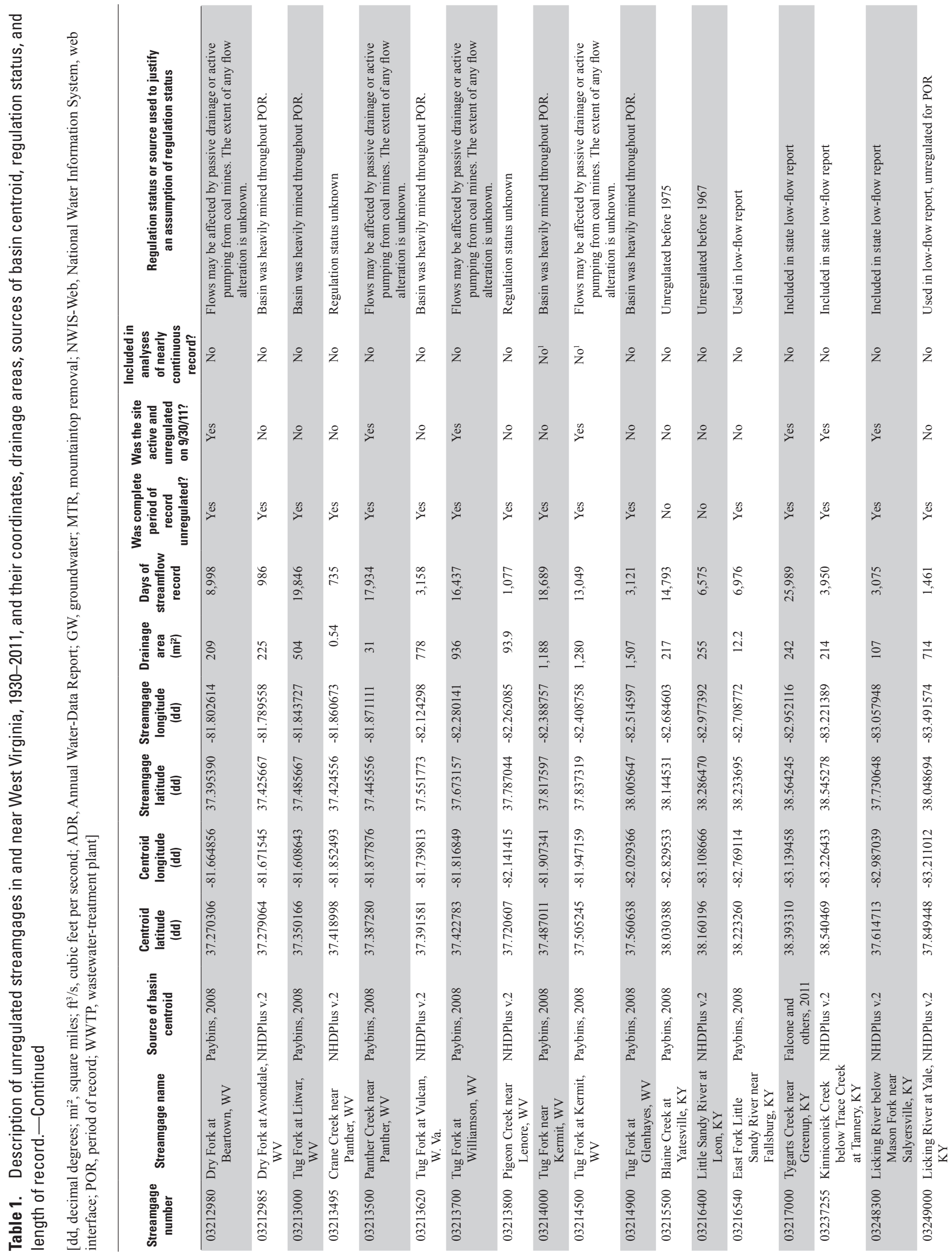




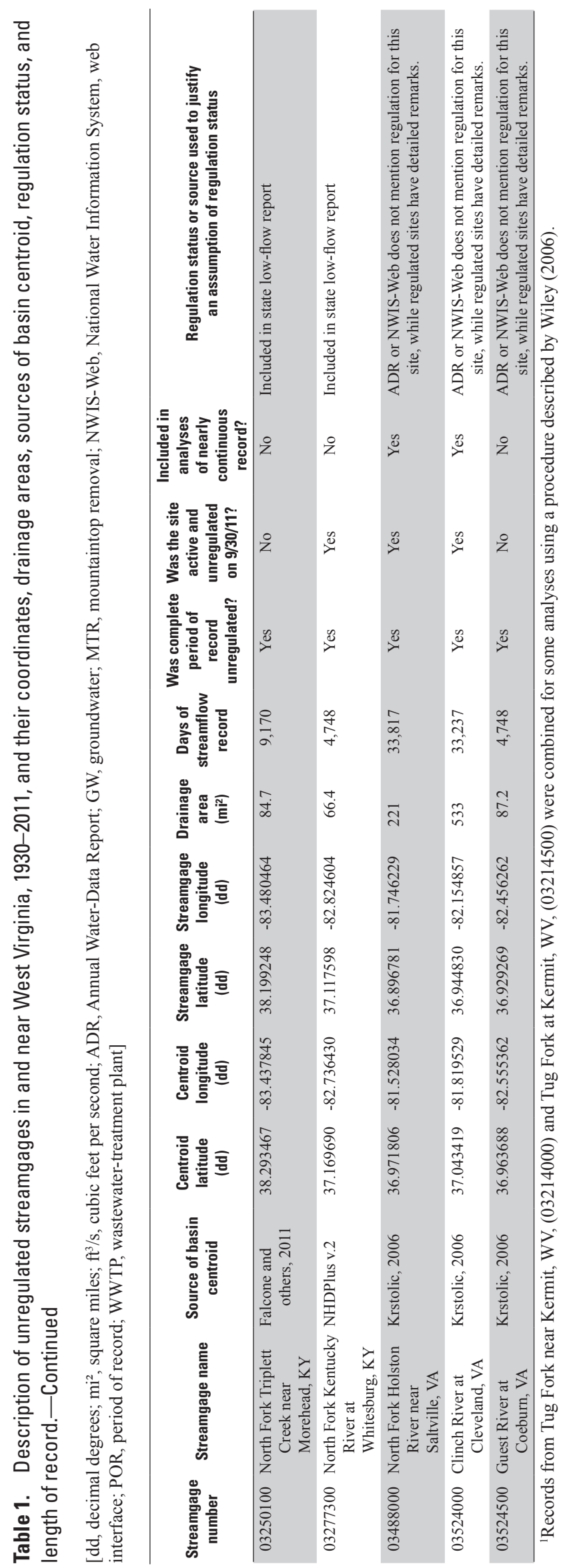


Table 5. Number of days exceeding the annual 75-percent flow duration for 15 selected streamgages in West Virginia, 1930-2011, and their average as a proportion.

[Average is for full years only. NO, not operated during that water year; PR, operated for part of the year. Flow duration values from Wiley, 2006]

\begin{tabular}{|c|c|c|c|c|c|c|c|c|c|c|c|c|c|c|c|c|}
\hline \multirow{2}{*}{ Water year } & \multicolumn{15}{|c|}{ Streamgage } & \multirow{2}{*}{ Average } \\
\hline & 01606500 & 01608500 & 01611500 & 01636500 & 03051000 & 03053500 & 03061500 & 03066000 & 03069500 & 03070500 & 03182500 & 03183500 & 03186500 & 03198500 & 03214000 & \\
\hline 1930 & 243 & 242 & 254 & 248 & 233 & 228 & NO & 233 & 213 & 274 & 235 & 239 & 229 & PR & 228 & 238 \\
\hline 1931 & 232 & 236 & 208 & 169 & 226 & 225 & NO & 228 & 229 & 245 & 261 & 244 & 268 & 184 & 172 & 223 \\
\hline 1932 & 223 & 224 & 199 & 166 & 225 & 214 & PR & 229 & 237 & 273 & 225 & 233 & 263 & 243 & 228 & 227 \\
\hline 1933 & 326 & 317 & 321 & 351 & 297 & 291 & 274 & 309 & 301 & 255 & 305 & 311 & 299 & 241 & 213 & 294 \\
\hline 1934 & 223 & 218 & 193 & 184 & 248 & 245 & 197 & 255 & 226 & 213 & 216 & 214 & 238 & 218 & 183 & 218 \\
\hline 1935 & 329 & 321 & 275 & 330 & 294 & 288 & 246 & 315 & 306 & 295 & 325 & 327 & 316 & 298 & 293 & 304 \\
\hline 1936 & 267 & 266 & 260 & 305 & 249 & 229 & 212 & 233 & 246 & 242 & 257 & 251 & 199 & 203 & 214 & 242 \\
\hline 1937 & 294 & 294 & 278 & 321 & 273 & 278 & 251 & 278 & 287 & 307 & 306 & 288 & 287 & 271 & 250 & 284 \\
\hline 1938 & 329 & 327 & 297 & 329 & 309 & 306 & 261 & 310 & 302 & 318 & 323 & 325 & 278 & 312 & 325 & 310 \\
\hline 1939 & 291 & 284 & 266 & 274 & 257 & 232 & 225 & 267 & 281 & 253 & 272 & 272 & 238 & 236 & 274 & 261 \\
\hline 1940 & 254 & 265 & 295 & 295 & 249 & 254 & 245 & 273 & 259 & 266 & 254 & 242 & 226 & 209 & 214 & 253 \\
\hline 1941 & 294 & 301 & 300 & 300 & 263 & 273 & 268 & 295 & 290 & 295 & 280 & 273 & 244 & 203 & 175 & 270 \\
\hline 1942 & 266 & 256 & 223 & 218 & 301 & 302 & 296 & 296 & 298 & 307 & 284 & 278 & 274 & 268 & 231 & 273 \\
\hline 1943 & 311 & 311 & 265 & 319 & 312 & 324 & 323 & 295 & 307 & 279 & 319 & 318 & 305 & 280 & 279 & 303 \\
\hline 1944 & 195 & 189 & 206 & 170 & 230 & 236 & 219 & 210 & 222 & 236 & 215 & 209 & 221 & 190 & 175 & 208 \\
\hline 1945 & 319 & 310 & 297 & 337 & 313 & 310 & 288 & 322 & 330 & 316 & 293 & 279 & 294 & 259 & 274 & 303 \\
\hline 1946 & 273 & 280 & 303 & 313 & 277 & 273 & 264 & 278 & 275 & 272 & 271 & 265 & 258 & 239 & 256 & 273 \\
\hline 1947 & 233 & 213 & 244 & 209 & 250 & 266 & 280 & 233 & 247 & 271 & 229 & 231 & 260 & 235 & 225 & 242 \\
\hline 1948 & 310 & 314 & 246 & 307 & 282 & 297 & 288 & 278 & 279 & 300 & 329 & 331 & 309 & 247 & 240 & 290 \\
\hline 1949 & 362 & 359 & 349 & 365 & 274 & 266 & 254 & 290 & 294 & 246 & 332 & 331 & 306 & 243 & 243 & 301 \\
\hline 1950 & 317 & 305 & 303 & 323 & 322 & 324 & 270 & 303 & 310 & 303 & 316 & 329 & 341 & 331 & 328 & 315 \\
\hline 1951 & 312 & 315 & 305 & 323 & 279 & 283 & 267 & 279 & 287 & 286 & 295 & 294 & 292 & 297 & 315 & 295 \\
\hline 1952 & 253 & 257 & 266 & 303 & 225 & 237 & 246 & 214 & 226 & 237 & 232 & 243 & 229 & 277 & 279 & 248 \\
\hline 1953 & 230 & 235 & 231 & 269 & 220 & 212 & 193 & 214 & 218 & 185 & 220 & 223 & 211 & 237 & 239 & 222 \\
\hline 1954 & 208 & 209 & 191 & 190 & 258 & 262 & 217 & 258 & 267 & 221 & 263 & 260 & 261 & 215 & 215 & 233 \\
\hline 1955 & 301 & 309 & 324 & 318 & 274 & 262 & 273 & 278 & 281 & 277 & 272 & 267 & 250 & 280 & 237 & 280 \\
\hline 1956 & 248 & 253 & 220 & 202 & 290 & 311 & 305 & 286 & 281 & 326 & 257 & 245 & 268 & 209 & 220 & 261 \\
\hline 1957 & 257 & 240 & 229 & 263 & 247 & 263 & 235 & 251 & 257 & 241 & 282 & 297 & 274 & 222 & 261 & 255 \\
\hline 1958 & 283 & 287 & 278 & 305 & 310 & 321 & 318 & 293 & 299 & 308 & 318 & 329 & 299 & 301 & 321 & 305 \\
\hline 1959 & 177 & 178 & 180 & 177 & 232 & 258 & 271 & 214 & 232 & 243 & 205 & 204 & 231 & 188 & 201 & 213 \\
\hline 1960 & 283 & 280 & 322 & 320 & 270 & 270 & 251 & 279 & 292 & 253 & 287 & 288 & 293 & 267 & 273 & 282 \\
\hline 1961 & 235 & 232 & 224 & 198 & 301 & 313 & 282 & 278 & 300 & 274 & 284 & 272 & 295 & 263 & 266 & 268 \\
\hline 1962 & 268 & 270 & 240 & 278 & 253 & 259 & 255 & 252 & 268 & 222 & 255 & 262 & 253 & 285 & 281 & 260 \\
\hline 1963 & 246 & 241 & 239 & 205 & 277 & 304 & 238 & 298 & 297 & 265 & 238 & 236 & 280 & 270 & 261 & 260 \\
\hline 1964 & 208 & 205 & 217 & 190 & 218 & 207 & 189 & 220 & 232 & 222 & 196 & 194 & 213 & 180 & 197 & 206 \\
\hline 1965 & 214 & 220 & 225 & 211 & 209 & 200 & 198 & 209 & 211 & 207 & 223 & 226 & 221 & 240 & 262 & 218 \\
\hline 1966 & 159 & 158 & 149 & 127 & 188 & 167 & 162 & 191 & 195 & 218 & 251 & 208 & 270 & 160 & 189 & 186 \\
\hline 1967 & 312 & 321 & 331 & 287 & 290 & 267 & 196 & 314 & 304 & 230 & 308 & 303 & 276 & 321 & 329 & 293 \\
\hline 1968 & 254 & 250 & 281 & 284 & 258 & 247 & 253 & 245 & 248 & 263 & 273 & 288 & 268 & 297 & 294 & 267 \\
\hline 1969 & 262 & 267 & 219 & 255 & 266 & 280 & 247 & 257 & 253 & 260 & 284 & 286 & 293 & 312 & 232 & 265 \\
\hline 1970 & 230 & 264 & 289 & 312 & 269 & 276 & 245 & 289 & 273 & 270 & 230 & 234 & 279 & 227 & 225 & 261 \\
\hline 1971 & 288 & 297 & 312 & 325 & 291 & 285 & 311 & 285 & 287 & 313 & 288 & 294 & 293 & 307 & 327 & 300 \\
\hline 1972 & 343 & 339 & 349 & 366 & 312 & 296 & 316 & 306 & 306 & 285 & 316 & 325 & 312 & 346 & 366 & 326 \\
\hline 1973 & 311 & 329 & 362 & 355 & 318 & 294 & 307 & 309 & 301 & 282 & 297 & 329 & 308 & 323 & 337 & 317 \\
\hline 1974 & 340 & 337 & 315 & 303 & 297 & 304 & 329 & 316 & 307 & 319 & 303 & 319 & 299 & 339 & 339 & 318 \\
\hline 1975 & 322 & 318 & 326 & 309 & 280 & 276 & 340 & 300 & 301 & 324 & 293 & 307 & 283 & 315 & 333 & 308 \\
\hline 1976 & 308 & 298 & 308 & 292 & 253 & 262 & 318 & 275 & 255 & 324 & 284 & 300 & 281 & 273 & 299 & 289 \\
\hline 1977 & 248 & 227 & 247 & 226 & 308 & 303 & 348 & 263 & 263 & 302 & 289 & 292 & 315 & 307 & 361 & 287 \\
\hline 1978 & 318 & 319 & 345 & 327 & 322 & 326 & 353 & 312 & 302 & 347 & 326 & 320 & 309 & 319 & 346 & 326 \\
\hline 1979 & 304 & 311 & 334 & 303 & 307 & 300 & 342 & 308 & 300 & 299 & 304 & 301 & 310 & 308 & 311 & 309 \\
\hline
\end{tabular}


Table 5. Number of days exceeding the annual 75-percent flow duration for 15 selected streamgages in West Virginia, 1930-2011, and their average as a proportion.-Continued

[Average is for full years only. NO, not operated during that water year; PR, operated for part of the year. Flow duration values from Wiley, 2006]

\begin{tabular}{|c|c|c|c|c|c|c|c|c|c|c|c|c|c|c|c|c|}
\hline \multirow{2}{*}{ Water year } & \multicolumn{15}{|c|}{ Streamgage } & \multirow{2}{*}{ Averag } \\
\hline & 01606500 & 01608500 & 01611500 & 01636500 & 03051000 & 03053500 & 03061500 & 03066000 & 03069500 & 03070500 & 03182500 & 03183500 & 03186500 & 03198500 & 03214000 & \\
\hline 1981 & 235 & 257 & 225 & 157 & 294 & 301 & 288 & 288 & 264 & 297 & 238 & 232 & 276 & 285 & 291 & 262 \\
\hline 1983 & 257 & 253 & 232 & 253 & 281 & 280 & 244 & 267 & 263 & 254 & 280 & 278 & 280 & 287 & 298 & 267 \\
\hline 1984 & 309 & 324 & 320 & 334 & 292 & 287 & 309 & 287 & 288 & 295 & 304 & 300 & 293 & 306 & 300 & 303 \\
\hline 1985 & 308 & 312 & 275 & 263 & 280 & 280 & 283 & 308 & 287 & 303 & 288 & 298 & 278 & 287 & 293 & 290 \\
\hline 1988 & 246 & 248 & 250 & 254 & 247 & 242 & 219 & 260 & 258 & 260 & 229 & 221 & 236 & 225 & 177 & 238 \\
\hline 1989 & 313 & 307 & 294 & 240 & 326 & 322 & 339 & 345 & 337 & 322 & 323 & 318 & 331 & 326 & 319 & 317 \\
\hline 1990 & 305 & 305 & 322 & 315 & 323 & 329 & 350 & 317 & 311 & 339 & 307 & 308 & 304 & 319 & 332 & 319 \\
\hline 1991 & 255 & 255 & 261 & 294 & 247 & 235 & 243 & 232 & 258 & 242 & 251 & 253 & 241 & 268 & 294 & 255 \\
\hline 1992 & 274 & 262 & 287 & 243 & 277 & 317 & 254 & 257 & 270 & 290 & 265 & 261 & 277 & 316 & 301 & 277 \\
\hline 1997 & 297 & 303 & 302 & 329 & 293 & 297 & 311 & 292 & 294 & 286 & 288 & 292 & 283 & 338 & 332 & 302 \\
\hline 1998 & 276 & 291 & 291 & 304 & 286 & 281 & 256 & 285 & 285 & 275 & 271 & 276 & 264 & 289 & 274 & 280 \\
\hline 1999 & 161 & 177 & 177 & 179 & 186 & 179 & 165 & 169 & 184 & 184 & 173 & 168 & 173 & 193 & 201 & 178 \\
\hline 2000 & 306 & 331 & 328 & 338 & 315 & 323 & 278 & 321 & 326 & 278 & 328 & 323 & 344 & 323 & 309 & 318 \\
\hline 2001 & 277 & 288 & 301 & 263 & 283 & 287 & 332 & 306 & 284 & 268 & 287 & 285 & 248 & 303 & 267 & 285 \\
\hline 2002 & 190 & 181 & 182 & 91 & 225 & 224 & 246 & 225 & 219 & 238 & 222 & 215 & 222 & 238 & 237 & 210 \\
\hline 2003 & 356 & 357 & 357 & 353 & 341 & 343 & 343 & 347 & 331 & 336 & 342 & 355 & 332 & 354 & 346 & 346 \\
\hline 2004 & 334 & 338 & 354 & 349 & 324 & 341 & 359 & 331 & 328 & 340 & 324 & 318 & 289 & 366 & 366 & 337 \\
\hline 2005 & 336 & 335 & 314 & 331 & 276 & 276 & 284 & 291 & 287 & 278 & 314 & 325 & 294 & 341 & 347 & 309 \\
\hline 2006 & 280 & 297 & 293 & 317 & 285 & 286 & 287 & 291 & 292 & 269 & 266 & 263 & 298 & 317 & 319 & 291 \\
\hline 2007 & 278 & 288 & 291 & 295 & 308 & 292 & 299 & 327 & 321 & 276 & 304 & 290 & 305 & 294 & 314 & 299 \\
\hline 2008 & 277 & 291 & 261 & 225 & 276 & 266 & 299 & 290 & 281 & 290 & 255 & 244 & 249 & 293 & 272 & 271 \\
\hline 75th percentile & 246 & 243 & 239 & 233 & 249 & 254 & 245 & 255 & 255 & 248 & 251 & 244 & 249 & 240 & 237 & 255 \\
\hline Minimum & 159 & 158 & 149 & 91 & 186 & 167 & 162 & 169 & 184 & 184 & 173 & 168 & 173 & 160 & 172 & 178 \\
\hline
\end{tabular}


Table 6. Number of days exceeding the relevant seasonal 75-percent flow duration at 15 selected streamgages in West Virginia, by season, water years 1930-2011, and their average as a proportion.

[Average is for full years only. NO, not operated during that season; PR, operated for part of the season; fall, October 1-December 31; winter, January 1March 31; spring, April 1-June 30; summer, July 1-September 30. Flow duration values from Wiley, 2006]

\begin{tabular}{|c|c|c|c|c|c|c|c|c|c|c|c|c|c|c|c|c|c|}
\hline \multirow{2}{*}{$\begin{array}{c}\text { Water } \\
\text { year }\end{array}$} & \multirow{2}{*}{ Season } & \multicolumn{15}{|c|}{ Streamgage } & \multirow{2}{*}{ Average } \\
\hline & & 01606500 & 01608500 & 01611500 & 01636500 & 03051000 & 03053500 & 03061500 & 03066000 & 03069500 & 03070500 & 03182500 & 03183500 & 03186500 & 03198500 & 03214000 & \\
\hline \multirow[t]{4}{*}{1930} & Fall & 91 & 91 & 91 & 92 & 88 & 89 & NO & 91 & 88 & 91 & 91 & 92 & 88 & $\mathrm{NO}$ & 91 & 90 \\
\hline & Winter & 65 & 66 & 58 & 72 & 67 & 65 & NO & 66 & 56 & 72 & 58 & 55 & 87 & NO & 62 & 65 \\
\hline & Spring & 30 & 30 & 33 & 24 & 39 & 35 & NO & 33 & 32 & 67 & 36 & 31 & 33 & PR & 28 & 35 \\
\hline & Summer & 0 & 2 & 9 & 7 & 2 & 4 & NO & 7 & 3 & 27 & 2 & 0 & 10 & 3 & 3 & 6 \\
\hline \multirow[t]{4}{*}{1931} & Fall & 11 & 8 & 10 & 4 & 10 & 6 & NO & 17 & 14 & 11 & 12 & 10 & 22 & 0 & 11 & 10 \\
\hline & Winter & 37 & 33 & 5 & 4 & 52 & 52 & NO & 56 & 51 & 44 & 46 & 38 & 62 & 36 & 22 & 38 \\
\hline & Spring & 86 & 85 & 71 & 70 & 82 & 79 & NO & 80 & 85 & 74 & 87 & 84 & 87 & 67 & 64 & 79 \\
\hline & Summer & 90 & 92 & 80 & 79 & 88 & 92 & NO & 74 & 92 & 92 & 92 & 92 & 92 & 65 & 55 & 84 \\
\hline \multirow[t]{4}{*}{1932} & Fall & 32 & 26 & 17 & 2 & 44 & 42 & NO & 55 & 59 & 89 & 42 & 40 & 66 & 39 & 29 & 42 \\
\hline & Winter & 63 & 59 & 45 & 39 & 70 & 68 & NO & 71 & 68 & 67 & 75 & 74 & 79 & 74 & 70 & 66 \\
\hline & Spring & 66 & 64 & 65 & 64 & 55 & 54 & NO & 55 & 56 & 53 & 57 & 64 & 61 & 80 & 67 & 62 \\
\hline & Summer & 44 & 40 & 22 & 26 & 52 & 58 & PR & 50 & 54 & 56 & 56 & 59 & 71 & 53 & 37 & 48 \\
\hline \multirow[t]{4}{*}{1933} & Fall & 80 & 78 & 81 & 82 & 77 & 71 & 57 & 72 & 76 & 58 & 80 & 79 & 78 & 82 & 51 & 73 \\
\hline & Winter & 79 & 79 & 83 & 90 & 81 & 79 & 70 & 70 & 79 & 80 & 83 & 83 & 86 & 81 & 77 & 80 \\
\hline & Spring & 70 & 72 & 76 & 77 & 78 & 72 & 76 & 73 & 75 & 73 & 69 & 71 & 72 & 59 & 67 & 72 \\
\hline & Summer & 92 & 91 & 92 & 92 & 92 & 92 & 73 & 92 & 91 & 77 & 86 & 89 & 91 & 45 & 28 & 82 \\
\hline \multirow[t]{4}{*}{1934} & Fall & 75 & 79 & 78 & 63 & 61 & 72 & 57 & 76 & 65 & 56 & 46 & 44 & 56 & 41 & 23 & 59 \\
\hline & Winter & 45 & 43 & 32 & 28 & 71 & 56 & 48 & 58 & 55 & 54 & 43 & 42 & 48 & 40 & 38 & 47 \\
\hline & Spring & 45 & 42 & 55 & 53 & 62 & 55 & 30 & 43 & 48 & 37 & 45 & 40 & 49 & 47 & 43 & 46 \\
\hline & Summer & 38 & 34 & 48 & 62 & 50 & 56 & 33 & 73 & 64 & 48 & 32 & 53 & 66 & 60 & 66 & 52 \\
\hline \multirow[t]{4}{*}{1935} & Fall & 76 & 71 & 54 & 85 & 64 & 65 & 45 & 73 & 71 & 64 & 74 & 82 & 76 & 74 & 85 & 71 \\
\hline & Winter & 86 & 81 & 69 & 89 & 81 & 75 & 65 & 71 & 75 & 79 & 85 & 86 & 80 & 59 & 80 & 77 \\
\hline & Spring & 78 & 78 & 73 & 81 & 73 & 79 & 78 & 79 & 80 & 73 & 78 & 78 & 85 & 84 & 88 & 79 \\
\hline & Summer & 92 & 92 & 82 & 91 & 90 & 81 & 60 & 92 & 86 & 89 & 92 & 92 & 86 & 70 & 61 & 84 \\
\hline \multirow[t]{4}{*}{1936} & Fall & 91 & 87 & 63 & 90 & 72 & 70 & 58 & 72 & 71 & 55 & 68 & 66 & 58 & 59 & 57 & 69 \\
\hline & Winter & 83 & 89 & 90 & 89 & 69 & 75 & 80 & 71 & 70 & 71 & 88 & 77 & 81 & 59 & 72 & 78 \\
\hline & Spring & 57 & 49 & 60 & 67 & 56 & 34 & 42 & 37 & 37 & 46 & 53 & 44 & 33 & 25 & 40 & 45 \\
\hline & Summer & 63 & 56 & 40 & 81 & 54 & 45 & 27 & 56 & 60 & 74 & 67 & 66 & 25 & 29 & 35 & 52 \\
\hline 1937 & Fall & 78 & 77 & 55 & 90 & 76 & 67 & 46 & 71 & 74 & 77 & 84 & 85 & 78 & 51 & 52 & 71 \\
\hline & Winter & 90 & 90 & 90 & 90 & 80 & 77 & 67 & 77 & 81 & 78 & 87 & 88 & 83 & 84 & 86 & 83 \\
\hline & Spring & 69 & 72 & 63 & 91 & 78 & 86 & 90 & 85 & 83 & 74 & 72 & 65 & 58 & 58 & 54 & 73 \\
\hline & Summer & 80 & 85 & 88 & 92 & 76 & 79 & 53 & 61 & 69 & 82 & 83 & 85 & 88 & 77 & 63 & 77 \\
\hline 1938 & Fall & 90 & 92 & 92 & 92 & 89 & 89 & 80 & 82 & 81 & 88 & 90 & 89 & 84 & 77 & 88 & 87 \\
\hline & Winter & 75 & 71 & 39 & 84 & 75 & 72 & 82 & 68 & 74 & 74 & 63 & 68 & 75 & 71 & 69 & 71 \\
\hline & Spring & 75 & 73 & 69 & 63 & 77 & 80 & 60 & 85 & 81 & 67 & 68 & 72 & 66 & 71 & 77 & 72 \\
\hline & Summer & 82 & 81 & 61 & 88 & 69 & 66 & 35 & 81 & 74 & 81 & 78 & 88 & 77 & 83 & 83 & 75 \\
\hline 1939 & Fall & 57 & 58 & 44 & 65 & 55 & 51 & 31 & 53 & 56 & 49 & 55 & 58 & 59 & 56 & 59 & 54 \\
\hline & Winter & 74 & 74 & 67 & 67 & 60 & 68 & 67 & 69 & 68 & 67 & 70 & 67 & 68 & 69 & 71 & 68 \\
\hline & Spring & 72 & 70 & 68 & 59 & 65 & 44 & 63 & 54 & 68 & 62 & 66 & 63 & 47 & 44 & 52 & 60 \\
\hline & Summer & 82 & 82 & 81 & 80 & 63 & 53 & 54 & 80 & 68 & 54 & 72 & 73 & 56 & 38 & 57 & 66 \\
\hline 1940 & Fall & 71 & 76 & 74 & 72 & 45 & 40 & 42 & 67 & 53 & 62 & 44 & 23 & 17 & 0 & 5 & 46 \\
\hline & Winter & 51 & 49 & 56 & 51 & 47 & 48 & 51 & 54 & 54 & 57 & 37 & 34 & 49 & 19 & 16 & 45 \\
\hline & Spring & 86 & 86 & 85 & 91 & 91 & 91 & 82 & 80 & 89 & 89 & 90 & 85 & 85 & 79 & 59 & 85 \\
\hline & Summer & 92 & 92 & 82 & 92 & 66 & 61 & 69 & 76 & 70 & 65 & 90 & 92 & 84 & 80 & 84 & 80 \\
\hline 1941 & Fall & 92 & 92 & 92 & 92 & 76 & 75 & 63 & 86 & 79 & 66 & 73 & 70 & 60 & 31 & 19 & 71 \\
\hline & Winter & 47 & 49 & 64 & 71 & 49 & 52 & 40 & 49 & 49 & 62 & 57 & 56 & 50 & 24 & 14 & 49 \\
\hline & Spring & 39 & 38 & 38 & 36 & 43 & 49 & 49 & 46 & 50 & 56 & 42 & 38 & 41 & 40 & 33 & 43 \\
\hline & Summer & 72 & 74 & 71 & 69 & 65 & 62 & 73 & 80 & 76 & 90 & 73 & 70 & 65 & 61 & 48 & 70 \\
\hline 1942 & Fall & 38 & 31 & 18 & 17 & 51 & 56 & 68 & 64 & 52 & 80 & 48 & 49 & 52 & 31 & 38 & 46 \\
\hline & Winter & 41 & 36 & 25 & 25 & 47 & 50 & 56 & 51 & 50 & 55 & 57 & 52 & 56 & 32 & 25 & 44 \\
\hline & Spring & 60 & 58 & 57 & 58 & 67 & 60 & 60 & 55 & 64 & 65 & 67 & 69 & 66 & 41 & 31 & 59 \\
\hline & Summer & 89 & 87 & 79 & 86 & 92 & 92 & 91 & 92 & 92 & 91 & 84 & 92 & 92 & 92 & 84 & 89 \\
\hline 1943 & Fall & 92 & 92 & 88 & 92 & 92 & 92 & 92 & 92 & 92 & 91 & 92 & 92 & 91 & 92 & 92 & 92 \\
\hline & Winter & 88 & 88 & 90 & 90 & 79 & 81 & 77 & 86 & 82 & 79 & 81 & 77 & 80 & 85 & 76 & 83 \\
\hline & Spring & 77 & 77 & 72 & 87 & 63 & 69 & 77 & 68 & 64 & 72 & 72 & 72 & 64 & 66 & 60 & 71 \\
\hline & Summer & 71 & 72 & 40 & 68 & 77 & 77 & 74 & 69 & 73 & 68 & 73 & 71 & 76 & 23 & 28 & 64 \\
\hline
\end{tabular}


Table 6. Number of days exceeding the relevant seasonal 75-percent flow duration at 15 selected streamgages in West Virginia, by season, water years 1930-2011, and their average as a proportion.-Continued

[Average is for full years only. NO, not operated during that season; PR, operated for part of the season; fall, October 1-December 31; winter, January 1March 31; spring, April 1-June 30; summer, July 1-September 30. Flow duration values from Wiley, 2006]

\begin{tabular}{|c|c|c|c|c|c|c|c|c|c|c|c|c|c|c|c|c|c|}
\hline \multirow{2}{*}{$\begin{array}{l}\text { Water } \\
\text { year }\end{array}$} & \multirow{2}{*}{ Season } & \multicolumn{15}{|c|}{ Streamgage } & \multirow{2}{*}{ Average } \\
\hline & & 01606500 & 01608500 & 01611500 & 01636500 & 03051000 & 03053500 & 03061500 & 03066000 & 03069500 & 03070500 & 03182500 & 03183500 & 03186500 & 03198500 & 03214000 & \\
\hline \multirow[t]{4}{*}{1944} & Fall & 27 & 26 & 46 & 25 & 56 & 56 & 53 & 33 & 38 & 55 & 50 & 52 & 62 & 17 & 19 & 41 \\
\hline & Winter & 50 & 47 & 55 & 40 & 66 & 65 & 51 & 67 & 66 & 61 & 55 & 55 & 60 & 57 & 50 & 56 \\
\hline & Spring & 73 & 70 & 65 & 67 & 85 & 90 & 72 & 86 & 83 & 80 & 69 & 68 & 64 & 61 & 67 & 73 \\
\hline & Summer & 56 & 52 & 24 & 39 & 32 & 28 & 51 & 40 & 41 & 58 & 46 & 28 & 4 & 18 & 12 & 35 \\
\hline \multirow[t]{4}{*}{1945} & Fall & 92 & 92 & 75 & 92 & 87 & 91 & 91 & 92 & 92 & 90 & 77 & 63 & 63 & 50 & 55 & 80 \\
\hline & Winter & 77 & 81 & 86 & 78 & 77 & 77 & 75 & 67 & 80 & 73 & 70 & 72 & 71 & 77 & 73 & 76 \\
\hline & Spring & 72 & 66 & 65 & 55 & 84 & 79 & 72 & 81 & 86 & 78 & 79 & 79 & 81 & 84 & 87 & 77 \\
\hline & Summer & 91 & 89 & 92 & 89 & 84 & 87 & 64 & 92 & 86 & 87 & 87 & 90 & 85 & 71 & 68 & 84 \\
\hline \multirow[t]{4}{*}{1946} & Fall & 89 & 92 & 92 & 92 & 77 & 80 & 77 & 78 & 79 & 92 & 75 & 75 & 70 & 78 & 71 & 81 \\
\hline & Winter & 83 & 82 & 88 & 90 & 72 & 70 & 67 & 71 & 76 & 68 & 81 & 81 & 77 & 79 & 88 & 78 \\
\hline & Spring & 77 & 77 & 79 & 82 & 81 & 84 & 82 & 73 & 74 & 76 & 70 & 70 & 70 & 63 & 75 & 76 \\
\hline & Summer & 44 & 45 & 59 & 74 & 44 & 21 & 46 & 44 & 39 & 20 & 42 & 39 & 32 & 17 & 41 & 40 \\
\hline \multirow[t]{4}{*}{1947} & Fall & 16 & 17 & 38 & 32 & 33 & 37 & 53 & 23 & 28 & 33 & 23 & 20 & 41 & 21 & 37 & 30 \\
\hline & Winter & 45 & 42 & 43 & 44 & 56 & 62 & 68 & 60 & 50 & 55 & 54 & 55 & 51 & 52 & 58 & 53 \\
\hline & Spring & 73 & 72 & 52 & 48 & 74 & 71 & 72 & 70 & 75 & 70 & 81 & 66 & 79 & 65 & 44 & 67 \\
\hline & Summer & 79 & 72 & 73 & 57 & 88 & 89 & 87 & 72 & 88 & 92 & 90 & 88 & 79 & 79 & 70 & 80 \\
\hline \multirow[t]{4}{*}{1948} & Fall & 63 & 61 & 48 & 73 & 55 & 53 & 66 & 59 & 55 & 61 & 69 & 77 & 61 & 57 & 59 & 61 \\
\hline & Winter & 53 & 53 & 53 & 47 & 63 & 65 & 62 & 63 & 63 & 62 & 56 & 55 & 59 & 55 & 51 & 57 \\
\hline & Spring & 70 & 72 & 63 & 79 & 76 & 81 & 71 & 84 & 83 & 84 & 80 & 74 & 82 & 55 & 57 & 74 \\
\hline & Summer & 92 & 92 & 80 & 92 & 92 & 92 & 76 & 83 & 90 & 87 & 92 & 92 & 92 & 61 & 61 & 85 \\
\hline \multirow[t]{4}{*}{1949} & Fall & 92 & 92 & 88 & 92 & 92 & 77 & 65 & 88 & 89 & 84 & 92 & 92 & 92 & 61 & 56 & 83 \\
\hline & Winter & 90 & 90 & 90 & 90 & 86 & 86 & 88 & 81 & 90 & 90 & 88 & 87 & 85 & 87 & 84 & 87 \\
\hline & Spring & 76 & 76 & 76 & 79 & 51 & 53 & 50 & 55 & 56 & 50 & 73 & 70 & 66 & 66 & 60 & 64 \\
\hline & Summer & 92 & 92 & 92 & 92 & 83 & 88 & 70 & 77 & 86 & 50 & 92 & 90 & 90 & 60 & 57 & 81 \\
\hline \multirow[t]{4}{*}{1950} & Fall & 92 & 92 & 92 & 92 & 78 & 83 & 59 & 70 & 71 & 61 & 78 & 79 & 92 & 80 & 80 & 80 \\
\hline & Winter & 86 & 83 & 73 & 64 & 88 & 90 & 85 & 88 & 90 & 90 & 82 & 88 & 90 & 89 & 80 & 84 \\
\hline & Spring & 79 & 82 & 79 & 79 & 91 & 91 & 75 & 85 & 88 & 91 & 87 & 91 & 91 & 91 & 91 & 86 \\
\hline & Summer & 87 & 86 & 73 & 90 & 92 & 90 & 90 & 76 & 89 & 91 & 92 & 92 & 92 & 92 & 92 & 88 \\
\hline 1951 & Fall & 92 & 92 & 92 & 92 & 85 & 85 & 89 & 89 & 87 & 90 & 92 & 92 & 90 & 92 & 92 & 90 \\
\hline & Winter & 87 & 87 & 90 & 90 & 85 & 87 & 88 & 82 & 85 & 86 & 85 & 85 & 84 & 76 & 72 & 85 \\
\hline & Spring & 90 & 89 & 86 & 89 & 86 & 83 & 77 & 79 & 78 & 76 & 77 & 90 & 87 & 89 & 84 & 84 \\
\hline & Summer & 85 & 87 & 75 & 76 & 55 & 55 & 37 & 44 & 52 & 56 & 68 & 70 & 62 & 65 & 83 & 65 \\
\hline 1952 & Fall & 62 & 61 & 61 & 45 & 58 & 60 & 41 & 48 & 48 & 45 & 51 & 55 & 59 & 61 & 69 & 55 \\
\hline & Winter & 85 & 86 & 90 & 91 & 71 & 71 & 65 & 76 & 77 & 80 & 82 & 84 & 79 & 83 & 90 & 81 \\
\hline & Spring & 69 & 71 & 71 & 85 & 66 & 69 & 67 & 68 & 69 & 70 & 65 & 65 & 67 & 67 & 71 & 69 \\
\hline & Summer & 72 & 79 & 89 & 92 & 39 & 39 & 66 & 25 & 37 & 63 & 57 & 66 & 34 & 71 & 60 & 59 \\
\hline 1953 & Fall & 43 & 44 & 57 & 88 & 28 & 28 & 44 & 35 & 31 & 35 & 35 & 35 & 29 & 41 & 43 & 41 \\
\hline & Winter & 83 & 83 & 90 & 90 & 79 & 80 & 80 & 82 & 81 & 81 & 81 & 83 & 81 & 83 & 79 & 82 \\
\hline & Spring & 72 & 70 & 72 & 80 & 67 & 64 & 54 & 68 & 70 & 54 & 73 & 71 & 70 & 82 & 87 & 70 \\
\hline & Summer & 36 & 34 & 51 & 64 & 38 & 43 & 21 & 26 & 30 & 0 & 17 & 22 & 25 & 46 & 52 & 34 \\
\hline 1954 & Fall & 20 & 18 & 39 & 35 & 22 & 25 & 14 & 29 & 28 & 5 & 26 & 25 & 27 & 17 & 10 & 23 \\
\hline & Winter & 52 & 49 & 41 & 46 & 64 & 64 & 41 & 66 & 67 & 57 & 57 & 56 & 65 & 38 & 36 & 53 \\
\hline & Spring & 76 & 74 & 72 & 73 & 69 & 65 & 72 & 74 & 81 & 71 & 81 & 79 & 80 & 64 & 68 & 73 \\
\hline & Summer & 71 & 73 & 48 & 27 & 91 & 92 & 82 & 84 & 89 & 79 & 92 & 90 & 85 & 70 & 69 & 76 \\
\hline 1955 & Fall & 82 & 78 & 78 & 78 & 91 & 91 & 89 & 88 & 91 & 91 & 87 & 83 & 78 & 85 & 73 & 84 \\
\hline & Winter & 74 & 75 & 70 & 73 & 70 & 76 & 78 & 71 & 71 & 72 & 75 & 71 & 72 & 85 & 79 & 74 \\
\hline & Spring & 68 & 71 & 83 & 68 & 50 & 53 & 70 & 60 & 57 & 55 & 59 & 55 & 56 & 69 & 58 & 62 \\
\hline & Summer & 88 & 83 & 87 & 90 & 40 & 44 & 57 & 57 & 59 & 60 & 46 & 44 & 30 & 42 & 43 & 58 \\
\hline 1956 & Fall & 57 & 60 & 74 & 82 & 53 & 55 & 66 & 54 & 47 & 74 & 46 & 34 & 41 & 33 & 38 & 54 \\
\hline & Winter & 62 & 61 & 59 & 53 & 63 & 63 & 63 & 63 & 63 & 63 & 62 & 61 & 64 & 62 & 62 & 62 \\
\hline & Spring & 79 & 77 & 62 & 30 & 85 & 83 & 91 & 91 & 89 & 84 & 85 & 81 & 85 & 76 & 76 & 78 \\
\hline & Summer & 92 & 92 & 92 & 64 & 92 & 92 & 92 & 92 & 92 & 92 & 92 & 92 & 90 & 77 & 91 & 89 \\
\hline 1957 & Fall & 82 & 85 & 78 & 84 & 85 & 84 & 92 & 85 & 81 & 92 & 84 & 92 & 87 & 76 & 90 & 85 \\
\hline & Winter & 77 & 75 & 71 & 68 & 75 & 72 & 69 & 80 & 79 & 84 & 77 & 79 & 82 & 76 & 77 & 76 \\
\hline & Spring & 67 & 66 & 64 & 77 & 54 & 69 & 44 & 52 & 63 & 48 & 64 & 64 & 58 & 34 & 49 & 58 \\
\hline & Summer & 37 & 33 & 12 & 24 & 20 & 27 & 11 & 32 & 31 & 22 & 59 & 61 & 70 & 22 & 53 & 34 \\
\hline
\end{tabular}


Table 6. Number of days exceeding the relevant seasonal 75-percent flow duration at 15 selected streamgages in West Virginia, by season, water years 1930-2011, and their average as a proportion.-Continued

[Average is for full years only. NO, not operated during that season; PR, operated for part of the season; fall, October 1-December 31; winter, January 1March 31; spring, April 1-June 30; summer, July 1-September 30. Flow duration values from Wiley, 2006]

\begin{tabular}{|c|c|c|c|c|c|c|c|c|c|c|c|c|c|c|c|c|c|}
\hline \multirow{2}{*}{$\begin{array}{c}\text { Water } \\
\text { year }\end{array}$} & \multirow{2}{*}{ Season } & \multicolumn{15}{|c|}{ Streamgage } & \multirow{2}{*}{ Average } \\
\hline & & 01606500 & 01608500 & 01611500 & 01636500 & 03051000 & 03053500 & 03061500 & 03066000 & 03069500 & 03070500 & 03182500 & 03183500 & 03186500 & 03198500 & 03214000 & \\
\hline \multirow[t]{4}{*}{1958} & Fall & 75 & 85 & 66 & 66 & 78 & 80 & 70 & 78 & 78 & 77 & 86 & 92 & 81 & 74 & 84 & 78 \\
\hline & Winter & 62 & 70 & 67 & 77 & 55 & 66 & 57 & 55 & 49 & 55 & 60 & 72 & 56 & 69 & 68 & 63 \\
\hline & Spring & 60 & 59 & 67 & 81 & 75 & 78 & 66 & 64 & 68 & 68 & 63 & 61 & 66 & 83 & 84 & 70 \\
\hline & Summer & 79 & 83 & 83 & 92 & 86 & 89 & 92 & 91 & 85 & 92 & 91 & 92 & 85 & 85 & 92 & 88 \\
\hline \multirow[t]{4}{*}{1959} & Fall & 19 & 8 & 21 & 26 & 61 & 68 & 92 & 58 & 54 & 84 & 54 & 53 & 60 & 65 & 92 & 54 \\
\hline & Winter & 34 & 25 & 19 & 13 & 64 & 60 & 69 & 69 & 73 & 77 & 55 & 50 & 68 & 57 & 63 & 53 \\
\hline & Spring & 70 & 71 & 73 & 63 & 72 & 73 & 56 & 59 & 65 & 59 & 72 & 72 & 68 & 63 & 64 & 67 \\
\hline & Summer & 30 & 30 & 53 & 58 & 43 & 54 & 56 & 25 & 42 & 24 & 47 & 43 & 47 & 19 & 31 & 40 \\
\hline \multirow[t]{4}{*}{1960} & Fall & 81 & 86 & 92 & 92 & 69 & 69 & 65 & 73 & 74 & 70 & 81 & 82 & 74 & 72 & 87 & 78 \\
\hline & Winter & 73 & 78 & 85 & 78 & 72 & 73 & 69 & 51 & 55 & 55 & 64 & 69 & 52 & 76 & 85 & 69 \\
\hline & Spring & 73 & 73 & 89 & 86 & 62 & 64 & 62 & 67 & 67 & 54 & 68 & 70 & 76 & 49 & 53 & 68 \\
\hline & Summer & 79 & 69 & 89 & 92 & 83 & 88 & 82 & 79 & 83 & 64 & 76 & 78 & 86 & 66 & 70 & 79 \\
\hline \multirow[t]{4}{*}{1961} & Fall & 45 & 42 & 20 & 14 & 75 & 74 & 48 & 75 & 73 & 43 & 63 & 68 & 73 & 67 & 78 & 57 \\
\hline & Winter & 46 & 48 & 55 & 44 & 70 & 66 & 65 & 58 & 58 & 67 & 55 & 55 & 59 & 62 & 61 & 58 \\
\hline & Spring & 88 & 84 & 89 & 82 & 86 & 84 & 91 & 86 & 89 & 89 & 83 & 81 & 80 & 77 & 79 & 85 \\
\hline & Summer & 73 & 84 & 77 & 78 & 90 & 92 & 92 & 84 & 83 & 92 & 92 & 92 & 92 & 69 & 76 & 84 \\
\hline \multirow[t]{4}{*}{1962} & Fall & 76 & 75 & 45 & 71 & 81 & 91 & 92 & 59 & 79 & 74 & 78 & 81 & 78 & 80 & 81 & 76 \\
\hline & Winter & 82 & 75 & 54 & 76 & 84 & 83 & 83 & 79 & 82 & 72 & 79 & 86 & 75 & 90 & 85 & 79 \\
\hline & Spring & 77 & 80 & 79 & 86 & 56 & 50 & 50 & 74 & 67 & 44 & 46 & 50 & 58 & 64 & 67 & 63 \\
\hline & Summer & 40 & 47 & 53 & 54 & 33 & 55 & 29 & 50 & 49 & 15 & 33 & 51 & 38 & 61 & 82 & 46 \\
\hline \multirow[t]{4}{*}{1963} & Fall & 72 & 71 & 66 & 53 & 81 & 92 & 70 & 70 & 75 & 75 & 68 & 67 & 69 & 71 & 91 & 73 \\
\hline & Winter & 44 & 47 & 42 & 50 & 63 & 68 & 65 & 66 & 54 & 62 & 53 & 53 & 71 & 76 & 88 & 60 \\
\hline & Spring & 56 & 56 & 54 & 39 & 63 & 65 & 55 & 71 & 64 & 70 & 57 & 49 & 70 & 63 & 45 & 58 \\
\hline & Summer & 46 & 35 & 16 & 10 & 70 & 77 & 66 & 92 & 83 & 48 & 59 & 57 & 80 & 65 & 43 & 56 \\
\hline \multirow[t]{4}{*}{1964} & Fall & 50 & 48 & 45 & 34 & 50 & 54 & 23 & 55 & 54 & 41 & 49 & 47 & 57 & 43 & 39 & 46 \\
\hline & Winter & 74 & 85 & 87 & 84 & 67 & 71 & 67 & 68 & 62 & 75 & 67 & 69 & 68 & 72 & 69 & 72 \\
\hline & Spring & 47 & 49 & 56 & 51 & 50 & 42 & 51 & 51 & 52 & 61 & 41 & 40 & 44 & 36 & 46 & 48 \\
\hline & Summer & 32 & 16 & 18 & 7 & 52 & 46 & 48 & 34 & 57 & 48 & 24 & 28 & 34 & 8 & 30 & 32 \\
\hline 1965 & Fall & 65 & 72 & 68 & 54 & 54 & 53 & 43 & 63 & 62 & 47 & 54 & 59 & 53 & 69 & 76 & 59 \\
\hline & Winter & 89 & 90 & 87 & 87 & 71 & 68 & 72 & 89 & 74 & 71 & 71 & 72 & 66 & 72 & 80 & 77 \\
\hline & Spring & 50 & 52 & 53 & 51 & 43 & 44 & 49 & 41 & 42 & 48 & 56 & 59 & 47 & 46 & 60 & 49 \\
\hline & Summer & 21 & 22 & 10 & 14 & 32 & 38 & 23 & 13 & 31 & 30 & 39 & 35 & 44 & 57 & 50 & 31 \\
\hline 1966 & Fall & 13 & 7 & 0 & 1 & 24 & 15 & 61 & 34 & 40 & 68 & 92 & 87 & 89 & 9 & 20 & 37 \\
\hline & Winter & 37 & 35 & 21 & 25 & 36 & 34 & 33 & 48 & 49 & 48 & 46 & 40 & 48 & 19 & 20 & 36 \\
\hline & Spring & 45 & 43 & 46 & 44 & 56 & 55 & 54 & 51 & 51 & 56 & 64 & 53 & 54 & 50 & 46 & 51 \\
\hline & Summer & 23 & 22 & 25 & 19 & 56 & 47 & 12 & 37 & 52 & 16 & 51 & 40 & 65 & 47 & 76 & 39 \\
\hline 1967 & Fall & 92 & 92 & 92 & 92 & 92 & 85 & 50 & 92 & 92 & 56 & 92 & 92 & 92 & 92 & 92 & 86 \\
\hline & Winter & 86 & 86 & 81 & 88 & 71 & 62 & 46 & 69 & 74 & 64 & 87 & 84 & 75 & 81 & 88 & 76 \\
\hline & Spring & 71 & 69 & 77 & 49 & 69 & 67 & 65 & 72 & 68 & 66 & 73 & 74 & 69 & 72 & 77 & 69 \\
\hline & Summer & 60 & 69 & 92 & 82 & 65 & 62 & 37 & 81 & 70 & 57 & 69 & 72 & 62 & 64 & 78 & 68 \\
\hline 1968 & Fall & 90 & 90 & 92 & 92 & 92 & 84 & 66 & 75 & 87 & 79 & 92 & 92 & 82 & 78 & 85 & 85 \\
\hline & Winter & 50 & 68 & 61 & 79 & 54 & 54 & 39 & 45 & 46 & 43 & 48 & 49 & 43 & 60 & 60 & 53 \\
\hline & Spring & 60 & 49 & 63 & 47 & 65 & 71 & 75 & 58 & 56 & 73 & 80 & 79 & 71 & 76 & 89 & 67 \\
\hline & Summer & 34 & 23 & 53 & 64 & 42 & 50 & 90 & 53 & 34 & 33 & 20 & 51 & 49 & 89 & 83 & 51 \\
\hline 1969 & Fall & 56 & 55 & 61 & 57 & 61 & 60 & 54 & 59 & 61 & 56 & 59 & 65 & 76 & 86 & 60 & 62 \\
\hline & Winter & 32 & 27 & 18 & 36 & 43 & 43 & 34 & 43 & 43 & 41 & 40 & 43 & 40 & 41 & 32 & 37 \\
\hline & Spring & 47 & 39 & 30 & 17 & 54 & 60 & 58 & 52 & 51 & 54 & 57 & 54 & 54 & 64 & 56 & 50 \\
\hline & Summer & 85 & 86 & 68 & 83 & 92 & 92 & 72 & 87 & 88 & 83 & 85 & 88 & 92 & 92 & 46 & 83 \\
\hline 1970 & Fall & 71 & 87 & 60 & 92 & 69 & 89 & 47 & 74 & 73 & 59 & 67 & 74 & 75 & 64 & 29 & 69 \\
\hline & Winter & 76 & 84 & 83 & 90 & 74 & 70 & 65 & 77 & 73 & 67 & 71 & 71 & 69 & 74 & 60 & 74 \\
\hline & Spring & 45 & 45 & 63 & 55 & 52 & 49 & 73 & 46 & 45 & 63 & 47 & 47 & 61 & 51 & 56 & 53 \\
\hline & Summer & 64 & 79 & 68 & 68 & 92 & 90 & 80 & 89 & 89 & 86 & 73 & 67 & 89 & 59 & 70 & 78 \\
\hline 1971 & Fall & 71 & 68 & 70 & 65 & 76 & 73 & 77 & 72 & 72 & 77 & 70 & 69 & 72 & 67 & 79 & 72 \\
\hline & Winter & 87 & 87 & 90 & 90 & 86 & 84 & 75 & 85 & 85 & 87 & 87 & 86 & 84 & 85 & 81 & 85 \\
\hline & Spring & 77 & 76 & 88 & 90 & 63 & 59 & 68 & 69 & 62 & 64 & 66 & 76 & 64 & 84 & 91 & 73 \\
\hline & Summer & 86 & 92 & 92 & 92 & 88 & 78 & 92 & 66 & 78 & 92 & 85 & 81 & 85 & 92 & 92 & 86 \\
\hline
\end{tabular}


Table 6. Number of days exceeding the relevant seasonal 75-percent flow duration at 15 selected streamgages in West Virginia, by season, water years 1930-2011, and their average as a proportion.-Continued

[Average is for full years only. NO, not operated during that season; PR, operated for part of the season; fall, October 1-December 31; winter, January 1March 31; spring, April 1-June 30; summer, July 1-September 30. Flow duration values from Wiley, 2006]

\begin{tabular}{|c|c|c|c|c|c|c|c|c|c|c|c|c|c|c|c|c|c|}
\hline \multirow{2}{*}{$\begin{array}{c}\text { Water } \\
\text { year }\end{array}$} & \multirow{2}{*}{ Season } & \multicolumn{15}{|c|}{ Streamgage } & \multirow{2}{*}{ Average } \\
\hline & & 01606500 & 01608500 & 01611500 & 01636500 & 03051000 & 03053500 & 03061500 & 03066000 & 03069500 & 03070500 & 03182500 & 03183500 & 03186500 & 03198500 & 03214000 & \\
\hline \multirow[t]{4}{*}{1972} & Fall & 92 & 92 & 92 & 92 & 82 & 80 & 90 & 87 & 80 & 82 & 88 & 92 & 81 & 92 & 92 & 88 \\
\hline & Winter & 85 & 85 & 89 & 61 & 85 & 86 & 89 & 74 & 79 & 86 & 79 & 82 & 76 & 89 & 90 & 82 \\
\hline & Spring & 83 & 80 & 91 & 85 & 76 & 75 & 68 & 76 & 76 & 69 & 76 & 79 & 75 & 82 & 89 & 79 \\
\hline & Summer & 92 & 92 & 92 & 92 & 85 & 81 & 91 & 78 & 82 & 64 & 83 & 92 & 83 & 92 & 92 & 86 \\
\hline \multirow[t]{4}{*}{1973} & Fall & 92 & 92 & 92 & 92 & 92 & 92 & 78 & 89 & 90 & 63 & 92 & 92 & 92 & 92 & 92 & 89 \\
\hline & Winter & 90 & 90 & 90 & 90 & 66 & 71 & 78 & 66 & 71 & 75 & 80 & 75 & 73 & 73 & 74 & 77 \\
\hline & Spring & 81 & 83 & 88 & 91 & 83 & 72 & 84 & 87 & 83 & 84 & 85 & 91 & 84 & 86 & 90 & 85 \\
\hline & Summer & 90 & 92 & 92 & 92 & 87 & 73 & 92 & 81 & 72 & 82 & 74 & 87 & 89 & 90 & 89 & 85 \\
\hline \multirow[t]{4}{*}{1974} & Fall & 92 & 92 & 92 & 92 & 82 & 78 & 90 & 91 & 85 & 82 & 80 & 83 & 85 & 83 & 92 & 87 \\
\hline & Winter & 90 & 90 & 90 & 90 & 87 & 87 & 84 & 90 & 90 & 86 & 89 & 88 & 89 & 90 & 90 & 89 \\
\hline & Spring & 88 & 88 & 91 & 89 & 88 & 88 & 86 & 77 & 87 & 85 & 86 & 91 & 89 & 86 & 91 & 87 \\
\hline & Summer & 92 & 92 & 92 & 92 & 89 & 90 & 88 & 92 & 90 & 90 & 90 & 92 & 89 & 92 & 92 & 91 \\
\hline \multirow[t]{4}{*}{1975} & Fall & 77 & 77 & 60 & 76 & 77 & 74 & 92 & 67 & 67 & 85 & 77 & 77 & 75 & 92 & 92 & 78 \\
\hline & Winter & 90 & 90 & 88 & 87 & 81 & 80 & 90 & 86 & 84 & 87 & 86 & 87 & 80 & 81 & 86 & 86 \\
\hline & Spring & 78 & 80 & 83 & 80 & 82 & 86 & 88 & 76 & 80 & 85 & 80 & 82 & 81 & 86 & 89 & 82 \\
\hline & Summer & 92 & 92 & 92 & 92 & 81 & 75 & 86 & 83 & 88 & 82 & 82 & 90 & 78 & 88 & 92 & 86 \\
\hline \multirow[t]{4}{*}{1976} & Fall & 92 & 92 & 92 & 92 & 79 & 75 & 92 & 92 & 83 & 92 & 92 & 92 & 84 & 92 & 92 & 89 \\
\hline & Winter & 83 & 80 & 89 & 91 & 75 & 76 & 80 & 74 & 74 & 81 & 74 & 71 & 71 & 81 & 82 & 79 \\
\hline & Spring & 38 & 31 & 36 & 56 & 36 & 48 & 69 & 42 & 32 & 73 & 40 & 38 & 40 & 24 & 40 & 43 \\
\hline & Summer & 53 & 57 & 86 & 57 & 58 & 62 & 91 & 64 & 62 & 85 & 62 & 57 & 73 & 76 & 68 & 67 \\
\hline \multirow[t]{4}{*}{1977} & Fall & 92 & 92 & 92 & 92 & 92 & 92 & 92 & 92 & 92 & 92 & 92 & 92 & 92 & 92 & 92 & 92 \\
\hline & Winter & 38 & 35 & 40 & 26 & 47 & 45 & 48 & 43 & 42 & 47 & 46 & 40 & 45 & 41 & 43 & 42 \\
\hline & Spring & 31 & 26 & 33 & 30 & 51 & 47 & 64 & 45 & 48 & 59 & 37 & 30 & 59 & 48 & 70 & 45 \\
\hline & Summer & 22 & 21 & 30 & 3 & 91 & 92 & 92 & 82 & 89 & 91 & 92 & 90 & 92 & 90 & 92 & 71 \\
\hline \multirow[t]{4}{*}{1978} & Fall & 87 & 84 & 87 & 68 & 92 & 92 & 92 & 92 & 91 & 92 & 92 & 92 & 92 & 92 & 92 & 89 \\
\hline & Winter & 47 & 48 & 83 & 90 & 44 & 43 & 55 & 32 & 34 & 40 & 44 & 45 & 41 & 65 & 80 & 53 \\
\hline & Spring & 72 & 69 & 82 & 84 & 82 & 81 & 78 & 83 & 79 & 82 & 76 & 69 & 72 & 74 & 76 & 77 \\
\hline & Summer & 88 & 92 & 92 & 92 & 87 & 90 & 92 & 90 & 81 & 92 & 75 & 71 & 70 & 89 & 92 & 86 \\
\hline 1979 & Fall & 42 & 43 & 92 & 64 & 50 & 53 & 87 & 49 & 45 & 74 & 40 & 35 & 40 & 48 & 78 & 56 \\
\hline & Winter & 75 & 82 & 79 & 90 & 69 & 70 & 79 & 73 & 73 & 69 & 73 & 75 & 74 & 78 & 84 & 76 \\
\hline & Spring & 85 & 87 & 82 & 91 & 75 & 74 & 79 & 78 & 77 & 72 & 87 & 91 & 91 & 91 & 91 & 83 \\
\hline & Summer & 92 & 92 & 92 & 92 & 92 & 92 & 92 & 92 & 92 & 91 & 92 & 92 & 92 & 92 & 92 & 92 \\
\hline 1980 & Fall & 92 & 92 & 92 & 92 & 92 & 92 & 92 & 92 & 92 & 92 & 92 & 92 & 92 & 92 & 92 & 92 \\
\hline & Winter & 68 & 75 & 79 & 91 & 59 & 58 & 57 & 54 & 54 & 47 & 61 & 63 & 62 & 73 & 81 & 65 \\
\hline & Spring & 80 & 81 & 80 & 78 & 82 & 83 & 86 & 86 & 81 & 84 & 74 & 74 & 77 & 67 & 66 & 79 \\
\hline & Summer & 86 & 86 & 92 & 69 & 92 & 91 & 92 & 92 & 87 & 92 & 84 & 88 & 87 & 92 & 92 & 88 \\
\hline 1981 & Fall & 55 & 68 & 66 & 32 & 67 & 67 & 70 & 56 & 59 & 67 & 44 & 44 & 66 & 85 & 92 & 63 \\
\hline & Winter & 32 & 27 & 25 & 14 & 62 & 58 & 64 & 51 & 51 & 64 & 40 & 37 & 42 & 58 & 51 & 45 \\
\hline & Spring & 85 & 87 & 85 & 35 & 91 & 90 & 91 & 91 & 91 & 91 & 88 & 85 & 84 & 86 & 91 & 85 \\
\hline & Summer & 70 & 73 & 72 & 54 & 83 & 81 & 92 & 83 & 82 & 85 & 72 & 73 & 79 & 73 & 92 & 78 \\
\hline 1982 & Fall & 66 & 66 & 67 & 29 & 73 & 77 & 72 & 84 & 77 & 70 & 67 & 66 & 78 & 61 & 88 & 69 \\
\hline & Winter & 70 & 70 & 67 & 67 & 77 & 74 & 66 & 80 & 83 & 78 & 80 & 82 & 82 & 73 & 73 & 75 \\
\hline & Spring & 73 & 73 & 69 & 80 & 62 & 57 & 57 & 66 & 64 & 50 & 67 & 75 & 70 & 76 & 78 & 68 \\
\hline & Summer & 77 & 75 & 63 & 82 & 92 & 92 & 92 & 91 & 89 & 84 & 80 & 76 & 82 & 92 & 92 & 84 \\
\hline 1983 & Fall & 88 & 86 & 63 & 77 & 90 & 84 & 80 & 87 & 88 & 63 & 86 & 86 & 83 & 92 & 92 & 83 \\
\hline & Winter & 63 & 57 & 51 & 57 & 55 & 53 & 55 & 55 & 58 & 58 & 66 & 69 & 56 & 59 & 68 & 59 \\
\hline & Spring & 77 & 78 & 78 & 91 & 81 & 76 & 74 & 73 & 77 & 85 & 82 & 83 & 82 & 85 & 78 & 80 \\
\hline & Summer & 32 & 35 & 43 & 58 & 62 & 66 & 70 & 21 & 33 & 78 & 40 & 42 & 43 & 66 & 72 & 51 \\
\hline 1984 & Fall & 74 & 79 & 85 & 84 & 72 & 70 & 77 & 72 & 74 & 73 & 74 & 71 & 73 & 79 & 86 & 76 \\
\hline & Winter & 71 & 80 & 86 & 91 & 65 & 59 & 69 & 68 & 60 & 65 & 70 & 71 & 56 & 68 & 60 & 69 \\
\hline & Spring & 63 & 60 & 64 & 71 & 55 & 58 & 69 & 62 & 53 & 69 & 58 & 58 & 55 & 64 & 71 & 62 \\
\hline & Summer & 87 & 92 & 82 & 92 & 86 & 89 & 92 & 79 & 82 & 92 & 92 & 92 & 88 & 87 & 75 & 87 \\
\hline 1985 & Fall & 92 & 92 & 86 & 91 & 83 & 86 & 83 & 74 & 78 & 78 & 92 & 92 & 85 & 89 & 86 & 86 \\
\hline & Winter & 59 & 76 & 61 & 73 & 66 & 69 & 70 & 67 & 70 & 58 & 68 & 74 & 55 & 78 & 74 & 68 \\
\hline & Spring & 79 & 74 & 63 & 48 & 77 & 82 & 71 & 79 & 79 & 86 & 73 & 73 & 70 & 84 & 74 & 74 \\
\hline & Summer & 73 & 73 & 70 & 49 & 69 & 63 & 64 & 71 & 71 & 80 & 74 & 75 & 65 & 64 & 75 & 69 \\
\hline
\end{tabular}


Table 6. Number of days exceeding the relevant seasonal 75-percent flow duration at 15 selected streamgages in West Virginia, by season, water years 1930-2011, and their average as a proportion.-Continued

[Average is for full years only. NO, not operated during that season; PR, operated for part of the season; fall, October 1-December 31; winter, January 1March 31; spring, April 1-June 30; summer, July 1-September 30. Flow duration values from Wiley, 2006]

\begin{tabular}{|c|c|c|c|c|c|c|c|c|c|c|c|c|c|c|c|c|c|}
\hline \multirow{2}{*}{$\begin{array}{c}\text { Water } \\
\text { year }\end{array}$} & \multirow{2}{*}{ Season } & \multicolumn{15}{|c|}{ Streamgage } & \multirow{2}{*}{ Average } \\
\hline & & 01606500 & 01608500 & 01611500 & 01636500 & 03051000 & 03053500 & 03061500 & 03066000 & 03069500 & 03070500 & 03182500 & 03183500 & 03186500 & 03198500 & 03214000 & \\
\hline \multirow[t]{4}{*}{1986} & Fall & 76 & 72 & 71 & 71 & 72 & 71 & 64 & 76 & 74 & 67 & 72 & 70 & 69 & 66 & 81 & 71 \\
\hline & Winter & 62 & 71 & 68 & 63 & 49 & 62 & 65 & 56 & 53 & 59 & 51 & 58 & 45 & 63 & 59 & 59 \\
\hline & Spring & 46 & 59 & 48 & 42 & 58 & 50 & 49 & 61 & 59 & 44 & 55 & 48 & 64 & 74 & 64 & 55 \\
\hline & Summer & 83 & 76 & 55 & 19 & 86 & 92 & 72 & 80 & 89 & 77 & 83 & 80 & 92 & 92 & 92 & 78 \\
\hline \multirow[t]{4}{*}{1987} & Fall & 79 & 62 & 57 & 48 & 92 & 92 & 92 & 86 & 92 & 92 & 84 & 81 & 92 & 92 & 92 & 82 \\
\hline & Winter & 77 & 76 & 79 & 76 & 48 & 52 & 38 & 68 & 58 & 42 & 74 & 76 & 61 & 59 & 70 & 64 \\
\hline & Spring & 72 & 70 & 68 & 78 & 71 & 61 & 72 & 72 & 73 & 68 & 70 & 70 & 78 & 76 & 85 & 72 \\
\hline & Summer & 62 & 54 & 32 & 55 & 53 & 54 & 88 & 47 & 48 & 71 & 47 & 45 & 53 & 53 & 66 & 55 \\
\hline \multirow[t]{4}{*}{1988} & Fall & 88 & 89 & 67 & 92 & 69 & 69 & 58 & 74 & 75 & 70 & 70 & 63 & 70 & 67 & 41 & 71 \\
\hline & Winter & 55 & 53 & 58 & 69 & 61 & 64 & 67 & 60 & 58 & 71 & 57 & 52 & 57 & 30 & 11 & 55 \\
\hline & Spring & 67 & 65 & 74 & 58 & 63 & 62 & 59 & 64 & 65 & 63 & 58 & 58 & 61 & 60 & 47 & 62 \\
\hline & Summer & 35 & 60 & 88 & 32 & 38 & 36 & 47 & 35 & 40 & 52 & 24 & 27 & 31 & 47 & 36 & 42 \\
\hline \multirow[t]{4}{*}{1989} & Fall & 61 & 57 & 35 & 14 & 73 & 71 & 76 & 77 & 74 & 81 & 64 & 68 & 71 & 70 & 74 & 64 \\
\hline & Winter & 59 & 54 & 49 & 29 & 72 & 70 & 84 & 76 & 78 & 82 & 70 & 77 & 70 & 72 & 72 & 68 \\
\hline & Spring & 89 & 84 & 80 & 82 & 90 & 91 & 89 & 91 & 91 & 86 & 84 & 81 & 89 & 91 & 91 & 87 \\
\hline & Summer & 92 & 92 & 92 & 92 & 92 & 92 & 92 & 92 & 92 & 92 & 92 & 92 & 92 & 92 & 92 & 92 \\
\hline \multirow[t]{4}{*}{1990} & Fall & 92 & 92 & 92 & 92 & 92 & 91 & 92 & 89 & 83 & 92 & 92 & 92 & 83 & 92 & 92 & 91 \\
\hline & Winter & 89 & 77 & 63 & 90 & 86 & 85 & 79 & 71 & 87 & 68 & 88 & 90 & 85 & 87 & 90 & 82 \\
\hline & Spring & 76 & 73 & 70 & 75 & 81 & 88 & 89 & 78 & 79 & 79 & 73 & 75 & 78 & 77 & 86 & 78 \\
\hline & Summer & 78 & 90 & 89 & 81 & 89 & 90 & 92 & 82 & 92 & 92 & 92 & 92 & 87 & 85 & 89 & 88 \\
\hline \multirow[t]{4}{*}{1991} & Fall & 82 & 82 & 81 & 83 & 86 & 89 & 92 & 84 & 86 & 92 & 82 & 83 & 86 & 85 & 91 & 86 \\
\hline & Winter & 85 & 90 & 90 & 90 & 86 & 88 & 90 & 83 & 86 & 89 & 84 & 89 & 86 & 90 & 90 & 88 \\
\hline & Spring & 42 & 46 & 47 & 57 & 43 & 42 & 48 & 44 & 44 & 49 & 48 & 55 & 46 & 53 & 76 & 49 \\
\hline & Summer & 49 & 56 & 53 & 68 & 63 & 58 & 19 & 47 & 75 & 19 & 68 & 41 & 58 & 66 & 86 & 55 \\
\hline \multirow[t]{4}{*}{1992} & Fall & 38 & 37 & 46 & 31 & 50 & 55 & 41 & 40 & 46 & 40 & 43 & 40 & 51 & 55 & 55 & 45 \\
\hline & Winter & 65 & 58 & 51 & 50 & 82 & 76 & 74 & 84 & 79 & 75 & 63 & 66 & 76 & 69 & 62 & 69 \\
\hline & Spring & 84 & 86 & 77 & 81 & 70 & 71 & 48 & 69 & 68 & 61 & 84 & 88 & 82 & 85 & 90 & 76 \\
\hline & Summer & 91 & 79 & 92 & 87 & 91 & 92 & 92 & 90 & 85 & 92 & 91 & 84 & 88 & 92 & 92 & 89 \\
\hline 1993 & Fall & 56 & 51 & 71 & 80 & 53 & 58 & 65 & 53 & 52 & 65 & 59 & 55 & 59 & 92 & 81 & 63 \\
\hline & Winter & 65 & 71 & 78 & 90 & 63 & 66 & 72 & 53 & 57 & 69 & 63 & 67 & 66 & 61 & 54 & 66 \\
\hline & Spring & 60 & 60 & 62 & 81 & 54 & 53 & 55 & 59 & 55 & 51 & 59 & 64 & 62 & 80 & 77 & 62 \\
\hline & Summer & 25 & 29 & 84 & 92 & 23 & 26 & 52 & 33 & 27 & 50 & 27 & 22 & 27 & 87 & 78 & 45 \\
\hline 1994 & Fall & 77 & 69 & 71 & 91 & 86 & 89 & 92 & 85 & 86 & 92 & 87 & 85 & 76 & 92 & 90 & 85 \\
\hline & Winter & 89 & 86 & 89 & 90 & 78 & 79 & 88 & 77 & 74 & 77 & 81 & 87 & 78 & 89 & 90 & 83 \\
\hline & Spring & 61 & 61 & 59 & 73 & 63 & 70 & 61 & 64 & 63 & 63 & 53 & 53 & 68 & 67 & 73 & 63 \\
\hline & Summer & 91 & 92 & 92 & 92 & 88 & 90 & 92 & 92 & 90 & 92 & 76 & 81 & 83 & 92 & 92 & 89 \\
\hline 1995 & Fall & 48 & 58 & 79 & 92 & 45 & 29 & 67 & 51 & 50 & 61 & 43 & 43 & 44 & 91 & 92 & 60 \\
\hline & Winter & 71 & 72 & 79 & 81 & 70 & 73 & 72 & 68 & 70 & 60 & 67 & 70 & 66 & 81 & 76 & 72 \\
\hline & Spring & 76 & 70 & 66 & 65 & 75 & 73 & 86 & 74 & 72 & 71 & 77 & 82 & 66 & 91 & 91 & 76 \\
\hline & Summer & 72 & 77 & 62 & 89 & 37 & 36 & 68 & 65 & 45 & 29 & 46 & 49 & 31 & 71 & 82 & 57 \\
\hline 1996 & Fall & 80 & 82 & NO & 92 & 60 & 61 & 81 & 73 & 72 & 57 & 79 & 83 & 76 & 87 & 92 & 77 \\
\hline & Winter & 90 & 89 & NO & 91 & 77 & 80 & 79 & 86 & 82 & 77 & 81 & 81 & 82 & 89 & 83 & 83 \\
\hline & Spring & 91 & 91 & NO & 91 & 74 & 79 & 85 & 82 & 82 & 81 & 87 & 89 & 79 & 83 & 88 & 84 \\
\hline & Summer & 92 & 92 & NO & 92 & 92 & 92 & 92 & 92 & 92 & 92 & 92 & 92 & 87 & 92 & 92 & 92 \\
\hline 1997 & Fall & 92 & 92 & 92 & 92 & 92 & 92 & 92 & 92 & 92 & 92 & 92 & 92 & 92 & 92 & 92 & 92 \\
\hline & Winter & 80 & 80 & 86 & 90 & 71 & 71 & 85 & 72 & 70 & 73 & 75 & 79 & 66 & 89 & 90 & 78 \\
\hline & Spring & 78 & 82 & 77 & 91 & 73 & 86 & 87 & 80 & 76 & 79 & 76 & 77 & 72 & 91 & 91 & 81 \\
\hline & Summer & 86 & 68 & 92 & 92 & 59 & 60 & 89 & 81 & 66 & 74 & 57 & 52 & 60 & 92 & 91 & 75 \\
\hline 1998 & Fall & 91 & 76 & 78 & 89 & 65 & 63 & 66 & 75 & 73 & 69 & 67 & 69 & 67 & 73 & 70 & 73 \\
\hline & Winter & 88 & 90 & 90 & 90 & 88 & 88 & 86 & 85 & 89 & 88 & 89 & 86 & 87 & 85 & 69 & 87 \\
\hline & Spring & 72 & 91 & 87 & 91 & 72 & 72 & 74 & 79 & 75 & 77 & 69 & 81 & 72 & 89 & 91 & 79 \\
\hline & Summer & 71 & 68 & 83 & 92 & 81 & 79 & 77 & 70 & 69 & 75 & 76 & 55 & 51 & 74 & 85 & 74 \\
\hline 1999 & Fall & 10 & 10 & 68 & 46 & 49 & 33 & 16 & 14 & 30 & 33 & 29 & 23 & 26 & 55 & 76 & 35 \\
\hline & Winter & 62 & 62 & 40 & 58 & 72 & 75 & 65 & 77 & 77 & 80 & 68 & 66 & 81 & 73 & 60 & 68 \\
\hline & Spring & 44 & 46 & 40 & 31 & 48 & 47 & 51 & 48 & 48 & 51 & 52 & 56 & 49 & 41 & 57 & 47 \\
\hline & Summer & 23 & 31 & 40 & 26 & 0 & 10 & 31 & 16 & 15 & 40 & 16 & 18 & 19 & 39 & 52 & 25 \\
\hline
\end{tabular}


Table 6. Number of days exceeding the relevant seasonal 75-percent flow duration at 15 selected streamgages in West Virginia, by season, water years 1930-2011, and their average as a proportion.-Continued

[Average is for full years only. NO, not operated during that season; PR, operated for part of the season; fall, October 1-December 31; winter, January 1March 31; spring, April 1-June 30; summer, July 1-September 30. Flow duration values from Wiley, 2006]

\begin{tabular}{|c|c|c|c|c|c|c|c|c|c|c|c|c|c|c|c|c|c|}
\hline \multirow{2}{*}{$\begin{array}{c}\text { Water } \\
\text { year }\end{array}$} & \multirow{2}{*}{ Season } & \multicolumn{15}{|c|}{ Streamgage } & \multirow{2}{*}{ Average } \\
\hline & & 01606500 & 01608500 & 01611500 & 01636500 & 03051000 & 03053500 & 03061500 & 03066000 & 03069500 & 03070500 & 03182500 & 03183500 & 03186500 & 03198500 & 03214000 & \\
\hline \multirow[t]{4}{*}{2000} & Fall & 92 & 92 & 92 & 92 & 62 & 61 & 41 & 86 & 84 & 52 & 88 & 87 & 86 & 71 & 79 & 78 \\
\hline & Winter & 46 & 45 & 41 & 61 & 55 & 51 & 49 & 59 & 62 & 49 & 56 & 49 & 61 & 39 & 36 & 51 \\
\hline & Spring & 57 & 66 & 63 & 64 & 71 & 77 & 83 & 64 & 70 & 85 & 76 & 74 & 82 & 75 & 63 & 71 \\
\hline & Summer & 92 & 92 & 87 & 92 & 92 & 92 & 92 & 90 & 92 & 92 & 92 & 92 & 92 & 92 & 92 & 92 \\
\hline \multirow[t]{4}{*}{2001} & Fall & 68 & 79 & 75 & 79 & 71 & 75 & 92 & 76 & 68 & 61 & 82 & 81 & 65 & 92 & 90 & 77 \\
\hline & Winter & 67 & 70 & 67 & 30 & 66 & 61 & 72 & 72 & 65 & 66 & 60 & 59 & 60 & 54 & 48 & 61 \\
\hline & Spring & 63 & 69 & 66 & 73 & 69 & 67 & 63 & 65 & 66 & 68 & 59 & 61 & 68 & 68 & 80 & 67 \\
\hline & Summer & 87 & 90 & 92 & 68 & 76 & 86 & 92 & 86 & 76 & 87 & 77 & 86 & 65 & 92 & 92 & 83 \\
\hline \multirow[t]{4}{*}{2002} & Fall & 16 & 19 & 16 & 2 & 23 & 26 & 56 & 23 & 23 & 43 & 22 & 20 & 23 & 65 & 80 & 30 \\
\hline & Winter & 19 & 14 & 11 & 4 & 32 & 34 & 54 & 52 & 51 & 59 & 31 & 31 & 52 & 31 & 23 & 33 \\
\hline & Spring & 73 & 74 & 74 & 38 & 78 & 76 & 78 & 74 & 76 & 79 & 67 & 64 & 72 & 73 & 83 & 72 \\
\hline & Summer & 50 & 47 & 49 & 7 & 65 & 56 & 68 & 68 & 62 & 65 & 67 & 70 & 60 & 77 & 76 & 59 \\
\hline \multirow[t]{4}{*}{2003} & Fall & 87 & 90 & 88 & 85 & 85 & 82 & 81 & 85 & 86 & 77 & 89 & 87 & 84 & 91 & 91 & 86 \\
\hline & Winter & 73 & 60 & 66 & 80 & 64 & 63 & 55 & 69 & 63 & 61 & 64 & 67 & 65 & 71 & 70 & 66 \\
\hline & Spring & 91 & 91 & 91 & 91 & 88 & 90 & 91 & 90 & 89 & 86 & 90 & 91 & 89 & 91 & 91 & 90 \\
\hline & Summer & 92 & 92 & 92 & 92 & 92 & 92 & 92 & 92 & 92 & 92 & 92 & 92 & 92 & 92 & 92 & 92 \\
\hline \multirow[t]{4}{*}{2004} & Fall & 92 & 92 & 92 & 92 & 92 & 92 & 92 & 92 & 92 & 92 & 92 & 92 & 90 & 92 & 92 & 92 \\
\hline & Winter & 73 & 85 & 91 & 91 & 71 & 74 & 82 & 78 & 73 & 79 & 70 & 74 & 68 & 82 & 81 & 78 \\
\hline & Spring & 88 & 89 & 90 & 90 & 86 & 89 & 86 & 89 & 88 & 86 & 82 & 84 & 81 & 91 & 91 & 87 \\
\hline & Summer & 90 & 88 & 92 & 91 & 88 & 92 & 92 & 87 & 85 & 92 & 92 & 92 & 58 & 92 & 92 & 88 \\
\hline \multirow[t]{4}{*}{2005} & Fall & 92 & 92 & 92 & 92 & 87 & 88 & 92 & 92 & 88 & 87 & 92 & 92 & 92 & 92 & 92 & 91 \\
\hline & Winter & 80 & 78 & 90 & 90 & 79 & 85 & 89 & 69 & 71 & 76 & 72 & 75 & 74 & 89 & 90 & 80 \\
\hline & Spring & 73 & 74 & 75 & 77 & 65 & 66 & 69 & 69 & 66 & 75 & 66 & 63 & 59 & 74 & 72 & 70 \\
\hline & Summer & 77 & 78 & 83 & 74 & 64 & 51 & 83 & 61 & 66 & 55 & 73 & 73 & 69 & 92 & 92 & 73 \\
\hline \multirow[t]{4}{*}{2006} & Fall & 78 & 80 & 79 & 86 & 71 & 76 & 76 & 71 & 71 & 72 & 64 & 66 & 69 & 78 & 92 & 75 \\
\hline & Winter & 64 & 58 & 62 & 70 & 56 & 61 & 52 & 73 & 70 & 64 & 59 & 58 & 65 & 54 & 25 & 59 \\
\hline & Spring & 63 & 63 & 50 & 38 & 78 & 77 & 78 & 73 & 74 & 64 & 63 & 58 & 73 & 63 & 66 & 65 \\
\hline & Summer & 73 & 83 & 73 & 84 & 70 & 73 & 91 & 83 & 83 & 74 & 81 & 80 & 86 & 92 & 92 & 81 \\
\hline \multirow[t]{4}{*}{2007} & Fall & 92 & 92 & 87 & 92 & 92 & 92 & 92 & 91 & 92 & 86 & 92 & 92 & 92 & 92 & 92 & 91 \\
\hline & Winter & 65 & 63 & 58 & 90 & 79 & 76 & 81 & 77 & 70 & 72 & 63 & 66 & 67 & 77 & 58 & 71 \\
\hline & Spring & 72 & 69 & 53 & 68 & 56 & 54 & 52 & 59 & 62 & 51 & 75 & 71 & 68 & 57 & 67 & 62 \\
\hline & Summer & 58 & 71 & 78 & 78 & 79 & 73 & 92 & 90 & 82 & 83 & 71 & 60 & 79 & 69 & 79 & 76 \\
\hline \multirow[t]{4}{*}{2008} & Fall & 68 & 68 & 64 & 32 & 72 & 69 & 92 & 69 & 69 & 56 & 68 & 68 & 68 & 71 & 71 & 67 \\
\hline & Winter & 83 & 82 & 63 & 46 & 84 & 84 & 89 & 82 & 82 & 82 & 83 & 81 & 76 & 56 & 48 & 75 \\
\hline & Spring & 82 & 84 & 83 & 71 & 76 & 77 & 89 & 91 & 89 & 87 & 72 & 71 & 67 & 83 & 67 & 79 \\
\hline & Summer & 66 & 76 & 75 & 53 & 53 & 48 & 92 & 66 & 59 & 91 & 48 & 43 & 35 & 87 & 68 & 64 \\
\hline \multirow[t]{4}{*}{2009} & Fall & 45 & 47 & 80 & 52 & 43 & 40 & 52 & 52 & 44 & 45 & 44 & 39 & 46 & 61 & 59 & 50 \\
\hline & Winter & 49 & 37 & 26 & 13 & 59 & 52 & 56 & 73 & 66 & 58 & 48 & 51 & 64 & 69 & 62 & 52 \\
\hline & Spring & 83 & 85 & 89 & 89 & 73 & 78 & 81 & 81 & 74 & 89 & 82 & 85 & 78 & 87 & 91 & 83 \\
\hline & Summer & 66 & 67 & 62 & 50 & 68 & 82 & 85 & 65 & 63 & 78 & 82 & 84 & 72 & 92 & 92 & 74 \\
\hline \multirow[t]{4}{*}{2010} & Fall & 79 & 76 & 69 & 64 & 88 & 92 & 78 & 88 & 87 & 89 & 91 & 92 & 92 & 92 & 92 & 85 \\
\hline & Winter & 74 & 81 & 82 & 90 & 62 & 78 & 78 & 44 & 47 & 64 & 55 & 65 & 48 & 83 & 83 & 69 \\
\hline & Spring & 50 & 51 & 65 & 56 & 81 & 71 & 81 & 73 & 69 & 74 & 54 & 70 & 64 & 91 & 91 & 69 \\
\hline & Summer & 29 & 21 & 16 & 20 & 63 & 57 & 57 & 29 & 48 & 33 & 51 & 40 & 57 & 92 & 92 & 47 \\
\hline 2011 & Fall & 71 & 71 & 68 & 83 & 89 & 87 & 62 & 70 & 84 & 59 & 87 & 78 & 88 & 88 & 92 & 78 \\
\hline & Winter & 56 & 54 & 44 & 40 & 72 & 76 & 77 & 66 & 66 & 71 & 57 & 54 & 62 & 64 & 51 & 61 \\
\hline & Spring & 75 & 77 & 78 & 91 & 65 & 71 & 76 & 82 & 73 & 78 & 65 & 67 & 69 & 71 & 87 & 75 \\
\hline & Summer & 60 & 65 & 79 & 75 & 84 & 86 & 92 & 92 & 89 & 92 & 43 & 40 & 55 & 92 & 92 & 76 \\
\hline
\end{tabular}


Table 7. Maximum number of days between flows exceeding the annual 75-percent flow duration at 15 selected streamgages in West Virginia, water years 1930-2011.

[NO, not operated during that water year]

\begin{tabular}{|c|c|c|c|c|c|c|c|c|c|c|c|c|c|c|c|}
\hline \multirow{2}{*}{ Water year } & \multicolumn{15}{|c|}{ Streamgages } \\
\hline & 01606500 & 01608500 & 01611500 & 01636500 & 03051000 & 03053500 & 03061500 & 03066000 & 03069500 & 03070500 & 03182500 & 03183500 & 03186500 & 03198500 & 03214000 \\
\hline 1930 & 103 & 102 & 93 & 76 & 97 & 109 & NO & 69 & 97 & 43 & 103 & 105 & 63 & 125 & 88 \\
\hline 1931 & 171 & 192 & 162 & 112 & 164 & 178 & NO & 130 & 158 & 109 & 170 & 173 & 107 & 222 & 134 \\
\hline 1932 & 73 & 73 & 78 & 98 & 42 & 40 & 41 & 32 & 40 & 41 & 56 & 58 & 27 & 60 & 64 \\
\hline 1933 & 79 & 80 & 84 & 28 & 45 & 58 & 74 & 12 & 45 & 73 & 46 & 64 & 32 & 38 & 96 \\
\hline 1934 & 62 & 52 & 37 & 47 & 28 & 37 & 45 & 21 & 21 & 44 & 70 & 71 & 30 & 64 & 82 \\
\hline 1935 & 21 & 27 & 46 & 15 & 23 & 23 & 29 & 20 & 22 & 27 & 20 & 17 & 17 & 22 & 21 \\
\hline 1936 & 46 & 47 & 53 & 11 & 39 & 39 & 41 & 27 & 48 & 26 & 35 & 33 & 75 & 51 & 51 \\
\hline 1937 & 62 & 63 & 69 & 15 & 50 & 49 & 57 & 43 & 64 & 29 & 36 & 41 & 45 & 38 & 40 \\
\hline 1938 & 25 & 26 & 48 & 10 & 32 & 37 & 64 & 24 & 31 & 18 & 26 & 24 & 25 & 34 & 19 \\
\hline 1939 & 42 & 44 & 111 & 47 & 43 & 54 & 113 & 42 & 42 & 51 & 43 & 46 & 41 & 60 & 39 \\
\hline 1940 & 28 & 36 & 34 & 24 & 69 & 81 & 69 & 21 & 23 & 77 & 31 & 113 & 68 & 167 & 169 \\
\hline 1941 & 18 & 25 & 18 & 22 & 32 & 29 & 30 & 15 & 24 & 29 & 31 & 33 & 35 & 78 & 78 \\
\hline 1942 & 56 & 93 & 102 & 97 & 46 & 48 & 31 & 17 & 29 & 25 & 52 & 51 & 32 & 79 & 82 \\
\hline 1943 & 25 & 43 & 62 & 33 & 21 & 20 & 21 & 26 & 24 & 34 & 24 & 23 & 23 & 79 & 72 \\
\hline 1944 & 65 & 84 & 82 & 121 & 54 & 68 & 37 & 59 & 57 & 59 & 67 & 90 & 97 & 113 & 161 \\
\hline 1945 & 13 & 22 & 26 & 8 & 12 & 11 & 22 & 13 & 12 & 20 & 23 & 110 & 110 & 62 & 102 \\
\hline 1946 & 58 & 52 & 49 & 48 & 58 & 79 & 37 & 53 & 69 & 70 & 60 & 65 & 44 & 81 & 60 \\
\hline 1947 & 83 & 77 & 47 & 55 & 83 & 104 & 62 & 78 & 94 & 95 & 85 & 92 & 69 & 107 & 133 \\
\hline 1948 & 47 & 53 & 55 & 52 & 54 & 46 & 31 & 46 & 40 & 36 & 26 & 23 & 48 & 51 & 30 \\
\hline 1949 & 3 & 6 & 9 & 0 & 17 & 19 & 23 & 17 & 13 & 42 & 20 & 20 & 19 & 48 & 54 \\
\hline 1950 & 33 & 25 & 33 & 20 & 11 & 23 & 39 & 28 & 13 & 72 & 23 & 22 & 5 & 12 & 11 \\
\hline 1951 & 20 & 27 & 35 & 28 & 42 & 42 & 62 & 41 & 33 & 67 & 61 & 59 & 15 & 37 & 13 \\
\hline 1952 & 45 & 44 & 43 & 61 & 52 & 53 & 109 & 56 & 53 & 113 & 92 & 91 & 46 & 44 & 33 \\
\hline 1953 & 76 & 76 & 49 & 25 & 89 & 102 & 54 & 89 & 89 & 120 & 87 & 81 & 89 & 67 & 60 \\
\hline 1954 & 119 & 120 & 102 & 50 & 117 & 114 & 128 & 102 & 102 & 194 & 149 & 149 & 146 & 139 & 99 \\
\hline 1955 & 41 & 41 & 41 & 44 & 37 & 36 & 35 & 32 & 34 & 30 & 25 & 35 & 46 & 50 & 38 \\
\hline 1956 & 63 & 57 & 62 & 54 & 80 & 51 & 43 & 45 & 48 & 12 & 69 & 82 & 57 & 98 & 89 \\
\hline 1957 & 62 & 85 & 89 & 87 & 62 & 80 & 99 & 63 & 63 & 92 & 32 & 31 & 32 & 63 & 26 \\
\hline 1958 & 68 & 91 & 95 & 93 & 68 & 86 & 30 & 68 & 69 & 98 & 12 & 12 & 19 & 21 & 21 \\
\hline 1959 & 67 & 121 & 52 & 54 & 53 & 28 & 29 & 46 & 33 & 75 & 52 & 50 & 43 & 55 & 36 \\
\hline 1960 & 26 & 33 & 15 & 11 & 76 & 51 & 52 & 18 & 15 & 44 & 25 & 52 & 17 & 78 & 31 \\
\hline 1961 & 42 & 42 & 92 & 96 & 30 & 24 & 33 & 14 & 31 & 39 & 19 & 38 & 24 & 33 & 32 \\
\hline 1962 & 67 & 69 & 57 & 48 & 71 & 64 & 71 & 63 & 63 & 85 & 73 & 54 & 43 & 38 & 35 \\
\hline 1963 & 72 & 100 & 86 & 97 & 22 & 15 & 39 & 15 & 16 & 44 & 81 & 65 & 23 & 43 & 32 \\
\hline 1964 & 75 & 120 & 124 & 134 & 59 & 52 & 82 & 53 & 53 & 63 & 91 & 91 & 59 & 77 & 83 \\
\hline 1965 & 66 & 66 & 43 & 80 & 62 & 74 & 50 & 79 & 62 & 46 & 60 & 60 & 40 & 30 & 30 \\
\hline 1966 & 82 & 92 & 130 & 198 & 36 & 123 & 69 & 86 & 39 & 64 & 40 & 57 & 32 & 83 & 87 \\
\hline 1967 & 27 & 24 & 10 & 17 & 26 & 31 & 54 & 25 & 25 & 29 & 24 & 24 & 27 & 26 & 27 \\
\hline 1968 & 77 & 92 & 66 & 19 & 30 & 30 & 26 & 27 & 30 & 37 & 93 & 41 & 37 & 16 & 18 \\
\hline 1969 & 96 & 112 & 38 & 35 & 36 & 35 & 62 & 35 & 24 & 40 & 111 & 60 & 23 & 14 & 35 \\
\hline 1970 & 34 & 32 & 53 & 33 & 17 & 18 & 74 & 19 & 15 & 71 & 36 & 35 & 25 & 43 & 55 \\
\hline 1971 & 50 & 54 & 57 & 57 & 21 & 24 & 16 & 29 & 19 & 16 & 55 & 56 & 21 & 30 & 20 \\
\hline 1972 & 22 & 23 & 13 & 0 & 23 & 35 & 32 & 30 & 14 & 41 & 32 & 29 & 27 & 11 & 0 \\
\hline 1973 & 17 & 25 & 1 & 5 & 18 & 30 & 37 & 21 & 23 & 47 & 38 & 20 & 17 & 17 & 15 \\
\hline 1974 & 12 & 12 & 13 & 17 & 35 & 20 & 15 & 15 & 16 & 12 & 16 & 14 & 22 & 21 & 16 \\
\hline 1975 & 27 & 28 & 27 & 27 & 26 & 18 & 14 & 23 & 25 & 19 & 30 & 27 & 30 & 22 & 16 \\
\hline 1976 & 52 & 37 & 28 & 45 & 56 & 50 & 38 & 61 & 56 & 38 & 55 & 51 & 31 & 22 & 12 \\
\hline 1977 & 89 & 91 & 73 & 132 & 14 & 21 & 7 & 24 & 26 & 16 & 14 & 16 & 20 & 13 & 3 \\
\hline 1978 & 26 & 17 & 15 & 159 & 26 & 13 & 4 & 20 & 20 & 7 & 27 & 26 & 28 & 16 & 16 \\
\hline 1979 & 83 & 64 & 17 & 64 & 52 & 39 & 17 & 37 & 39 & 21 & 82 & 84 & 76 & 73 & 63 \\
\hline
\end{tabular}


Table 7. Maximum number of days between flows exceeding the annual 75-percent flow duration at 15 selected streamgages in West Virginia, water years 1930-2011.-Continued

$[\mathrm{NO}$, not operated during that water year $]$

\begin{tabular}{|c|c|c|c|c|c|c|c|c|c|c|c|c|c|c|c|}
\hline \multirow{2}{*}{ Water year } & \multicolumn{15}{|c|}{ Streamgages } \\
\hline & 01606500 & 01608500 & 01611500 & 01636500 & 03051000 & 03053500 & 03061500 & 03066000 & 03069500 & 03070500 & 03182500 & 03183500 & 03186500 & 03198500 & 03214000 \\
\hline 1980 & 31 & 30 & 33 & 37 & 9 & 16 & 1 & 17 & 8 & 17 & 33 & 17 & 23 & 8 & 5 \\
\hline 1981 & 56 & 55 & 58 & 63 & 27 & 29 & 25 & 29 & 27 & 30 & 59 & 59 & 26 & 22 & 21 \\
\hline 1982 & 36 & 43 & 48 & 47 & 31 & 14 & 35 & 9 & 15 & 31 & 46 & 44 & 20 & 38 & 46 \\
\hline 1983 & 67 & 84 & 76 & 52 & 28 & 29 & 66 & 49 & 65 & 33 & 64 & 62 & 49 & 30 & 31 \\
\hline 1984 & 87 & 104 & 54 & 65 & 48 & 50 & 80 & 62 & 78 & 36 & 84 & 83 & 62 & 41 & 43 \\
\hline 1985 & 31 & 29 & 30 & 34 & 51 & 51 & 64 & 29 & 33 & 14 & 21 & 30 & 35 & 34 & 46 \\
\hline 1986 & 50 & 49 & 51 & 107 & 70 & 70 & 79 & 43 & 48 & 32 & 41 & 52 & 55 & 68 & 34 \\
\hline 1987 & 47 & 58 & 73 & 149 & 47 & 39 & 37 & 50 & 54 & 37 & 61 & 60 & 37 & 43 & 37 \\
\hline 1988 & 74 & 43 & 34 & 64 & 40 & 40 & 39 & 38 & 38 & 39 & 43 & 60 & 31 & 56 & 57 \\
\hline 1989 & 38 & 38 & 61 & 118 & 21 & 21 & 13 & 13 & 16 & 13 & 25 & 23 & 17 & 23 & 23 \\
\hline 1990 & 28 & 26 & 13 & 11 & 21 & 19 & 10 & 17 & 23 & 7 & 12 & 13 & 15 & 25 & 10 \\
\hline 1991 & 48 & 48 & 40 & 39 & 35 & 39 & 86 & 32 & 32 & 99 & 51 & 53 & 29 & 24 & 16 \\
\hline 1992 & 101 & 102 & 33 & 102 & 33 & 27 & 138 & 76 & 34 & 151 & 60 & 60 & 25 & 48 & 51 \\
\hline 1993 & 52 & 102 & 29 & 20 & 102 & 58 & 58 & 62 & 80 & 31 & 93 & 77 & 52 & 31 & 44 \\
\hline 1994 & 29 & 29 & 29 & 28 & 18 & 19 & 11 & 13 & 19 & 17 & 27 & 24 & 22 & 10 & 11 \\
\hline 1995 & 70 & 70 & 42 & 46 & 52 & 84 & 41 & 43 & 52 & 47 & 79 & 77 & 54 & 59 & 32 \\
\hline 1996 & 46 & 47 & NO & 5 & 79 & 67 & 11 & 12 & 49 & 61 & 58 & 79 & 17 & 10 & 15 \\
\hline 1997 & 21 & 20 & 22 & 15 & 33 & 29 & 14 & 20 & 20 & 45 & 35 & 35 & 19 & 18 & 33 \\
\hline 1998 & 22 & 22 & 37 & 35 & 29 & 29 & 72 & 30 & 20 & 32 & 25 & 62 & 24 & 44 & 59 \\
\hline 1999 & 116 & 116 & 95 & 94 & 118 & 119 & 117 & 59 & 93 & 44 & 82 & 109 & 98 & 41 & 74 \\
\hline 2000 & 18 & 8 & 11 & 7 & 122 & 123 & 149 & 25 & 10 & 32 & 25 & 13 & 8 & 44 & 40 \\
\hline 2001 & 31 & 29 & 29 & 39 & 21 & 20 & 13 & 23 & 21 & 18 & 28 & 27 & 47 & 26 & 30 \\
\hline 2002 & 98 & 97 & 56 & 204 & 72 & 58 & 37 & 60 & 73 & 31 & 99 & 97 & 116 & 66 & 71 \\
\hline 2003 & 9 & 8 & 8 & 12 & 8 & 11 & 11 & 8 & 8 & 11 & 13 & 9 & 11 & 11 & 11 \\
\hline 2004 & 24 & 18 & 12 & 16 & 16 & 6 & 3 & 16 & 8 & 9 & 20 & 29 & 58 & 0 & 0 \\
\hline 2005 & 27 & 25 & 44 & 25 & 31 & 27 & 65 & 28 & 28 & 28 & 28 & 26 & 27 & 19 & 12 \\
\hline 2006 & 35 & 34 & 52 & 32 & 52 & 35 & 71 & 49 & 49 & 50 & 55 & 35 & 34 & 44 & 18 \\
\hline 2007 & 53 & 36 & 33 & 30 & 21 & 18 & 15 & 13 & 13 & 21 & 18 & 24 & 17 & 40 & 33 \\
\hline 2008 & 41 & 61 & 58 & 56 & 43 & 45 & 23 & 36 & 54 & 25 & 57 & 74 & 58 & 38 & 42 \\
\hline 2009 & 45 & 44 & 36 & 79 & 89 & 100 & 42 & 34 & 98 & 60 & 101 & 131 & 101 & 61 & 64 \\
\hline 2010 & 53 & 77 & 76 & 110 & 34 & 34 & 51 & 53 & 27 & 52 & 40 & 52 & 30 & 11 & 14 \\
\hline 2011 & 55 & 54 & 49 & 30 & 14 & 10 & 21 & 14 & 11 & 18 & 60 & 59 & 58 & 26 & 26 \\
\hline \multicolumn{16}{|c|}{ Annual summary, water years 1930-2011: } \\
\hline Maximum & 171 & 192 & 162 & 204 & 164 & 178 & 149 & 130 & 158 & 194 & 170 & 173 & 146 & 222 & 169 \\
\hline 25 th percentile & 68 & 79 & 66 & 78 & 58 & 58 & 64 & 52 & 54 & 60 & 66 & 70 & 54 & 62 & 60 \\
\hline Median & 48 & 48 & 48 & 46 & 38 & 38 & 39 & 30 & 33 & 38 & 43 & 52 & 32 & 41 & 35 \\
\hline 75th percentile & 28 & 29 & 30 & 23 & 26 & 23 & 23 & 20 & 20 & 25 & 26 & 27 & 23 & 22 & 19 \\
\hline Minimum & 3 & 6 & 1 & 0 & 8 & 6 & 1 & 8 & 8 & 7 & 12 & 9 & 5 & 0 & 0 \\
\hline
\end{tabular}


Table 8. Maximum number of days between flows exceeding the seasonal 75-percent flow duration at 15 selected streamgages in West Virginia, water years, 1930-2011.

$[\mathrm{NO}$, not operated during that water year]

\begin{tabular}{|c|c|c|c|c|c|c|c|c|c|c|c|c|c|c|c|}
\hline \multirow{2}{*}{ Water year } & \multicolumn{15}{|c|}{ Streamgages } \\
\hline & 01606500 & 01608500 & 01611500 & 01636500 & 03051000 & 03053500 & 03061500 & 03066000 & 03069500 & 03070500 & 03182500 & 03183500 & 03186500 & 03198500 & 03214000 \\
\hline 1930 & 110 & 90 & 74 & 48 & 68 & 63 & NO & 45 & 69 & 39 & 75 & 109 & 33 & 66 & 91 \\
\hline 1931 & 177 & 159 & 77 & 105 & 135 & 132 & NO & 106 & 130 & 105 & 141 & 177 & 94 & 134 & 88 \\
\hline 1933 & 31 & 46 & 76 & 26 & 42 & 52 & 70 & 13 & 16 & 63 & 14 & 30 & 12 & 31 & 65 \\
\hline 1934 & 45 & 46 & 50 & 62 & 20 & 19 & 36 & 28 & 28 & 36 & 47 & 47 & 28 & 44 & 81 \\
\hline 1935 & 15 & 17 & 25 & 9 & 22 & 22 & 28 & 19 & 21 & 23 & 18 & 11 & 16 & 18 & 19 \\
\hline 1938 & 14 & 15 & 27 & 15 & 14 & 26 & 52 & 12 & 10 & 14 & 13 & 12 & 15 & 19 & 21 \\
\hline 1939 & 30 & 21 & 43 & 30 & 38 & 42 & 101 & 31 & 36 & 36 & 36 & 34 & 33 & 41 & 30 \\
\hline 1940 & 25 & 39 & 21 & 21 & 50 & 48 & 43 & 20 & 23 & 26 & 24 & 35 & 51 & 174 & 108 \\
\hline 1941 & 31 & 29 & 33 & 32 & 27 & 28 & 29 & 22 & 21 & 26 & 20 & 21 & 32 & 33 & 40 \\
\hline 1942 & 44 & 45 & 79 & 86 & 40 & 40 & 24 & 21 & 22 & 13 & 43 & 44 & 26 & 48 & 49 \\
\hline 1947 & 67 & 63 & 37 & 34 & 64 & 65 & 59 & 64 & 66 & 90 & 65 & 78 & 66 & 68 & 54 \\
\hline 1948 & 40 & 44 & 47 & 42 & 40 & 39 & 25 & 40 & 32 & 29 & 29 & 28 & 35 & 32 & 21 \\
\hline 1949 & 14 & 15 & 15 & 12 & 27 & 26 & 27 & 18 & 15 & 17 & 15 & 16 & 18 & 22 & 34 \\
\hline 1950 & 9 & 6 & 14 & 15 & 10 & 7 & 29 & 14 & 13 & 33 & 6 & 7 & 0 & 8 & 8 \\
\hline 1951 & 7 & 4 & 7 & 9 & 14 & 13 & 29 & 21 & 19 & 21 & 11 & 11 & 11 & 15 & 14 \\
\hline 1952 & 22 & 21 & 38 & 32 & 23 & 43 & 76 & 52 & 50 & 58 & 42 & 42 & 42 & 37 & 21 \\
\hline 1953 & 38 & 37 & 27 & 16 & 61 & 60 & 46 & 87 & 86 & 129 & 54 & 52 & 59 & 54 & 38 \\
\hline 1954 & 77 & 74 & 41 & 44 & 111 & 110 & 81 & 98 & 98 & 203 & 107 & 80 & 116 & 93 & 93 \\
\hline 1955 & 16 & 19 & 21 & 44 & 33 & 32 & 24 & 19 & 19 & 19 & 21 & 21 & 34 & 37 & 35 \\
\hline 1956 & 29 & 30 & 48 & 64 & 47 & 47 & 28 & 28 & 28 & 28 & 36 & 67 & 53 & 82 & 45 \\
\hline 1957 & 40 & 49 & 69 & 62 & 61 & 61 & 51 & 48 & 56 & 39 & 24 & 23 & 15 & 50 & 25 \\
\hline 1958 & 16 & 32 & 18 & 17 & 67 & 67 & 20 & 21 & 62 & 12 & 15 & 17 & 15 & 18 & 13 \\
\hline 1966 & 51 & 61 & 166 & 123 & 29 & 49 & 76 & 45 & 29 & 46 & 29 & 34 & 28 & 119 & 69 \\
\hline 1967 & 21 & 16 & 11 & 28 & 15 & 26 & 36 & 10 & 23 & 29 & 15 & 10 & 22 & 22 & 10 \\
\hline 1968 & 49 & 54 & 19 & 23 & 29 & 27 & 32 & 27 & 28 & 28 & 45 & 27 & 29 & 29 & 30 \\
\hline 1969 & 68 & 74 & 59 & 46 & 31 & 32 & 39 & 34 & 33 & 37 & 63 & 37 & 36 & 19 & 27 \\
\hline 1970 & 35 & 21 & 26 & 23 & 15 & 16 & 28 & 20 & 27 & 33 & 38 & 24 & 17 & 40 & 53 \\
\hline 1971 & 21 & 22 & 21 & 39 & 17 & 19 & 15 & 10 & 18 & 10 & 20 & 46 & 20 & 20 & 7 \\
\hline 1972 & 8 & 11 & 2 & 20 & 12 & 12 & 16 & 15 & 12 & 21 & 13 & 12 & 12 & 9 & 1 \\
\hline 1973 & 7 & 6 & 2 & 0 & 10 & 12 & 11 & 10 & 11 & 23 & 7 & 11 & 10 & 17 & 16 \\
\hline 1974 & 3 & 3 & 0 & 1 & 10 & 11 & 5 & 5 & 7 & 10 & 12 & 9 & 7 & 9 & 0 \\
\hline 1975 & 15 & 15 & 17 & 11 & 15 & 15 & 6 & 15 & 15 & 8 & 16 & 15 & 16 & 9 & 4 \\
\hline 1976 & 31 & 31 & 28 & 26 & 27 & 25 & 12 & 15 & 28 & 9 & 30 & 32 & 17 & 39 & 28 \\
\hline 1977 & 48 & 65 & 58 & 143 & 43 & 43 & 42 & 42 & 42 & 42 & 46 & 48 & 42 & 42 & 28 \\
\hline 1978 & 28 & 22 & 7 & 19 & 36 & 37 & 31 & 41 & 39 & 35 & 34 & 33 & 32 & 17 & 15 \\
\hline 1979 & 51 & 46 & 11 & 23 & 30 & 28 & 12 & 28 & 32 & 19 & 60 & 75 & 60 & 30 & 6 \\
\hline
\end{tabular}


Table 8. Maximum number of days between flows exceeding the seasonal 75-percent flow duration at 15 selected streamgages in West Virginia, water years, 1930-2011.-Continued

$[\mathrm{NO}$, not operated during that water year]

\begin{tabular}{|c|c|c|c|c|c|c|c|c|c|c|c|c|c|c|c|}
\hline \multirow{2}{*}{ Water year } & \multicolumn{15}{|c|}{ Streamgages } \\
\hline & 01606500 & 01608500 & 01611500 & 01636500 & 03051000 & 03053500 & 03061500 & 03066000 & 03069500 & 03070500 & 03182500 & 03183500 & 03186500 & 03198500 & 03214000 \\
\hline 1980 & 14 & 14 & 9 & 18 & 18 & 18 & 22 & 25 & 21 & 29 & 20 & 16 & 17 & 18 & 25 \\
\hline 1981 & 32 & 34 & 42 & 45 & 25 & 26 & 22 & 25 & 26 & 25 & 33 & 33 & 26 & 24 & 32 \\
\hline 1982 & 29 & 26 & 29 & 35 & 19 & 24 & 20 & 20 & 20 & 32 & 33 & 31 & 14 & 14 & 12 \\
\hline 1983 & 47 & 45 & 34 & 33 & 21 & 24 & 22 & 21 & 20 & 19 & 45 & 44 & 45 & 22 & 19 \\
\hline 1984 & 60 & 58 & 28 & 20 & 33 & 45 & 22 & 29 & 31 & 25 & 59 & 65 & 58 & 22 & 16 \\
\hline 1985 & 19 & 19 & 27 & 21 & 19 & 27 & 15 & 20 & 19 & 23 & 16 & 15 & 27 & 19 & 16 \\
\hline 1986 & 21 & 39 & 41 & 42 & 36 & 46 & 37 & 32 & 33 & 32 & 36 & 37 & 47 & 21 & 23 \\
\hline 1987 & 25 & 30 & 58 & 60 & 35 & 33 & 23 & 36 & 36 & 21 & 35 & 38 & 26 & 17 & 17 \\
\hline 1988 & 35 & 23 & 17 & 25 & 46 & 47 & 50 & 40 & 39 & 39 & 46 & 52 & 30 & 31 & 53 \\
\hline 1989 & 23 & 24 & 39 & 62 & 19 & 20 & 11 & 13 & 14 & 11 & 22 & 19 & 17 & 19 & 16 \\
\hline 1990 & 13 & 13 & 26 & 16 & 5 & 5 & 11 & 13 & 9 & 15 & 18 & 16 & 9 & 6 & 4 \\
\hline 1991 & 47 & 45 & 44 & 21 & 50 & 39 & 44 & 36 & 39 & 31 & 44 & 39 & 43 & 14 & 11 \\
\hline 1992 & 91 & 89 & 38 & 58 & 23 & 22 & 39 & 61 & 29 & 67 & 44 & 48 & 24 & 23 & 23 \\
\hline 1993 & 34 & 37 & 18 & 12 & 44 & 34 & 17 & 33 & 34 & 21 & 34 & 59 & 34 & 18 & 17 \\
\hline 1994 & 17 & 30 & 32 & 8 & 23 & 17 & 20 & 23 & 19 & 23 & 26 & 38 & 18 & 10 & 10 \\
\hline 1995 & 34 & 33 & 22 & 7 & 45 & 61 & 15 & 32 & 35 & 41 & 49 & 45 & 41 & 18 & 7 \\
\hline 1996 & 7 & 6 & NO & 0 & 73 & 60 & 6 & 10 & 10 & 55 & 16 & 9 & 7 & 4 & 6 \\
\hline 1997 & 13 & 10 & 9 & 0 & 20 & 15 & 4 & 15 & 15 & 14 & 15 & 14 & 16 & 1 & 1 \\
\hline 1998 & 17 & 16 & 14 & 2 & 27 & 29 & 24 & 11 & 19 & 20 & 24 & 22 & 24 & 13 & 22 \\
\hline 1999 & 89 & 89 & 52 & 65 & 123 & 45 & 47 & 57 & 32 & 34 & 51 & 60 & 76 & 46 & 34 \\
\hline 2000 & 28 & 43 & 47 & 14 & 127 & 36 & 37 & 21 & 22 & 30 & 20 & 27 & 21 & 41 & 29 \\
\hline 2001 & 19 & 19 & 19 & 39 & 17 & 19 & 15 & 19 & 19 & 16 & 19 & 18 & 20 & 18 & 22 \\
\hline 2002 & 58 & 59 & 86 & 99 & 70 & 56 & 24 & 56 & 70 & 19 & 60 & 71 & 72 & 31 & 46 \\
\hline 2003 & 9 & 18 & 13 & 10 & 14 & 15 & 20 & 16 & 15 & 19 & 20 & 19 & 18 & 14 & 14 \\
\hline 2004 & 17 & 6 & 1 & 1 & 6 & 10 & 3 & 7 & 7 & 5 & 21 & 15 & 10 & 9 & 10 \\
\hline 2005 & 18 & 17 & 15 & 14 & 24 & 25 & 22 & 25 & 24 & 22 & 25 & 28 & 27 & 17 & 17 \\
\hline 2006 & 22 & 33 & 38 & 37 & 45 & 32 & 21 & 46 & 45 & 16 & 27 & 33 & 27 & 14 & 26 \\
\hline 2007 & 23 & 27 & 38 & 19 & 22 & 21 & 38 & 14 & 17 & 24 & 23 & 22 & 17 & 26 & 23 \\
\hline 2008 & 37 & 24 & 24 & 34 & 37 & 41 & 2 & 23 & 23 & 23 & 33 & 33 & 54 & 22 & 23 \\
\hline 2009 & 43 & 40 & 35 & 70 & 83 & 87 & 24 & 31 & 33 & 45 & 64 & 66 & 97 & 25 & 14 \\
\hline 2010 & 34 & 32 & 53 & 31 & 18 & 17 & 23 & 22 & 29 & 23 & 29 & 31 & 19 & 7 & 7 \\
\hline 2011 & 26 & 28 & 34 & 34 & 16 & 11 & 18 & 24 & 24 & 18 & 30 & 52 & 18 & 14 & 20 \\
\hline \multicolumn{16}{|c|}{ Annual summary, water years 1930-2011: } \\
\hline Maximum & 177 & 159 & 166 & 143 & 135 & 132 & 101 & 106 & 130 & 203 & 141 & 177 & 116 & 174 & 108 \\
\hline 25 th percentile & 45 & 45 & 47 & 45 & 45 & 46 & 38 & 39 & 36 & 37 & 44 & 47 & 41 & 41 & 36 \\
\hline Median & 30 & 30 & 33 & 26 & 29 & 32 & 25 & 24 & 26 & 26 & 29 & 33 & 27 & 23 & 23 \\
\hline 75th percentile & 17 & 19 & 18 & 15 & 19 & 19 & 18 & 18 & 19 & 19 & 20 & 19 & 17 & 17 & 14 \\
\hline Minimum & 3 & 3 & 0 & 0 & 5 & 5 & 2 & 5 & 7 & 5 & 6 & 7 & 0 & 1 & 0 \\
\hline
\end{tabular}




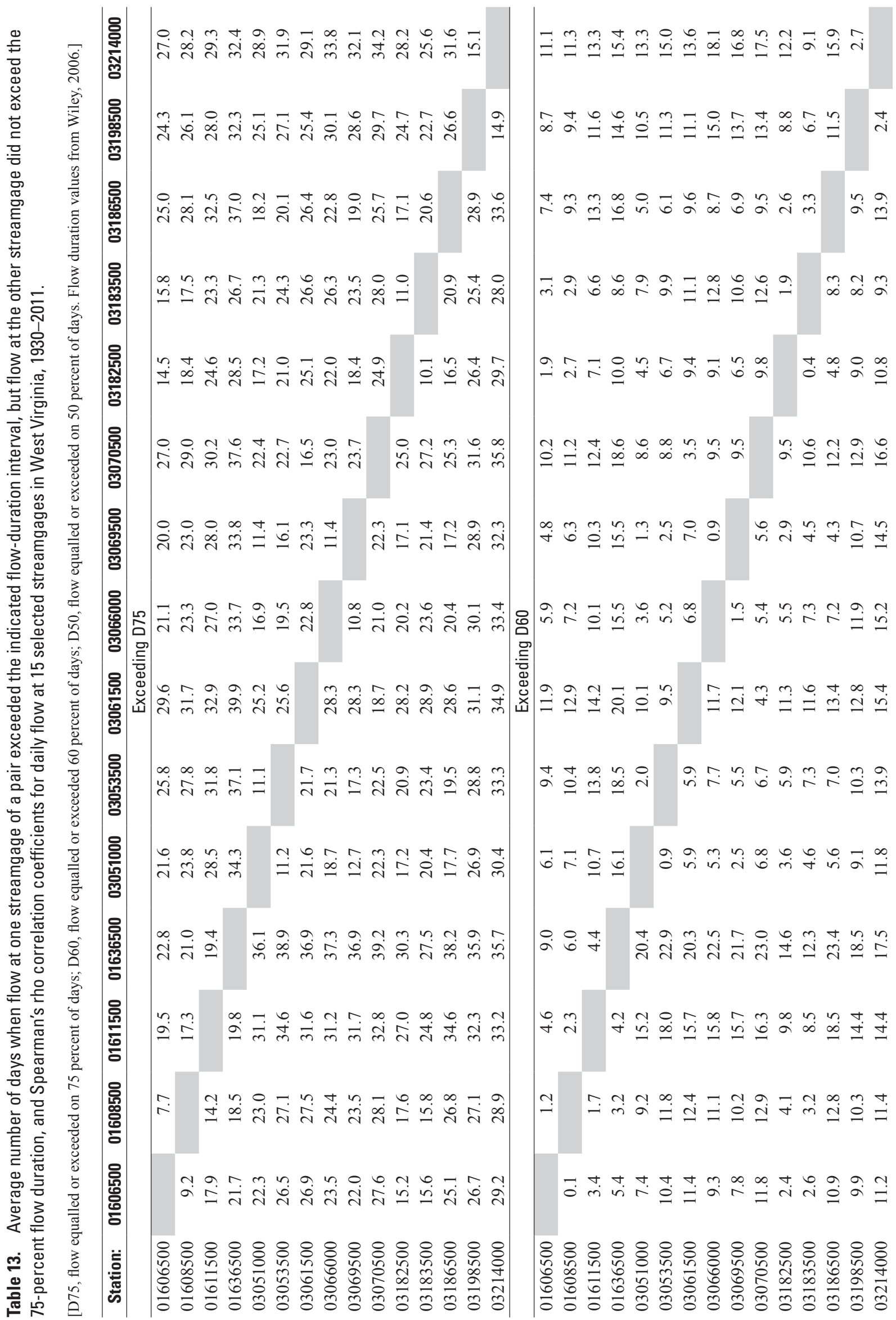




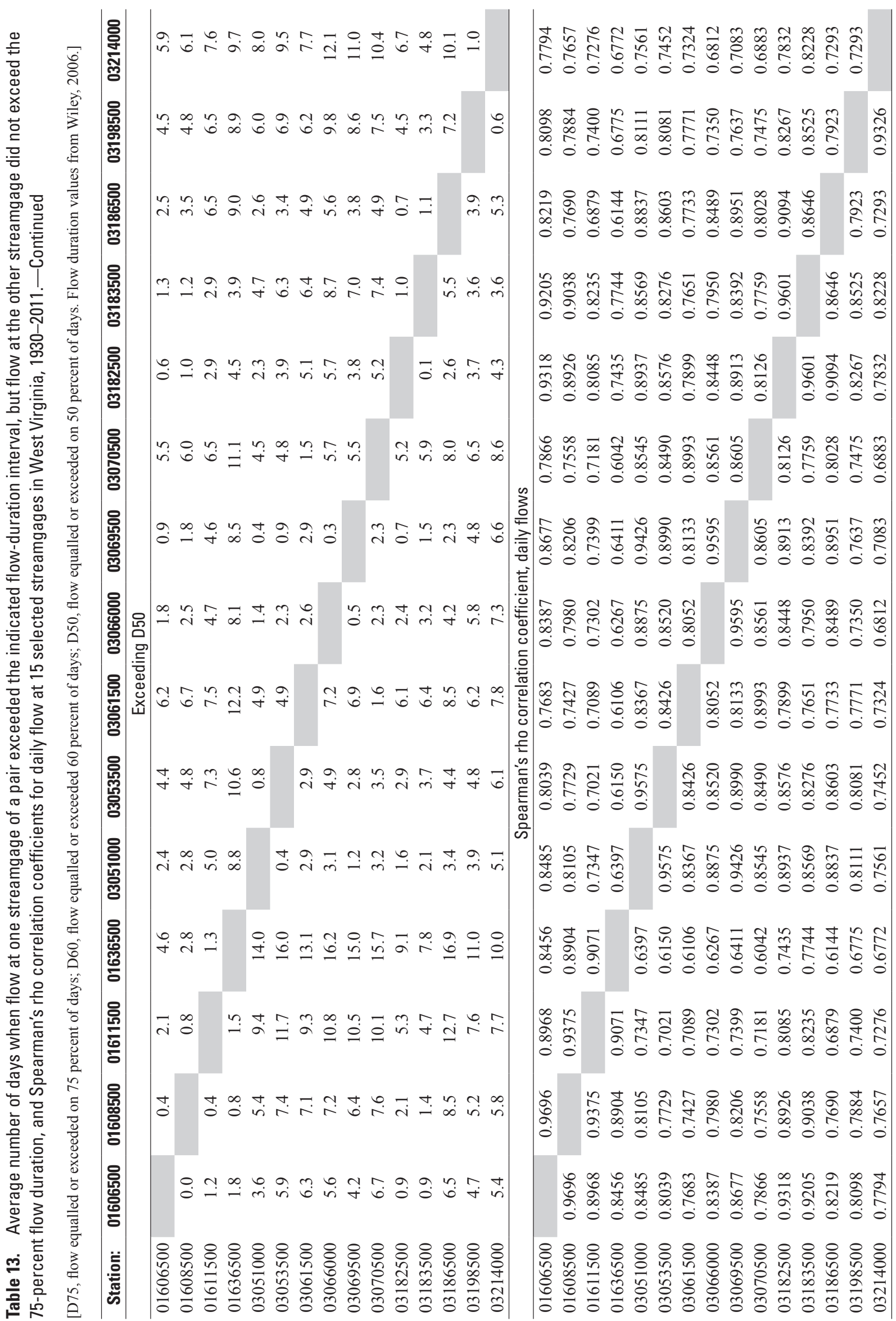




\section{Appendixes 1-8}

ArcGIS geodatabases containing rasters depicting correlations between daily flows at unregulated streamgages in and near West Virginia, 1930-2011, available at: $h t t p: / / d x . d o i . o r g / 10.3133 /$ sir20145061

Appendix 1. Flow correlation at all unregulated streamgages for full years, 1930-2011.

Appendix 2. Flow correlation at all unregulated streamgages for fall months only, 1930-2011.

Appendix 3. Flow correlation at all unregulated streamgages for winter months only, 1930-2011.

Appendix 4. Flow correlation at all unregulated streamgages for spring months only, 1930-2011.

Appendix 5. Flow correlation at all unregulated streamgages for summer months only, 1930-2011.

Appendix 6. Flow correlation at all unregulated streamgages for full years, 1963-1969.

Appendix 7. Flow correlation at all unregulated streamgages for full years, 1970-1979.

Appendix 8. Flow correlation at all unregulated streamgages for full years, 1992-2011. 

For additional information call or write to:

Director, U.S. Geological Survey

West Virginia Water Science Center

11 Dunbar Street, Charleston, WV 25301

(304) 347-5130

http://wv.usgs.gov 


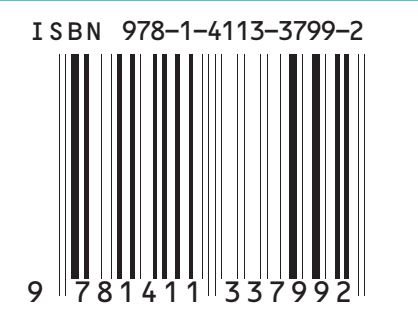

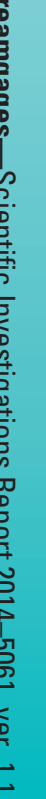

